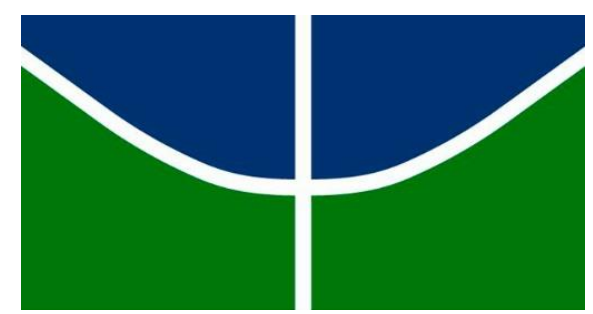

Universidade de Brasília

Instituto de Ciências Biológicas

Departamento de Botânica

CARACTERIZAÇÃO MORFOANATÔMICA E BIOQUÍMICA DA GERMINAÇÃO, SISTEMAS DE CONSERVAÇÃO EX SITU E INDUÇÃO DE CALOS PARA A EMBRIOGÊNESE SOMÁTICA DE PINHÃO-MANSO (Jatropha curcas L.)

JAQUELINE MARTINS VASCONCELOS 


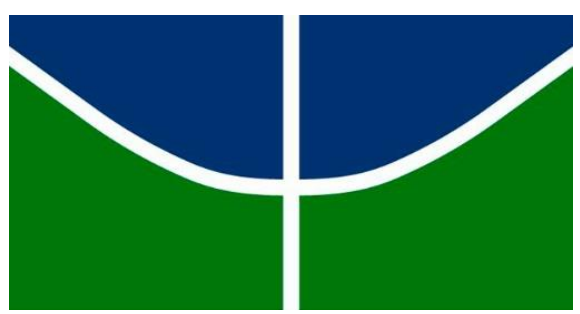

Universidade de Brasília

Instituto de Ciências Biológicas

Departamento de Botânica

\title{
CARACTERIZAÇÃO MORFOANATÔMICA E BIOQUÍMICA DA GERMINAÇÃO, SISTEMAS DE CONSERVAÇÃO EX SITU E INDUÇÃO DE CALOS PARA A EMBRIOGÊNESE SOMÁTICA DE PINHÃO-MANSO (Jatropha curcas L.)
}

\author{
JAQUELINE MARTINS VASCONCELOS
}

Orientador: Jonny Everson Scherwinski-Pereira

Tese apresentada ao programa de PósGraduação em Botânica do Instituto de Ciências Biológicas da Universidade de Brasília, para a obtenção do título de Doutora em Botânica. 
Ofereço

Aos meus pais,

Sebastião Carvalho Vasconcelos e Onilda Martins Vasconceos.

Ao meu irmão,

Sebastião Carvalho Vasconcelos Filho

Ao orientador e amigo,

Jonny Everson Scherwinski-Pereira

Dedico

A todos que me fortaleceram durante esta caminhada 


\section{AGRADECIMENTOS}

\section{A Deus;}

A minha família, sem não seria nada;

Aos amigos que sempre me apoiaram, em suas diferentes formas;

Aos professores e toda a equipe do Programa de Pós-Graduação em Botânica;

A toda família do Laboratório de Cultura de Tecidos II da EMBRAPA

\section{CENARGEN;}

A Coordenação de Aperfeiçoamento de Pessoal de Nível Superior (CAPES), pela concessão de recursos financeiros indispensáveis à realização deste trabalho de pesquisa.

Enfim, a todos aqueles implícitos acima, que fiz questão de não citar nomes, pois não queria cometer a indelicadeza do esquecimento de nenhum destes que me ensinaram grande parte do que sei e me fizeram ser a pessoa que sou hoje.

Muito obrigada! 


\section{SUMÁRIO}

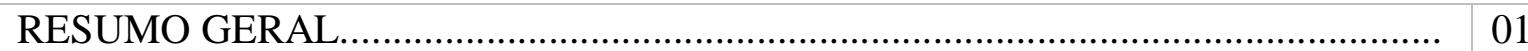

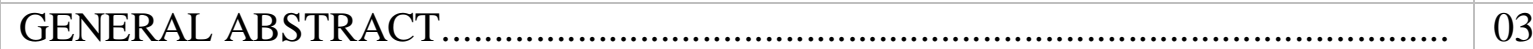

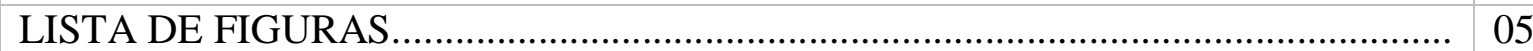

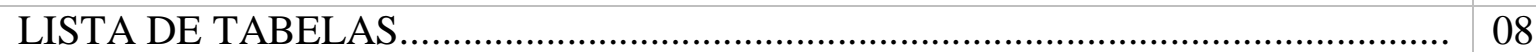

LISTA DE SÍMBOLOS E ABREVIATURAS ......................................................... 10

INTRODUÇÃO GERAL .................................................................................. 11

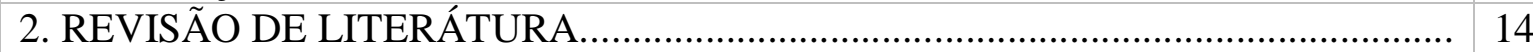

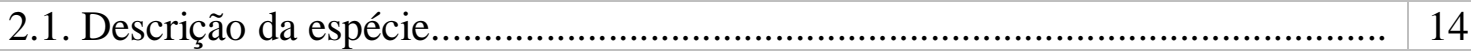

2.2. Importância econômica................................................................................... 17

2.3. Propagação da espécie....................................................................................... 19

2.4. A conservação ex situ por temperaturas subzero e criogênicas............................. 22

3. REFERÊNCIAS BIBLIOGRAFICAS............................................................... 26

\section{CAPÍTULO 1}

CARACTERIZAÇÃO MORFOANATÔMICA, HISTOQUÍMICA E BIOQUÍMICA DA GERMINAÇÃO E DO DESENVOLVIMENTO DE PLÂNTULAS DE Jatropha curcas L.

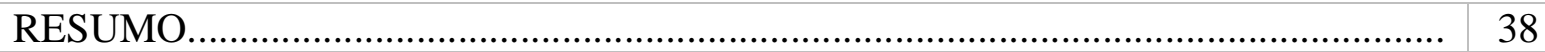

ABSTRACT .................................................................................................... 39

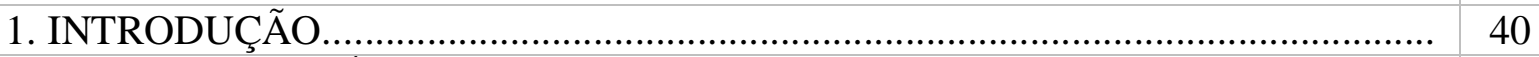

2. MATERIAL E MÉTODOS ............................................................................... 42

2.1. Local dos experimentos e material vegetal utilizado........................................... 42

2.2. Caracterização biométrica das sementes.................................................................. 42

2.3. Análise morfoanatômica, histoquímica e bioquímica da germinação e do desenvolvimento de plântulas in vitro........................................................................ 43

2.3.1. Caracterização morfológica ............................................................... 43

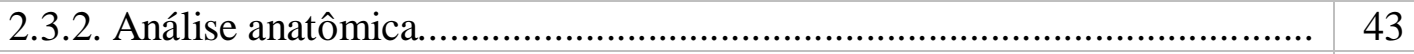

2.3.4. Análise histoquímica................................................................................... 44

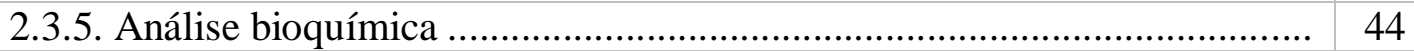

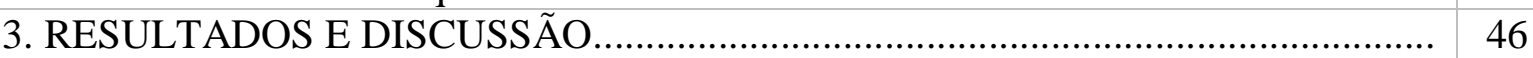

3.1. Caracterização biométrica das sementes.......................................................... 47

3.2. Análise morfoanatômica, histoquímica e bioquímica da germinação e do \begin{tabular}{|l|l} 
desenvolvimentode plântulas de pinhão-manso..... & 47
\end{tabular}

\begin{tabular}{|l|l} 
3.2.1. Caracterização morfológica...... & 47
\end{tabular}

\begin{tabular}{l|l} 
3.2.2. Análises anatômicas ................... & 48
\end{tabular}

\begin{tabular}{|l|l} 
3.2.3. Análises histoquímicas .............. & 51 \\
\hline
\end{tabular}

3.2.4. Análise bioquímica da germinação e pós germinação in vitro.................... 56

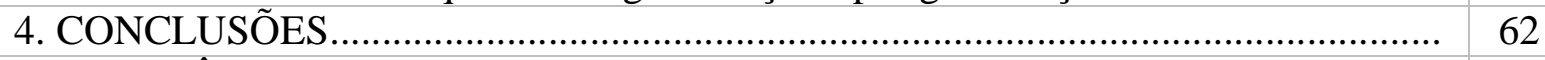

5. REFERÊNCIAS BIBLIOGRAFICAS ................................................................. 63

CAPÍTULO 2

COMPORTAMENTO INTERMEDIÁRIO PARA SEMENTES DE PINHÃOMANSO: UMA NOVA CLASSIFICAÇÃO QUE PODE INFLUENCIAR OS MÉTODOS DE CONSERVAÇÃO EX SITU DA ESPÉCIE 


\begin{tabular}{|c|c|}
\hline ABSTRACT. & 69 \\
\hline 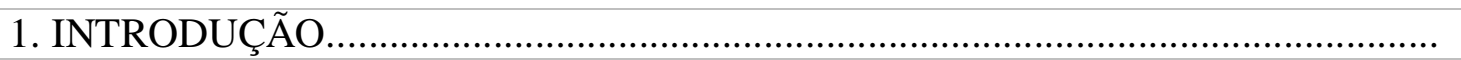 & 70 \\
\hline 2. MATERIAL E MÉTODOS. & 65 \\
\hline 2.1. Local dos experimentos e material vegetal utilizado........................... & 65 \\
\hline 2.2. Conservação a longo prazo de sementes de pinhão-manso.................................... & 65 \\
\hline 2.2.1. Determinação do grau de umidade inicial das sementes............................. & 65 \\
\hline 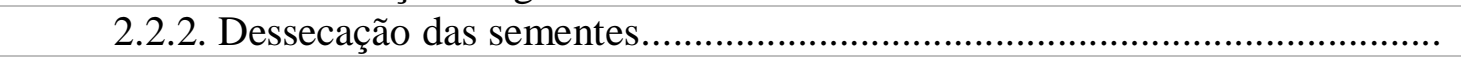 & 65 \\
\hline 2.2.3. Armazen & 66 \\
\hline 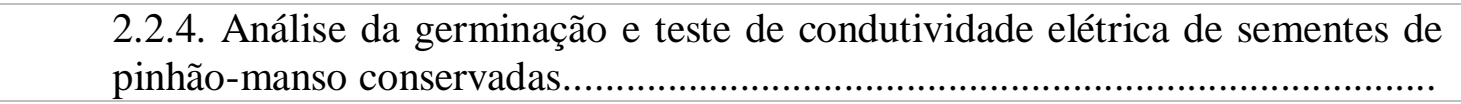 & 66 \\
\hline 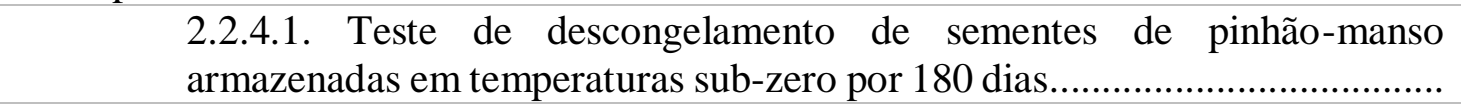 & 66 \\
\hline 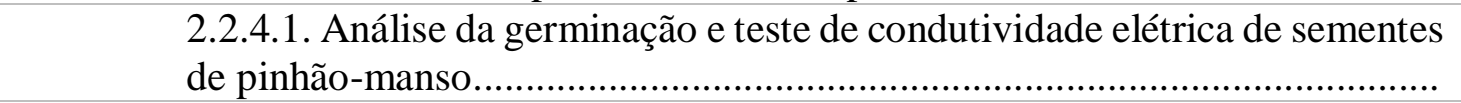 & 67 \\
\hline 2.2.5. Delineamento experimental..... & 67 \\
\hline 2.3. Criopreservação de eixos embrionários de pinhão & 68 \\
\hline 2.3.1. Determinação da umidade inicial dos eixos embrionários... & 68 \\
\hline 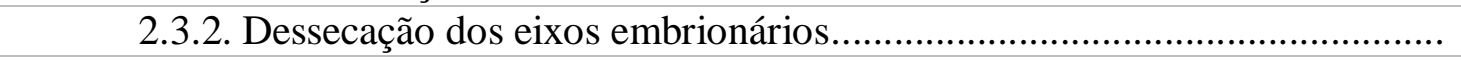 & 69 \\
\hline 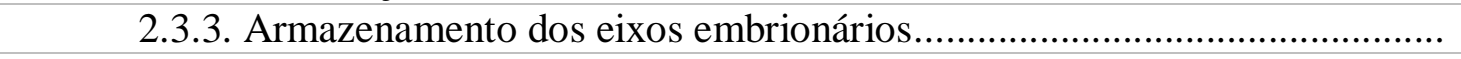 & 69 \\
\hline nários criopreservados.................. & 69 \\
\hline 2.3.5. Deline & 70 \\
\hline 2.4. Análise es & 70 \\
\hline 3. RESULTADOS E & 71 \\
\hline 3.1. Conservaça & 71 \\
\hline 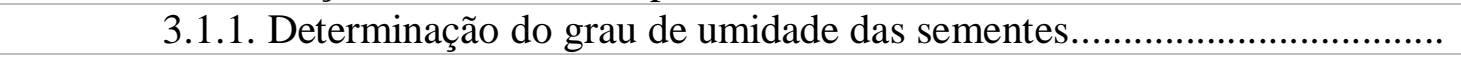 & 71 \\
\hline inhão-manso armazenadas & 72 \\
\hline $\begin{array}{l}\text { 3.1.3 Análise da germinação e teste de condutividade elétrica de sementes de } \\
\text { pinhão-manso }\end{array}$ & 73 \\
\hline 3.1.3.1. & 73 \\
\hline 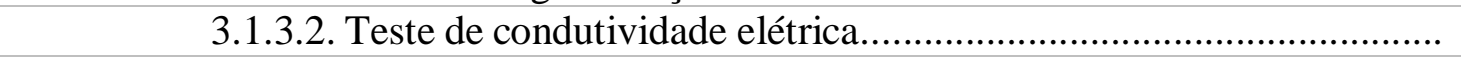 & 77 \\
\hline tanso............................... & 78 \\
\hline 3.2.1. Deter & 78 \\
\hline ICLUSÕES. & 82 \\
\hline 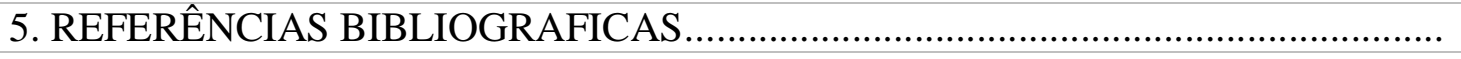 & 83 \\
\hline \multicolumn{2}{|l|}{ CAPÍTULO 3} \\
\hline \multicolumn{2}{|l|}{$\begin{array}{c}\text { INDUÇÃO E CARACTERIZAÇÃO MORFOANATÔMICA DE CALOS PARA O } \\
\text { DESENVOLVIMENTO DA EMBRIOGÊNESE SOMÁTICA EM PINHÃO-MANSO } \\
\text { (Jatropha curcas L.) }\end{array}$} \\
\hline RESUMO........ & 89 \\
\hline ABSTRACT. & 90 \\
\hline 1. INTRODUÇÃO. & 91 \\
\hline 2. MATERIAL E MÉTC & 93 \\
\hline 2.1. Local da realização dos experimentos. & 93 \\
\hline 2.2. Obtenção de $\mathrm{p}$ & 93 \\
\hline $\begin{array}{l}\text { 2.3. Indução de calos em explante } \\
\text { to-manso }\end{array}$ & 05 \\
\hline
\end{tabular}


2.4. Caracterização morfológica e anatômica de calos formados em hipocótilos

e folhas cotiledonares de pinhão-manso

2.5. Análises estatísticas................................................................................... 94

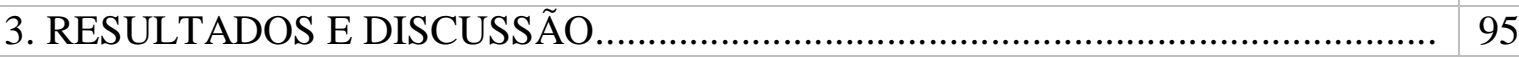

\begin{tabular}{l|l} 
3.1. Indução de calos em hipocótilos e folhas cotiledonáres de pinhão-manso ... & 95
\end{tabular}

3.2. Caracterização morfológica e anatômica de calos formados em hipocótilos e folhas cotiledonares de pinhão-manso ..................................................... 98

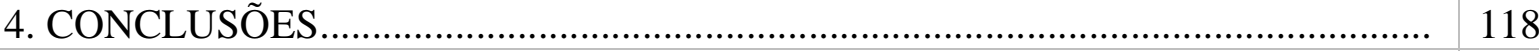

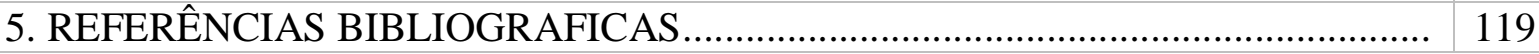




\section{RESUMO GERAL}

O presente trabalho teve por objetivo caracterizar bioquímica e histoquimicamente a germinação, desenvolver estratégias para a conservação de germoplasma, bem como induzir e caracterizar a calogênese in vitro de pinhão-manso visando o desenvolvimento de protocolos para a embriogênese somática. Para os estudos de germinação, as sementes foram desinfestadas, inoculadas in vitro e mantidas na presença de luz. As avaliações de desenvolvimento e as coletas para as análises morfoanatomicas, histoquímicas e bioquímicas da germinação foram realizadas ao longo do período de cultivo de 30 dias. A caracterização anatômica foi realizada com o auxílio do corante Azul de Toluidina e para as análises histoquímicas foram utilizados Sudan IV, para compostos lipídicos, Xylidine Ponceau, para proteínas totais e Reagente de Schiff/ ácido periódico - PAS, para polissacarídeos neutros. Para as análises bioquímicas, os materiais oriundos dos diferentes períodos de germinação foram avaliados quanto a percentagem de açucares solúveis totais (AST) e amido via método colorimétrico, de proteínas em aparelho CNS, além da quantificação de lipídios via técnica de derivatização in situ em GC-MS. Anatomicamente, as sementes apresentaram endosperma com células isodiamétricas, paredes delgadas e conteúdo celular visível em formas de gotas de lipídeos e corpos proteicos; os cotilédones e folhas com epiderme simples e mesofilo composto por parênquima paliçádico e lacunoso e o hipocótilo com cilindro vascular do tipo eustelo. Histoquimicamente, evidenciou-se que os lipídeos e as proteínas aparecem como o principal material de reserva no endosperma. As análises bioquímicas confirmaram a maior presença de ácidos graxos em relação aos demais compostos de reserva no endosperma, principalmente os ácidos oleicos e linoleicos. Já com a formação da plantula, o amido apareceu como a principal composto de reserva. Para os estudos de conservação, verificou-se a umidade inicial das sementes e, em seguida, se realizou o processo de dessecação em sílicagel por 0, 24, 48, 96 e 192 horas. Após cada tempo de dessecação, a umidade foi novamente avaliada e as sementes armazenadas em diferentes condições de temperatura $\left(25^{\circ} \mathrm{C}, 6^{\circ} \mathrm{C}\right.$, $20^{\circ} \mathrm{C} \mathrm{e}-196^{\circ} \mathrm{C}$ ) por $0,180,360$ e 720 dias. Transcorrido o tempo de conservação, as sementes foram germinadas in vitro e a germinação avaliada após 30 dias de cultivo. Análises de condutividade elétrica foram realizadas nas sementes armazenadas em todos os tratamentos. Para a criopreservação de eixos embrionários, inicialmente realizou-se a extração dos eixos em condições assépticas e a hidratação dos mesmos por 1 hora em placa de petri contendo papel filtro umedecido com água destilada estéril. Posteriormente, aplicou-se os tempos de dessecação pela exposição dos eixos ao fluxo de ar da câmara de fluxo laminar por 0, 2, 4, 6, 8 e 10 horas. Logo após os tempos de dessecação, a umidade dos eixos embrionários foi aferida e estes foram imersos em nitrogênio líquido por 0, 2, 30, 90, 180 e 360 dias. Após o período de conservação, foi realizado o teste de germinação in vitro, com avaliação após 30 dias de cultivo. As sementes de pinhão-manso toleraram a dessecação e se mantiveram viáveis com até $4,3 \%$ de umidade. Porém, não toleraram o armazenamento por período de até 720 dias em todas as temperaturas avaliadas, o que sugere um comportamento intermediário das sementes. O teste de condutividade elétrica foi eficaz na avaliação da qualidade das sementes, apresentando alta correlação entre a quantidade de íons observados e a percentagem de germinação. Com relação a criopreservação dos eixos embrionários, verificou-se uma taxa média de 90\% de germinação, após 360 dias de armazenamento, quando estes apresentavam umidade em torno de $8 \%$, e foi considerado a melhor técnica de conservação a longo prazo desta espécie. Por fim, explantes de hipocótilo e folhas cotiledonares de plantas cultivadas in vitro foram induzidos a calogênese em meio de MS suplementado com 2,4-D e picloram ( 0 , $50,100,200$ e $400 \mu \mathrm{M})$ em combinação ou não com $50 \mu \mathrm{M}$ de cinetina, sendo mantidos em condição de luz ou escuro por 30 e 60 dias. Após os tempos foi avaliado a percentagem de formação de calos, textura dos calos (friável, semi-compacto e compacto), além da coloração 
predominante. Amostras de calos com 60 dias de cultivo foram incluídas em metacrilato e caracterizados anatomicamente. Explantes de pinhão-manso, constituídos por hipocótilo e folhas cotiledonares foram responsivos a indução de calos, apresentando $100 \%$ de explantes com calos em vários tratamentos, principalmente na presença de picloram. $\mathrm{O}$ tratamento contento apenas cinetina promoveu a formação de calos friáveis em folhas cotiledonares e calos friáveis e semi-compactos em explantes de hipocótilo. O 2,4-D foi mais eficiente na formação de calos compactos com aspecto globular, enquanto o picloram induziu de calos semi-compactos e friáveis e de grande volume. Calos embriogênicos foram observados em hipocótilos e folhas cotiledonares cultivados com 200 e $400 \mu \mathrm{M}$ de picloram e 2,4-D, preferencialmente, no escuro. $\mathrm{O}$ presente trabalho contribuiu com informações relevantes sobre a caracterização da germinação de sementes de pinhão-manso. Esclareceu e determinou a melhor técnica de conservação ex situ para a espécie, sugerindo a mudança da classificação das sementes de ortodoxas para intermediarias. E no estudo de calos, propiciou várias informações a respeito da calogênese em pinhão-manso que servirão de subsídios para futuros trabalhos de embriogênese somática para a espécie.

Palavras-chave: Pinhão-manso, cultivo in vitro, germinação, bioquímica, conservação ex situ, calogênese. 


\section{GENERAL ABSTRACT}

This study aimed to characterize biochemical and histochemically germination, develop strategies for the conservation of germplasm, as well as induce and characterize the callus formation in vitro Jatropha for the development of protocols for somatic embryogenesis. For germination studies, the seeds were sterilized, inoculated in vitro and maintained in the presence of light. Development assessments and collections for morphoanatomic analysis, histochemical and biochemical germination were carried out during the 30-day culture period. The anatomical characterization was performed with the aid Blue stain and Toluidine for histochemical analyzes was used Sudan IV to lipid compounds, Xylidine ponceau to total protein and Schiff reagent / periodic acid - SAP for neutral polysaccharides. For the biochemical analyzes, the materials from the different periods of germination was evaluated as the percentage of total soluble sugars (AST) and starch via colorimetric method for proteins in the CNS device, and quantifying lipids via derivatization in situ GC MS. Anatomically, the seeds presented endosperm with isodiametrical cells, thin walls and visible mobile content forms droplets of lipid and protein bodies; cotyledons and leaves with simple epidermis and mesophyll consisting of palisade and spongy parenchyma and hypocotyl with vascular eustele type cylinder. Histochemically, it was shown that lipids and proteins appear as the main reserve material in the endosperm. Biochemical analyzes confirmed the increased presence of fatty acids in relation to other reserve compounds in the endosperm, especially oleic and linoleic acids. Since the formation of seedling, starch appeared as the primary reserve compound. For conservation studies, it was the initial seed moisture, and then held the desiccation process silica gel for 0 , 24, 48, 96 and 192 hours. After each time of drying, the humidity was again evaluated and the seeds stored at different temperature conditions $\left(25^{\circ} \mathrm{C}, 6^{\circ} \mathrm{C},-20^{\circ} \mathrm{C}\right.$ and $\left.-196^{\circ} \mathrm{C}\right)$ for 0,180 , 360 and 720 days. Elapsed time of conservation, the seeds were germinated in vitro and germination evaluated after 30 days of cultivation. electrical conductivity analyzes were performed on seeds stored in all treatments. For cryopreservation embryonic axes initially held extracting the axles under aseptic conditions and hydration thereof for 1 hour in petri dishes containing filter paper moistened with sterile distilled water. Subsequently, he applied to the drying times for exposing the axes of airflow of the laminar flow chamber for 0, 2, 4, 6, 8 and 10 hours. Soon after the drying time, moisture from the embryonic axis was measured and these were immersed in liquid nitrogen for 0, 2, 30, 90, 180 and 360 days. After the retention period, in vitro germination test was performed, with evaluation after 30 days of cultivation. The Jatropha seeds tolerate desiccation and remained viable up to $4.3 \%$ moisture. However, they not tolerate storage for a period up to 720 days all temperatures measured, which suggests an intermediate behavior seeds. The electrical conductivity test was effective in assessing the quality of seeds, with high correlation between the amount of ions observed and the percentage of germination. Regarding the cryopreservation of embryonic axes, there was an average $90 \%$ germination, after 360 days of storage when they had moisture around $8 \%$, and was considered the best long-term preservation technique of this kind. Finally, hypocotyl and cotyledon explants of leaves from plants grown in vitro were induced to callus induction on MS medium supplemented with 2,4-D and Picloram $(0,50,100,200$ and $400 \mathrm{mM})$ in combination with or without 50 uM kinetin, being kept in light or dark condition for 30 and 60 days. After time was evaluated the percentage of callus formation, callus texture (crumbly, semi-compact and compact), and the predominant color. Samples of corns with 60 days of culture were included in methacrylate and characterized anatomically. Jatropha explant consisting of hypocotyl and cotyledons were responsive to callus induction, with $100 \%$ of explants with calluses on various treatments, especially in the presence of picloram. Treatment satisfaction only kinetin promoted the formation of friable callus in cotyledons and friable calluses and semi-compact in hypocotyl 
explants. The 2,4-D was more efficient in the formation of compact callus with a globular appearance as picloram induced semi-compact callus and friable and large volume. embryogenic calli were observed in hypocotyls and cotyledons cultured with 200 to $400 \mathrm{mM}$ of picloram and 2,4-D, preferably in the dark. This work contributed with relevant information on the characterization of Jatropha seed germination. He clarified and determined the best ex situ conservation technique for the species, suggesting the change of the classification of orthodox seeds to intermediate. And the study of calluses, led various information about the callogenesis in Jatropha which will serve as subsidies for future work on somatic embryogenesis for the species

Keywords: Jatropha, in vitro cultivation, germination, biochemistry, ex situ conservation, callogenesis 


\section{LISTA DE FIGURAS}

\section{REVISÃO DE LITERATURA}

Figura 1: Centro de origem e distribuição geográfica de Jatropha curcas L................ 15

Figura 2: Órgãos vegetativos e reprodutivos de pinhão-manso.................................... 16

\section{CAPÍTULO 1}

Figura 1: Aspecto morfológico da semente sem tegumento e plântula de pinhão-manso (Jatropha curcas $\mathrm{L}$ ) durante germinação in vitro.

Figura 2: Caracterização anatômica da semente, folhas cotiledonares, folhas, caule e raiz de plântulas de pinhão-manso (Jatropha curcas L.)

Figura 3: Análise histoquímica de sementes de pinhão-manso cultivadas por até 30 dias e coradas com Sudan IV evidenciando a presença de lipídios corados de vermelho no interior das células.

Figura 4: Análise histoquímica de sementes de pinhão-manso cultivadas por até 30 dias e coradas com Xylidine Ponceau evidenciando a presença de proteínas de reserva coradas de vermelho no interior das células.

Figura 5: Análise histoquímica de sementes e plântulas de pinhão-manso cultivadas por até 30 dias coradas com PAS evidenciando a presença de amido coradas de magenta no interior das células.

Figura 6: Percentagem de lipídios, proteínas amido e açúcares solúveis totais (AST) em relação a massa seca de endosperma (A) e plântulas (B) de pinhão-mando (Jatropha curcas L.) durante a e pós germinação

\section{CAPÍTULO 2}

Figura 1. Curva de dessecação de sementes de pinhão-manso (Jatropha curcas L.) em sílica gel em razão do tempo de dessecação.

Figura 2. Curva de umidade de eixos embrionários de pinhão-manso (Jatropha curcas L.) em resposta ao tempo de dessecação em câmara de fluxo laminar.

Figura 3: Germinação dos eixos embrionários de pinhão-manso (Jatropha curcas L.) com diferentes umidades durante o armazenamento por até 360 dias.

\section{CAPÍTULO 3}

Figura 1: Análise morfológica e anatômica de calos de pinhão-manso (Jatropha curcas L.) obtidos a partir de folhas cotiledonares e hipocótilos cultivados na luz ou no escuro em meio de MS, sem a presença de reguladores de crescimento (tratamento controle) 
Figura 2: Análise morfológica e anatômica de calos de pinhão-manso (Jatropha curcas L.) obtidos a partir de folhas cotiledonares e hipocótilos cultivados na luz ou no escuro, em meio de MS suplementado com $50 \mu \mathrm{M}$ de cinetina.

Figura 3: Análise morfológica e anatômica de calos de pinhão-manso (Jatropha curcas L.) obtidos a partir de folhas cotiledonares e hipocótilos cultivados na luz ou no escuro, em meio de MS suplementado com $50 \mu \mathrm{M}$ de 2,4-D..

Figura 4: Análise morfológica e anatômica de calos de pinhão-manso (Jatropha curcas L.) obtidos a partir de folhas cotiledonares e hipocótilos cultivados na luz ou no escuro em meio de MS, suplementado com $50 \mu \mathrm{M}$ de picloram.

Figura 5: Análise morfológica e anatômica de calos de pinhão-manso (Jatropha curcas L.) obtidos a partir de folhas cotiledonares e hipocótilos cultivados na luz ou no escuro em meio de MS, suplementado com $50 \mu \mathrm{M}$ de 2,4-D e 50 $\mu \mathrm{M}$ de cinetina.

Figura 6: Análise morfológica e anatômica de calos de pinhão-manso (Jatropha curcas L.) obtidos a partir de folhas cotiledonares e hipocótilos cultivados na luz ou no escuro em meio de MS, suplementado com $50 \mu \mathrm{M}$ de picloram e 50 $\mu \mathrm{M}$ de cinetina.

Figura 7: Análise morfológica e anatômica de calos de pinhão-manso (Jatropha curcas L.) obtidos a partir de folhas cotiledonares e hipocótilos cultivados na luz ou no escuro em meio de MS, suplementado com $100 \mu \mathrm{M}$ de 2,4-D.

Figura 8: Análise morfológica e anatômica de calos de pinhão-manso (Jatropha curcas L.) obtidos a partir de folhas cotiledonares e hipocótilos cultivados na luz ou no escuro em meio de MS, suplementado com $100 \mu \mathrm{M}$ de picloram.

Figura 9: Análise morfológica e anatômica de calos de pinhão-manso (Jatropha curcas L.) obtidos a partir de folhas cotiledonares e hipocótilos cultivados na luz ou no escuro em meio de MS, suplementado com $100 \mu \mathrm{M}$ de 2,4-D e 50 $\mu \mathrm{M}$ de cinetina.

Figura 10: Análise morfológica e anatômica de calos de pinhão-manso (Jatropha curcas L.) obtidos a partir de folhas cotiledonares e hipocótilos cultivados na luz ou no escuro em meio de MS, suplementado com $100 \mu \mathrm{M}$ de Picloram e $50 \mu \mathrm{M}$ de cinetina.

Figura 11: Análise morfológica e anatômica de calos de pinhão-manso (Jatropha curcas L.) obtidos a partir de folhas cotiledonares e hipocótilos cultivados na luz ou no escuro em meio de MS, suplementado com $200 \mu \mathrm{M}$ de 2,4-D.

Figura 12: Análise morfológica e anatômica de calos de pinhão-manso (Jatropha curcas L.) obtidos a partir de folhas cotiledonares e hipocótilos cultivados na luz ou no escuro em meio de MS, suplementado com $200 \mu \mathrm{M}$ de picloram....... 
Figura 13: Análise morfológica e anatômica de calos de pinhão-manso (Jatropha curcas L.) obtidos a partir de folhas cotiledonares e hipocótilos cultivados na luz ou no escuro em meio de MS, suplementado com $200 \mu \mathrm{M}$ de 2,4-D e 50 $\mu \mathrm{M}$ de cinetina.

Figura 14: Análise morfológica e anatômica de calos de pinhão-manso (Jatropha curcas L.) obtidos a partir de folhas cotiledonares e hipocótilos cultivados na luz ou no escuro em meio de MS, suplementado com $200 \mu \mathrm{M}$ de picloram e $50 \mu \mathrm{M}$ de cinetina.

Figura 15: Análise morfológica e anatômica de calos de pinhão-manso (Jatropha curcas L.) obtidos a partir de folhas cotiledonares e hipocótilos cultivados na luz ou no escuro em meio de MS, suplementado com $400 \mu \mathrm{M}$ de 2,4-D

Figura 16: Análise morfológica e anatômica de calos de pinhão-manso (Jatropha curcas L.) obtidos a partir de folhas cotiledonares e hipocótilos cultivados na luz ou no escuro em meio de MS, suplementado com $400 \mu \mathrm{M}$ de picloram

Figura 17: Análise morfológica e anatômica de calos de pinhão-manso (Jatropha curcas L.) obtidos a partir de folhas cotiledonares e hipocótilos cultivados na luz ou no escuro em meio de MS, suplementado com $400 \mu \mathrm{M}$ de 2,4-D e 50 $\mu \mathrm{M}$ de cinetina.

Figura 18: Análise morfológica e anatômica de calos de pinhão-manso (Jatropha curcas L.) obtidos a partir de folhas cotiledonares e hipocótilos cultivados na luz ou no escuro em meio de MS, suplementado com $400 \mu \mathrm{M}$ de picloram e $50 \mu \mathrm{M}$ de cinetina. 


\section{LISTA DE TABELAS}

\section{CAPÍTULO 1}

Tabela 1: Caracterização biométrica de sementes de pinhão-manso (Jatropha cucas L.)

Tabela 2. Análise da presença ou ausência de lipídeos, proteínas e polissacarídeos totais em sementes, endosperma, folha cotiledonar, folha verdadeira, caule e raiz de plântulas de pinhão-manso (Jatropha curcas L.), durante a germinação de sementes in vitro.

Tabela 3. Alterações da composição de ácidos graxos (\%) em endosperma de pinhãomanso (Jatropha curcas L) durante o processo de germinação e pós germinação.

Tabela 4. Alterações da composição de ácidos graxos (\%) em plântulas de pinhãomanso (Jatropha curcas L) durante o processo de germinação e pós germinação.

\section{CAPÍTULO 2}

Tabela 1. Germinação de sementes de pinhão-manso (Jatropha curcas L) em função do teor de umidade em sementes

Tabela 2: Germinação de sementes de pinhão-manso (Jatropha curcas L.) em relação a temperatura de armazenamento, teor de umidade e tipo de descongelamento das sementes armazenadas por 180 dias

Tabela 3: Germinação de sementes de pinhão-manso (Jatropha curcas L.) em relação aos tempos, temperaturas de armazenamento e teor de umidade das sementes..

Tabela 4: Condutividade elétrica em sementes de pinhão-manso (Jatropha curcas L.) armazenadas com diferentes umidades e em diversas temperaturas por até 720 dias.

Tabela 5. Germinação de eixos embrionários de pinhão-manso (Jatropha curcas L) em função do teor de umidade.

\section{CAPÍTULO 3}

Tabela 1: Percentagem de hipocótilos de pinhão-manso (Jatropha curcas L.) com formação de calos quando cultivados em meio de MS, suplementado com 2,4D ou picloram em associação com cinetina, em condições de luz e escuro, após 30 e 60 dias

Tabela 2: Percentagem de folhas cotiledonares de pinhão-manso (Jatropha curcas L.) com formação de calos quando cultivados em meio de MS, suplementado com 
2,4-D ou picloram em associação com cinetina, em cultivos na luz e no escuro, após 30 e 60 dias. 


\section{LISTA DE SÍMBOLOS E ABREVIATURAS}

$\begin{array}{ll}\mu \mathbf{M} & \text { Micromolar } \\ \boldsymbol{\mu g} & \text { Micrograma } \\ \mathbf{m g} & \text { Miligramas (unidade de medida de massa) } \\ \mathbf{m L} & \text { Mililitro (unidade de medida de volume) } \\ \mathbf{g} & \text { Grama (unidade de medida de massa } \\ \mathbf{h} & \text { Hora (unidade de tempo) } \\ \mathbf{\text { o }} & \text { Graus Celsius } \\ \mathbf{N L} & \text { Nitrogênio liquido } \\ \text { et al. } & \text { Ácido 2,4-diclorofenoxiacético } \\ \text { 2,4-D } & \text { Ácido 3,6-dicloro-2metoxybenzoico } \\ \text { Dicamba } & \text { Expressão latina que significa "e outros" } \\ & \end{array}$




\section{INTRODUÇÃO GERAL}

Os combustíveis fósseis representam cerca de $93 \%$ do consumo primário de energia no mundo, especialmente, óleo (35\%), carvão (29\%) e gás natural (29\%). A energia nuclear e a gerada por hidroelétricas somam apenas 5 e $7 \%$ do total de energia consumida, respectivamente (FINLEY, 2013). É evidente que tanto as reservas quanto o consumo serão incrementadas, mas as previsões indicam que as reservas crescerão menos ao longo desse período. Além disso, apesar de atualmente os combustíveis fósseis serem a fonte de energia mais utilizada pela sociedade, sua combustão libera uma grande quantidade de $\mathrm{CO}_{2}$, o que contribui, para o aquecimento global (TOLMASQUIM, 2012; BRENNAN e OWENDE, 2013; DUARTE, 2014; DIAS e MATTOS, 2014)

Há diversas matrizes energéticas renováveis para a produção de energia em substituição aos derivados do petróleo, notadamente os biocombustíveis oriundos de produtos agrícolas, como a cana-de-açúcar, plantas oleaginosas, biomassa florestal e matéria orgânica (GOLDEMBERG, 2007 e MONTEIRO et al., 2015). O biodiesel é uma alternativa viável para o Brasil, uma vez que o país apresenta potencial para se tornar um dos maiores produtores do mundo, em razão da disponibilidade de áreas aptas ao plantio e clima adequado ao cultivo de oleaginosas (SATURNINO et al., 2005). Por ser biodegradável, o biodiesel é considerado um potencial substituto do diesel para motores ciclo diesel ou estacionários, sem necessidade de adaptações, em percentuais de até $20 \%$. É um produto conhecido principalmente na Europa desde o início do século XX, mas registros históricos relatam de seu uso desde o final do século XIX (VECCHIA, 2010).

Teoricamente, qualquer oleaginosa pode ser utilizada para a produção de biodiesel. Porém, devem-se considerar as vantagens de cada espécie, tais como a produtividade de óleo, robustez, custos de produção e de logística, capacidade de armazenamento, valor dos subprodutos, capacidade de geração de renda e nível tecnológico da cultura escolhida (SOARES, 2010).

De acordo com Silva e Freitas (2008), as principais culturas com potencial para produção de biodiesel incluem espécies como o dendê (Elaeis guineensis L.), côco (Cocos nucifera L.), babaçu (Attalea speciosa Mart.), girassol (Helianthus annus L.), canola (Brassica napus L.), mamona (Ricinus communis L.), amendoim (Arachis hypogea L.), soja [Glycine max (L.) Merril], algodão (Gossypum hirsutum L.) e o pinhão-manso (Jatropha curcas L.). Entretanto, para que essas espécies possam efetivamente serem utilizadas como produtoras de biodiesel é necessário empreender avanços em tecnologias agrícolas, que viabilizem a produção 
comercial de matérias primas de alta produtividade, principalmente para culturas ainda pouco estudas, como é o caso do pinhão-manso.

Neste contexto, nos últimos anos tem havido um grande interesse e, sobretudo, necessidade de se desenvolver tecnologias na área da cultura de células e tecidos de plantas em espécies com potencial energético, seja para a produção de mudas de genótipos de alguma importância agronômica em escala comercial ou para acelerar programas de melhoramento genético destas espécies. De acordo com Attaya et al. (2012), estudos mostram que o pinhãomanso é favorável para a propagação in vitro, os trabalhos envolvendo a multiplicação clonal da espécie via sistemas in vitro ainda são inssufcientes. Ainda segundo os autores, plantas de pinhão-manso oriundas desse tipo de cultivo podem apresentar maior rendimento e produtividade, quando comparadas com plantas obtidas por cultivo convencional via sementes.

De fato, diversos tipos de explantes já foram utilizados para trabalhos de pinhão-manso utilizando-se técnicas de cultura de tecidos de plantas, como: folhas (SUJATHA e MUKTA, 1996, SUJATHA e REDDY, 2000 e KAEWPOO e TE-CHATO, 2009), pecíolos (SUJATHA e MUKTA, 1996, SUJATHA e REDDY, 2000), caules (SUJATHA e REDDY, 2000 e KAEWPOO e TE-CHATO, 2009), cotilédones (KAEWPOO e TE-CHATO, 2009), epicótilos (WEI et al., 2004), hipocótilos (SUJATHA e MUKTA, 1996, SUJATHA e REDDY, 2000), segmentos nodais (RAJORE et al., 2002 e KAEWPOO e TE-CHATO, 2009), além de brotos apicais e axilares (SARDANA et al., 1998, RAJORE et al., 2002, THEPSAMRAN et al., 2008, KAEWPOO e TE-CHATO, 2009).

Como o cultivo de pinhão-manso vem sendo implantado em diversas regiões do Brasil, a maioria dos genótipos utilizados são ainda pouco conhecidos genética e agronomicamente, não existindo ainda cultivares melhoradas, sobre os quais se tenha informações relacionadas especialmente sobre o potencial de produção nas diferentes regiões produtoras (LAVIOLA et al., 2011). Por isso, para que se alcancem patamares mais elevados de produtividade em termos de quantidade de óleo por hectare, as pesquisas necessitam concentrar esforços para a seleção de materiais mais produtivos e adaptados para as diferentes regiões edafoclimáticas brasileiras. Como a variabilidade genética é um requisito fundamental à implementação e continuidade de programas de melhoramento genético, uma eficiente estratégia de conservação de germoplasma da espécie é essencial ao desenvolvimento de genótipos superiores e de importância comercial (SILVA et al., 2012).

Os recursos genéticos vegetais são uma fração da biodiversidade vegetal, com previsão atual ou potencial de uso, que representa uma fonte imensurável de variabilidade genética 
(FRALEIGH, 2006; SCHERWINSKI-PEREIRA e COSTA, 2010), além de ser uma das propriedades fundamentais da natureza responsável pelo equilíbrio e estabilidade dos ecossistemas, o que representa um imenso potencial de uso econômico.

Todavia, apesar da importância desses recursos, grande parte vem sendo destruída de modo irreversível, antes mesmo do seu pleno conhecimento científico. Assim, é importante a adoção de tecnologias destinadas à conservação de germoplasma que tenham como princípio básico, preservar o máximo possível da diversidade genética ou de indivíduos, visando seu uso atual e futuro como fonte de variabilidade (RAZDAN, 2003). Mas para que se alcance o máximo êxito em trabalhos de conservação e propagação de qualquer espécie vegetal, estudos básicos sobre a germinação e desenvolvimento inicial da planta, especialmente aos aspectos relacionados com a composição química e a fisiologia das sementes são fundamentais uma vez que estão estritamente relacionados com o potencial de armazenamento (CARVALHO e NAKAGAWA, 2000; PRADO, 2012).

Nesse contexto, o presente trabalho teve por objetivo caracterizar bioquímica e histoquimicamente a germinação, desenvolver estratégias para a conservação de germoplasma, bem como induzir e caracterizar a calogênese in vitro de pinhão-manso visando o desenvolvimento de protocolos para a embriogênese somática. 


\section{REVISÃO DE LITERATURA}

\subsection{Descrição da espécie}

A família Euphorbiaceae está representada nas regiões tropicais e temperadas de praticamente todo o planeta por um total de cerca de 8.000 espécies, distribuídas em 317 gêneros. Estes estão agrupados em 49 tribos e cinco subfamílias, segundo o sistema de classificação proposto por Webster (1994).

O gênero Jatropha se encontra entre os mais representativos da família (CRONQUIST, 1981). Recentemente, constatou-se que esse gênero contém, aproximadamente, 170 espécies distribuídas nas regiões tropicais e subtropicais da África e Américas, podendo as plantas deste gênero se apresentarem como ervas, arbustos ou árvores (KRISHNAN e PARAMATHMA, 2009).

No Brasil, o gênero Jatropha se encontra distribuído em todos os domínios fitogeográficos, sendo encontrados espécimes em quase todos os estados brasileiros (CORDEIRO e SECCO, 2012). Segundo os autores são encontrados 13 espécies e 4 variedades, sendo que das espécies, 6 são endêmicas.

A espécie J. curcas, popularmente conhecida por pinhão-manso, purgante ou mandiuguaçú, recebeu a designação cientifica em 1753 por Linnaeus, de acordo com a nomenclatura binomial em Species Platarum, sendo essa designação válida até os dias de hoje. A designação científica do gênero Jatropha deriva do grego "iatrós" (o doutor) e "trophé" (comida), o que sugere sua utilização na medicina; o epíteto específico curcas é a designação vulgar da purgueira em Malabar, Índia (HELLER, 1996)

Existe uma extensa lista de sinonímias para essa espécie, tendo sido reconhecida por Dehgan e Webster (1979): Curcas purgans Medil., Ricinus americanus Miller., Castiglionia lobata Ruiz e Pavon., Jatropha edulis Cerv. Gaz. Lit. Mex., J. Acerifolia salisb., Ricinus jarak Thumb., Curcas adansoni Endl., Cursas indica A. Rich e Curcas curcas (L.) Britthon e Millisp.

A espécie $J$. curcas é diplóide com $2 \mathrm{n}=22$ cromossomos e o tamanho do seu genoma (416 Mb) é aproximadamente igual ao genoma do arroz (400 Mb) (CARVALHO et al., 2008).

Ainda hoje é controversa a origem do pinhão-manso. Para alguns autores, um possível centro de origem é no Estado do Ceará, no Brasil. Porém, vários outros autores relatam o México e parte da América Central como possível ponto de origem para espécie (WILBUR, 1954; MARTIN e MAYEUX, 1984; HELLER, 1996), com predominância natural de ocorrência em florestas das regiões litorâneas. 
Para Heller (1996) e Tominaga et al. (2007) é provável que o México e a América Central sejam o centro de origem do pinhão-manso, uma vez que há vestígios de índios que migraram da América do Norte para a América do Sul há mais de 10.000 anos a terem transportado do México até a Argentina, incluindo o Brasil. A partir de então, navegadores portugueses a teriam distribuído para países da África e Ásia, uma vez que não há vegetação espontânea nesses continentes, apenas sob forma cultivada (Figura 1).

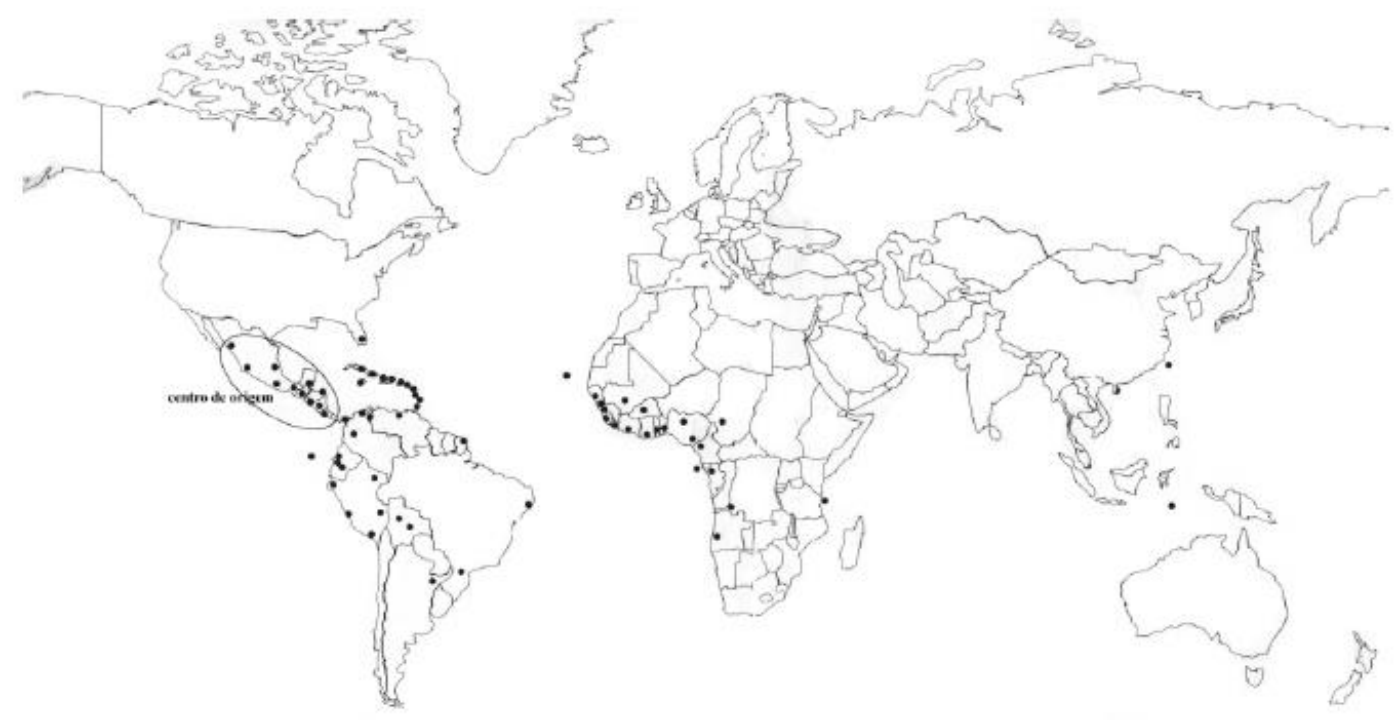

Figura 1: Centro de origem e distribuição geográfica de Jatropha curcas L. (Fonte: Heller, 1996).

J. curcas é um arbusto, de crescimento rápido, cuja altura normal é dois a três metros, mas pode alcançar até cinco metros em condições especiais. O diâmetro do tronco é de aproximadamente $20 \mathrm{~cm}$, com raízes curtas e pouco ramificadas, caule liso, de lenho mole e medula desenvolvida, mas pouco resistente. $\mathrm{O}$ tronco ou fuste é dividido desde a base, em compridos ramos, com numerosas cicatrizes produzidas pela queda das folhas na estação seca, as quais ressurgem logo após as primeiras chuvas. As folhas são verdes, esparsas e brilhantes, largas e alternas, em forma de palma com três a cinco lóbulos e pecioladas, com nervuras esbranquiçadas e salientes na face inferior. A espécie é monóica, apresentando na mesma planta, sexos separados. As flores masculinas, em maior número, se formam nas extremidades das ramificações, e as femininas ao longo das ramificações, as quais são amarelo-esverdeadas e diferenciam-se pela ausência de pedúnculo articulado nas femininas que são largamente pedunculadas (Figura 2) (HELLER, 2006 e DOMERGUE e PIROT, 2008).

A polinização da planta é entomófila e realizada preferencialmente por abelhas, formigas trips e moscas, sendo possível a realização da polinização artificial (JUHÁSZ et al. 
2009). O fruto é capsular ovóide, com diâmetro de 1,5 a 3,0 cm e trilocular, com uma semente em cada cavidade, formado por um pericarpo ou casca dura e lenhosa, indeiscente, inicialmente verde, passando a amarelo, castanho e por fim preto, quando atinge o estádio de maturação. O fruto apresenta peso variando entre 1,5 e $2,8 \mathrm{~g}$, sendo que cerca de 53 a $62 \%$ do peso do fruto equivale as sementes e de 38 a $47 \%$ a casca. As sementes quando secas medem entre 1,5 e $2 \mathrm{~cm}$ de comprimento e entre 1,0 e 1,3 cm de largura. O tegumento é rijo e quebradiço, de fratura resinosa. Debaixo do invólucro da semente existe uma película branca cobrindo a amêndoa, o albúmen é abundante, branco, oleaginoso, contendo o embrião provido de dois largos cotilédones (HELLER, 2006 e DOMERGUE e PIROT, 2008).

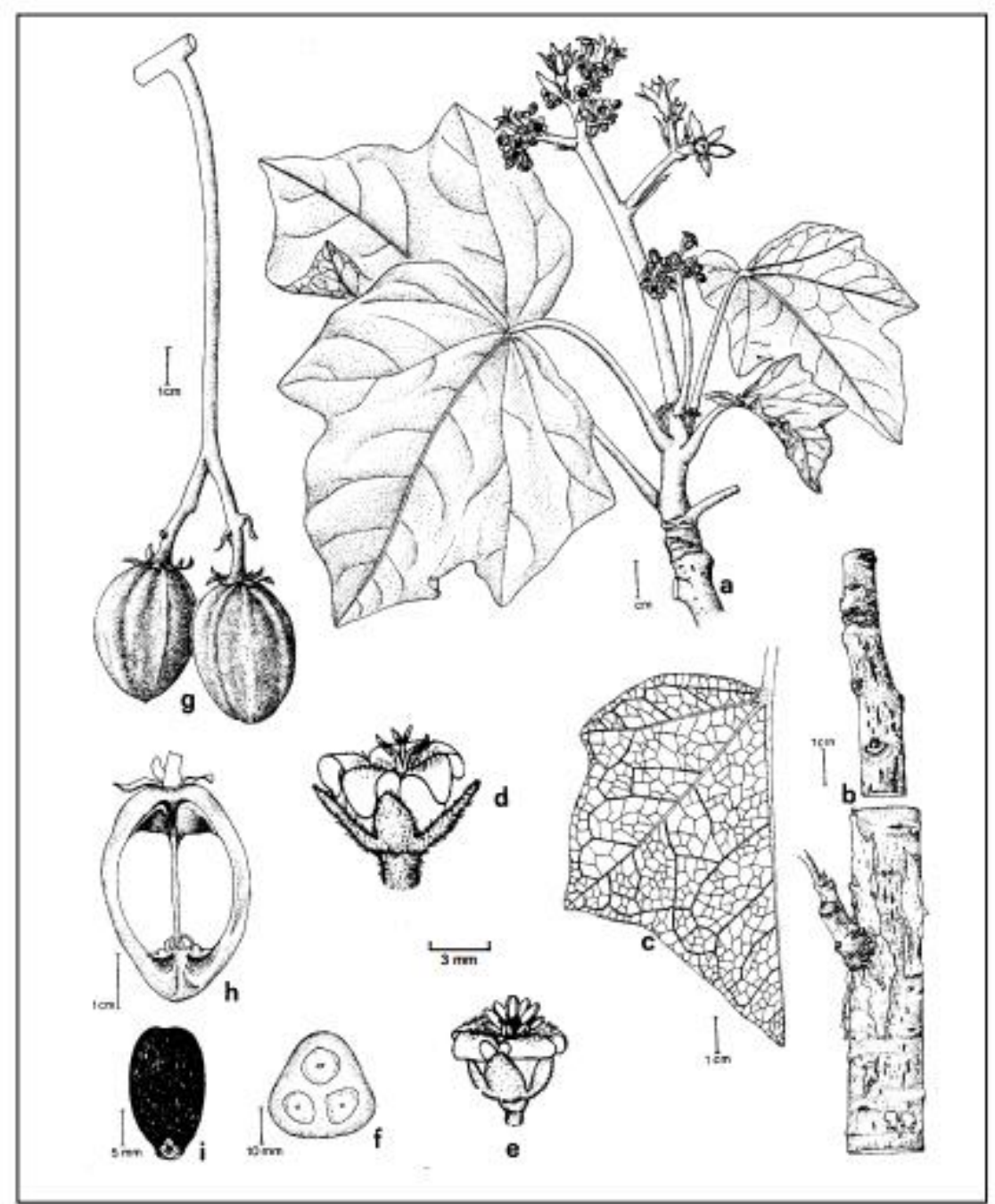

Figura 2: Órgãos vegetativos e reprodutivos de pinhão-manso: a - ramo florido, b- galho, cfolha, lado esquerdo, $\mathrm{d}$ - pistilo da flor, e - estame da flor, $\mathrm{f}$ - corte transversal no fruto imaturo, g- frutos, h- corte longitudinal nos frutos, i - semente. (Fonte: Heller, 1996). 


\subsection{Importância econômica}

Apesar de todas as vantagem e múltiplas utilidades do pinhão-manso já citadas, é fato que a espécie só se tornou mundialmente conhecida devido ao seu alto potencial na produção de biodiesel. Diversos trabalhos trazem informações sobre os programas de biodiesel a partir de pinhão-manso em diferentes países, como no Reino Unido (JANAUN e ELLIS, 2010), China (YE et al., 2009 e LIU et al., 2012), Malásia (LIM e TEONG, 2010 e KOH e GHAZI, 2011), Suécia (ARVIDSSON et al., 2011), Tailândia (SIRIWARDHANA et al., 2009), Indonésia (SILITONGA et al., 2011), Índia (BORA e BARUAH, 2012) e Brasil (ALVES et al., 2008).

No Brasil, o interesse na produção comercial de pinhão-manso ocorreu a partir da implantação do Plano Nacional de Produção de Biodiesel, o qual tem como expectativa atender a demanda por combustíveis de fontes renováveis, gerando empregos e renda na agricultura familiar, além de contribuir para a economia de divisas (BRASIL, 2007).

A espécie $J$. curcas L. é mundialmente conhecida como uma planta tropical com um potencial único para aumentar as fontes de energia renováveis (PANDEY et al., 2012), devido suas características peculiares, como tolerância a seca (OPENSHAW, 2000), crescimento rápido e facilidade de propagação. Além disso, apresenta de 30-37\% de teor de óleo em suas sementes (ACHTEN et al., 2008), mais do que outras culturas oleaginosas como o algodão (entre 14 e 25\%) (BELTRÃO, 2003) e na maioria das cultivares de soja (entre 15 e 25\%) (MOREIRA, 1999), mas, inferior ao rendimento de óleo do fruto ou semente inteira de girassol (entre 48 e 52\%) (FIRESTONE, 1999). Porém, essa pequena árvore é uma planta com muitos atributos de múltiplos usos e potencial considerável que vão além de sua utilização na produção de biodisel. Segundo Openshaw et al. (2000), por ser uma espécie bem adaptada a condições áridas e semiáridas e fácil de se estabelecer, atualmente o pinhão-manso se encontra distribuído em muitas partes do mundo, sendo cultivada na América Latina, África, Sudeste Asiático e na Índia, onde geralmente é cultivada como cerca viva. Seu cultivo requer tecnologias simples e baixo custo, sendo o rendimento das sementes variável entre 0,5 a 12 ton ano/ha, dependendo do solo, nutrientes, condições de chuva e genótipo (FRANCIS et al., 2005). As sementes contêm óleo que pode ser convertido a biodiesel de boa qualidade por transesterificação (FOIDL et al., 1996). Porém, o óleo de pinhão-manso é apenas um de uma série de produtos e subprodutos que esta espécie pode oferecer.

Tradicionalmente, tanto as sementes como outras partes da planta tem sido utilizada para a produção de óleo, sabão e compostos medicinais (KOHLI et al., 2009) e variedades não 
toxicas que vêm sendo exploradas no México na alimentação de animais (SCHMOOK et al., 1997, MAKKAR et al., 1998).

Além dessas atribuições, o pinhão-manso também vem sendo citado como uma espécie adequada para fitorremediação. Segundo Garbisu et al. (2002) e Alkorta et al. (2004), espécies fitorremediadoras devem apresentar crescimento rápido, alta produção de biomassa, sistema radicular abundante, tolerar condições adversas do meio ambiente, não ser comestíveis, além de serem economicamente benéficas. De acordo com Kaushik et al. (2007) e Gunaseelan (2009), o pinhão-manso apresenta baixa demanda por água, resistência a seca, crescimento rápido e exige pouca manutenção, atributos esses que classificam a espécie como apta para fitorremediação.

Estudos avaliando o potencial do pinhão-manso na fitorremediação relatam que a espécie foi capaz de extrair metais pesados a partir de cinzas volantes, sendo a capacidade de extração aumentada muitas vezes quando adicionado agentes quelantes como o EDTA (JAMIL et al., 2009). Juwarkar et al. (2008), Kumar et al. (2008), Mangkoedihardjo et al. (2008) e Yadav et al. (2009) também relataram que o pinhão-manso tem potencial para remediação de solos contaminados com $\mathrm{Al}, \mathrm{Fe}, \mathrm{Cr}, \mathrm{Mn}, \mathrm{Ar}, \mathrm{Zn}, \mathrm{Cd}$ e $\mathrm{Pb}$, além de apresentar potencial de bioacumulação. Agamuthu et al. (2010) o descrevem como fitorremediador de solos contaminados com hidrocarbonetos.

O sequestro de carbono no solo também vem sendo descrito como uma das atribuições do pinhão-manso (ROMIJN et al., 2011). Segundo El-Bassam (1998), tendo em vista as considerações ambientais, o biodiesel é considerado "carbono neutro", porque todo o $\mathrm{CO}_{2}$ liberado durante seu consumo é sequestrado da atmosfera durante o crescimento da planta, sendo assim uma energia limpa e renovável, que tem emissão zero de dióxido de carbono, provocando quase nenhuma poluição ao meio ambiente.

Além da produção de biodiesel, alimentação de animais, fitorremediação e sequestro de carbono, o cultivo de pinhão-manso também vem sendo atribuído no controle de erosão do solo. Segundo Reubens et al. (2011), o pinhão-manso desenvolve uma raiz principal profunda que estabiliza o solo contra deslizamentos de terra e as raízes laterais rasas previnem e controlam a erosão do solo causada pelo vento ou pela água, além de manter a umidade.

Assim, em diversos países a plantação de pinhão-manso tem diversos objetivos: em Mali, controle da erosão do solo e produção de biodiesel combinada (LUTZ, 1992), reflorestamento de áreas áridas e controle de erosão em Cabo Verde (SPAAK, 1990), além de 
planta de apoio para outras culturas, como a baunilha, em Madagascar e produção de biodiesel em áreas marginais na Índia (OGUNWOLE et al., 2008).

$\mathrm{Na}$ medicina, o pinhão-manso apresenta grande importância no uso humano e veterinário, sendo todas as partes da planta utilizadas (GOONASEKERA et al., 1995 e KAUSHIK et al., 2007). As sementes são utilizadas para tratar a gota, artrite e icterícia, cicatrização de feridas, fraturas e queimaduras (SAMY et al, 1998, ISAWUMI, 1978); o óleo de semente trata eczema, doenças de pele, reumatismo e tem ação purgativa (NATH e DUTTA, 1992); o caule é utilizado no tratamento de dor de dente, inflamação e sangramento (THOMAS, 1989); a seiva trata doenças dermatomucosas e o extrato vegetal ajuda na cicatrização de feridas, alergias, queimaduras, cortes e lepra (FOJAS et al., 1986); as folhas e látex combatem úlceras e contusões, além de reduzir o tempo de coagulação do sangue (OSONIYI e ONAJOBI, 2009; COELHO-FERREIRA, 2009); as raízes auxiliam no tratamento da inflamações (MUJUMDA e MISAR, 2009) e o fruto combate a dor de dente (COELHO-FERREIRA, 2009).

\subsection{Propagação da espécie}

Adaptada as condições edafoclimáticas das regiões brasileira e, principalmente ao Nordeste, o pinhão-manso encontra-se vegetando de forma asselvajada. No entanto, cientificamente, ainda se conhece muito pouco em relação às técnicas para a domesticação, cultivo e conservação da espécie (ARRUDA et. al., 2004; SATURNINO et al., 2005; BELTRÃO e CARTAXO, 2006 e ACHTEN et al., 2010). E, segundo Jongschaap et al. (2007), ainda são escassos os dados sobre a variabilidade genética, efeitos do ambiente e da interação genótipo-ambiente.

Conhecido por ter ampla adaptabilidade e multiplicidade de usos, o potencial do pinhãomanso ainda está longe de ser alcançado, pois variedades melhoradas e com características desejáveis para as condições de cultivo ainda não estão disponíveis para a comercialização (DIVAKARA et al. 2010). De acordo com Achten et al. (2010), por se tratar de um espécie ainda não-domesticada, são necessários estudos sobre a diversidade existente no germoplasma do pinhão-manso, que possibilitem o desenvolvimento de cultivares melhoradas. Assim, características como a toxicidade presente em suas sementes (ésteres de forbol), a floração assíncrona, bem como a desuniformidade de maturação e produção, também deve ser geneticamente melhorada para a exploração comercial da cultura (JOHNSON, ESWARAN e 
SUJATHA, 2011). Ademais, ao se estabelecer uma cultura de pinhão-manso, a taxa de sobrevivência pode ser influenciada pela escolha do método de cultivo (HELLER, 1996).

A espécie é propagada por via seminal e vegetativa (SATURNINO et al., 2005). Entretanto, plantios desuniformes com uso de sementes e a alta demanda de material vegetal (estacas) têm sido apontados como os principais fatores que limitam a expansão racional da cultura. Assim, pesquisas a respeito de multiplicação in vitro da espécie são imprescindíveis, seja para acelerar programas de melhoramento genético, produzir mudas de genótipos selecionados em escala comercial, ou então, permitir estudos biológicos básicos sobre a espécie (ACHTEN et al., 2010; MUKHERJEE et al., 2011).

Os principais métodos para a produção de mudas de pinhão-manso são por semeadura direta, plantio de mudas originadas de sementes ou por propagação assexuada (OPENSHAW, 2000). Em plantios comerciais de pinhão-manso, geralmente as mudas são oriundas de material de origem seminal (PANDEY et al., 2012). Entretanto, mudas de pinhão-manso produzidas por sementes apresentam variações quanto às características fenotípicas devido ao desenvolvimento da espécie em uma vasta gama de condições climáticas (GINWAL et al., 2005).

Segundo MUKHERJEE et al. (2011), uma das desvantagens da propagação convencional de pinhão-manso via sementes é a desuniformidade da produção e a influência dos fatores edáficos sobre a taxa de produção de sementes. Além do mais, por ser uma espécie que apresenta polinização cruzada, as sementes podem apresentar potencial genético desconhecido. Segundo SUJATHA et al. (2005), a propagação vegetativa da espécie também apresenta baixo rendimento, além das plantas propagadas desta formar serem suscetíveis ao ataque de insetos e doenças. Assim, o cultivo em grande escala de pinhão-manso continua sendo uma das questões mais importantes para o sucesso da cultura.

Para melhorar o rendimento da produção de pinhão-manso, algumas práticas agronômicas podem ser aplicadas. A clonagem de genótipos superiores, visando a multiplicação massal de germoplasma superior, via micropropagação é um exemplo (PANDEY et al., 2012). A partir dessa ferramenta biotecnológica, plantas com características de interesse podem ser introduzidas em larga escala, direcionando melhorias para a cultura, em termos de produtividade de grãos, teor de óleo, toxicidade da semente e resistência a pragas e doenças (ABHILASH et al., 2011).

A micropropagação pode ser definida como uma técnica de propagação vegetativa in vitro. Hartman et al. (1990) sugerem o termo micropropagação para designar o cultivo asséptico de pequenas partes da planta em condições controladas de nutrição, luminosidade, fotoperíodo 
e temperatura. É uma técnica utilizada principalmente para plantas que apresentam dificuldades de multiplicação pela reprodução natural e pelos métodos convencionais de propagação vegetativa, permitindo a obtenção de grande número de plantas sadias e geneticamente uniformes, em curto período de tempo (THORPE et al., 1991; XAVIER et al., 2007).

De fato, a cultura de tecidos de plantas tem sido citada como técnica promissora para a propagação de diversas espécies oleaginosas com potencial para produção de biodiesel, (PALMER e KELLER, 2011; LI et al., 2011; CHHIKARA et al., 2012; SURANTHRAN et al., 2013), sendo que para o gênero Jatropha, são também encontrados trabalhos de micropropagação, em especial para espécie $J$. curcas (KUMAR et al., 2010; DAUDET et al., 2011; LEELA et al., 2011; SHARMA et al., 2011; ATTAYA et al., 2012; TOPPO et al., 2012).

Protocolos de propagação in vitro de pinhão-manso têm sido citados para vários tipos de explantes (SHARMA, et al. 2011). Em 1998, Sujatha e Reddy mostraram que thidiazuron (TDZ) promoveu maior frequência de regeneração de brotos axilares quando comparado com benzilaminopurina (BAP). Em um estudo posterior, diferentes concentrações de cinetina $(\mathrm{Kn})$, BAP e TDZ foram testadas, seguido de subcultivo em meio contendo $2 \mathrm{mg} \mathrm{L}^{-1}$ de BAP (SUJATHA et al., 2005).

A multiplicação a partir de hipocótilos de diferentes genótipos, incluindo um genótipo não tóxico, e segmentos nodais foi desenvolvido satisfatoriamente por Sharma et al. (2011) e Datta et al. (2007), respectivamente. Além disso, Kumar et al. (2010) conseguiram regenerar plantas via organogênese direta por meio de explantes de pecíolo. Oliveira et al. (2013) descreveram a indução de poliploides in vitro a partir de variedades de pinhão-manso. Li et al. (2006) obtiveram regeneração adventícia a partir de segmentos hipotiledonares, cotilédones e folhas.

Thepsamran et al. (2008) demonstraram ser possível a regeneração de vários tipos de explantes como meristema apical, nós, brotos derivados de gema axilar, pecíolos e explantes foliares em meio de MS (MURASHIGE e SKOOG, 1962) suplementado com diferentes concentrações de BAP ou em combinação com ácido indolbutírico (AIB). Adicionalmente, vários autores têm relatado formação de gemas a partir de folhas e pecíolos em meio MS com a presença de reguladores de crescimento (SUJATHA e MUKTA, 1996; SUJATHA et al., 2005; SOOMRO e MEMON, 2007; DEORE e JOHNSON, 2008; THEPSAMRAN et al., 2008; KHURANA-KAUL et al, 2010; KUMAR e REDDY, 2010).

Entretanto, segundo Daudet et al. (2011), em J. curcas a regeneração adventícia é bastante reduzida. Os autores observaram que apenas as técnicas de propagação utilizando 
como explante gemas axilares e folhas apresentaram algum sucesso na regeneração de brotos, enquanto em explantes cotiledonares foi possível observar a formação de calos embriogênicos.

Toppo et al. (2012) desenvolveram um protocolo para a micropropagação de pinhãomanso com a adição de água de coco, favorecendo a produção de brotações contendo maior área foliar, aumentando também a taxa de enraizamento.

Quando embriões zigóticos provenientes de frutos imaturos foram cultivados in vitro, os mesmos necessitaram da suplementação de sacarose no meio de cultura para a germinação (NUNES et al., 2008). No cultivo in vitro de embriões de pinhão-manso, a sacarose na concentração de $30 \mathrm{gL}^{-1}$ mostrou-se eficiente para a promoção do alongamento da parte aérea e aumento do número de raízes (DIAS-LOPEZ et al., 2012). Na fase de aclimatização, com mudas produzidas a partir da micropropagação de segmentos nodais, observou-se até $87 \%$ de sobrevivência (DATTA et al., 2007) e, para plantas micropropagadas oriundas de hipocótilos, a sobrevivência foi de 90\% (SHARMA et al., 2011).

Apesar dos diversos trabalhos de micropropagação de pinhão-manso disponíveis na literatura, a regeneração in vitro desta espécie é genótipo-dependente e o número de brotações induzidas é influenciado pela posição e fonte de explantes (HORBACH et al., 2014). A idade do material vegetal também interfere no potencial de regeneração via organogênese direta, sendo que esta capacidade diminui com o tempo (SHARMA et al., 2011).

Dessa forma, as técnicas de micropropagação de pinhão-manso disponibilizadas na literatura ainda são insuficientes, devido aos protocolos não serem completamente dominados, necessitando, assim, de mais estudos para torná-los mais eficientes e aplicáveis, especialmente, os voltados para a embriogênese somática em que os trabalhos ainda são raramente citados, mas altamente estudados e ainda buscados cientificamente.

\subsection{A conservação ex situ por temperaturas subzero e criogênicas}

A conservação dos recursos fitogenéticos é obtida pela proteção das populações na natureza (in situ) ou pela preservação de amostras em bancos de germoplasma (ex situ) (HEYWOODA e IRIONDO, 2003, RAJPUROHIT e JHANG., 2015). Estes últimos são essenciais, pois garantem pronto acesso ao material quando necessário, atuando como um back up para determinados segmentos da diversidade que poderiam ser perdidos na natureza (HAWKES et al., 2012). 
Os bancos de germoplasma desempenham um papel vital na exploração, conservação e divulgação científica da diversidade genética vegetal, essencialmente necessário para o melhoramento de culturas para alimentação, saúde e segurança nutricional (FAO, 2014).

Segundo Cochrane et al. (2007), diversas são as justificativas para que uma espécie seja selecionada quanto a prioridade de conservação. Dentre elas se destacam espécies com baixos números de plantas, pertencentes a populações ou área geográfica limitada, ameaçadas pela atividade humana, susceptíveis a doença, salinidade, plantas invasoras ou pastagens, aqueles que experimentam um rápido declínio e geneticamente ou taxonomicamente diferente das espécies mais comuns, podem ter total prioridade para a conservação ex situ. Assim como habitats em risco imediato de destruição e, onde em ações in situ não podem garantir a sobrevivência das espécies, a manutenção ex situ do material vegetal torna-se necessário, agindo como um seguro e como fonte de material de reintrodução e reestabelecimento futuro (BARRETT et al., 1991).

Atualmente, existem mais de 1750 bancos de germoplasma para a conservação ex situ da diversidade de plantas no mundo, os quais detêm cerca de 7,5 milhões de acessos, sendo que $45 \%$ de todos os acessos dos bancos mundiais são de cereais, 15\% são de leguminosas, 9\% forrageiras, vegetais, nozes e frutas somam 13\%, raízes e tubérculos $3 \%$, oleaginosas $3 \%$, culturas de plantas têxteis $2 \%$, culturas de açúcar 1\%, e outros $8 \%$ (FAO, 2014).

O material vegetal para a conservação ex situ pode ser desde pólen, segmentos nodais, tecido ou cultura de células e sementes, sendo este último o propágulo mais eficiente e de relativamente baixo custo utilizado na conservação, pois além de ocuparem pouco espaço, as sementes podem produzir plantas inteiras, quando necessário, podendo ainda serem conservadas em diferentes formas e locais, diminuindo ainda mais o risco de extinção (ROBERTS, 1991).

Em bancos de germoplasma, a conservação em longo prazo é definida como o armazenamento de sementes de acessos de plantas por longos períodos, sendo o ambiente de armazenamento operado em temperaturas sub-zero. Entretanto, também deve-se levar em conta o grau de umidade das sementes a serem conservadas (em torno de 5\%), a utilização de embalagens herméticas e temperaturas iguais ou inferiores a $-18^{\circ} \mathrm{C}$ (HAY e ROBERT, 2013).

Para fins de conservação ex situ e viabilidade, as sementes podem ser classificadas como recalcitrantes (intolerantes a dessecação), ortodoxas (tolerantes a dessecação) (ROBERT, 1973) ou intermediárias (parcialmente tolerantes a dessecação, porém sensíveis a baixas temperaturas) (ELLIS e ROBERTS, 1990). 
A FAO (2014) recomenda a conservação ex situ de longo prazo de sementes de espécies ortodoxas com umidade abaixo de $7 \%$ e acondicionadas em recipientes à prova de umidade, tais como sacos de folha laminadas, latas de alumínio, ou frascos de vidro para armazenamento em baixa temperatura $\left(-18^{\circ} \mathrm{C}\right)$. Para as espécies selvagens, a temperatura de $4{ }^{\circ} \mathrm{C}$ e um teor de umidade entre $7-8 \%$ são as mais recomendadas. Sementes não ortodoxas não podem ser armazenadas com sucesso por longo prazo, utilizando protocolos convencionais (secagem e armazenagem a baixas temperaturas). Em vez disso, a criopreservação (geralmente em nitrogênio líquido, a -196 ${ }^{\circ} \mathrm{C}$ ) é o método de conservação mais recomendado (WALTERS et al., 2013).

A criopreservação é a conservação de organismos vivos em nitrogênio líquido à temperatura de $-196^{\circ} \mathrm{C}$ ou ligeiramente inferior, podendo esta fase constituir uma etapa intermediária para o congelamento definitivo a $-196^{\circ} \mathrm{C}$ (GROUT e CRISP, 1985; WITHERS, e ENGELMANN, 1998; WITHERS e WILLIAMS, 1990; WALTERS, 2015). Nessas temperaturas, o metabolismo celular e os processos bioquímicos são substancialmente reduzidos e a deterioração biológica é praticamente paralisada; conseqüentemente é mínima a deterioração biológica do material durante o armazenamento (KARTHA, 1985 e REED, 2008).

O uso de técnicas criogênicas ou criopreservação constitui uma alternativa para a conservação de germoplasma em longo prazo, principalmente quando a conservação convencional, baseada no armazenamento de sementes dessecadas em baixas temperaturas, não se mostra eficiente. Geralmente, sementes ortodoxas são secas até atingirem baixos níveis de teores de umidade e colocadas em câmaras frias a $-20^{\circ} \mathrm{C}$, o que é conhecido como armazenamento ou conservação convencional. Em contraste, as sementes recalcitrantes devem ser protegidas e armazenadas criogenicamente, em nitrogênio líquido (WALTERS et al., 2015).

O pinhão-manso, na maioria das vezes é propagado via sementes, as quais são caracterizadas como ortodoxas (DENG et al., 2008; SILVA et al., 2012), embora outros autores relatem perdas de até $50 \%$ de viabilidade após armazenamento de 15 meses (JOKER e JEPSEN, 2003; PRADA, et al., 2015).

Essa queda na taxa de germinação provavelmente se deve ao fato de que sementes oleaginosas, tais como as de pinhão-manso, são difíceis de se conservar por métodos convencionais, quando comparadas com sementes ricas em amido, devido à natureza lipídica de seus compostos de reserva. Os lipídeos como compostos majoritariamente de reserva são quimicamente instáveis, sendo a peroxidação dos lipídios uma das principais causas da deterioração deste tipo de semente, por promover mudanças no sistema de membranas e 
atividade biosintética; redução na velocidade de germinação e potencial de armazenagem das sementes (PEREIRA et al., 2013). Assim, estudos de armazenamento de sementes de pinhãomanso por longos períodos de tempo se tornam de suma importância.

Sem dúvida, a criopreservação é atualmente a técnica de conservação que mais tem sido buscada e para a qual tecnologias têm sido aprimoradas, promovendo certa diversificação dos métodos de criopreservação e permitindo ampliar seus usos (WITHERS e ENGELMANN, 1998 e WALTERS, 2015). No entanto, embora existam vários procedimentos criogênicos para um crescente número de espécies produtoras de sementes recalcitrantes e órgão/tecidos in vitro, o emprego rotineiro da criopreservação de sementes, em especial de J. curcas, ainda é considerado limitado (SILVA et al., 2012; GOLDFARB, et al, 2010 e PRADA, 2015) e deve ser melhor estudado para possibilitar a conservação segura de germoplasma da espécie. 


\section{REFERÊNCIAS BIBLIOGRAFICAS}

ABHILASH, P. C., SRIVASTAVA, P., JAMIL, S., e SINGH, N. Revisited Jatropha curcas as an oil plant of multiple benefits: critical research needs and prospects for the future. Environmental Science and Pollution Research, v. 18, n. 1, p. 127-131, 2011.

ACHTEN, W. M. J., VERCHOT, L., FRANKEN, Y. J., MATHIJS, E., SINGH, V. P., AERTS, R., e MUYS, B. Jatropha bio-diesel production and use. Biomass Bioenergy, v.32, p. 1063 84. 2008

ACHTEN, W. M., MAES, W., AERTS, R., VERCHOT, L., TRABUCCO, A., MATHIJS, E., e MUYS, B. Jatropha: from global hype to local opportunity. Journal of Arid Environments, v. 74, n. 1, p. 164-165, 2010.

AGAMUTHU, P., ABIOYE, O. P., e AZIZ, A. A. Phytoremediation of soil contaminated with used lubricating oil using Jatropha curcas. Journal of hazardous materials, v. 179, n. 1, p. 891-894, 2010.

ALKORTA, I., HERNÁNDEZ-ALLICA, J., BECERRIL, J. M., AMEZAGA, I., ALBIZU, I., e GARBISU, C. Recent findings on the phytoremediation of soils contaminated with environmentally toxic heavy metals and metalloids such as zinc, cadmium, lead, and arsenic.

Reviews in Environmental Science and Biotechnology, v. 3, n. 1, p. 71-90, 2004.

ALVES, J.M.A., SOUSA, A. A., SILVA, S.R.G., LOPES, G.N, SMILERLE, O.J. e UCHÔA, S.C.P. Pinhão-manso uma alternativa para produção de biodiesel na agricultura familiar da Amazônia brasileira. Agro@mbiente On-line, v. 2, 2008.

ARRUDA, F.P., BELTRÃO, N.E. De M., ANDRADE, A.P., PEREIRA, W.E. e SEVERINO, L.S. Cultivo de pinhão-manso (Jatropha curcas L.) como alternativa para o Semi-Árido nordestino. Revista Brasileira de Oleaginosas e Fibrosas, v.8, p. 789-799, 2004.

ARVIDSSON, R., PERSSON, S., FRÖLING, M., e SVANSTRÖM, M. Life cycle assessment of hydrotreated vegetable oil from rape, oil palm and Jatropha. Journal of Cleaner Production, v. 19, n. 2, p. 129-137, 2011.

ATTAYA, A.S., GEELEN, D. e BELAL, A.E.H. Progress in Jatropha curcas tissue culture. American-Eurasian Journal of Sustainable Agriculture, v. 6, n. 1, p. 6-13, 2012.

BARRETT, S. C., KOHN, J. R., FALK, D. A., e HOLSINGER, K. E. Genetic and evolutionary consequences of small population size in plants: implications for conservation. Genetics and conservation of rare plants. p. 3-30, 1991.

BELTRÃO, N.E.M. e CARTAXO, W.V. Considerações gerais sobre o pinhão-manso (Jatropha curcas L.) e a necessidade urgente de pesquisas, desenvolvimento e inovações tecnológicas para esta planta nas condições brasileiras. Embrapa Algodão, Campina GrandePB, n. 98, p. 4, 2006. 
BELTRÃO, NE de M. Breve história do algodão no nordeste do Brasil. Embrapa Algodão, 2003.

BORA, D. K., e BARUAH, D. C. Assessment of tree seed oil biodiesel: A comparative review based on biodiesel of a locally available tree seed. Renewable and Sustainable Energy Reviews, v. 16, n. 3, p. 1616-1629, 2012.

BRASIL, MINISTÉRIO DA AGRICULTURA E REFORMA AGRÁRIA. Cartilha. Biodiesel: o novo combustível do Brasil. Programa Nacional de Produção e Uso do Biodisel. Governo Federal, 2007.

BRENNAN, L e OWENDE, P. Biofuels from microalgae: towards meeting advanced fuel standards. In: Advanced biofuels and bioproducts. Springer New York, p. 553-599. 2013.

CARVALHO, C. R., CLARINDO, W. R., PRAÇA, M. M., ARAÚJO, F. S., e CARELS, N. Genome size, base composition and karyotype of Jatropha curcas L., an important biofuel plant. Plant Science, v. 174, n. 6, p. 613-617, 2008.

CARVALHO, C. M. D., MARINHO, A. B., VIANA, T. V. D. A., VALNIR JÚNIOR, M., SILVA, L. L., e GOMES FILHO, R. R. Production components of Jatropha under irrigation and nitrogen fertilization in the semiarid region of Ceará. Revista Brasileira de Engenharia Agrícola e Ambiental, v. 19, p. 871-876. 2015.

CARVALHO, N. M.; NAKAGAWA, J. Germinação de sementes. In: CARVALHO, N.M., NAKAGAWA, J. Sementes: ciência, tecnologia e produção. 4.ed. Jaboticabal: FUNEP, 2000. p. 128-166.

CHHIKARA, S., DUTTA, I., PAUlOSE, B., JAIWAL, P.K. e DHANKHER, O.P. Development of an Agrobacterium-mediated stable transformation method for industrial oilseed crop Crambe abyssinica 'BelAnn'. Industrial Crops and Products. v.37, p. 457-465, 2012.

COCHRANE, J. A.; CRAWFORD, A. D.; MONKS, L. T. The significance of ex situ seed conservation to reintroduction of threatened plants. Australian Journal of Botany, v. 55, n. 3, p. 356-361, 2007.

COELHO-FERREIRA, M. Medicinal knowledge and plant utilization in an Amazonian coastal community of Marudá, Pará State (Brazil). Journal of Ethnopharmacology, v. 126, n. 1, p. 159-175, 2009.

CORDEIRO, I. e SECCO, R. Jatropha in Lista de Espécies da Flora do Brasil. Jardim Botânico do Rio de Janeiro, 2012.

CRONQUIST, A. An integrated system of classification of floring plants. New York: Columbia University Press. 1981.

DATTA, M. M., MUKHERJEE, P., GHOSH, B., e JHA, T. B. In vitro clonal propagation of biodiesel plant (Jatropha curcas L.). Current Science, v. 93, p. 1438-42. 2007. 
DAUDET, M.M.S., MERGEAI, G., BAUDOIN, JP. e TOUSSAINT, A. Culture in vitro de Jatropha curcas L. Biotechnologie, Agronomie, Société et Environnement, v. 15, p.567, 2011.

DEHGAN, B. e WEBSTER, G. L. Morphology and infrageneric relationships of the genus Jatropha (Euphorbiaceae). University of California Publications in Botany. University of California Press, Berkeley, v. 74, 1979. 73p.

DENG, Z.J., XIANG, Z.Y., CHENG, H.Y., LI, Y.J. e SONG, S.Q. Preliminary study on development, germination and desiccation tolerance of Jatropha curcas (Euphorbiaceae). Acta Botanica Yunnanica, v. 30, n. 3, p. 355-359, 2008.

DEORE, A.C. e JOHNSON, T.S. High-frequency plant regeneration from leaf-disc cultures of Jatropha curcas L.: an important biodiesel plant. Plant Biotechnology Reports, v. 2, n. 1, p. 7-11, 2008.

DIAS, M.S. e MATTOS, J.R.L. Avaliação prospectiva da geração de energia elétrica no mundo e no Brasil. Centro de Desenvolvimento de Tecnologia Nuclear, p. 1-6. 2014.

DIAZ-LOPEZ, L., GIMENO, V., SIMÓN, I., MARTÍNEZ, V., RODRÍGUEZ-ORTEGA, W. M., e GARCÍA-SÁNCHEZ, F. Jatropha curcas seedlings show a water conservation strategy under drought conditions based on decreasing leaf growth and stomatal conductance. Agricultural water management, v. 105, p. 48-56, 2012.

DIVAKARA, B. N., UPADHYAYA, H. D., WANI, S. P., e GOWDA, C. L. Biology and genetic improvement of Jatropha curcas L.: a review. Applied Energy, v. 87, n. 3, p. 732-742, 2010.

DOMERGUE, M. e PIROT, R. Jatropha curcas L. Rapport de synthèse bibliographique, 2008.

DUARTE, R. S. M. Transição energética: as escolhas governamentais no Brasil e no mundo para o planejamento energético no contexto das mudanças climáticas e aquecimento global. Monografia. Universidade de Brasília. 2014.

El-BASSAM N. Energy plant species: their use and impact on environment and development. UK: James and James Science Publishers; 1998.

ELLIS, R. H., HONG, T. D. e ROBERTS, E. H. An intermediate category of seed storage behaviour? I. Coffee. Journal of Experimental Botany, v. 41, n. 9, p. 1167-1174, 1990.

FAO. Genebank Standards for Plant Genetic Resources for Food and Agriculture, 2014.

FINLEY, Mark. BP statistical review of world energy. BP technical report, 2013.

FIRESTONE, D. Physical and chemical characteristics of oils, fats, and waxes. Washington: AOCS, 152 p. 1999. 
FOIDL, N., FOIDL, G., SANCHEZ, M., MITTELBACH, M. e HACKEL, S. Jatropha curcas L. as a source for the production of biofuel in Nicaragua. Bioresource Technology, v. 58, n. 1, p. 77-82, 1996.

FOJAS, F. R., GARCIA, L. L., VENZON, E. L., SISON, F. M., VILLANEUVA, B. A., FOJAS, A. J., e LLAVE, I. Pharmacological studies on Jatropha curcas as a possible source of anti-arrhythmic (beta-blocker) agent Philippine J. Sci. 115. 317-328. En 14 refs Jatropha_curcas, Medicinal_plants, Tubang_bakod. Pharmacology, Euphorbiaceae, Cardiovascular_agents (EBBD, 190318507), 1986.

FRANCIS, G., EDINGER, R. e BECKER, K. A concept for simultaneous wasteland reclamation, fuel production, and socio-economic development in degraded areas in India: Need, potential and perspectives of Jatropha plantations. In: Natural Resources Forum. Blackwell Publishing, Ltd., 2005. p. 12-24..

GARBISU, C., HERNANDEZ-ALLICA, J., BARRUTIA, O., ALKORTA, I e BECERRIL, J.M. Phytoremediation: a technology using green plants to remove contaminants from polluted areas. Reviews on environmental health, v. 17, n. 3, p. 173-188, 2002.

GINWAL, H. S., PHARTYAL, S. S., RAWAT, P. S., e SRIVASTAVA, R. L. Seed source variation in morphology, germination and seedling growth of Jatropha curcas Linn. in central India. Silvae Genetica, v. 54, n. 2, p. 76-79, 2005.

GOLDEMBERG, J. Ethanol for a susteinable energy future. Science, v. 315, p. 808-810, 2007.

GOLDFARB, M., DUARTE, M.E.M. e MATA, M.E.R.M.C. Armazenamento criogênico de sementes de pinhão-manso (Jatropha curcas L.) Euphorbiaceae. Biotemas, v.23, p. 27-33, 2010.

GOONASEKERA, M.M., GUNAWARDANA, V. K., JAYASENA, K., MOHAMMED, S.G. e BALASUBRAMANIAM S. Pregnancy terminating effect of Jatropha curcas in rats. Journal of ethnopharmacology, v. 47, n. 3, p. 117-123, 1995.

GROUT, B.W.W. e CRISP, P. Germination as unreliable indicator of the effectiveness of cryopreservative procedures for imbibed seeds. Annals of Botany, v. 55, p.289-242, 1985.

GUNASEELAN, V.N. Biomass estimates, characteristics, biochemical methane potential, kinetics and energy flow from Jatropha curcus on dry lands. Biomass and Bioenergy, v. 33, n. 4, p. 589-596, 2009.

HARTMANN, H. T., KESTER, D. E. e DAVIES, F. T. Plant progation; principles and practices. New Jersey, USA. Prentice Hall. 647 p. 1990.

HAWKES, J. G., MAXTED, N., e FORD-LLOYD, B. V. The ex situ conservation of plant genetic resources. Springer Science e Business Media, 2012.

HAY, F. R., e PROBERT, R. J. Advances in seed conservation of wild plant species: a review of recent research. Conservation Physiology, v. 1, n. 1, p. cot030, 2013. 
HELLER, J. Physic nut. (Jatropha curcas L.) Promoting the conservation and use of underutilized and neglected crops 1. International Plant Genetic Resources Institute, Roma. 1996. $66 \mathrm{p}$.

HEYWOOD, Vernon H.; IRIONDO, Jose M. Plant conservation: old problems, new perspectives. Biological conservation, v. 113, n. 3, p. 321-335, 2003.

HORBACH, M. A., MALAVASI, U. C., DE MATOS MALAVASI, M., AJALA, M. C., LIMA, P. R., e SCHULZ, D. G. Propagation methods for physic nut (Jatropha curcas). Advances in Forestry Science, v. 1, n. 1, p. 53-57, 2014.

INSANU, M., DIMAKI, C., WILKINS, R., BROOKER, J., VAN DER LINDE, P., e KAYSER, O. Rational use of Jatropha curcas L. in food and medicine: from toxicity problems to safe applications. Phytochemistry reviews, v. 12, n. 1, p. 107-119, 2013.

ISAWUMI, M.A. Nigerian chewing sticks. Niger Field, v. 43, p. 111-21. 1978.

JAMIL, S., ABHILASH, P.C., SINGH, N. e SHARMA, P.N. Jatropha curcas: a potential crop for phytoremediation of coal fly ash. Journal of hazardous materials, v. 172, n. 1, p. 269-275, 2009.

JANAUN, J. e ELLIS, N. Perspectives on biodiesel as a sustainable fuel. Renewable and Sustainable Energy Reviews, v. 14, n. 4, p. 1312-1320, 2010.

JOHNSON, T.S., ESWARAN, N. e SUJATHA, M. Molecular approaches to improvement of Jatropha curcas Linn. as a sustainable energy crop. Plant cell reports, v. 30, n. 9, p. 15731591, 2011.

JOKER, D. e JEPSEN, J. Jatropha curcas. Seed leaflet, n. 83, 2003.

JONGSCHAAP, R. E. E., CORRÉ, W. J., BINDRABAN, P. S. e BRANDENBURG, W. A. Claims and Facts on Jatropha curcas L. 2007.

JUHÁSZ, A.C.P., PIMENTA, S., SOARES, B.O., MORAES, D.L.B. e RABELO, H.O. Biologia floral e polinização artificial de pinhão-manso no norte de Minas Gerais. Pesquisa Agropecuaria Brasileira. V. 44, p. 1073-1077, 2009.

JUWARKAR, A.A, YADAV, S.K, KUMAR, P. e SINGH, S.K. Effect of biosludge and biofertilizer amendment on growth of Jatropha curcas in heavy metal contaminated soils. Environmental monitoring and assessment, v. 145, n. 1-3, p. 7-15, 2008.

KAEWPOO, M.S. e TE-CHATO. M. Influence of explants types and plant growth regulators on multiple shoot formation from Jatropha curcas. Science. Asia. v.35, p. 353-357, 2009.

KARTHA, K.K. Meristem culture and germplasm preservation. In: Kartha, K.K. (Ed.) Cryopreservation of plant cells and organs. Boca Raton, Florida, CRC Press, pp. 115-134. 1985. 
KAUSHIK, N., KUMAR, K., KUMAR, S., KAUSHIK, N. e RAY, S. Genetic variability and divergence studies in seed traits and oil content of Jatropha (Jatropha curcas L.) accessions. Biomass and Bioenergy, v. 31, n. 7, p. 497-502, 2007

KHURANA-KAUL, V., KACHHWAHA, S. e KOTHARI, S. L. Direct shoot regeneration from leaf explants of Jatropha curcas in response to thidiazuron and high copper contents in the medium. Biologia plantarum, v. 54, n. 2, p. 369-372, 2010.

KOH, M.Y. e GHAZI, T.I. M. A review of biodiesel production from Jatropha curcas L. oil. Renewable and Sustainable Energy Reviews, v. 15, n. 5, p. 2240-2251, 2011.

KOHLIS, A., POPLUECHAI, RAORANE, M, SYERS, K.J. e O'DONNELL, A. G. Jatropha curcas as a novel, non-edible oilseed plant for biodiesel. Environmental Impact of Genetically Modified Crops, p. 296, 2009.

KRISHNAN, P. R., e PARAMATHMA., M. Potentials and Jatropha species wealth of India. Scientific Correspondence, v. 97, p. 1000-1004, 2009.

KUMAR, G. P., YADAV, S. K., THAWALE, P.R., SINGH, S.K. e JUWARKAR, A. A. Growth of Jatropha curcas on heavy metal contaminated soil amended with industrial wastes and Azotobacter-A greenhouse study. Bioresource Technology, v. 99, n. 6, p. 2078-2082, 2008.

KUMAR, N, ANAND, K.G.V e REDDY, M.P. Shoot regeneration from cotyledonary leaf explants of Jatropha curcas: a biodiesel plant. Acta Physiologiae Plantarum, v. 32, p.917924, 2010.

LAVIOLA, B.G.; BHERING, L.L.; MENDONÇA, S.; ROSADO, T.B.; ALBRECHT, J.C. Caracterização morfo-agronômica do banco de germoplasma de pinhão-manso na fase jovem. Bioscience Journal, v. 27, n. 3, p. 371-379, 2011.

LEELA, T., NARESH, B., SRIKANTH REDDY, M., MADHUSUDHAN, N.C.H. e CHERKU, P.D. Morphological, physico-chemical and micropropagation studies in_Jatropha curcas L. and RAPD analysis of the regenerants. Applied Energy, v.88, p. 2071-2079, 2011.

LI, X., AHLMAN, A., LINDGREN, H. e ZHU, L. Highly efficient in vitro regeneration of the industrial oilseed crop Crambe abyssinica. Industrial Crops and Products, v. 33, p. 170-175, 2011.

LIM, S. e TEONG, L. K. Recent trends, opportunities and challenges of biodiesel in Malaysia: an overview. Renewable and Sustainable Energy Reviews, v. 14, n. 3, p. 938-954, 2010.

LIU, X., YE, M., PU, B. e TANG, Z. Risk management for Jatropha curcas based biodiesel industry of Panzhihua Prefecture in Southwest China. Renewable and Sustainable Energy Reviews, v. 16, n. 3, p. 1721-1734, 2012.

LUTZ A. Vegetable oil as fuel-an environmentally and socially compatible concept for Mali. GATE (Eschborn), n. 4, p. 38-46, 1992. 
MAKKAR, H. P. S., ADERIBIGBE, A. O. e BECKER, K. Comparative evaluation of nontoxic and toxic varieties of Jatropha curcas for chemical composition, digestibility, protein degradability and toxic factors. Food chemistry, v. 62, n. 2, p. 207-215, 1998.

MAKKAR, H. P. S., BECKER, K. e SCHMOOK, B. Edible provenances of Jatropha curcas from Quintana Roo state of Mexico and effect of roasting on antinutrient and toxic factors in seeds. Plant Foods for Human Nutrition, v. 52, n. 1, p. 31-36, 1998.

MANGKOEDIHARDJO, S., RATNAWATI, R. e ALFIANTI, N. Phytoremediation of hexavalent chromium polluted soil using Pterocarpus indicus and Jatropha curcas L. World Applied Sciences Journal, v. 4, n. 3, p. 338-342, 2008.

MANGKOEDIHARDJO, S. Jatropha curcas L. for phytoremediation of lead and cadmium polluted soil. World Applied Sciences Journal, v. 4, n. 4, p. 519-522, 2008.

MARTIN, G. e MAYEUX, A., L' Integration dans le Systeme Agraire d'une Plante oleagineuse. Non alimentaire en vue d' accroitre les moyens de producion sans contraintes energetiques. Institut de Recherches pour les Huiles et Oléagineux. 1984. 5 p.

MONTEIRO, L. P. C., DA LUZ, C. C., e MAINIER, F. B. Comparação de oleaginosas para a produção de biodiesel. Engevista, v. 17, p. 232-239, 2015.

MOREIRA, M. A. Programa de melhoramento genético da qualidade de óleo e proteína da soja desenvolvido na UFV. In: Congresso brasileiro de soja. Londrina: Embrapa Soja, 1999. p. 99104.

MUJUMDAR, A. M. e MISAR, A.V. Anti-inflammatory activity of Jatropha curcas roots in mice and rats. Journal of Ethnopharmacology, v. 90, n. 1, p. 11-15, 2004.

MUKHERJEE, P., VARSHNEY, A., JOHNSON, T.S., e JHA, T.B. Jatropha curcas: A Review on Biotechnological Status and Challenges, Plant Biotechnology Reports. 2011.

MURASHIGE, T. e SKOOG, F. A revised medium for rapid growth and biossays with tobacco tissue cultures. Physiologia Plantarum, v. 15, p. 473-497, 1962.

NATH, L. K. e DUTTA, S.K. Wound healing response of the proteolytic enzyme curcain. Resultados da pesquisa. Indian Journal of Pharmacology, v. 24, p. 114-5. 1992.

NERY, A. R., RODRIGUES, L. N., SILVA, M. B. R., FERNANDES, P. D., CHAVES, L. H. G., DANTAS NETO, J. e GHEYI, H. R. Crescimento do pinhão-manso irrigado com águas salinas em ambiente protegido. Revista Brasileira de Engenharia Agrícola e Ambiental, v.13, p.551-558, 2009.

NUNES, C. F., PASQUAL, M., SANTOS, D. D., CUSTÓDIO, T. N., e ARAÚJO, A. D. Diferentes suplementos no cultivo in vitro de embriões de pinhão-manso. Pesquisa agropecuária brasileira, v. 43, n. 1, p. 9-14, 2008.

OGUNWOLE, J.O, CHAUDHARY, D.R, GOSH, A., DAUDU, C.K., CHIKARA, e PATOLIA, S. Contribution of Jatropha curcas to soil quality improvement in a degraded Indian 
entisol. Acta Agriculturae Scandinavica Section B-Soil and Plant Science, v. 58, n. 3, p. 245-251, 2008.

OLIVEIRA, F. D. A., GUEDES, R. A., GOMES, L. P., BEZERRA, F. M., LIMA, L. A., e DE OLIVEIRA, M. K. Interação entre salinidade e bioestimulante no crescimento inicial de pinhãomanso. Revista Brasileira de Engenharia Agrícola e Ambiental, v. 19, p. 204-210. 2015.

OLIVEIRA, S.C., NUNES, A.C.P., CARVALHO, C.R. e CLARINDO, W.R. In vitro polyploidization from shoot tips of Jatropha curcas L.: a biodiesel plant. Plant Growth Regulation, v. 69, p. 79-86, 2013.

OPENSHAW, K. A review of Jatropha curcas: an oil plant of unfulfilled promise. Biomass and Bioenergy, v. 19, n. 1, p. 1-15, 2000.

OSONIYI, O. e ONAJOBI, F. Coagulant and anticoagulant activities in Jatropha curcas latex. Journal of Ethnopharmacology, v. 89, n. 1, p. 101-105, 2003.

PALMER, C.D. e KELLER W.A. Somatic embryogenesis in Crambe abyssinica Hochst. ex R.E. Fries using seedling explants. Plant Cell Tissue Organ Cult, v.104, p.91-100, 2011.

PANDEY, V. C., SINGH, K., SINGH, J. S., KUMAR, A., SINGH, B., e SINGH, R. P. Jatropha curcas: A potential biofuel plant for sustainable environmental development. Renewable and Sustainable Energy Reviews, v.16, 2870-2883. 2012.

PEREIRA, M.D., DIAS, D.C.F.S., BORGES, EE.L., MARTINS FILHO, S., DIAS, L.A.S. e SORIANO, P.E. Physiological quality of physic nut (Jatropha curcas L.) seeds during storage. Journal of Seed Science, v.35, n.1, p.21-27, 2013.

PRADA, J.A., AGUILAR, M.E., ESQUIVEL, A.A. e ENGELMANN, F. Cryopreservation of Seeds and Embryos of Jatropha curcas L. American Journal of Plant Sciences,v. 6, p. 172$180,2015$.

RAJORE, S., SARDANA, J. e BATRA, A. In vitro cloning of J. curcas L. Journal of Plant Biology, v.29, p. 195-198, 2002.

RAJPUROHIT, D., e JHANG, T. In Situ and Ex Situ Conservation of Plant Genetic Resources and Traditional Knowledge. In: Plant Genetic Resources and Traditional Knowledge for Food Security. Springer Singapore, 2015. p. 137-162.

RAZDAN, M.K. Introduction to plant tissue culture, $2^{\text {nd }}$ ed. Enfield: Science Publishers, 2003, p. 287-306.

REED B. M. Plant cryopreservation: a practical guide. Springer, Berlin; 2008.

REUBENS, B., ACHTEN, W. M., MAES, W., DANJON, F., AERTS, R., POESEN, J., e MUYS, B. More than biofuel? Jatropha curcas root system symmetry and potential for soil erosion control. Journal of Arid Environments, v. 75, n. 2, p. 201-205, 2011.

ROBERTS, E.H. Genetic conservation in seed banks. Biological Journal of the Linnean Society. v. 43, p. 23-29. 1991. 
ROBERTS, E.H. Predicting the storage life of seeds. Seed Science and Technology, v. 1, p.449-514, 1973.

ROMIJN, H.A. Land clearing and greenhouse gas emissions from Jatropha biofuels on African Miombo Woodlands. Energy Policy, v. 39, n. 10, p. 5751-5762, 2011.

SAMY, R.P, LGNACIMUTHU, S. e SEN, A. Screening of 34 Indian medicinal plants for antibacterial properties. Journal of Ethnopharmacology, v. 62, n. 2, p. 173-181, 1998.

SARDANA, J., BATRA, A. e ALI, D.J. In vitro plantlet formation and micropropagation of $J$. curcas L. Advan. Plant Science, v.11, p. 167-169. 1998.

SATURNINO, H.M., PACHECO, D.D., KAKIDA, J., TOMINAGA, N. e GONÇALVES, N.P. Cultura do pinhão-manso (Jatropha curcas L.). Informe Agropecuario, Belo Horizonte, v. 26, n. 229, p. 44-74, 2005.

SCHERWINSKI-PEREIRA, J.E e COSTA, F.H.S. Conservação in vitro de recursos genéticos de plantas: estratégias, princípios e aplicações. In: CID, L.P.B. (Ed.). Cultivo in vitro de plantas. Brasília, DF: Embrapa Informação Tecnológica, p. 177-180, 2010.

SCHMOOK, B. e SERRALTA-PERAZA L. J. Curcas: distribution and uses in the Yucatan Peninsula of Mexico. In: Jatropha. Managaua, Nicuagura/Austria: Dbv-Verlag; 1997.

SHARMA, S., SUDHEER, P. D.V.N., VIJAY, A.K.G. e REDDY, M. P. Assessment of genetic stability in micropropagules of Jatropha curcas genotypes by RAPD and AFLP analysis. Industrial Crops e Products, v. 34, p.1003-1009, 2011.

SILITONGA, A. S., ATABANI, A.E., MAHLIA, T.M.I., MASJUKI HH, BADRUDDIN IA, MEKHILEF, S. A review on prospect of Jatropha curcas for biodiesel in Indonesia. Renewable and Sustainable Energy Reviews, v. 15, n. 8, p. 3733-3756, 2011.

SILVA, P.R.F. e FREITAS, T.F.S. Biodiesel: o ônus e o bônus de produzir combustível. Ciência Rural, v. 38, p. 843-851. 2008.

SILVA, R.C., CAMILLO, J., SCHERWINSKI-PEREIRA, J.E. A method for seedling recovery in Jatropha curcas after cryogenic exposure of the seeds. Revista de Biología Tropical. v. 60, p. 473-482, 2012.

SIRIWARDHANA, M., OPATHELLA, G.K.C., JHA, M.K. Initiatives, potential and prospects in Thailand: A review. Energy Policy, v. 37, n. 2, p. 554-559, 2009.

SOARES, B.O. Diversidade genética de genótipos de pinhão-manso por meio de RAPD e ISSR. Dissertação (Mestrado em Produção Vegetal no Simeárido) - Universidade Estadudal de Montes Claros, Montes Claros, MG, 2010. 54p.

SOOMRO, R. e MEMON, R.A. Establishment of callus and suspension culture in Jatropha curcas. Pakistan Journal of Botany, v. 39, p. 2431-2441, 2007. 
SOUSA, A. E. C., GHEYI, H. R., CORREIA, K. G., SOARES, F. A. L. e NOBRE, R.G. Crescimento e consumo hídrico de pinhão-manso sob estresse salino e doses de fósforo. Revista Ciência Agronômica, v.42, p.310-318, 2011.

SUJATHA, M. e MUKTA, N. Morphogenesis and plant regeneration from tissue cultures of Jatropha curcas. Plant Cell, Tissue and Organ Culture, v.44, p: 135-141, 1996.

SUJATHA, M. e REDDY, T.P. Morphogenic responses of Jatropha integerrima explants to cytokinins. Biologia Bratislava, v.55, p. 99-104, 2000.

SUJATHA, M.; MAKKAR, H. P. S.; BECKER, K. Shoot bud proliferation from axillary nodes and leaf sections of non-toxic Jatropha curcas L. Plant Growth Regulation, v. 47, n. 1, p. 8390, 2005.

SURANTHRAN, P., SINNIAH, U. R., SUBRAMANIAM, S., AZIZ, M. A., ROMZI, N., e GANTAIT, S. Effect of plant growth regulators and activated charcoal on in vitro growth and development of oil palm (Elaeis guineensis Jacq. var. Dura) zygotic embryo. African Journal of Biotechnology, v. 10, n. 52, p. 10600-10606, 2013.

THEPSAMRAN N.; THEPSITHAR,C.; THONGPUKDEE, A. In vitro induction of shoots and roots from J. curcas L. explants. The Journal of Horticultural Science and Biotechnology, v. 83, p: 106-112, 2008.

THOMAS, O.O. Re-examination of the antimicrobial activities of Xylopia aethiopica, Carica papaya, Ocimum gratissimum and Jatropha curcas. Fitoterapia, v. 60, p. 147-155, 1989.

THORPE, T.A., HARRY, I.S. e KUMAR, P.P. Application of micropropagation to forestry. In: DEBERGH, P.C. e ZIMMERMAN, R.H. (Eds.). Micropropagation: technology and application. Dordrecht: Kluwer Academic Press. p.311-336, 1991.

TOLMASQUIM, M.T. Perspectivas e planejamento do setor energético no Brasil. Estudos Avançados. v. 26, p.247-260, 2012.

TOMINAGA, N., KAKIDA, J. e EDUARDO K. Y. Cultivo de pinhão - manso para produção de biodiesel. CPT, Serie Agroindústria, 220p. 2007.

TOPPO, D.D., SINGH, G., PURSHOTTAM, D.K. e MISRA, P. Improved in vitro rooting and acclimatization of Jatropha curcas plantlets. Biomass and Bioenergy, v. 44, p.42-46, 2012.

VECCHIA, R. O meio ambiente e as energias renováveis: instrumentos de liderança visionária para a sociedade sustentável. Manole: Barueri. SP, 2010.

WALTERS, C. Orthodoxy, recalcitrance and in-between: describing variation in seed storage characteristics using threshold responses to water loss. Planta, p. 1-10, 2015.

WALTERS, C., BERJAK, P., PAMMENTER, N., KENNEDY, K., e RAVEN, P. Preservation of recalcitrant seeds. Science, v. 339, n. 6122, p. 915-916, 2013.

WEBSTER, G.L. Classification of the Euphorbiaceae. Annals of Missouri Botanical Garden. v. 81, p. 3-32. 1994. 
WEI, Q., LU,W.D., LIAO, Y., PAN, S.L., XU, Y., TANG, L. e CHEN, F. Plant regeneration from epicotyls explants of Jatropha curcas. Journal of Plant Physiology and Molecular Biology, v.30, p: 475-478, 2004.

WILBUR, R. L. A synopsis of Jatropha, subsection Eucurcas, with the description of two new species from Mexico. J. Elisha Mitchell Sci. Soc. p, 92- 101. 1954.

WITHERS, L.A. e ENGELMANN, F. In vitro conservation of plant genetic resources. In: ALTMAN, A. (ed) Agricultural Biotechnology, p. 57-88, 1998.

WITHERS, L.A. e WILLIAMS, J.T. Germplasm conservation in vitro and cryopreservation. In: TORRES, A.C. e CALDAS, L.S. (eds.). Técnicas e aplicações da cultura de tecidos em plantas. Brasília: ABCTP/EMBRAPA-CNP, p.267-286. 1990.

XAVIER, A., OTONI, W.C. e PENCHEL,R.M. Micropropagação e enxertia in vitro de espécies florestais. In: BORÉM, A. (Ed.). Biotecnologia Florestal. Suprema Gráfica e Editora Viçosa, 2007, p. 53-74.

YADAV, S.K., JUWARKAR, A.A., KUMAR, G.P., THAWALE, P.R., SINGH, S.K. e CHAKRABARTI, T. Bioaccumulation and phyto-translocation of arsenic, chromium and zinc by Jatropha curcas L.: impact of dairy sludge and biofertilizer. Bioresource Technology, v. 100, n. 20, p. 4616-4622, 2009.

YE, M., LI, C., FRANCIS, G. e MAKKAR, H.P.S. Current situation and prospects of Jatropha curcas as a multipurpose tree in China. Agroforestry systems, v. 76, n. 2, p. 487-497, 2009.

ZAHAWI, R. A. Establishment and growth of living fence species: an overlooked tool for the restoration of degraded areas in the tropics. Restoration Ecology, v. 13, n. 1, p. 92-102, 2005. 


\section{CAPÍTULO 1}

CARACTERIZAÇÃO MORFOANATÔMICA, HISTOQUÍMICA E BIOQUÍMICA DA GERMINAÇÃ̃O E DO DESENVOLVIMENTO DE PLÂNTULAS DE Jatropha curcas $\mathbf{L}$. 


\section{CARACTERIZAÇÃO MORFOANATÔMICA, HISTOQUÍMICA E BIOQUÍMICA DA GERMINAÇÃO E DO DESENVOLVIMENTO DE PLÂNTULAS DE Jatropha curcas L.}

\section{RESUMO}

O objetivo do trabalho foi caracterizar os aspectos morfoanatômicos, histoquímicos e bioquímicos das sementes durante a germinação e o desenvolvimento de plântulas, assim como identificar as principais substâncias de reservas durante os processos. Para os estudos de germinação, as sementes foram desinfestadas, inoculadas in vitro e mantidas na presença de luz. As avaliações de desenvolvimento e as coletas para as análises morfoanatômicas, histoquímicas e bioquímicas da germinação foram realizadas ao longo do período de cultivo de 30 dias. A caracterização anatômica estrutural foi realizada com o auxílio do corante Azul de Toluidina e para as análises histoquímicas foram utilizados Sudan IV para compostos lipídicos, Xylidine Ponceau para proteínas totais e Reagente de Schiff/ ácido periódico - PAS para polissacarídeos neutros. Para as análises bioquímicas, os materiais oriundos dos diferentes períodos de germinação foram avaliados quanto a percentagem de açucares solúveis totais (AST) e amido, via método colorimétrico, e de proteínas em aparelho CNS, além da quantificação de lipídeos via técnica de derivatização in situ em GC-MS. Anatomicamente, as sementes apresentaram endosperma com células isodiamétricas, paredes delgadas e conteúdo celular visível em formas de gotas de lipídeos e corpos proteicos. Os cotilédones e folhas foram caracterizados por conterem epiderme simples e mesofilo composto por parênquima paliçádico e lacunoso, sendo hipocótilo constituído por cilindro vascular do tipo eustelo. Histoquimicamente, evidenciou-se que os lipídeos e as proteínas aparecem como o principal material de reserva no endosperma. As análises bioquímicas confirmaram a maior presença de ácidos graxos em relação aos demais compostos de reserva no endosperma, principalmente os ácidos oleicos e linoleicos. Na formação da planta, o amido apareceu como a principal composto de reserva, principalmente em hipocótilo e raiz.

Palavras-chave: Jatropha curcas, germinação, mobilização de reservas. anatomia, histoquímica e bioquímica. 
CHARACTERIZATION MORPHOANATOMICAL, HISTOCHEMISTRY AND BIOCHEMISTRY OF GERMINATION AND DEVELOPMENT OF SEEDLINGS OF Jatropha curcas $\mathbf{L}$.

\begin{abstract}
The objective of this study was to characterize the morphological and anatomical, histochemical and biochemical aspects of the seeds during germination and seedling development, and to identify the main substances reserves during the process. For germination studies, the seeds were sterilized, inoculated in vitro and maintained in the presence of light. Development assessments and collections for morphoanatomic analysis, histochemical and biochemical germination were carried out during the 30-day culture period. The anatomical structural characterization was performed with the aid Blue stain and Toluidine for histochemical analyzes were used to Sudan IV lipid compounds, Xylidine ponceau for total protein and Schiff reagent / periodic acid - SAP for neutral polysaccharides. For the biochemical analyzes, the materials from the different periods of germination was evaluated as the percentage of total soluble sugars (AST) and starch via colorimetric method, and protein in the CNS device, and quantification of lipids via derivatization in situ GC-MS. Anatomically, the seeds presented endosperm with isodiametrical cells, thin walls and visible mobile content forms droplets of lipid and protein bodies. The cotyledons and leaves were characterized by having simple epidermis and mesophyll consisting of palisade and spongy parenchyma, and hypocotyl consisting of vascular cylinder of eustele type. Histochemically, it was shown that lipids and proteins appear as the main reserve material in the endosperm. Biochemical analyzes confirmed the increased presence of fatty acids in relation to other reserve compounds in the endosperm, especially oleic and linoleic acids. In the formation of the plant, starch appeared as the primary reserve compound, primarily in hypocotyls and roots.
\end{abstract}

Keywords: Jatropha curcas, germination, mobilization of reserves. anatomy, histochemistry and biochemistry. 


\section{INTRODUÇÃO}

Pertencente à família Euphorbiaceae, o pinhão-manso (Jatropha curcas L.) é uma oleaginosa perene e rústica, com grande potencial para a produção de biodiesel (HELLER, 1996). A espécie é considerada uma alternativa para atender parte da demanda por óleo vegetal promovido pelo Programa Nacional de Produção e Uso de Biodiesel (PNPB) (LAVIOLA et al., 2014).

O pinhão-manso tem destacado potencial para a produção de biodiesel por possuir características agrícolas interessantes, como alta produtividade (3,0 a 4,0 t/ha), alto conteúdo de óleo nas sementes (37 a 40\%), e por não ser utilizado na alimentação humana, configurando como alternativa para a produção de óleo destinado para fins energéticos (ARRUDA et al., 2004). Contudo, apesar da importância das características citadas, a domesticação do pinhãomanso teve início somente nos últimos 30 anos, quando passou a ser pesquisada agronomicamente pela elevada resistência ao stress hídrico, utilização na recuperação de áreas degradadas e aplicação medicinal (SATURNINO et al., 2005; ZAHAWI, 2005; SOUSA et al., 2011; PANDEY et al., 2012; INSANU et al., 2013; NERY et al., 2013; CARVALHO et al., 2015; OLIVEIRA et al., 2015).

Estudos envolvendo análises morfofisiológicas de sementes podem auxiliar no entendimento do processo de germinação, vigor, armazenamento, viabilidade e métodos de propagação da espécie. Além disso, a caracterização de sementes pode fornecer subsídios para diferenciar espécies e caracterizar aspectos ecológicos da planta, como a dispersão, estabelecimento de plântulas e fase da sucessão ecológica (MATHEUS e LOPES, 2007).

Assim, a realização de estudos básicos, internos e externos do material biológico utilizado em pesquisas, bem como a descrição bioquímica da germinação, além de permitir o conhecimento do ciclo germinativo da espécie, também constitui-se num importante instrumento para auxiliar nos programas de melhoramento genético pela melhor discriminação e conhecimento do material biológico (GUSMÃO et al., 2006 e NUNES et al., 2009).

Diversos autores relatam uma relação positiva entre altas taxas de germinação com a massa fresca das sementes de pinhão-manso, além de uma variação no massa, tamanho e largura de sementes oriundas de genótipos diferentes. Isso mostra a necessidade de se caracterizar e avaliar os materiais para que se possa obter um melhor aproveitamento da variabilidade genética, de acordo com a sua finalidade (DAGAR et al., 2004; GINWAL et al., 2004; GINWAL et al, 2005; DIAS et al.,2007; AQUINO et al., 2009; CHRISTRO et al., 2012) 
O conhecimento sobre a germinação de uma planta fornece detalhes em relação à complexa rota de desenvolvimento que inicia o ciclo de vida da planta. E o uso de análises morfoanatômicas do material, utilizando técnicas de microscopia ótica, pode ser fundamental para sua interpretação na identificação e caracterização das estruturas, além de conhecer aspectos da composição química e da fisiologia das sementes das espécies vegetais (PRADO, 2012). A composição química de uma semente também é de interesse prático, porque tanto o vigor, quanto o potencial de armazenamento de sementes são influenciados pelo teor dos compostos de reserva (CARVALHO e NAKAGAWA, 2000).

Devido à importância da espécie e carência de estudos nessa área, o objetivo deste trabalho foi caracterizar morfoanatõmica, histoquímica e bioquímicamentes, as sementes de pinhão-manso (J. curcas L.), durante a germinação e o desenvolvimento de plântulas, bem como identificar as principais substancias de reservas presentes. 


\section{MATERIAL E MÉTODOS}

\subsection{Local dos experimentos e material vegetal utilizado}

Os estudos foram conduzidos nos Laboratórios de Cultura de Tecidos II da Embrapa Recursos Genéticos e Biotecnologia e de Bioquímica de Plantas da Universidade de Brasília, Brasília, DF.

As sementes de pinhão-manso utilizadas nos experimentos foram obtidas de amostras do acesso 115-I-1 do Banco Ativo de Germoplasma de pinhão-manso (BAG-Pinhão-manso), localizado no Campo Experimental da Embrapa Cerrados, em Planaltina - DF.

\subsection{Caracterização biométrica das sementes}

Para os estudos biométricos foram separadas 1000 sementes de pinhão-manso, as quais foram subdivididas em 50 repetições de 20 sementes.

A partir das sementes intactas foram avaliados os parâmetros externos: cor, textura, comprimento, largura e massa das sementes com tegumento. Em seguida, as sementes foram rompidas por pressão mecânica, com o auxílio de alicate cirúrgico para a avaliação dos parâmetros internos: cor, textura, comprimento, largura e massa das sementes sem tegumento (endosperma + embrião). Posteriormente, o endosperma foi rompido para exposição e avaliação do comprimento, largura, massa e cor do embrião.

A massa das amostras foi determinada com o auxílio de balança analítica de precisão (METLER); a mensuração do comprimento e largura foram obtidos a partir de fotos tiradas com máquina fotográfica e as imagens analisadas pelo programa de análise de imagem IMAGE J (SCHNEIDER et al., 2012). As análises de textura e cor foram avaliadas conforme critérios visuais e de tato.

A determinação da umidade das sementes (\%), com e sem tegumento, além do embrião, foi realizada pelo método de estufa a $105 \pm 5^{\circ} \mathrm{C}$, por 24 horas, de acordo com as Regras para Análise de Sementes (BRASIL, 2009), usando-se cinco repetições de 10 sementes cada.

A percentagem de umidade foi calculada na base da massa úmida, aplicando-se a seguinte fórmula:

$\%$ de Umidade $(\mathrm{U})=\frac{100(P-p)}{P-t}$

Onde:

$\mathrm{P}=$ massa inicial, massa do recipiente e sua tampa mais a massa da semente úmida;

$\mathrm{p}=$ massa final, massa do recipiente e sua tampa mais o massa da semente seca;

$\mathrm{t}=$ tara, massa do recipiente com sua tampa. 
A pesagem deve foi em gramas, com três casas decimais.

O resultado final foi obtido através da média aritmética das porcentagens de cada uma das repetições retiradas da amostra de trabalho.

\subsection{Análise morfoanatômica, histoquímica e bioquímica da germinação e do desenvolvimento de plântulas in vitro}

Para maior controle, precisão e caracterização dos resultados, a etapa de germinação das sementes foi realizada sob condições in vitro. Para tanto, utilizaram-se sementes de pinhãomanso sem tegumento, previamente desinfestadas com imersão em álcool etílico (70 \%) por 1 minuto e hipoclorito de sódio (6\% de cloro ativo) por 40 minutos. Posteriormente, em câmara de fluxo laminar, as sementes foram lavadas três vezes em água destilada e autoclavada, e inoculadas em tubos de ensaio ( $25 \times 150 \mathrm{~mm})$, contendo $10 \mathrm{~mL}$ de meio composto apenas por água destilada e ágar à $7 \mathrm{~g} \cdot \mathrm{L}^{-1}$.

Nestas condições de cultivo, o material vegetal foi mantido por 30 dias em sala de crescimento, à temperatura de $25 \pm 2{ }^{\circ} \mathrm{C}$, fotoperíodo de 16 horas e irradiância de $50 \mu \mathrm{mol} . \mathrm{m}^{-}$ ${ }^{2} \cdot s^{-1}$.

O delineamento experimental foi composto de 4 repetições de 10 sementes cada, totalizando 40 unidades experimentais.

\subsubsection{Caracterização morfológica}

Para caracterizar morfologicamente a germinação foram realizadas sete avaliações, a partir das seguintes datas: 0 (na inoculação), 1, 3, 5, 10, 15 e 30 dias. Em cada um destes tempos avaliou-se a formação de raiz, caule e folha, bem como a descrição do aspecto apresentado por cada órgão em desenvolvimento.

\subsubsection{Análise anatômica}

Para as análises anatômicas foram realizadas coletadas de 5 amostras de cada repetição, as quais foram fotografadas e analisadas qualitativamente quanto seu aspecto anatômico.

As datas de coletas foram as mesmas realizadas durante a caracterização morfolófica da germinação (item 2.3.1), sendo coletadas amostras de semente (endosperma e embrião), raiz, hipocótilo, cotilédones, além de folhas. Uma vez coletados, os materiais foram fixados em Karnovsky (KARNOVSKY, 1965), por 48 horas sob vácuo, e estocados em tampão Cacodilato de sódio $(0,05 \mathrm{~N})$ em geladeira. Posteriormente, as amostras foram desidratadas em série etílica 
crescente $(10,20,30 \%$ até álcool etílico) e incluídas em metacrilato (Historesina Technovit 7100, Kulzer, Alemanha).

Após inclusão, os materiais foram seccionados transversalmente em micrótomo rotativo (American Optical), utilizando-se navalhas de aço descartável. Os cortes foram obtidos com espessura de $5 \mu \mathrm{m}$ e a caracterização anatômica estrutural foi realizada com o auxílio do corante metacromático Azul de Toluidina, pH 4,0 (O’BRIEN et al., 1964).

Todas as lâminas foram montadas em Bálsamo-do-Canadá e lamínula, sendo examinadas e fotografadas em fotomicroscópio (AX70TRF, Olympus Optical, Tóquio, Japão) e analisadas qualitativamente quanto a presença e ausência do composto em questão.

\subsubsection{Análise histoquímica}

As amostras utilizadas para as análises histoquímicas foram as mesmas coletadas, fixadas e incluídas para analises anatômicas, conforme descrito no item anterior.

Para as análises histoquímicas os cortes foram corados com Sudan IV (0,3\% em etanol 70\%) para compostos lipídicos (JOHANSEN, 1940); Xylidine Ponceau (0,1\% em ácido acético 3\%) para proteínas totais (O’BRIEN e MCCULLY, 1981) e Reagente de Schiff/ácido periódico - PAS (ácido periódico 0,5\%, reagente de Schiff e água sulfurosa) para polissacarídeos neutros (O’Brien e McCully, 1981).

Todas as lâminas foram montadas em Bálsamo-do-Canadá e lamínula, sendo examinadas e fotografadas em fotomicroscópio (AX70TRF, Olympus Optical, Tóquio, Japão) e analisadas qualitativamente quanto a presença e ausência do composto em questão.

\subsubsection{Análise bioquímica}

Assim como nas demais análises, sementes e plântulas de pinhão-manso foram coletadas durante a avaliação da germinação, nas seguintes datas: 0 (no dia da inoculação), 1, $3,5,10,15$ e 30 dias.

Inicialmente, o material fresco foi pesado, congelado em nitrogênio líquido e posteriormente liofilizado por 72 horas. Após a liofilização, as amostras foram pesadas novamente para obter a massa seca. O experimento foi montado de modo inteiramente casualizado, com 4 repetições para cada tratamento sendo cada repetição formada por 5 sementes.

Quantificação de açúcares solúveis totais (AST) e amido - Os AST das amostras contendo 10 mg de material vegetal foram extraídos em 4 ciclos de extração com etanol 80\%. 
A dosagem foi feita pelo método fenol-sulfúrico e quantificação colorimétrica (DUBOIS et al., 1956). O espectrômetro utilizado foi o Spectro Evolution 201 (Thermo Scientific), com leitura da absorbância em 490 nm, com a curva padrão de glicose. O amido restante da extração de AST foi solubilizado e extraído pelo método enzimático de Amaral et al., (2007). As enzima $\alpha$ amilase e amiloglucosidase (Megazyne) foram utilizadas em 2 ciclos e a dosagem foi feita com adição de GODPOD, utilizando método colorimétrico em equipamento Spectra Max 190 (Molecular Devices) e analisadas com ajuda do programa Soft Max v. 6.1.

Quantificação de Proteínas - A quantificação de proteínas foi realizada em aparelho CNS, utilizando $100 \mathrm{mg}$ de massa seca, sendo a percentagem de proteínas foi estimada a partir da quantificação de nitrogênio transformado em proteína pelo uso do fator de correção 6,25 (KJELDAHL, 1883)

Quantificação de lipídeos - Os lipídeos foram quantificados e classificados utilizando a técnica de derivatização in situ em GC-MS, utilizando $0,5 \mathrm{mg}$ da massa seca adicionado a 0,2 mLde metanol/clorofórmio (1:2 v/v), $0,3 \mathrm{~mL}$ de $\mathrm{HCl}$ à $5 \%$, aquecidos a $85^{\circ} \mathrm{C}$ por 1 hora, seguido pela adição de $1 \mathrm{~mL}$ de hexano e mais 60 minutos de leve agitação. Posteriormente a fase não-polar (superior) foi retirada e analisada (LAURENS et al., 2012). 


\section{RESULTADOS E DISCUSSÃO}

\subsection{Caracterização biométrica das sementes}

Morfologicamente, as sementes de pinhão-manso possuem tegumento preto e áspero. $\mathrm{O}$ endosperma é volumoso e liso, de coloração branca, apresentando ranhuras por toda semente em sentido longitudinal. O embrião, completamente envolto pelo endosperma, apresenta coloração branca, com dois cotilédones folhosos relativamente grandes em relação ao eixo embrionário, com formato cordiforme e nervuras visíveis em ambas às faces foliares. Essas características também foram observadas por Nunes et al. (2009) e Loureiro et al. (2013).

Verificou-se que as sementes com tegumento apresentaram maior massa que sementes sem tegumento, com média de $0,58 \mathrm{~g}, 1,82 \mathrm{~cm}$ de comprimento e $1,11 \mathrm{~cm}$ de largura para as sementes com tegumento e $0,34 \mathrm{~g}, 1,46 \mathrm{~cm}$ de comprimento e $0,85 \mathrm{~cm}$ de largura para sementes sem o tegumento. $\mathrm{O}$ teor de umidade também variou, uma vez que sementes com tegumento apresentaram $17,9 \%$ de umidade e as sem tegumento $16,5 \%$. O embrião é leve e pequeno, com cerca de 0,007g, 1,28 cm de comprimento e 0,67 de largura, com valor de umidade de 31, 9\% (Tabela 1).

Tabela 1: Caracterização biométrica de sementes de pinhão-manso (Jatropha cucas L.)

\begin{tabular}{ccccccc}
\hline & Cor & Textura & Massa $(\mathbf{g})$ & $\begin{array}{c}\text { Comprimento } \\
(\mathbf{c m})\end{array}$ & $\begin{array}{c}\text { Largura } \\
(\mathbf{c m})\end{array}$ & $\begin{array}{c}\text { Umidade } \\
(\%)\end{array}$ \\
\hline $\begin{array}{c}\text { Sementes com } \\
\text { tegumento }\end{array}$ & Preta & Áspero & $0,58 \pm 0,02$ & $1,82 \pm 0,2$ & $1,11 \pm 0,09$ & $17,9 \pm 1,1$ \\
$\begin{array}{c}\text { Sementes sem } \\
\text { tegumento } \\
\text { Embrião }\end{array}$ & Amarelada & Liso & $0,34 \pm 0,01$ & $1,46 \pm 0,3$ & $0,85 \pm 0,01$ & $16,5 \pm 0,9$ \\
\hline
\end{tabular}

Heller (1996) descreve sementes $J$. curcas com cerca de $2 \mathrm{~cm}$ de comprimento por 1 cm de largura, enquanto Christro et al. (2012) descrevem valores semelhantes na avaliação de diferentes genótipos de pinhão-manso. A partir das análises biométricas, podemos inferir que apenas o endosperma possui cerca de $50 \%$ do massa total da semente, seguido pelo tegumento com 40,3\% e, por último, o embrião, que contribui com 7,7\% do massa da semente.

A necessidade da caracterização morfológica e da germinação das espécies vegetais estudadas em pesquisas científicas tem sido apontada por diversos autores como de extrema importância, uma vez que divergências na morfologia da semente, germinação e características de crescimento podem além de indicar formas de variabilidade genética, ajudar na correta caracterização e identificação botânica (GINWAL et al., 2005; GUSMÃO et al., 2006; ALQUINO et al., 2009 e CHRISTRO et al., 2012). 
Sementes são uma estrutura formada pelo óvulo desenvolvido, após a polinização e, em geral, transportam um embrião, uma fonte de energia para a plântula (endosperma) e um tegumento, sendo assim, um propágulo resultante da reprodução sexuada. O tegumento que envolve a semente muitas vezes é o principal responsável pelo controle de permeabilidade de líquidos e gases, e em muitas espécies é o responsável pela dormência física imposta na germinação. Assim, desde que possível, é aconselhável sua remoção para que se possa atingir bons índices de germinação (GONÇALVES e LORENZI, 2012). Em pinhão-manso, Heller (1996) cita que o tegumento pode provocar uma barreira física para a água e a luz, podendo assim ocasionar dormência física das sementes.

\subsection{Análise morfoanatômica, histoquímica e bioquímica da germinação e do desenvolvimentode plântulas de pinhão-manso}

\subsubsection{Caracterização morfológica}

O processo de germinação in vitro das sementes de pinhão-manso se iniciou nas primeiras horas de cultivo, uma vez que as mesmas estavam intumescidas logo ao final do primeiro dia (Figura 1A). A germinação se caracterizou com a protrusão da radícula no terceiro dia (Figura 1B), seguido pelo rompimento total do endosperma e expansão e desenvolvimento das raízes e dos cotilédones que, juntamente com o hipocótilo, apresentaram colocação esverdeada no quinto dia de cultivo (Figura 1C). Após 10 dias, as plântulas já apresentavam raízes desenvolvidas, folhas cotiledonares totalmente expandidas e início do desenvolvimento do primeiro par de folhas verdadeiras (Figura 1D), as quais se encontravam visíveis no $15^{\circ}$ dia de cultivo (Figura 1E) e totalmente expandidas no $30^{\circ}$ dia (Figura 1F). Os padrões de germinação observados nesse trabalho corroboram com os padrões descritos por Nunes et al. (2009) para a espécie. Segundo Loureiro et al. (2013), as sementes de J. curcas são endospermáticas, elípticas e anátropas, com tegumento glabro, possuindo poros e fissuras em sua superfície, sendo a germinação do tipo fanerocotiledonar e epígea. 


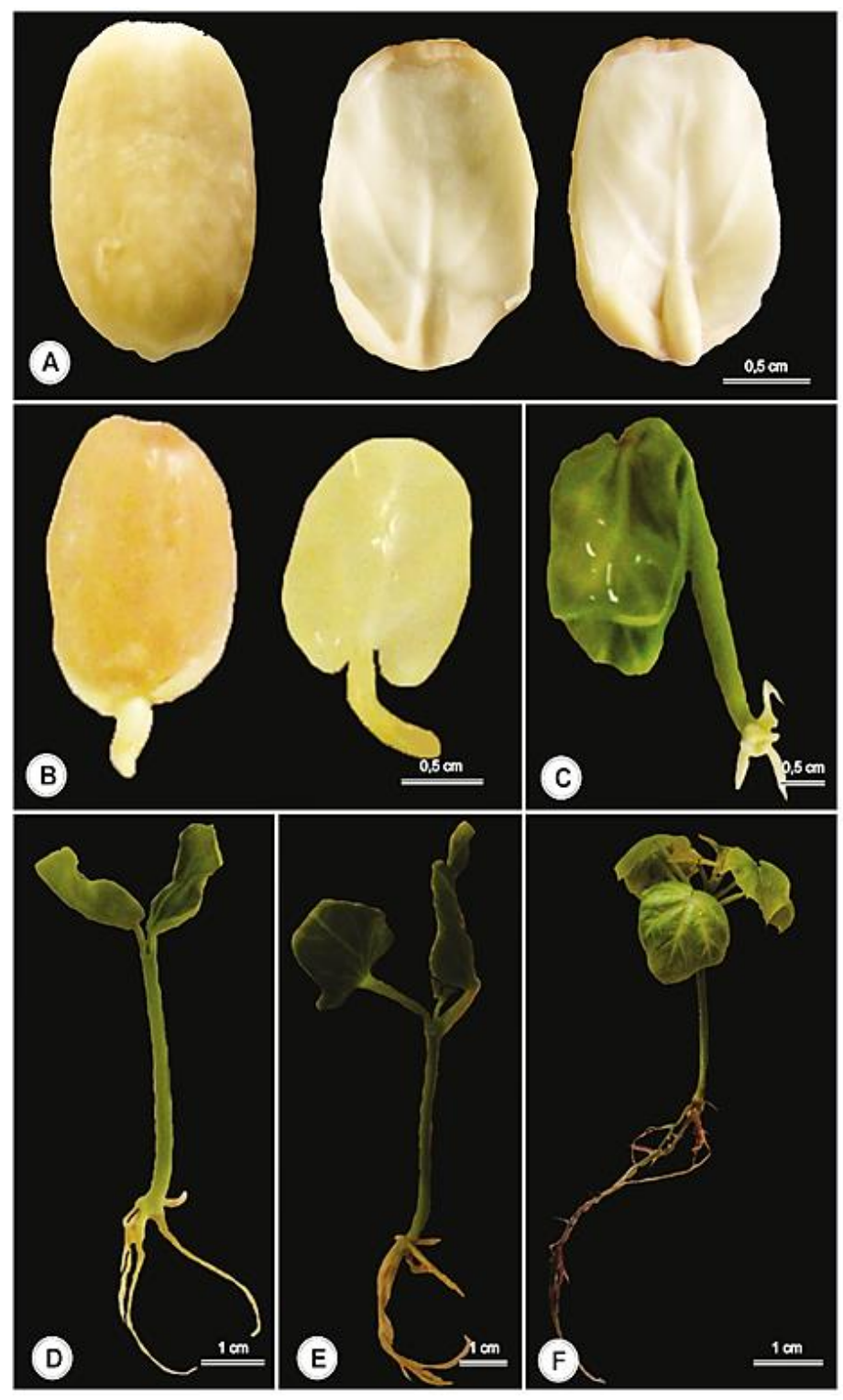

Figura 1: Aspecto morfológico da semente sem tegumento e plântula de pinhão-manso (Jatropha curcas L) durante germinação in vitro. A: semente sem tegumento (esquerda) e semente aberta evidenciando o embrião (direita) no primeiro dia de cultivo. B: semente (esquerda) e embrião (direita) com três dias de cultivo. C: Plântula com 5 dias de cultivo, evidenciando a formação da radícula, hipocótilo e parte aérea. D: Plântula com 10 dias de cultivo, com raízes alongadas, hipocótilo e folhas cotiledonares em expansão. E: Plântula com 15 dias de cultivo com raízes, hipocótilo e cotilédones expandidos e um primórdio foliar. F: Planta com 30 dias de cultivo, apresentando raízes longas e folhas expandidas.

\subsubsection{Análises anatômicas}

Anatomicamente, as sementes de pinhão-manso apresentam endosperma com células arredondadas, com paredes finas e conteúdo celular visualizado em gotas no interior das células (Figura 2A e B). O cotilédone apresenta epiderme composta por células quadradas justapostas (Figura $2 \mathrm{C}$ ), com o mesofilo constituídos de células isodiamétricas arredondadas, sendo ambos os tecidos compostos por células de parede delgada (Figura $2 \mathrm{C}$ e D).

As plântulas de pinhão-manso apresentam folhas cotiledonares com epiderme simples e células arredondadas em ambas as faces. Entretanto, células estreitas e alongadas estão presentes apenas na epiderme abaxial na região da nervura central biconvexa. O mesofilo apresenta parênquima clorofiliano heterogêneo dorsiventral, sendo o parênquima paliçádico 
constituído por apenas uma camada de células, e o parênquima esponjoso amplo, com cerca de seis camada de células delimitando pequenos espaços intercelulares (Figura 2E), sendo o feixe vascular do tipo colateral (Figura 2F)

O eixo embrionário apresenta epiderme com células arredondadas a ovais com parede celular fina, córtex homogêneo com células isodiamétricas, cilindro vascular do tipo eustelo e medula bem definida com células grandes e arredondadas (Figura 2G), sendo o feixe vascular do tipo colateral (Figura 2H). A Figura 2I mostra detalhes do padrão de deposição helicoidal da parede secundária nos elementos traqueais do xilema primário no eixo embrionário.

As folhas completamente expandidas de pinhão-manso, assim como nos cotilédones, apresentam mesofilo heterogêneo com parênquima clorofiliano dorsiventral, sendo uma camada de células no parênquima paliçádico e o parênquima esponjoso amplo, com cerca de seis camada de células delimitando pequenos espaços intercelulares (Figura 2M). A epiderme é simples, sendo em ambas as faces constituídas por células quadradas a eretas, porém maiores na face adaxial (Figura 2M).

Na região da nervura principal, a porção superior é plana ou pouco convexa e a epiderme é simples, com idioblastos e com presença de colênquima angular, em ambas as faces da nervura, feixe vascular do tipo colateral e ausência de fibras (Figura 2J e L).

O caule apresenta cilindro vascular descontinuo, com medula definida, caracterizando cilindro vascular do tipo eustelo (Figura $2 \mathrm{~N}$ ). O padrão de crescimento é primário, com ausência de fibras e colênquima e epiderme simples (Figura $2 \mathrm{~N}$ ), sendo o feixe vascular do tipo colateral (Figura 2O).

Por fim, a raiz apresenta epiderme simples, constituída de células arredondadas e parênquima cortical com células de arredondas de paredes delgadas (Figura 2P). 


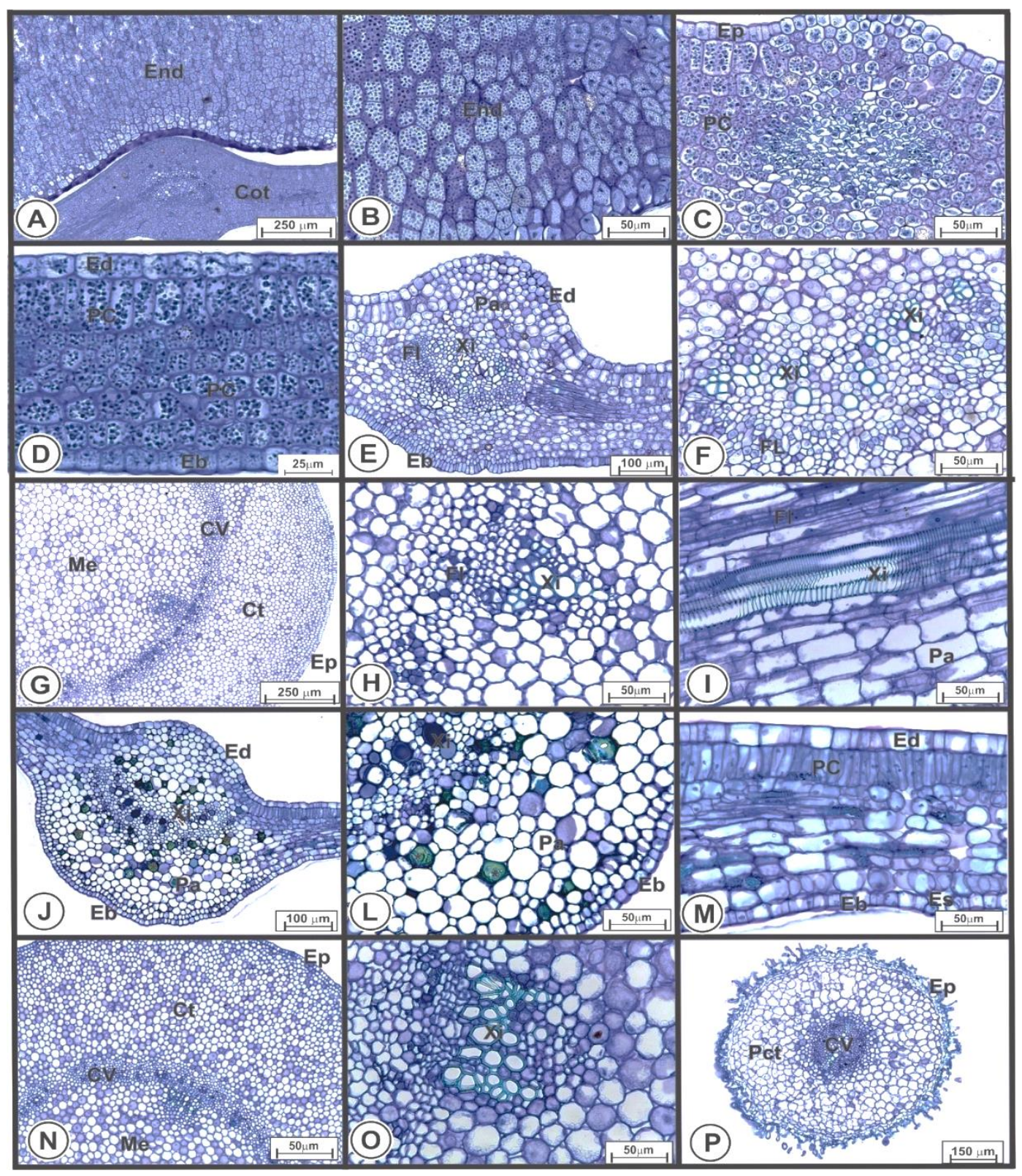

Figura 2: Caracterização anatômica da semente, folhas cotiledonares, folhas, caule e raiz de plântulas de pinhão-manso (Jatropha curcas L.). A-B: Corte transversal da semente evidenciando o embrião com seu par de cotilédones e o endosperma. C-F: Folha cotiledonar apresentando epiderme simples, parênquima clorofiliano heterogêneo e feixe vascular colateral. G-H: Eixo embrionário indicando o córtex, cilindro vascular do tipo eustelo, medula e feixe vascular colateral. I- Corte longitudinal do eixo embrionário indicando a padrão de deposição helicoidal da parede secundária nos elementos traqueais do xilema primário. J-M: Folhas evidenciando nervura central, feixe vascular e mesofilo. N-O. Caule com cilindro vascular do tipo eustelo e medula. P: Raiz com epiderme simples e parênquima cortical. Cot: cotilédone; Emb: embrião; End: endosperma; Ep: epiderme; Ad: epiderme adaxial; Ab: epiderme abaxial; PC: parênquima clorofiliano; FV: feixe vascular; Ct: córtex; Me: medula; PCt: parênquima cortical; Fl: floema e Xi: xilema. *: idioblasto. 


\subsubsection{Análises histoquímicas}

$\mathrm{Na}$ avaliação histoquímica da germinação observou-se o acúmulo de lipídeos apenas no endosperma em todas as fazes da germinação (Tabela 2). Entretanto, verificou-se que a intensidade da coloração com sudan IV foi maior até o terceiro dia de cultivo, sendo identificada gostas de lipídio no endosperma e no embrião (Figura 3A-F). A partir do quinto dia de cultivo a intensidade da coloração apresentou diminuição considerável visualmente, sendo detectado gotas de lipídio apenas nas regiões mais periféricas do endosperma e distantes do embrião (Figura 3 G-M). Com 30 dias de cultivo, a presença de lipídeos no endosperma estava restrita apenas as três últimas camadas de células do endosperma (Figura 3 L-M).

Essa acentuada diminuição na quantidade de lipídeos marcadas pelo sudan IV no decorrer do processe de germinação e desenvolvimento da plântula sugere que os lipídeos são usados como fonte de energia para o crescimento e desenvolvimento da planta, estando inclusive presentes no embrião.

Tabela 2. Análise da presença ou ausência de lipídeos, proteínas e polissacarídeos totais em sementes, endosperma, folha cotiledonar, folha verdadeira, caule e raiz de plântulas de pinhãomanso (Jatropha curcas L.), durante a germinação de sementes in vitro

\begin{tabular}{|c|c|c|c|c|}
\hline $\begin{array}{l}\text { Germinação } \\
\text { (dias) }\end{array}$ & Amostra & $\begin{array}{l}\text { Sudan IV } \\
\text { (Lipídeos) }\end{array}$ & $\begin{array}{c}\text { Xylidine Ponceau } \\
\text { (Proteínas) }\end{array}$ & $\begin{array}{c}\text { PAS } \\
\text { (Polissacarídeos) }\end{array}$ \\
\hline $\mathbf{0}$ & Semente & + & + & - \\
\hline $\mathbf{1}$ & Semente & + & + & - \\
\hline \multirow{3}{*}{3} & Endosperma & + & + & - \\
\hline & Folha cotiledonar & + & + & - \\
\hline & Eixo embrionário & - & + & - \\
\hline \multirow{3}{*}{5} & Endosperma & + & + & - \\
\hline & Folha cotiledonar & + & + & - \\
\hline & Hipocótilo & - & + & + \\
\hline \multirow{4}{*}{10} & Endosperma & + & + & - \\
\hline & Folha cotiledonar & + & + & - \\
\hline & Hipocótilo & - & + & + \\
\hline & Raiz & - & - & - \\
\hline \multirow{5}{*}{15} & Endosperma & + & + & \\
\hline & Folha cotiledonar & - & - & - \\
\hline & Folha & - & - & + \\
\hline & Hipocótilo & - & - & + \\
\hline & Raiz & - & - & + \\
\hline \multirow{5}{*}{30} & Endosperma & + & + & - \\
\hline & Folha cotiledonar & - & - & - \\
\hline & Folha & - & - & - \\
\hline & Hipocótilo & - & - & + \\
\hline & Raiz & - & - & - \\
\hline
\end{tabular}

(+): Positivo para a presença do composto; (-): Negativo para a presença do composto. 


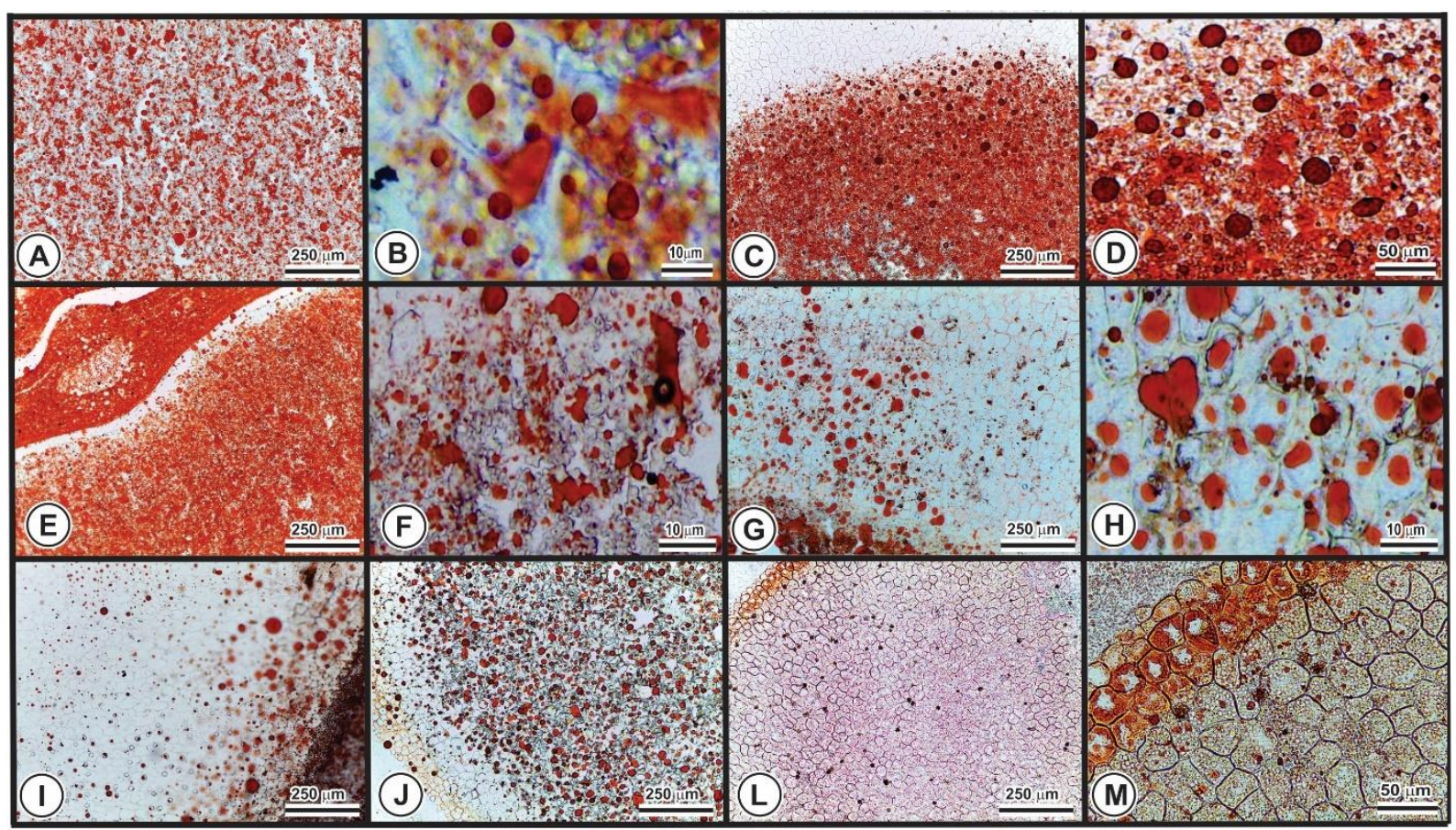

Figura 3: Análise histoquímica de sementes de pinhão-manso cultivadas por até 30 dias e coradas com Sudan IV evidenciando a presença de lipídeos corados de vermelho no interior das células. A-B: endosperma de sementes com zero dias de cultivo; C-D: endosperma de sementes com 1 dia de cultivo; E-F: endosperma e cotilédone de sementes com 3 dias de cultivo; G-H: endosperma de sementes com 5 dias de cultivo; I: endosperma de sementes com 10 dias de cultivo; J: endosperma de sementes com 15 dias de cultivo e L-M: endosperma de sementes com 30 dias de cultivo.

Nas sementes, grande quantidade de corpúsculos proteicos foram visualizados tanto no endosperma quando no embrião, ou seja, tanto nos cotilédones como no eixo embrionário (Figura 4A-C), sendo os mesmos evidenciados com 1 dia (Figura 4D-E) e 3 dias de cultivo (Figura 4F-G).

No $5^{\circ}$ dia de cultivo, além do endosperma (Figura 4L-M), foi possível visualizar proteínas de reserva no cotilédone (Figura $4 \mathrm{H}$ ), em células do parênquima na nervura central (Figura 4I) e em todo o mesofilo e epiderme (Figura $4 \mathrm{~J}$ ).

É interessante observar que proteínas estiveram presentes em células do endosperma e do cotilédone durante todo o processo de germinação. Porém a presença de compostos lipídicos foi verificada apenas no endosperma e em cotilédones, restritamente nas etapas iniciais de germinação, do tempo zero até o décimo dia de cultivo, quando as folhas cotiledonares não se encontravam mais ligadas ao endosperma. 


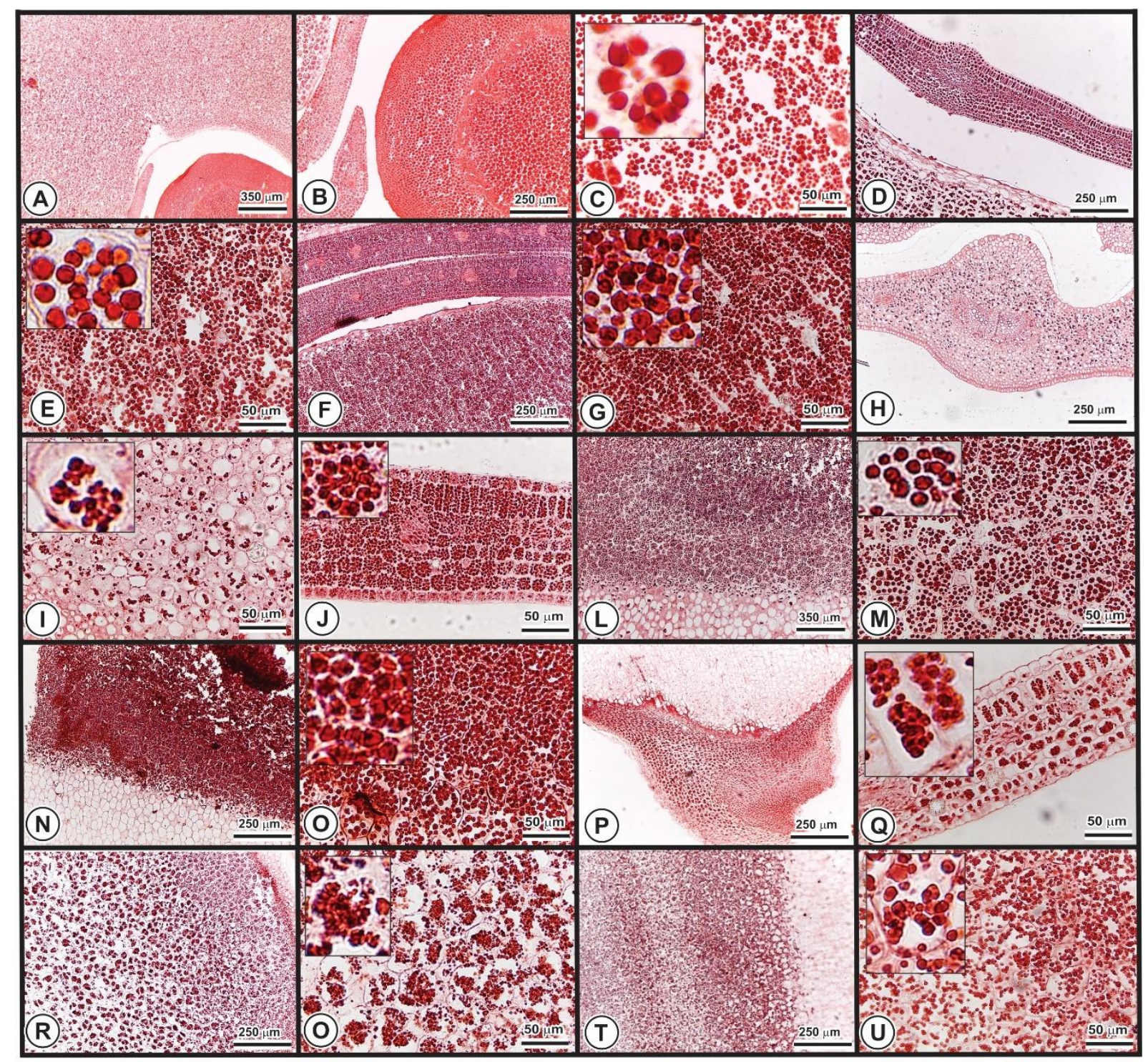

Figura 4: Análise histoquímica de sementes de pinhão-manso cultivadas por até 30 dias e coradas com Xylidine Ponceau evidenciando a presença de proteínas de reserva coradas de vermelho no interior das células. A: semente; B: embrião e $\mathbf{C}$ : endosperma de sementes com zero dias de cultivo. D: cotilédone e E: endosperma de sementes com 1 dia de cultivo. F: semente (cotilédone e endosperma) e G: endosperma de sementes com 3 dias de cultivo; H-J: cotilédone e $\mathbf{M}$ : endosperma de sementes com 5 dias de cultivo; N-O: endosperma; P: eixo e Q: cotilédone de sementes com 10 dias de cultivo; R-O: endosperma de sementes com 15 dias de cultivo e T-U: endosperma de sementes com 30 dias de cultivo.

Os polissarídeos de reserva, como o amido, foram identificados com o auxílio da reação de PAS no hipocótilo das plântulas a partir de $5^{\circ}$ dias de cultivo, sendo que com 15 dias também foi possível visualizar grãos de amido nas folhas e na raiz (Tabela 2).

Na Figura 5 podemos visualizar as regiões onde estão localizados os grãos de amido localizados nas folhas e na raiz. No hipocótilo das plântulas com 5 dias de cultivo uma pequena quantidade de amido pode ser visualizada em célula do córtex ao lado do cilindro vascular (Figura 5 A-B). A deposição de grãos de amido nessa região indica a formação da bainha 
amilífera, a qual pode ser vista mais perfeitamente no hipocótilo de plântulas com 10 dias de cultivo (Figura 5 C-D). Aos 15 dias de cultivo, grãos de amido foram visíveis nas folhas (Figura 5E), principalmente em células do parênquima na nervura central (Figura 5F). No hipocótilo, tanto as células do córtex quanto da medula apresentavam amido (Figura 5G). Na raiz, apenas a região da coifa apresentava uma quantidade significativa desse carboidrato (Figura 5H). Com 30 dias de cultivo a quantidade de amido foi reduzida consideravelmente na plântula, sendo visível somente no hipocótilo, principalmente ao redor do cilindro vascular (Figura 5I-J).

O endosperma é descrito como um tecido nutritivo e triploide da semente, originário da dupla fecundação pela fusão dos núcleos polares e um dos núcleos germinativos, podendo ser mantido até a maturidade da semente ou ser reabsorvido ao longo de sua maturação, sendo um dos principais órgãos de reserva de sementes albuminosas. O cotilédone corresponde a primeira (s) folha (s) de um embrião, ocasionalmente armazenando reserva para a germinação (GONÇALVES e LORENZI, 2012).

De acordo com BUCKERIDGE et al. (2004), os principais compostos de reserva das sementes são a sacarose da série rafinósica, amido, polissacarídeos de parede, lipídeos, proteínas e fitina. Ainda segundo os autores, proteínas, lipídeos e amido são as principais reservas de fonte de carbono, e no caso das proteínas, também fonte de nitrogênio, sendo as duas primeiras utilizadas principalmente na germinação e desenvolvimento da plântula, enquanto o amido na fase de desenvolvimento do vegetal. Isso explica os resultados histoquímicos observados nesse trabalho, uma vez que lipídeos e proteínas foram encontrados em todas as fases de germinação, até a formação do primeiro par de folhar verdadeiras. Já o amido foi identificado apenas no hipocótilo, inclusive após o desligamento da plântula com o endosperma e cotilédones, após a fase germinativa (Tabela 1). 


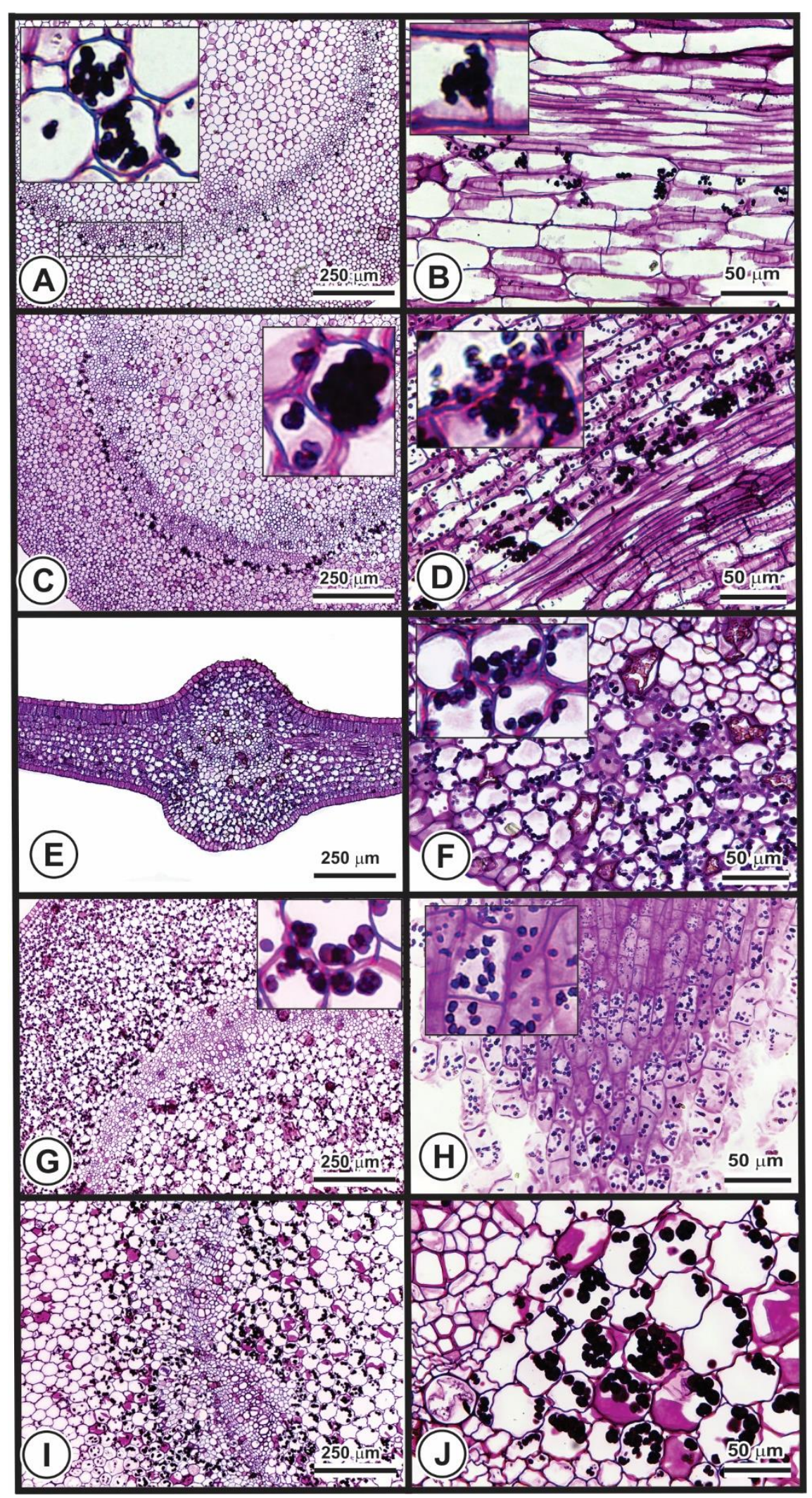

Figura 5: Análise histoquímica de sementes e plântulas de pinhão-manso cultivadas por até 30 dias coradas com PAS evidenciando a presença de amido coradas de magenta no interior das células. A-B: hipocótilo com 5 dias de cultivo corte transversal; A: corte transversal e B: corte longitudinal. C-D: hipocótilo com 10 dias de cultivo evidenciando a bainha amilífera. C: corte transversal e D: corte longitudinal. E-H: corte transversal da plântula com 15 dias de cultivo, E-F: folha, G: hipocótilo e H: Raiz. I-J: corte transversal do hipocótilo com 30 dias de cultivo. 
Em Euphorbia heterophylla (SUDA e GIORGINI, 2000) lipídeos correspondem a cerca de $60 \%$ da massa seca da semente, portanto a principal substância de reserva, ficando as proteínas em segundo lugar correspondendo a $27 \%$ da massa seca da semente.

Segundo Buckeridge et al. (2004), as reservas das sementes têm basicamente duas funções que se relacionam com a manutenção e desenvolvimento do embrião até a formação de uma plântula que apresente a capacidade de se manter de forma autotrófica. Assim, as reservas podem funcionar como fonte de energia para manter processos metabólicos em funcionamento e/ou como fonte de matéria para construção de tecidos vegetais que irão constituir a planta, sendo o endosperma e os cotilédones os principais órgãos de acúmulo de reservas. Segundo Loureiro et al. (2013), em sementes de pinhão-manso a diminuição da quantidade de lipídeos no endosperma durante o processo de embebição da semente se deve a translocação destes para o eixo hipocótilo-radícula, com a finalidade de fornecer energia para o alongamento e crescimento celular durante a germinação das sementes.

A diminuição na presença de lipídeos durante o processo de germinação das sementes de pinhão-manso também foi evidenciada nesse estudo, onde o teste histoquímico indicou a presença de lipídeos nas sementes, principalmente no endosperma até o quinto dia de germinação, quando se iniciou a expansão cotiledonar, a partir da qual proteínas passaram a ser o principal composto de reserva (Tabela 2). Essa observação também foi feita por Suda e Giorgini (2000) em endospermas de Euphorbia heterophylla (Euphorbiaceae). Segundo os autores a degradação dos lipídeos inicia-se após a embebição inicial e é completada entre 72 e 96 horas, enquanto as proteínas são continuamente degradadas após o início da embebição.

\subsubsection{Análise bioquímica}

Entre os principais compostos de reserva em pinhão-manso foi possível verificar que lipídeos e amidos representaram a maior percentagem de massa seca em relação os compostos de reserva analisados no endosperma. Entretanto, conforme o período de germinação e desenvolvimento da plântula, a quantidade de lipídeos no endosperma aumentou expressivamente, principalmente após 5 e 10 dias de cultivo, correspondendo a mais $70 \%$ da massa seca. Com 15 e 30 dias de cultivo, ainda foi considerável a percentagem de lipídeos no endosperma, porém, esta foi inferior a observada nos dois tempos anteriores (Figura 6 A). 


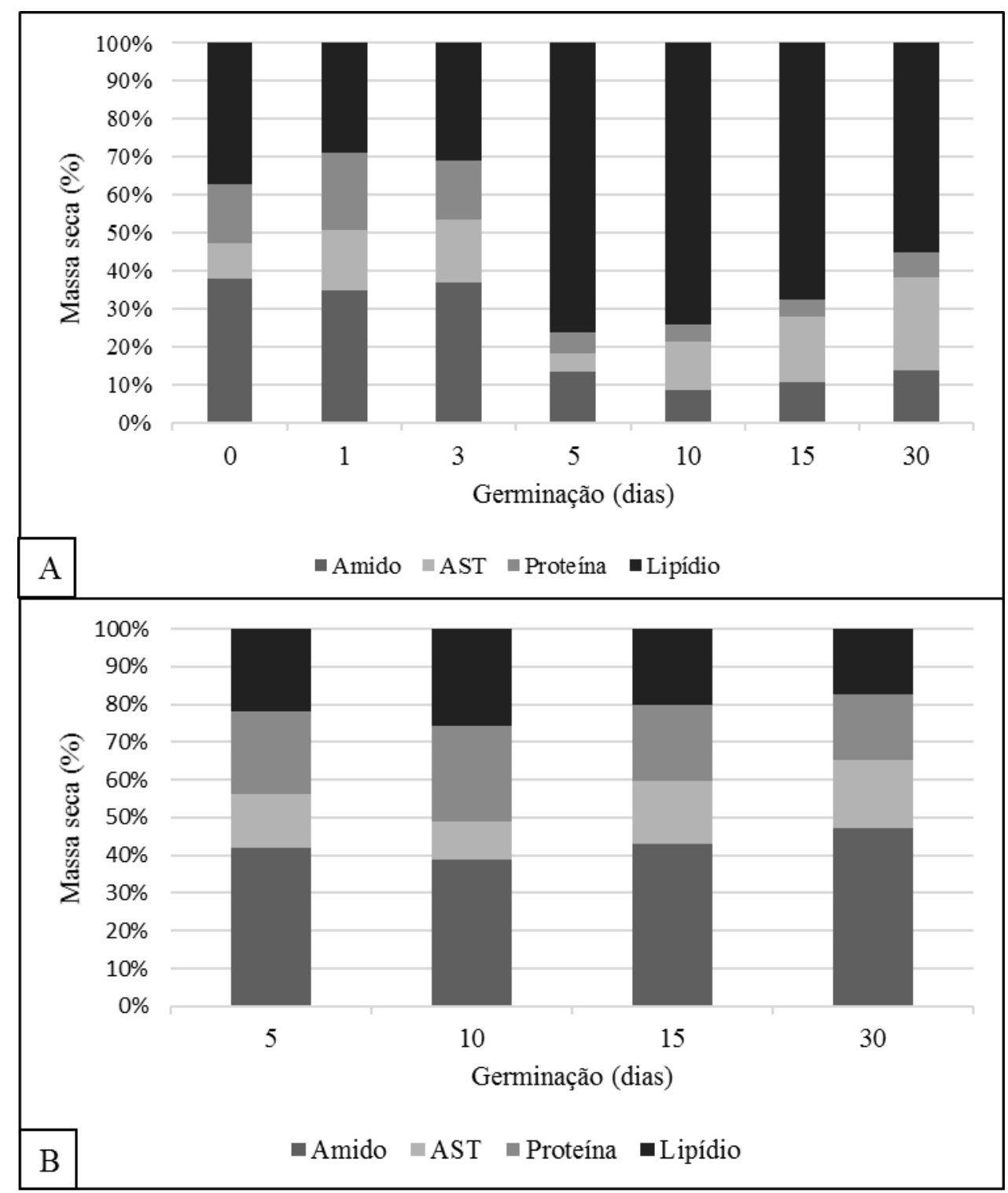

Figura 6: Percentagem de lipídeos, proteínas amido e açúcares solúveis totais (AST) em relação a massa seca de endosperma (A) e plântulas (B) de pinhão-manso (Jatropha curcas L.) durante e pós germinação.

A percentagem de amido, que inicialmente representava mais de $30 \%$ da massa seca do endosperma, aos dez dias de cultivo já era de apenas 10\%. A percentagem de proteínas também caiu a partir de 5 dias de germinação, representando menos $5 \%$ da massa seca do endosperma aos 30 dias de germinação (Figura 6 A).

Em relação a presença de AST, incialmente representando pouco menos de $10 \%$ das reservas analisadas, após 15 dias de cultivo está já representava mais de 15\% das reservas analisadas, chegando a mais de $20 \%$ aos 30 dias de cultivo (Figura 6 A).

A média da concentração de lipídeos nas sementes de pinhão-manso observada neste trabalho foi de cerca de $37 \%$ no tempo zero de germinação, sendo esta média superior as 
observadas por Heller (1996) que relatou teores totais de óleo nas sementes com variação entre 23,7 e $34,1 \%$, com média de $30,2 \%$.

Já em plântulas de pinhão-manso, diferentemente do que foi observado no endosperma, o principal composto de reserva encontrado foi o amido, correspondendo a mais de $40 \%$ de todos os compostos analisados. Lipídeos e proteínas, apareceram em segundo lugar, seguido por AST (Figura 6 B).

De acordo com Graham (2008), durante o processo de germinação, os lipídeos armazenados nas sementes sob a forma de triglicerídeos sofrem hidrólise, liberando glicerol e ácidos graxos livres, os quais são a posteriori utilizados na formação de açúcares que servem como fonte de energia necessária para o desenvolvimento da planta. Essa explicação básica sobre a degradação de lipídeos durante o processo de germinação de sementes oleaginosas explica a variação da percentagem dos compostos de reserva durante a germinação de pinhãomanso.

Inicialmente, até o terceiro dia de cultivo das sementes de pinhão-manso, não houve grandes alterações na percentagem de lipídeos durante o processo de germinação. Porém, a partir do $5^{\circ}$ dia, a quantidade de lipídeos detectada no endosperma aumentou consideravelmente. Corroborando com esses resultados, a análise da massa seca das plântulas formadas durante o processo de germinação, indicou uma percentagem pequena de lipídeos em relação a observada para amido. E segundo Graham (2008), as hexoses geradas a partir da degradação dos triglicerídeos são utilizadas, principalmente, para a síntese de sacarose, a qual será então, transportada para o eixo embrionário em crescimento,

Dentre os tipos de ácidos graxos encontrados em semente e endosperma de pinhãomanso foi possível identificar a presença do ácido palmítico, palmitoleico, esteárico, oleico, linoleico, araquídico, elaidico, behênico e erúcico, porém, esses quatro últimos detectados em baixíssimas concentrações (Tabela 3).

O ácido palmítico foi detectado ainda no tempo zero de germinação na concentração de $0,9 \mu \mathrm{g} \cdot \mathrm{mg}^{-1} \mathrm{MS}$, sendo que no quinto dia de germinação essa concentração mais que dobrou, atingindo cerca de 4,82 $\mu \mathrm{g} . \mathrm{mg}^{-1} \mathrm{MS}$. No $10^{\circ}$ e $15^{\circ}$ dias de germinação, as concentrações foram ainda maiores, atingindo 5,86 e 5,73 $\mu \mathrm{g} . \mathrm{mg}^{-1} \mathrm{MS}$, enquanto que no $30^{\circ}$ dia observou-se uma queda na concentração para 3,54 $\mu \mathrm{g} \cdot \mathrm{mg}^{-1} \mathrm{MS}$ (Tabela 3).

$\mathrm{O}$ ácido palmitoleico apresentou um comportamento semelhante, incialmente com concentrações mais baixas no tempo zero $\left(0,73 \mu \mathrm{g} \cdot \mathrm{mg}^{-1} \mathrm{MS}\right)$, chegando a 2,65 $\mu \mathrm{g} \cdot \mathrm{mg}^{-1} \mathrm{MS}$ aos 
15 dias de germinação, apresentando uma pequena queda para $2,54 \mu \mathrm{g} \cdot \mathrm{mg}^{-1} \mathrm{MS}$ aos 30 dias de cultivo (Tabela 3).

Dentre os ácidos graxos que apresentaram maior concentração estão o ácido oleico e o linoleico, os quais apresentaram uma concentração inicial de 1,82 e 2,22 $\mu \mathrm{g} . \mathrm{mg}^{-1} \mathrm{MS}$, chegando a $10,11 \mu \mathrm{g} \cdot \mathrm{mg}^{-1} \mathrm{MS}$ aos 15 dias de cultivo para o ácido oleico e $14,84 \mu \mathrm{g} \cdot \mathrm{mg}^{-1} \mathrm{MS}$ para o linoleico no décimo dia (Tabela 3).

Tabela 3. Alterações da composição de ácidos graxos (\%) em endosperma de pinhão-manso (Jatropha curcas L) durante o processo de germinação e desenvolvimento de plântulas in vitro.

Massa ( $\mu$ g.mg $\left.{ }^{-1} \mathrm{MS}\right)$

\begin{tabular}{cccccccc}
\hline Ácido graxo & $\mathbf{0}$ & $\mathbf{1 ~ d i a}$ & $\mathbf{3}$ dias & $\mathbf{5}$ dias & $\mathbf{1 0}$ dias & $\mathbf{1 5}$ dias & $\mathbf{3 0}$ dias \\
\hline $\begin{array}{c}\text { Ácido Palmítico } \\
(\text { C16:0) }\end{array}$ & $0,9 \pm 0,5$ & $0,62 \pm 0,5$ & $0,78 \pm 1,1$ & $4,82 \pm 5,6$ & $5,86 \pm 6,6$ & $5,73 \pm 6,0$ & $3,54 \pm 1,77$ \\
$\begin{array}{c}\text { Ácido Palmitoleico } \\
\text { (C16:1) }\end{array}$ & $0,73 \pm 0,3$ & $0,52 \pm 0,3$ & $0,62 \pm 1,0$ & $1,33 \pm 3,0$ & $1,52 \pm 3,5$ & $2,65 \pm 4,6$ & $2,54 \pm 1,27$ \\
$\begin{array}{c}\text { Ácido Esteárico } \\
\text { (C18:0) }\end{array}$ & $0,09 \pm 0,1$ & $0,06 \pm 0,3$ & $0,05 \pm 0,2$ & $1,03 \pm 1,5$ & $1,36 \pm 2,4$ & $1,08 \pm 1,5$ & $0,78 \pm 0,39$ \\
$\begin{array}{c}\text { Ácido Oléico } \\
\text { (C18:1) }\end{array}$ & $1,82 \pm 0,7$ & $0,80 \pm 1,1$ & $0,98 \pm 2,1$ & $9,87 \pm 11,1$ & $9,81 \pm 8,6$ & $10,11 \pm 10,7$ & $6,52 \pm 3,26$ \\
$\begin{array}{c}\text { Ácido Linoléico } \\
\text { (C18:2) }\end{array}$ & $2,22 \pm 0,3$ & $1,41 \pm 0,5$ & $1,71 \pm 2,4$ & $13,69 \pm 15,1$ & $14,84 \pm 14,5$ & $11,51 \pm 9,7$ & $5,77 \pm 2,88$ \\
$\begin{array}{c}\text { Ácido Araquídico } \\
\text { (C20:0) }\end{array}$ & $0,00 \pm 0,0$ & $0,00 \pm 0,0$ & $0,01 \pm 0,1$ & $0,00 \pm 0,0$ & $0,02 \pm 0,0$ & $0,01 \pm 0,0$ & $0,01 \pm 0,00$ \\
$\begin{array}{c}\text { Ácido Elaídico } \\
\text { (C20:1) }\end{array}$ & $0,11 \pm 0,0$ & $0,00 \pm 0,0$ & $0,01 \pm 0,0$ & $0,00 \pm 0,0$ & $0,01 \pm 0,0$ & $0,04 \pm 0,2$ & $0,03 \pm 0,01$ \\
$\begin{array}{c}\text { Ácido Behênico } \\
\text { (C22:0) }\end{array}$ & $0,00 \pm 0,0$ & $0,00 \pm 0,0$ & $0,52 \pm 2,6$ & $0,00 \pm 0,0$ & $0,07 \pm 0,3$ & $0,00 \pm 0,0$ & $0,16 \pm 0,08$ \\
$\begin{array}{c}\text { Ácido Erúcico } \\
\text { (C22:1) }\end{array}$ & $0,06 \pm 0,0$ & $0,01 \pm 0,0$ & $0,04 \pm 1,6$ & $0,08 \pm 0,1$ & $0,16 \pm 0,7$ & $0,03 \pm 0,1$ & $0,10 \pm 0,05$ \\
\hline Total & $5,97 \pm 0,2$ & $3,43 \pm 0,3$ & $4,72 \pm 1,1$ & $30,81 \pm 3,6$ & $33,64 \pm 3,7$ & $31,16 \pm 3,3$ & $19,45 \pm 0,9$ \\
\hline
\end{tabular}

De maneira geral, todos os ácidos graxos detectados durante o processo de germinação de sementes de pinhão-manso no endosperma apresentaram um incremento na sua concentração com o decorrer do tempo de germinação, em especial nos períodos de 5, 10 e 15 dias. Esse incremento está relacionado com a liberação dos ácidos em função da hidrólise dos triglicerídeos, como fonte de carbono e energia para o desenvolvimento da planta (PENFIELD et al., 2008).

A concentração total de lipídeos também aumentou até o $10^{\circ}$ dia de cultivo, apresentando a partir de então uma ligeira queda. Assim, incialmente as sementes continham cerca de 5,75 $\mu$ g.mg ${ }^{-1} \mathrm{MS}$ de lipídeos, passando a 30,81 e 33,63 $\mu \mathrm{g} \cdot \mathrm{mg}^{-1} \mathrm{MS}$ no $5^{\circ}$ e $10^{\circ}$ dia de germinação. Porém, após 15 e 30 dias, a concentração já era de 31,16 e 19,45 $\mu \mathrm{g}^{\mathrm{m}} \mathrm{mg}^{-1} \mathrm{MS}$ (Tabela 3). 
Yang et al. (2009) encontraram resultados semelhantes na avaliação na mobilização de sementes de pinhão-manso embebidas por até 96 horas. Segundo os autores, o ácido oleico e ácido linoleico também foram os que apresentaram maior concentração, seguido de ácido palmítico e o ácido esteárico. Ainda segundo Yang et al. (2009), a concentração desses ácidos graxos também diminui até o $4^{\circ}$ dia de embebição.

Entretanto, sabe-se que, diferentes condições, tais como qualidade do solo, estágio de germinação das sementes, chuva, temperatura e outros fatores ambientais, podem causar variações significativas, tanto no conteúdo de lipídeos, quanto na composição de ácidos graxos em uma mesma espécie vegetal (SENANAYAKE, 2000; RAHAMATALLA et al., 2001). Em plantulas, a concentração dos diferentes lipídeos encontrados foi decrescendo com tempo de germinação e desenvolvimento da planta.

O ácido oleico e o linoleico também aparecem como os principais compostos lipídicos observados em plântulas. Para o primeiro, as concentrações variaram de $8,9 \mu \mathrm{g} \cdot \mathrm{mg}^{-1} \mathrm{MS}$ no $5^{\circ}$ dia de germinação para 6,$78 ; 2,46$ e $0,39 \mu \mathrm{g} \cdot \mathrm{mg}^{-1} \mathrm{MS}$ nos tempos de 10,15 e 30 dias de germinação, respectivamente. Já para o segundo, as concentrações variaram de 14,62; 12,09; 5,98 e 1,61 $\mu \mathrm{g} . \mathrm{mg}^{-1} \mathrm{MS}$ nos tempos de 5, 10, 15 e 30 dias de germinação (Tabela 4).

Tabela 4. Alterações da composição de ácidos graxos (\%) em plântulas de pinhão-manso (Jatropha curcas L) durante o processo de germinação e desenvolvimento de plântulas in vitro.

\begin{tabular}{|c|c|c|c|c|c|c|c|}
\hline \multirow[b]{2}{*}{ Ácido graxo } & \multicolumn{7}{|c|}{ Massa $\left(\mu \mathrm{g} . \mathrm{mg}^{-1} \mathrm{MS}\right)$} \\
\hline & $\mathbf{0}$ & 1 dia & 3 dias & 5 dias & 10 dias & 15 dias & 30 dias \\
\hline $\begin{array}{l}\text { Ácido Palmítico } \\
\text { (C16:0) }\end{array}$ & $0,00 \pm 0,0$ & $0,00 \pm 0,0$ & $0,00 \pm 0,0$ & $4,03 \pm 3,5$ & $3,27 \pm 2,5$ & $1,75 \pm 1,0$ & $0,98 \pm 0,9$ \\
\hline $\begin{array}{c}\text { Ácido Palmitoleico) } \\
\text { C16:1) }\end{array}$ & $0,00 \pm 0,0$ & $0,00 \pm 0,0$ & $0,00 \pm 0,0$ & $2,90 \pm 2,4$ & $2,38 \pm 1,7$ & $1,33 \pm 0,8$ & $0,86 \pm 0,8$ \\
\hline $\begin{array}{l}\text { Ácido Esteárico } \\
\text { (C18:0) }\end{array}$ & $0,00 \pm 0,0$ & $0,00 \pm 0,0$ & $0,00 \pm 0,0$ & $2,61 \pm 2,5$ & $2,36 \pm 2,5$ & $1,17 \pm 0,4$ & $0,33 \pm 0,0$ \\
\hline $\begin{array}{l}\text { Ácido Oléico } \\
\text { (C18:1) }\end{array}$ & $0,00 \pm 0,0$ & $0,00 \pm 0,0$ & $0,00 \pm 0,0$ & $8,69 \pm 7,0$ & $6,78 \pm 5,7$ & $2,46 \pm 1,3$ & $0,39 \pm 0,0$ \\
\hline $\begin{array}{l}\text { Ácido Linoléico } \\
\text { (C18:2) }\end{array}$ & $0,00 \pm 0,0$ & $0,00 \pm 0,0$ & $0,00 \pm 0,0$ & $14,62 \pm 10,4$ & $12,09 \pm 9,6$ & $5,98 \pm 2,1$ & $1,61 \pm 0,1$ \\
\hline $\begin{array}{c}\text { Ácido } \alpha \text {-Linolênico } \\
(\mathrm{C} 18: 3)\end{array}$ & $0,00 \pm 0,0$ & $0,00 \pm 0,0$ & $0,00 \pm 0,0$ & $0,41 \pm 0,4$ & $1,23 \pm 0,7$ & $1,10 \pm 0,6$ & $0,75 \pm 0,6$ \\
\hline $\begin{array}{l}\text { Ácido Araquídico } \\
\text { (C20:0) }\end{array}$ & $0,00 \pm 0,0$ & $0,00 \pm 0,0$ & $0,00 \pm 0,0$ & $0,09 \pm 0,2$ & $0,09 \pm 0,1$ & $0,04 \pm 0,0$ & $0,01 \pm 0,0$ \\
\hline $\begin{array}{l}\text { Ácido Elaídico } \\
\text { (C20:1) }\end{array}$ & $0,00 \pm 0,0$ & $0,00 \pm 0,0$ & $0,00 \pm 0,0$ & $0,05 \pm 0,1$ & $0,01 \pm 0,0$ & $0,02 \pm 0,1$ & $0,08 \pm 0,0$ \\
\hline $\begin{array}{l}\text { Ácido Behênico } \\
\text { (C22:0) }\end{array}$ & $0,00 \pm 0,0$ & $0,00 \pm 0,0$ & $0,00 \pm 0,0$ & $0,48 \pm 2,4$ & $0,00 \pm 0,0$ & $0,00 \pm 0,0$ & $0,01 \pm 0,0$ \\
\hline $\begin{array}{l}\text { Ácido Erúcico } \\
\text { (C22:1) }\end{array}$ & $0,00 \pm 0,0$ & $0,00 \pm 0,0$ & $0,00 \pm 0,0$ & $0,53 \pm 1,2$ & $0,17 \pm 0,4$ & $0,01 \pm 0,0$ & $0,02 \pm 0,0$ \\
\hline Total & $0,00 \pm 0,0$ & $0,00 \pm 0,0$ & $0,00 \pm 0,0$ & $34,40 \pm 3,0$ & $28,37 \pm 2,3$ & $13,87 \pm 0,1$ & $5,04 \pm 0,2$ \\
\hline
\end{tabular}


Nas plantulas foram detectadas a presença do ácido $\alpha$-Linolênico que não foi observado no endosperma. Porém, a concentração desse ácido graxo foi baixa, variando de 0,$42 ; 1,23$; 1,10 e 0,72 $\mu \mathrm{g} \cdot \mathrm{mg}^{-1} \mathrm{MS}$ nos dias 5, 10, 15 e 30 dias de germinação, respectivamente (Tabela 4).

A concentração total de lipídeos também decresceu em plântulas de acordo com o tempo de germinação e desenvolvimento, possivelmente devido ao desenvolvimento da plântula. No $5^{\mathrm{o}}$ dia de cultivo foi verificado $34,40 \mu \mathrm{g} \cdot \mathrm{mg}^{-1} \mathrm{MS}$ de lipídeos, caindo para 28,37 e 13,87 $\mu \mathrm{g} \cdot \mathrm{mg}^{-}$ ${ }^{1} \mathrm{MS}$ no $10^{\circ}$ e $15^{\circ}$ dia, chegando a 5,04 $\mu \mathrm{g} \cdot \mathrm{mg}^{-1} \mathrm{MS}$ no $30^{\circ}$ dia de cultivo (Tabela 4 ). 


\section{CONCLUSÕES}

Com os resultados obtidos neste trabalho, pode-se concluir que:

- As sementes de pinhão-manso apresentam uniformidade quanto as análises biométricas

- Tegumento de coloração preta e textura áspera;

○ $1,82 \mathrm{~cm}$ de comprimento e $1,22 \mathrm{~cm}$ de largura;

○ Massa médio de $0,58 \mathrm{~g}$ e

○ Umidade de $17,86 \%$.

- A germinação é rápida, com 5 dias de cultivo e a formação de plantulas com folhas completamente expandidas aos 30 dias de cultivo;

- Anatomicamente as sementes de pinhão-manso apresentam:

○ Endosperma com células isodiamétricas, com paredes delgadas e conteúdo celular visível em formas de gotas de lipídeos e corpos proteicos e

- Plantas com cotilédones e folhas com epiderme simples e mesofilo composto por parênquima paliçádico e lacunoso e hipocótilo com cilindro vascular do tipo eustelo.

- Histoquimicamente:

- Os lipídeos e proteínas aparecem como o principal material de reserva no endosperma;

- Bioquimicamente:

- Os lipídeos aparecem como o principal material de reserva no endosperma;

- O amido aparece em maiores concentrações nas plântulas;

- Os principais ácidos graxos disponibilizados durante a germinação e pós germinação foram o ácido oleico e o linoleico. 


\section{REFERÊNCIAS BIBLIOGRÁFICAS}

AMARAL, L. D., GASPAR, M., COSTA, P. M. F., AIDAR, M. P. M., BUCKERIDGE, M. S. Novo método enzimático rápido e sensível de extração e dosagem de amido em materiais vegetais. Hoehnea, v. 34, n. 4, p. 425-431, 2007.

AÑEZ, L.M.M., COELHO, M.F.B., ALBUQUERQUE, M.C.F. e DOMBROSKI, J.L.D. Caracterização morfológica dos frutos, das sementes e do desenvolvimento das plântulas de Jatropha elliptica Müll. Arg. (Euphorbiaceae). Revista Brasileira de Botânica, v.28, n 3, p.563-568, 2005.

AQUINO, N.F., AJALA, M.C., DRANSKI, J.A., IGNÁCIO, V.L., MALAVASI, M.M. e MALAVASI, U.C. Morfometria de sementes de Jatropha curcas L. em função da procedência. Revista de Ciências Agroveterinárias. Lages, v.8, n 2, p. 142-145, 2009.

ARRUDA, F.P., BELTRÃO, N.E. De M., ANDRADE, A.P., PEREIRA, W.E. e SEVERINO, L.S. Cultivo de pinhão-manso (Jatropha curcas L.) como alternativa para o Semi-Árido nordestino. Revista Brasileira de Oleaginosas e Fibrosas, v.8, p. 789-799, 2004.

BRASIL. Ministério da agricultura, Pecuaria e Abastecimento. Regras para análises de sementes. Secretaria de Defesa Agropecuária. Brasília, 365 p, 2009.

BRASILEIRO, B., DIAS, D.C.F.S., BHERING, M.C. e DIAS, L.A.S. Floral biology and characterization of seed germination in physic nut (Jatropha curcas L.). Revista Brasileira de Sementes, v. 34, n 4 p. 556 - 562, 2012.

BUCKERIDGE, M. S., SANTOS, H. D., TINÉ, M. A. S., e AIDAR, M. P. M. Mobilização de reservas. FERREIRA, AG; BORGHETTI, F. Germinação: do básico ao aplicado.(Ed.). Porto Alegre: Artmed, 2004.

CARVALHO, C. M. D., MARINHO, A. B., VIANA, T. V. D. A., VALNIR JÚNIOR, M., SILVA, L. L., e GOMES FILHO, R. R. Production components of Jatropha under irrigation and nitrogen fertilization in the semiarid region of Ceará. Revista Brasileira de Engenharia Agrícola e Ambiental, v. 19, p. 871-876. 2015.

CARVALHO, N.M. e NAKAGAWA, J. Sementes: ciência, tecnologia e produção. 4.ed. Jaboticabal: FUNEP, 588p, 2000.

CHRISTRO, L. F., AMARAL, J. F. T. D., LAVIOLA, B. G., MARTINS, L. D., e AMARAL, C. F. Biometric analysis of seeds of genotypes of physic nut (Jatropha curcas L.). Agropecuária Científica no Semiárido, v. 8, n 1, p. 01-03, 2012.

DAGAR, J. C., BHAGWAN H. e KUMAR, Y. Seed germination studies of Salvadora persica and Jatropha curcas. Indian Journal of Forestry, Dehradun, v. 27, n. 3, p. 283-289, 2004.

DIAS, L.A.S., CARVALHO, E., GUIMARÃES, L.M.S., DIAS, D.C.F.S., LAVIOLA, B.G. e LEME, L.P. Analisando a variabilidade genética de pinhão-manso plantado na região de 
Viçosa, MG, Brasil. In: Congresso da rede brasileira de tecnologia de biodiesel, 2., 2007, Brasília. Resumos expandidos, Lavras: UFLA, 2007, p.1-6.

DIAS, L.A.S., LEME, L.P., LAVIOLA, B.G., PALLINI FILHO, A., PEREIRA, O.L., CARVALHO, M., MANFIO, C.E., SANTOS, A.S., SOUSA, L.C.A., OLIVEIRA, T.S. e DIAS, D.C.F.S. Cultivo de pinhão-manso (Jatropha curcas L.) para produção de óleo combustível. Viçosa, MG, 2007. v.1. 40p.

DUBOIS, M., GILlES, K.A., HAMILTON, J.K., REBERS, P.A., SMITH, F. Colorimetric method for determination of sugars and related substances. Analytical chemistry, v. 28, p. 350356, 1956.

GINWAL, H. S., PHARTYAL, S. S., RAWAT, P. S., e SRIVASTAVA, R. L. Seed source variation in morphology, germination and seedling growth of Jatropha curcas Linn. in central India. Silvae Genetica, v. 54, n 2, p. 76-79, 2005.

GINWAL, H. S., RAWAT, P. S. e SRIVASTAVA, R. L. Seed source variation in growth performance and oil yield of Jatropha curcas Linn. in central India. Silvae Genetica, v. 53, n 4, p. 186-191, 2004.

GONÇALVES, E. G. e LORENZI, H. Morfologia Vegetal: Organografia e Dicionário ilustrado de morfologia das plantas vasculares, São Paulo, Instituto Plantarum de Estudos da Flora. 2007.

GRAHAM, I.A. Seed storage oil mobilization. Annual Review of Plant Biology., v. 59, p. 115$142,2008$.

GUSMÃO, E., VIEIRA, F. A. e JÚNIOR, E.M.F. Biometria de frutos e endocarpos de murici (Byrsonima verbascifolia Rich. Ex. A. Juss.). Revista Cerne, Lavras, v. 12, n 1, 2006.

HELLER, J. Physic nut Jatropha Curcas L. Promoting the conservation and use of underutilized and neglected crops; Institute of Plant Genetics and Crop Plant Research (Gartersleben) and International Plant Genetic Resources Institute: Rome, v. 11, 1996.

INSANU, M., DIMAKI, C., WILKINS, R., BROOKER, J., VAN DER LINDE, P., e KAYSER, O. Rational use of Jatropha curcas L. in food and medicine: from toxicity problems to safe applications. Phytochemistry reviews, v. 12, n 1, p. 107-119, 2013.

JOHANSEN, D. A. Plant microtechnique. New York, McGraw-Hill Book Co. Incl., 1940.

KARNOVSKY, M. J. A formaldehyde-glutaraldehyde fixative of high osmolality for use in eletron microscopy. Journal of Cell Biology, New York, v. 27, n 15, p. 137- 138, 1965.

LAURENS, L. M., QUINN, M., VAN WYCHEN, S., TEMPLETON, D. W., WOLFRUM, E. Accurate and reliable quantification of total microalgal fuel potential as fatty acid methyl esters by in situ transesterification. Analytical and bioanalytical chemistry, v. 403, n. 1, p. 167-178, 2012.

LAVIOLA, BG., SILVA, S.D. A., JUHÁSZ, A.C.P, ROCHA, R.B., OLIVEIRA, R.J.P., ALBRECHT, J.C., ALVES, A.A. e ROSADO, T.B. Desempenho agronômico e ganho genético 
pela seleção de pinhão-manso em três regiões do Brasil. Pesquisa Agropecuária Brasileira, v. 49, n 5, p. 356-363, 2014.

LOUREIRO, M.B., TELES, C.A.S., COLARES, C.C.A., ARAÚJO, B.R.N., FERNANDEZ, L.G. e CASTRO, R.D. Caracterização Morfoanatomica e fisiológica de sementes e plântulas de Jatropha curcas L. (Euphorbiaceae). Revista Árvore, Viçosa-MG, v. 37, n 6, p. 1093-1101, 2013.

MATHEUS, M. T. e LOPES, J.C. Morfologia de frutos, sementes e plântulas e germinação de sementes de Erythrina variegata L. Revista Brasileira de Sementes, v. 29, n 3, p. 8-15. 2007.

MURASHIGE, T. e SKOOG, F. A revised medium for rapid growth and biossays with tobacco tissue cultures. Physiologia Plantarum, v. 15, p. 473-497, 1962.

NERY, A. R., RODRIGUES, L. N., SILVA, M. B. R., FERNANDES, P. D., CHAVES, L. H. G., DANTAS NETO, J. e GHEYI, H. R. Crescimento do pinhão-manso irrigado com águas salinas em ambiente protegido. Revista Brasileira de Engenharia Agrícola e Ambiental, v.13, p. 551-558, 2009.

NUNES, C.F., SANTOS, D.N., PASQUAL, M. e VALENTE, T.C.T. Morfologia externa de frutos, sementes e plântulas de pinhão-manso. Pesquisa Agropecuária Brasileira, v. 44, n. 2, P. 207-210, 2008.

O'BRIEN, T. P. e MCCULLY, M. E. The study of plant structure principles and selected methods. Melbourne, Termarcarphi Pty Ltd., 1981.

OLIVEIRA, F. D. A., GUEDES, R. A., GOMES, L. P., BEZERRA, F. M., LIMA, L. A., e DE OLIVEIRA, M. K. Interação entre salinidade e bioestimulante no crescimento inicial de pinhãomanso. Revista Brasileira de Engenharia Agrícola e Ambiental, v. 19, p. 204-210. 2015.

ORBACH, M.A., MALAVASI, U.C., MALAVASI, M.M., AJALA, M.C., LIMA, P.R. e SCHULZ, D.G. Propagation methods for physic nut (Jatropha curcas). Advances in Forestry Science, v.1, n1, p.53-57, 2014.

PANDEY, V. C., SINGH, K., SINGH, J. S., KUMAR, A., SINGH, B., e SINGH, R. P. Jatropha curcas: A potential biofuel plant for sustainable environmental development. Renewable and Sustainable Energy Reviews, v.16, p. 2870-2883. 2012.

PENFIELD, S., GRAHAM, S., GRAHAM, I. A. Storage reserve mobilization in germinating oilseeds: Arabidopsis as a model system. Biochemical Society Transactions, v. 33, n. 2, p. 380-383, 2005.

PRADO, J.P.C. Caracterização morfo-histoquímica da germinação e o desenvolvimento pós-seminal in vitro e formação de culturas nodulares em Vriesea friburgensis Mez var. paludosa (L.B. Smith) L.B. Smith e Vriesea reitzii Leme eamp; A. Costa. Dissertação (mestrado) - Universidade Federal de Santa Catarina, Centro de Ciências Agrárias. Programa de Pós-Graduação em Recursos Genéticos Vegetais, 103 p. 2012. 
RAHAMATALLA, A.B., BABIKER, E.E., KRISHNA, A.G., TINAY, A.H. Changes in fatty acids composition during seed growth and physicochemical characteristics of oil extracted from four safflower cultivars. Plants Food for Human Nutrition, v.56, n.4, p.385-395, 2001.

RAO, G.R., KORWAR, G.R., SHANKER, A.K. e RAMAKRISHNA, Y.S. Genetic associations, variability and diversity in seed characters, growth, reproductive phenology and yield in Jatropha curcas (L.) accessions. Trees: Structure and Function, v.22, p. 697-709, 2008.

SATURNINO, H.M., PACHECO, D.D., KAKIDA, J., TOMINAGA, N. e GONÇALVES, N.P. Cultura do pinhão-manso (Jatropha curcas L.). Informe Agropecuario, Belo Horizonte, v. 26, n. 229, p. 44-74, 2005.

SCHNEIDER, C.A., RASBAND, W.S. e ELICEIRI, K.W. "NIH Image to ImageJ: 25 years of image analysis". Nature Methods, v. 9, p. 671-675, 2012.

SENANAYAKE, N.S.P.J., SHAHIDI, F. Lipid components of borage (Borago officinalis L.) seeds and their changes during germination. The Journal of the American Oil Chemists' Society, v.77, n.1, p.55-61, 2000.

SOUSA, A. E. C., GHEYI, H. R., CORREIA, K. G., SOARES, F. A. L. e NOBRE, R.G. Crescimento e consumo hídrico de pinhão-manso sob estresse salino e doses de fósforo. Revista Ciência Agronômica, v. 42, p. 310-318, 2011.

SUDA, C. N. K. e GIORGINI, J. F. Composição e mobilização de reserva da semente de Euphorbia heterophylla durante a germinação e desenvolvimento inicial da plântula. Revista Brasileira de Fisiologia Vegetal, v. 12, n. 3, p. 226-245, 2000.

YANG, M. F., LIU, Y. J., LIU, Y., CHEN, H., CHEN, F., SHEN, S. H. Proteomic analysis of oil mobilization in seed germination and postgermination development of Jatropha curcas. Journal of proteome research, v. 8, n. 3, p. 1441-1451, 2009.

ZAHAWI, R. A. Establishment and growth of living fence species: an overlooked tool for the restoration of degraded areas in the tropics. Restoration Ecology, v. 13, n. 1, p. 92-102, 2005. 


\section{CAPÍTULO 2}

COMPORTAMENTO INTERMEDIÁRIO PARA SEMENTES DE PINHÃO-MANSO: UMA NOVA CLASSIFICAÇÃO QUE PODE INFLUENCIAR OS MÉTODOS DE CONSERVAÇÃO EX SITU DA ESPÉCIE 


\section{COMPORTAMENTO INTERMEDIÁRIO PARA SEMENTES DE PINHÃO-MANSO: UMA NOVA CLASSIFICAÇÃO QUE PODE INFLUENCIAR OS MÉTODOS DE CONSERVAÇÃO EX SITU DA ESPÉCIE}

\section{RESUMO}

O objetivo do trabalho foi avaliar o comportamento de sementes e eixos embrionários de pinhão-manso durante diferentes condições de armazenamento e propor estratégias para a correta conservação ex situ da espécie. Primeiramente, realizou-se o processo de dessecação das sementes em sílica-gel por 0, 24, 48, 96 e 192 horas. Para cada tempo de dessecação, as sementes foram armazenadas por $0,180,360$ e 720 dias em diferentes condições de temperatura $\left(25^{\circ} \mathrm{C}, 6^{\circ} \mathrm{C},-20^{\circ} \mathrm{C} \mathrm{e}-196^{\circ} \mathrm{C}\right)$. Transcorrido o tempo de conservação, as sementes foram avaliadas pelo teste de condutividade elétrica e germinadas in vitro, sendo a taxa de germinação avaliada após 30 dias de cultivo. Para a criopreservação de eixos embrionários foi realizado a extração dos eixos embrionários em condições assépticas, seguida pela hidratação nos mesmos por 1 hora em placa de petri contendo papel filtro umedecido com água destilada estéril. Em seguida, aplicou-se os tempos de dessecação por exposição ao fluxo de ar da câmara de fluxo laminar por 0, 2, 4, 6, 8 e 10 horas. Após a dessecação, os eixos foram criopreservados por 0, 2, 30, 90, 180 e 360 dias. Transcorrido o tempo de criopreservação foi realizado o teste de germinação in vitro, com avaliação após 30 dias de cultivo. Para ambos os experimentos, a umidade inicial do material vegetal foi avaliada, bem como após cada tempo de dessecação. As sementes de pinhão-manso se mostraram tolerantes a dessecação, mantendo a viabilidade com até $4,3 \%$ de umidade. Porém, não toleraram o armazenamento por até 720 dias em baixas temperaturas, sugerindo um comportamento intermediário de armazenamento. O teste de condutividade elétrica na avaliação da qualidade das sementes apresentou alta correlação com a taxa de germinação. A criopreservação de eixos embrionários com umidades de 9,4 e 7,6\% foi eficaz, apresentando mais de $90 \%$ de germinação, sendo assim considerado a melhor técnica de conservação a longo prazo desta espécie.

Palavras-chave: Jatropha curcas, conservação ex situ, sementes, eixos embrionários, tolerância a dessecação. 


\title{
BEHAVIOR FOR INTERMEDIATE PINHÃO-MANSO SEEDS: A NEW CLASSIFICATION THAT MAY INFLUENCE THE CONSERVATION METHODS OF EX SITU SPECIES
}

\begin{abstract}
The objective was to evaluate the seed behavior and embryonic axis of pinhão-manso during different storage conditions and propose strategies for proper ex situ conservation of the species. First, there was the drying process of the seeds on silica gel with 0, 24, 48, 96 and 192 hours. For each drying time, the seeds were stored for $0,180,360$ and 720 days in different temperature conditions $\left(25^{\circ} \mathrm{C}, 6^{\circ} \mathrm{C},-20^{\circ} \mathrm{C}\right.$ and $\left.-196^{\circ} \mathrm{C}\right)$. Elapsed time of conservation, the seeds were evaluated by electrical conductivity test and in vitro germinated, and the germination rate evaluated after 30 days of cultivation. For cryopreservation embryonic axis was performed at embryonic axes extraction under aseptic conditions, followed by hydration in them for 1 hour in petri dishes containing filter paper moistened with sterile distilled water. Then, the applied time of drying by exposure to air flow from laminar flow hood for $0,2,4,6,8$ and 10 hours. After desiccation, the axes were cryopreserved by 0, 2, 30, 90, 180 and 360 days. Elapsed time of cryopreservation was performed in vitro germination test, with evaluation after 30 days of cultivation. For both experiments, the initial moisture of the plant material was evaluated, and after each time desiccation. The pinhão-manso seeds showed desiccation tolerant, maintaining the viability of up to $4.3 \%$ moisture. But not tolerate storage for up to 720 days at low temperatures, suggesting a storage intermediate behavior. The electrical conductivity test to evaluate the quality of the seeds was highly correlated with the germination rate. Cryopreservation of embryonic axis with moisture content of 9.4 and $7.6 \%$ was effective, with over $90 \%$ germination, and therefore considered the best long-term conservation technique of this kind.
\end{abstract}

Keywords: Jatropha curcas, ex situ conservation, seeds, embryonic axes, tolerance to desiccation. 


\section{INTRODUÇÃO}

O pinhão-manso (Jatropha curcas L.), pertencente à família Euphorbiaceae, é uma espécie adaptada as condições edafoclimáticas brasileiras, principalmente às do Nordeste, onde seu crescimento e desenvolvimento são tidos como ótimo (ARRUDA et al., 2004). A quantidade de óleo encontrada em suas sementes está entre $37 \%$ e $40 \%$ ) e sua produtividade varia muito em função da região de plantio, método de cultivo e tratos culturais, idade da cultura, bem como da quantidade de chuva e da fertilidade do solo e, notadamente, genótipo utilizado (MUKHERJEE et al., 2011; PANDEY et al., 2012). Segundo Brasil (1985), em espaçamento 3x3, o rendimento anual de óleo pode atingir de 3,0 a 4,0 t/ha. Já para Carnielli (2003), o pinhão-manso produz, no mínimo, 2,0 t/ha/ano.

Entretanto, apesar da importância da espécie, cientificamente ainda são relativamente poucos os estudos que relatam técnicas de propagação, cultivo e conservação de germoplasma (OPENSHAW, 2000; SATURNINO, et al., 2005; BELTRÃO, 2006; NUNES et al., 2009; CARELS, 2009; GOLDFARB et al, 2011; HÖRING et al., 2011; MUKHERJEE et al., 2011; SILVA et al., 2011; ZONTA et al., 2011; PANDEY et al., 2012; PINTO JÚNIOR et al., 2012 e PRADA et al., 2015).

Quando se trata de conservação ex situ a semente é o propágulo preferido para a conservação de germoplasma, devido ao relativo baixo custo de armazenamento, facilidade de manuseio e regeneração de plantas inteiras (CHIN, 1994; PRITCHARD, 2008). Assim, a conservação de sementes tem sido a forma mais rotineiramente utilizada para garantir a disponibilidade de recursos genéticos vegetais em longo prazo (ROBERTS, 1989).

Todavia, o sucesso do armazenamento de sementes depende do conhecimento sobre o comportamento destas durante este processo, o que possibilita a utilização de condições adequadas para a manutenção da viabilidade (HONG e ELLIS, 1996).

As sementes são classificadas em três grupos distintos com relação ao comportamento no armazenamento. No primeiro estão as ortodoxas, que se mantém viáveis após dessecação até um grau de umidade em torno de $5 \%$ e podem ser armazenadas sob baixas temperaturas por um longo período. No segundo grupo têm-se as recalcitrantes, ou sementes sensíveis à dessecação, que não sobrevivem com baixos níveis de umidade, o que impede o seu armazenamento por longo prazo (ROBERTS, 1973). Além destes grupos há um terceiro, no qual as sementes apresentam um comportamento de armazenamento intermediário ao ortodoxo e ao recalcitrante (Ellis et al., 1990). E, de acordo com Hong e Ellis (1996), as sementes que apresentam comportamento intermediário são aquelas que toleram a desidratação até valores 
próximos a $7,0 \%$ a $10 \%$ de umidade e não toleram baixas temperaturas durante período de tempo prolongado. Assim, a classificação das sementes quanto à capacidade de armazenamento depende de estudos de tolerância à dessecação e do armazenamento sob temperaturas baixas (HONG e ELLIS, 1996).

As sementes de pinhão-manso são caracterizadas como ortodoxas (DENG et al., 2008; SILVA et al., 2012), embora outros autores relatam perdas de até 50\% de viabilidade, após armazenamento de 15 meses (JOKER e JEPSEN, 2003; PRADA, et al., 2015). E, assim como em pinhão-manso, outras espécies também classificadas como ortodoxas foram avaliadas quanto ao armazenamento a longo prazo, verificando-se em algumas delas, como em Arachis hypogaea (GAGLIARDI et al., 2003), Cuphea carthagenensis (CRANE et al., 2006) e Prunus avium L (CHMILARZ, 2009) que a viabilidade de sementes também ricas em óleo, podem ser reduzidas com o tempo de armazenamento, sendo nesses casos mais adequadamente classificadas como intermediárias.

Segundo Crane et al. (2006), espécies com sementes intermediárias podem ser características daquelas com grande quantidade de lipídios, que perdem a viabilidade quando armazenadas por longos períodos de tempo, devido ao estresse provocado pela desidratação e exposição a baixa temperatura. Ainda segundo os autores, neste tipo de semente a temperatura baixa, geralmente abaixo de zero, cristaliza a água e os lipídios, provocando, assim, injúrias nas células da semente quando esta é colocada para germinar, após a conservação. Neste caso, estratégias convencionais não são efetivas para a conservação das sementes.

Entre as técnicas de conservação ex situ, a utilização da criogenia é uma das alternativas mais promissoras para o armazenamento a longo prazo, pois nessa temperatura, as divisões celulares e processos metabólicos são drasticamente reduzidos e o material vegetal pode, assim, ser armazenado sem alterações ou modificações por um período de tempo teoricamente ilimitado. Além disso, as sementes podem ser armazenadas em um volume pequeno e protegidas da contaminação ou ataque de microrganismos (SANTOS, 2000; ALMEIDA et al., 2010; GOLDFARB et al., 2010; ENGELMANN, 2011; PRADA et al., 2015).

Mas apesar de todas as vantagens já descritas do uso de técnicas criogênicas para a conservação de sementes a longo prazo, a eficiência da criopreservação também depende de uma série de fatores, entre os quais, a velocidade de congelamento e descongelamento dos propágulos (CROWE, 1990). Ainda em 1982, Styles e colaboradores avaliaram a criopreservação de sementes de 24 espécies submetidas ao teste de descongelamento rápido e lento, após o tempo de criopreservação. Segundo os autores, os melhores resultados foram com 
descongelamento rápido em banho maria a $40^{\circ} \mathrm{C}$ por 90 segundos. Entretanto, Marin et al. (1990) chama a atenção para o fato de que o descongelamento rápido poder provocar danos físicos devido a diferenças nas propriedades de expansão entre as partes das sementes, levando a formação de fissuras que podem alterar o contato com cotilédones e endosperma. Tendo em vista que as informações sobre a fisiologia e conservação de sementes de pinhão-manso ainda são limitadas e controversas, este trabalho teve por objetivo avaliar o comportamento de sementes de pinhão-manso (Jatropha curcas L.) durante condições de armazenamento, além de propor métodos e estratégias para a correta conservação ex situ da espécie. 


\section{MATERIAL E MÉTODOS}

\subsection{Local dos experimentos e material vegetal utilizado}

Os estudos foram conduzidos no Laboratório de Cultura de Tecidos II e anexos da Embrapa Recursos Genéticos e Biotecnologia, Brasília, DF.

As sementes de pinhão-manso utilizadas nos experimentos foram obtidas de amostras do acesso 115-I-1 do Banco Ativo de Germoplasma de pinhão-manso (BAG-Pinhão-manso), localizado no Campo Experimental da Embrapa Cerrados, em Planaltina - DF.

\subsection{Conservação a longo prazo de sementes de pinhão-manso}

\subsubsection{Determinação do grau de umidade inicial das sementes}

Para a determinação da umidade inicial das sementes utilizou-se a metodologia de estufa a $105 \pm 5^{\circ} \mathrm{C}$ por 24 horas, de acordo com as Regras para Análise de Sementes (BRASIL, 2009). A umidade foi calculada na base do peso úmido, aplicando-se a seguinte fórmula:

$\%$ de Umidade $(\mathrm{U})=\frac{100(P-p)}{P-t}$

Onde:

$\mathrm{P}=$ peso inicial; peso do recipiente e sua tampa mais o peso da semente úmida;

$\mathrm{p}$ = peso final; peso do recipiente e sua tampa mais o peso da semente seca;

$\mathrm{t}=$ tara; peso do recipiente com sua tampa.

O resultado final foi obtido em percentagem, por meio da média aritmética das percentagens de cada uma das repetições retiradas da amostra de trabalho. Para a determinação da umidade utilizaram-se cinco repetições de 5 sementes cada.

\subsubsection{Dessecação das sementes}

Depois de verificada a umidade inicial, as sementes foram colocadas para dessecar em bandejas de plástico com tampa ( 30 × 30 × $10 \mathrm{~cm}$ ), contendo em cada bandeja $2 \mathrm{~kg}$ de sílica gel azul, a qual foi coberta com papel filtro, de modo que as sementes ficaram espalhadas uniformemente sobre o papel, sem contato direto com a sílica.

As bandejas contendo a sílica gel e as sementes foram então tampadas e lacradas com fita adesiva e acomodadas em sala com temperatura de $25^{\circ} \mathrm{C}$.

Os tempos de dessecação das sementes em sílica gel foram de: 0, 24, 48, 96 e 192 horas. Após transcorrido cada tempo, amostras de cinco sementes de cada bandeja foram pesadas para verificação da umidade, aplicando-se a fórmula citada anteriormente (item 2.2.1). 


\subsubsection{Armazenamento das sementes}

Após cada tempo de dessecação, as sementes foram acondicionadas em envelopes aluminizados trifoliolados (polietileno-alumínio-polietileno), lacrados com seladora e identificados. Em seguida, os materiais foram colocados em quatro condições de temperatura: $6{ }^{\circ} \mathrm{C}, 25^{\circ} \mathrm{C},-20^{\circ} \mathrm{C} \mathrm{e}-196^{\circ} \mathrm{C}$ (nitrogênio líquido). Na temperatura de $-196^{\circ} \mathrm{C}$ os envelopes foram colocados em canisters de alumínio e armazenados em botijões contendo nitrogênio líquido. $\mathrm{Na}$ temperatura de -20 e $6{ }^{\circ} \mathrm{C}$, os envelopes foram acomodados em caixa de papelão devidamente identificada e armazenados em câmara fria, conforme procedimentos usados pelo Banco de Sementes da Embrapa Recursos Genéticos e Biotecnologia. Já os envelopes contendo as sementes para o armazenamento a $25^{\circ} \mathrm{C}$ foram acomodados em caixa de papelão e acondicionados em sala de crescimento.

Nestas condições de temperatura de armazenamento, as sementes ficaram armazenadas por até 720 dias, com avaliações aos 0 (controle), 180, 360 e 720 dias.

\subsubsection{Análise da germinação e teste de condutividade elétrica de sementes de pinhão- manso conservadas}

Transcorridos os tempos de conservação, os envelopes contendo as sementes foram retirados dos locais de armazenamento e as sementes preparadas para o teste de germinação.

\subsubsection{Teste de descongelamento de sementes de pinhão-manso armazenadas em temperaturas sub-zero por 180 dias}

Inicialmente, as sementes armazenadas por 180 dias nas temperaturas de $-20^{\circ} \mathrm{C} \mathrm{e}-196$ ${ }^{\circ} \mathrm{C}$ foram avaliadas quanto a melhor maneira de descongelamento. Nesse teste, os envelopes contendo as sementes congeladas foram submetidas a dois métodos de descongelamento: Rápido (em banho-maria à $40^{\circ} \mathrm{C}$ por 3 minutos) e Lento (temperatura ambiente por 24 horas).

A etapa de germinação das sementes foi realizada sob condições in vitro, conforme protocolo descrito por Silva et al. (2012), com algumas modificações. Para tanto, realizou-se a remoção do tegumento das sementes com o auxílio de alicate cirúrgico. Posteriormente, as sementes de pinhão-manso sem tegumento foram desinfestadas pela imersão em álcool etílico (70 \%) por 1 minuto e hipoclorito de sódio (6\% de cloro ativo) por 40 minutos. Em câmara de fluxo laminar, as sementes foram então lavadas três vezes em água destilada e autoclavada para remoção do hipoclorito de sódio, e inoculadas em tubos de ensaio ( 25 x $150 \mathrm{~mm})$, contendo 10 $\mathrm{mL}$ de sais e vitaminadas do meio de cultura de MS (MURASHIGE e SKOOG, 1962), acrescido de 30 g.L . $^{-1}$ de sacarose e 2,5 g.L L $^{-1}$ de Phytagel. 
Nestas condições de cultivo, o material vegetal foi mantido por 30 dias, em sala de crescimento, à temperatura de $25 \pm 2{ }^{\circ} \mathrm{C}$, fotoperíodo de 16 horas e irradiância de $52 \mu \mathrm{mol} . \mathrm{m}^{-}$ ${ }^{2} \cdot \mathrm{s}^{-1}$.

Transcorrido os 30 dias de cultivo realizou-se a avaliação da germinação das sementes. Nessa avaliação foi considerada como germinadas sementes que apresentaram a protrusão e curvatura da radícula, bem como características de uma plântula normal, como coloração esverdeada dos eixos embrionários, desenvolvimento e expansão do hipocótilo, cotilédones e raízes.

\subsubsection{Análise da germinação e teste de condutividade elétrica de sementes de pinhão- manso}

Após ser determinado a melhor forma de descongelamento das sementes de pinhãomanso e transcorrido o tempo de armazenamento, as sementes foram postas para germinar conforme descrito anteriormente (2.2.4.1).

Para o teste de condutividade elétrica, uma parte das sementes oriundas dos testes de conservação tiveram seus tegumentos removidos, conforme procedimento descrito anteriormente, sendo imersas em $40 \mathrm{~mL}$ de água ultrapura $\left(\mathrm{MiliQ}^{\circledR}\right)$. As sementes foram incubadas em ambiente climatizado a $25^{\circ} \mathrm{C}$ por 24 horas onde, posteriormente, realizou-se a retirada das sementes e a análise da água por leitura em condutivímetro digital (Hanna $\left.{ }^{\circledR}\right)$.

\subsubsection{Delineamento experimental}

O delineamento experimental utilizado neste experimento foi o inteiramente casualizado, em fatorial triplo 5 x 4 x 4, sendo 5 umidades $(15,4 \%, 9,7 \%, 6,5 \%, 5,1 \%$ e 4,3 $\%), 4$ temperaturas de armazenamento $\left(25,6,-20\right.$ e $\left.-196^{\circ} \mathrm{C}\right)$ e 4 tempos de conservação $(0,180$, 360 e 720 dias), totalizando 80 tratamentos. Cada tratamento foi composto por 5 repetições de 25 sementes para cada repetição. Após cada tempo de conservação foram avaliados: teor de umidade, taxa de germinação das sementes, além da condutividade elétrica de cada tratamento.

Para avaliação da germinabilidade e da condutividade elétrica foram utilizadas 10 sementes por repetição para cada variável analisada, enquanto que para a verificação da umidade utilizaram-se 5 sementes por repetição. Assim, do total das sementes utilizadas de cada tratamento, 50 sementes foram utilizadas para avaliação da germinabilidade, 50 sementes para o teste de condutividade elétrica e 25 sementes para avaliação do teor de umidade. 
Para o teste de descongelamento, o delineamento experimental utilizado foi em fatorial duplo 5x2, sendo 5 tempos de dessecação $(0,24,48$, 96 e 192 horas) e 2 métodos de descongelamento (rápido e o lento), totalizando 10 tratamentos. Cada tratamento foi formado por 5 repetições cada, sendo cada repetição composta por 10 sementes.

\subsection{Criopreservação de eixos embrionários de pinhão-manso}

Inicialmente, com o auxílio de alicate cirúrgico foi realizada a remoção do tegumento das sementes, seguida pela desinfestação das sementes em álcool (70\%) por 1 minuto e imersão em hipoclorito de sódio ( $6 \%$ de cloro ativo) por 30 minutos. Posteriormente foram realizadas três lavagens em água destilada e autoclavada em câmara de fluxo laminar.

Após o processo de desinfestação, com o auxílio de pinças e bisturis realizou-se a retirada do eixo embrionário das sementes de pinhão-manso. Para se evitar danos no eixo embrionário, realizou-se a retirada do mesmo com cerva de $2 \mathrm{~mm}$ de cotilédone, o qual também foi importante para dar suporte para a pinça durante a remoção do eixo embrionário. Todo o processo de remoção dos eixos embrionários foi realizado em câmara de fluxo laminar.

Após a remoção dos eixos embrionários, os mesmos foram dispostos em placas de petri descartáveis (15 x $90 \mathrm{~mm}$ ), contendo duas folhas de papel filtro umedecido com água destilada e autoclavada para embebição e padronização da umidade. O tempo de embebição foi de 60 minutos.

Transcorrido o tempo de embebição, os eixos embrionários foram transferidos para placas de petri, contendo duas folhas de papel filtro seco para posterior processo de dessecação em câmara de fluxo laminar.

\subsubsection{Determinação da umidade inicial dos eixos embrionários}

Para a determinação da umidade inicial dos eixos embrionários utilizou-se a mesma metodologia descrita no item 2.2.1 para determinação da umidade inicial das sementes. Porém, para eixos embrionários utilizaram-se dez repetições com 10 eixos embrionários cada. Os eixos embrionários utilizados nesta etapa foram oriundos dos materiais hidratados, conforme metodologia citada anteriormente. 


\subsubsection{Dessecação dos eixos embrionários}

Depois de obtida a umidade inicial, os eixos embrionários foram colocados para dessecar em dez placas de petri descartáveis $(15$ x $90 \mathrm{~mm})$, contendo duas folhas de papel filtro secas, de modo que os eixos embrionários ficaram espalhados de maneira uniforme sobre o papel. As placas de petri foram então abertas e dispostas uniformemente dentro da câmara de fluxo laminar para dessecação dos eixos embrionários.

O tempo de exposição dos eixos embrionários ao fluxo de ar da câmara foi de: 0, 2, 4, 6, 8 e 10 horas. Após transcorrido cada tempo de dessecação, amostras de dez eixos embrionários de cada placa de petri foram pesadas para verificação da umidade, aplicando-se a fórmula citada na etapa de determinação da umidade inicial dos eixos embrionários.

\subsubsection{Armazenamento dos eixos embrionários}

Após cada tempo de dessecação em câmara de fluxo laminar, os eixos embrionários foram acondicionados em criotubos de $1,5 \mathrm{~mL}$ e identificados. Os tempos de criopreservação foram de: 0 (controle - sem nitrogênio líquido), 2, 30, 90, 180 e 360 dias em nitrogênio líquido.

\subsubsection{Análise da germinação de eixos embrionários criopreservados}

Transcorridos os tempos de criopreservação, os criotubos contendo os eixos embrionários foram retirados do nitrogênio líquido e preparados para germinação. Para tanto, uma vez retirados do nitrogênio líquido, os criotubos contendo os eixos embrionários foram mergulhados em banho maria a $40^{\circ} \mathrm{C}$ por 90 segundos para descongelamento dos eixos embrionários.

Uma vez realizado o processo de descongelamento, os eixos embrionários foram colocados para germinar. A etapa de germinação foi realizada sob condições in vitro. Para tanto, em câmara de fluxo laminar, os eixos embrionários foram inoculados em tubos de ensaio $(25 \mathrm{x}$ $150 \mathrm{~mm}$ ), contendo $10 \mathrm{~mL}$ do meio de cultura de MS (MURASHIGE e SKOOG, 1962), acrescido de 30 g.L $\mathrm{L}^{-1}$ de sacarose e 2,5 g. $\mathrm{L}^{-1}$ de Phytagel.

Nestas condições de cultivo, o material vegetal foi mantido por 30 dias em sala de crescimento, à temperatura de $25 \pm 2{ }^{\circ} \mathrm{C}$, fotoperíodo de 16 horas e irradiância de $52 \mu$ mol.m $2 \cdot \mathrm{s}^{-1}$.

Transcorrido os 30 dias de cultivo, se realizou a avaliação da germinação. Nessa avaliação foram considerados como germinados os eixos embrionários que apresentaram crescimento e curvatura da radícula, bem como características de uma plântula normal, como 
coloração esverdeada, desenvolvimento e expansão do eixo, além de crescimento e desenvolvimento do hipocótilo e das raízes.

\subsubsection{Delineamento experimental}

$\mathrm{O}$ delineamento experimental utilizado neste experimento foi $\mathrm{o}$ inteiramente casualizado, em fatorial $6 \times 6$, sendo 6 períodos de dessecação $(0,2,4,6,8$ e 10 horas) e 6 tempos de armazenamento (0,2, 30, 90, 180 e 360 dias), totalizando 36 tratamentos. Cada tratamento foi composto por 5 repetições de 30 eixos embrionários para cada repetição, totalizando 150 eixos embrionários por tratamento. Transcorrido cada tempo de criopreservação foram avaliados o teor de umidade e a taxa de germinação de cada tratamento.

\subsection{Análise estatística}

Todos os dados obtidos foram submetidos à análise de variância (ANOVA), empregando-se o programa ASSISTAT Versão 7.7 beta (2011) (SILVA e AZEVEDO, 2009), sendo a médias dos tratamentos comparadas pelo teste de Scott-Knott a 5\% de probabilidade. 


\section{RESULTADOS E DISCUSSÃO}

\subsection{Conservação de sementes de pinhão-manso}

\subsubsection{Determinação do grau de umidade das sementes}

Na Figura 1 pode ser observado a curva de dessecação das sementes de pinhão-manso em razão do tempo de dessecação. Verificou-se que as sementes apresentaram umidade inicial de $15,4 \%$, a qual foi nitidamente decrescendo com o aumento tempo de exposição ao tratamento com sílica gel, alcançando 4,3\% de umidade, após 192 horas de dessecação.

A dessecação das sementes de pinhão-manso não influenciou significativamente a germinação das sementes que foi acima de 80\% (Tabela 1).

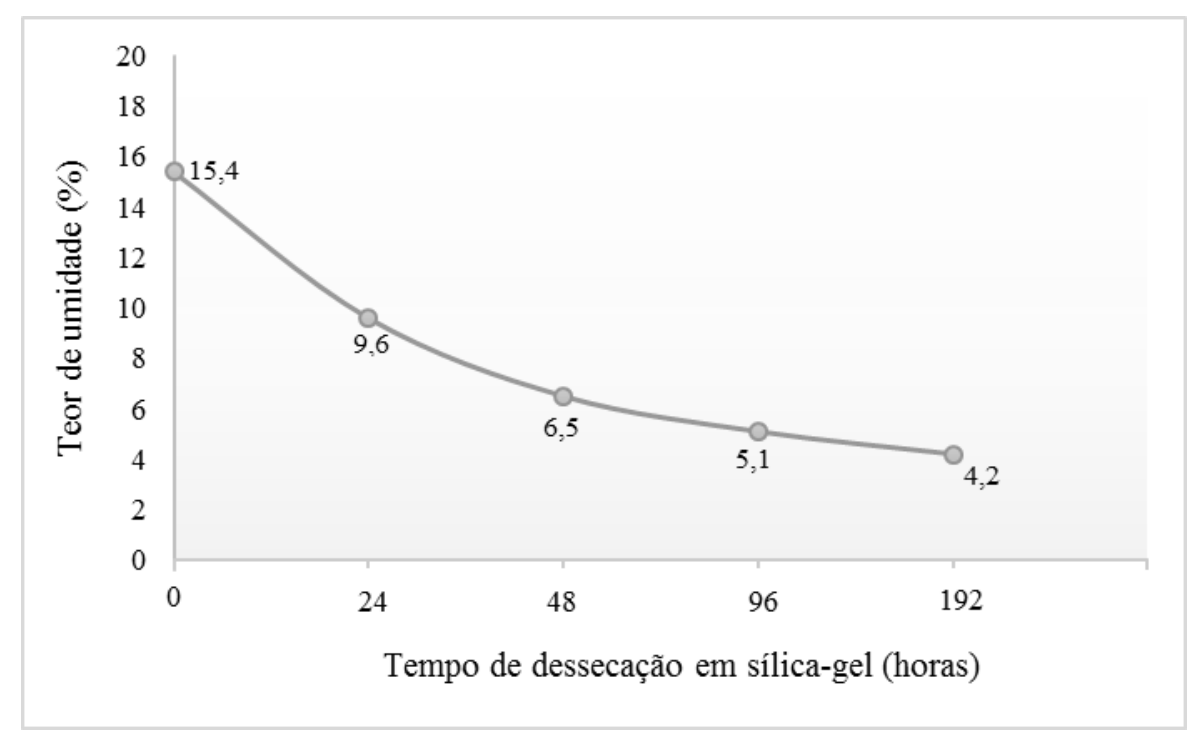

Figura 1. Curva de dessecação de sementes de pinhão-manso (Jatropha curcas L.) em sílica gel em razão do tempo de dessecação.

Tabela 1. Germinação de sementes de pinhão-manso (Jatropha curcas L) em função do teor de umidade em sementes ${ }^{\mathrm{z}}$.

\begin{tabular}{cc}
\hline Teor de umidade $(\%)$ & Germinação $(\%)$ \\
\hline $\mathbf{1 5 , 4}$ & $82,3 \pm 2,11 \mathrm{a}$ \\
$\mathbf{9 , 6}$ & $86,2 \pm 4,3 \mathrm{a}$ \\
$\mathbf{6 , 5}$ & $80,5 \pm 3,3 \mathrm{a}$ \\
$\mathbf{5 , 1}$ & $82,1 \pm 2,5 \mathrm{a}$ \\
$\mathbf{4 , 2}$ & $82,2 \pm 2,1 \mathrm{a}$ \\
\hline
\end{tabular}

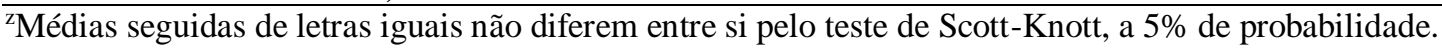

Resultados semelhantes foram descritos por Silva et al. (2012) que também avaliaram a dessecação de sementes de pinhão-manso em sílica gel por até 120 horas e observaram que com o tempo de exposição a sílica gel a umidade decresceu para 6,4\% nas primeiras 24 horas de secagem, até atingir 2,4\% de umidade com 120 horas de dessecação. E, segundo os autores, mesmo nesta umidade, não houve influência da umidade sobre a percentagem de germinação. 


\subsubsection{Teste de descongelamento de sementes de pinhão-manso armazenadas em temperaturas sub-zero por 180 dias}

Nesse trabalho, sementes armazenadas nas temperaturas de $-20^{\circ} \mathrm{C}$ e em nitrogênio líquido, após 6 meses de conservação, passaram por um teste para se verificar qual o melhor método de descongelamento das sementes, o qual seria então utilizado para os demais tempos de conservação.

Na Tabela 2 pode ser observado a taxa de germinação das sementes em relação as temperaturas de armazenamento, teor de umidade e o tipo de descongelamento. Verificou-se que sementes conservadas a $-20^{\circ} \mathrm{C}$ não apresentaram diferenças estatísticas entre os tipos de descongelamento. Já para os tratamentos onde as sementes foram armazenadas em nitrogênio líquido, apenas os tratamentos com sementes apresentando umidade de 9,7 e 6,5\% apresentaram diferenças estatísticas entre os dois tipos de descongelamento.

Tabela 2: Germinação de sementes de pinhão-manso (Jatropha curcas L.) em relação a temperatura de armazenamento, teor de umidade e tipo de descongelamento das sementes armazenadas por 180 dias

\begin{tabular}{|c|c|c|c|c|c|c|}
\hline \multirow{2}{*}{$\begin{array}{l}\text { Temperatura de } \\
\text { armazenamento }\end{array}$} & \multirow{2}{*}{$\begin{array}{c}\text { Tipo de } \\
\text { descongelamento }\end{array}$} & \multicolumn{5}{|c|}{ Teor de umidade das sementes (\%) } \\
\hline & & 15,4 & 9,7 & 6,5 & 5,1 & 4,3 \\
\hline \multirow{2}{*}{$-20^{\circ} \mathrm{C}$} & Rápido & $52,0 \pm 6,0 \mathrm{aB}$ & $78,0 \pm 2,0 \mathrm{aA}$ & $70,0 \pm 4,0 \mathrm{aB}$ & $86,0 \pm 4,0 \mathrm{aA}$ & $80,0 \pm 3,0 \mathrm{aA}$ \\
\hline & Lento & $40,0 \pm 6,0 \mathrm{aC}$ & $88,0 \pm 4,0 \mathrm{aA}$ & $80,0 \pm 3,0 \mathrm{aA}$ & $76,0 \pm 4,0 \mathrm{aB}$ & $70,0 \pm 3,0 \mathrm{aB}$ \\
\hline \multirow{2}{*}{$-196^{\circ} \mathrm{C}$} & Rápido & $40,0 \pm 3,0 \mathrm{aC}$ & $56,0 \pm 2,0 \mathrm{cB}$ & $74,0 \pm 2,0 \mathrm{aA}$ & $86,0 \pm 4,0 \mathrm{aA}$ & $82,0 \pm 4,0 \mathrm{aA}$ \\
\hline & Lento & $42,0 \pm 5,0 \mathrm{aB}$ & $68,0 \pm 4,0 \mathrm{bA}$ & $38,0 \pm 7,0 \mathrm{bB}$ & $78,0 \pm 5,0 \mathrm{aA}$ & $74,0 \pm 4,0 \mathrm{aA}$ \\
\hline
\end{tabular}

${ }^{\bar{Z}}$ Médias seguidas pela mesma letra, minúscula nas colunas e maiúsculas nas linhas não diferem pelo teste de ScottKnott ao nível de $5 \%$ de probabilidade.

Segundo Fonseca et al. (2012), ao se armazenar semententes em baixas temperaturas, principalmente em condições de nitrogênio líquido, é importante se levar em conta o método de descongelamento delas, pois quanto mais rápido ocorrer o descongelamento das sementes, melhor a preservação de suas caracteristivas fisiológicas. Em diferentes cultivares de girassol conservadas em temperaturas subzero por até 6 meses, o método de descongelamento afetou a germinação das sementes (MOTTA et al., 2014). Segundo os autores, sementes descongeladas rapidamente em banho maria apresentaram maior germinação, após o periodo de conservação.

De acordo com Benson et al. (2000), tanto a velocidade de congelamento quanto a de descongelamento influenciam a germinação e, quanto mais rápido ocorrer o descongelamento das sementes, melhor deve ser a preservação de suas características fisiológicas. Para os autores, o método de descongelamento lento (temperatura ambiente) se torna questionável, uma vez que existe a possibilidade de ocorrer um recongelamento durante este período, ocosionando a 
formação de cristais de gelo que podem provocar injurias na membrana plasmática, resultando em danos ou morte celular.

Nesse trabalho, apesar de não ter sido observado diferenças significativas nos tratamentos com as umidades mais baixas (entre 5,1 e 4,3\%), foi possível verificar que as sementes apresentaram taxas levemente mais elevadas de germinação, quando descongeladas rapidamente (acima de 80\%). Assim sendo, optou-se pelo teste de descongelamento rápido para os demais tempos de conservação.

\subsubsection{Análise da germinação e teste de condutividade elétrica de sementes de pinhão- manso}

\subsubsection{Análise da germinação}

$\mathrm{Na}$ Tabela 3 pode-se verificar a taxa de germinação em função dos períodos, das temperaturas de armazenamento e das umidades das sementes. Durante o tempo zero (controle) de conservação não foram observadas diferenças estatísticas significativas de germinação entre as umidades das sementes, sugerindo que mesmo com diferenças de umidade variando entre 15,4 e 4,3\%, as sementes mostraram-se viáveis, com até $86 \%$ de germinação

No entanto, a combinação das diferentes umidades com o tempo de armazenamento e as diferentes temperaturas de conservação refletiram significativamente na germinação das sementes, notadamente com queda da germinação, em todas as temperaturas de conservação analisadas (Tabela 3).

Inicialmente, todas as sementes apresentaram mais de $80 \%$ de germinação, independente da umidade em que elas se encontravam. Porém, após 720 dias de conservação os tratamentos com umidade inicial $(15,4 \%)$ apresentam queda de $100 \%$ na germinação em todas as temperaturas de armazenamento. Já nos tratamentos com 9,7\% de umidade a maior taxa de germinação observada após 720 dias, foi de $68 \%$ na conservação a $6^{\circ} \mathrm{C}$. O mesmo foi observado para os tratamentos com 6,5; 5,1 e 4,3\% de umidade, os quais apresentaram 74, 72 e $60 \%$ de germinação após esta condição de armazenamento.

Quando armazenadas em temperaturas sub-zero após 720 dias, a queda na germinação foi ainda maior. Tratamentos com $9,7 \%$ de umidade apresentaram $22 \%$ de germinação após a conservação a $-20^{\circ} \mathrm{C}$ e $60 \%$ em nitrogênio líquido. As demais umidades $(6,5 ; 5,1$ e 4,3\%) apresentaram 36, 56 e $12 \%$ respectivamente de germinação após conservação em $-20^{\circ} \mathrm{C}$ e 50 , 52 e $60 \%$ de germinação quando armazenadas em nitrogênio líquido (Tabela 3). 
Em contraste, sementes com umidade de 5,1\% não apresentaram diferenças estatísticas com o controle até 360 dias de armazenamento em nitrogênio líquido (Tabela 3).

Tabela 3: Germinação de sementes de pinhão-manso (Jatropha curcas L.) em relação aos tempos, temperaturas de armazenamento e teor de umidade das sementes

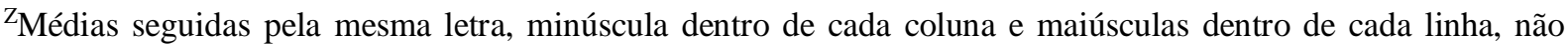
diferem pelo teste de Scott-Knott ao nível de $5 \%$ de probabilidade.

\begin{tabular}{|c|c|c|c|c|c|c|}
\hline \multicolumn{2}{|c|}{ Armazenamento } & \multicolumn{5}{|c|}{ Umidade $(\%)^{Z}$} \\
\hline Dias & $\begin{array}{c}\text { Temperatura } \\
\left({ }^{\circ} \mathrm{C}\right)\end{array}$ & 15,4 & 9,7 & 6,5 & 5,1 & 4,3 \\
\hline $\begin{array}{c}0 \\
\text { (Controle) }\end{array}$ & 25 & $82,0 \pm 2,0 \mathrm{aA}$ & $86,0 \pm 4,0 \mathrm{aA}$ & $80,0 \pm 3,0 \mathrm{aA}$ & $82,0 \pm 2,0 \mathrm{aA}$ & $82,0 \pm 2,0 \mathrm{aA}$ \\
\hline \multirow{4}{*}{180} & 25 & $0,0 \pm 0,0 \mathrm{dE}$ & $58,0 \pm 7,0 \mathrm{cB}$ & $68,0 \pm 6,0 \mathrm{bA}$ & $48,0 \pm 4,0 \mathrm{cC}$ & $38,0 \pm 6,0 \mathrm{eD}$ \\
\hline & 6 & $48,0 \pm 4,0 \mathrm{bB}$ & $74,0 \pm 4,0 \mathrm{bA}$ & $74,0 \pm 4,0 \mathrm{bA}$ & $68,0 \pm 5,0 \mathrm{bA}$ & $56,0 \pm 2,0 \mathrm{cB}$ \\
\hline & -20 & $52,0 \pm 6,0 \mathrm{bC}$ & $78,0 \pm 2,0 \mathrm{bA}$ & $70,0 \pm 4,0 \mathrm{bB}$ & $86,0 \pm 4,0 \mathrm{aA}$ & $80,0 \pm 3,0 \mathrm{aA}$ \\
\hline & NL & $40,0 \pm 3,0 \mathrm{cD}$ & $56,0 \pm 2,0 \mathrm{cC}$ & $74,0 \pm 2,0 \mathrm{bB}$ & $86,0 \pm 4,0 \mathrm{aA}$ & $82,0 \pm 4,0 \mathrm{aA}$ \\
\hline \multirow{4}{*}{360} & 25 & $0,0 \pm 0,0 \mathrm{dD}$ & $56,0 \pm 4,0 \mathrm{cB}$ & $56,0 \pm 4,0 \mathrm{cB}$ & $66,0 \pm 4,0 \mathrm{bA}$ & $32,0 \pm 2,0 \mathrm{eC}$ \\
\hline & 6 & $0,0 \pm 0,0 \mathrm{dC}$ & $76,0 \pm 5,0 \mathrm{bA}$ & $70,0 \pm 4,0 \mathrm{bA}$ & $34,0 \pm 4,0 \mathrm{eB}$ & $70,0 \pm 3,0 \mathrm{bA}$ \\
\hline & -20 & $0,0 \pm 0,0 \mathrm{dD}$ & $56,0 \pm 2,0 \mathrm{cB}$ & $70,0 \pm 6,0 \mathrm{bA}$ & $60,0 \pm 4,0 \mathrm{cB}$ & $38,0 \pm 2,0 \mathrm{eC}$ \\
\hline & NL & $36,0 \pm 4,0 \mathrm{cC}$ & $56,0 \pm 2,0 \mathrm{cB}$ & $50,0 \pm 3,0 \mathrm{cB}$ & $82,0 \pm 4,0 \mathrm{aA}$ & $46,0 \pm 2,0 \mathrm{~dB}$ \\
\hline \multirow{4}{*}{720} & 25 & $0,0 \pm 0,0 \mathrm{~dB}$ & $40,0 \pm 4,0 \mathrm{dA}$ & $34,0 \pm 2,0 \mathrm{dA}$ & $44,0 \pm 2,0 \mathrm{dA}$ & $34,0 \pm 2,0 \mathrm{eA}$ \\
\hline & 6 & $0,0 \pm 0,0 \mathrm{dC}$ & $68,0 \pm 4,0 \mathrm{bA}$ & $74,0 \pm 2,0 \mathrm{bA}$ & $72,0 \pm 4,0 \mathrm{bA}$ & $60,0 \pm 2,0 \mathrm{cB}$ \\
\hline & -20 & $0,0 \pm 0,0 \mathrm{dE}$ & $22,0 \pm 2,0 \mathrm{eC}$ & $36,0 \pm 2,0 \mathrm{~dB}$ & $56,0 \pm 2,0 \mathrm{cA}$ & $12,0 \pm 2,0 \mathrm{fD}$ \\
\hline & NL & $0,0 \pm 0,0 \mathrm{dC}$ & $60,0 \pm 3,0 \mathrm{cB}$ & $50,0 \pm 4,0 \mathrm{cB}$ & $52,0 \pm 2,0 \mathrm{cB}$ & $60,0 \pm 3,0 \mathrm{cB}$ \\
\hline
\end{tabular}

O teor de umidade de uma semente no processo de conservação é importante para estabilidade e manutenção da germinação durante o período em que elas serão armazenadas, interferindo, juntamente com a temperatura do local de conservação, no tempo em que essas sementes podem ser conservadas (PRITCHARD e NADARAJAN, 2008).

Segundo ALVES et al. (2008), de uma maneira geral, dependendo das condições ambientais e das características das próprias sementes, a deterioração pode se dar de forma muito rápida ou ser consideravelmente retardada. E, entre as diversas técnicas estudadas na busca de condições ideais de armazenamento, a principal ainda é a redução do seu metabolismo, tanto por meio da remoção de água, como pela diminuição da temperatura do ambiente de armazenamento.

De acordo com Villela e Peres (2004), sementes armazenadas com umidades acima de $10 \%$, além de manterem seu metabolismo acelerado, consumindo de forma rápida suas reservas, ainda podem sofrerem ação de microrganismos, sendo condições de ambiente seco e frio mais favoráveis ao armazenamento das sementes, especialmente as ortodoxas. 
A queda na germinação se sementes de pinhão-manso, observada nesse trabalho, também pode estar relacionada ao alto teor de lipídios encontrado nas sementes. Vários autores relatam que sementes oleaginosas são difíceis de se conservar, quando comparadas com sementes ricas em amido (BONNER, 1990; PENCE, 1990; VÁZQUEZ e ARÉCHIGA, 1996; GAGLIARDI et al., 2003; PEREIRA et al., 2013). Isso deve-se ao fato de que lipídios são quimicamente instáveis, sendo a peroxidação lipídica uma das principais causas da deterioração de sementes oleaginosas. Esse fato leva a uma cascata de acontecimentos, inicialmente pela desestruturação do sistema de membranas e, posteriormente, pelo ataque aos constituintes químicos por radicais livres, que promovem mudanças nos sistemas de membranas e atividade de biossíntese, redução na velocidade de germinação e, consequentemente, no potencial de armazenamento das sementes (CHANDEL et al., 1995; SATTLER et al., 2004).

Ainda de acordo com Crane et al. (2003) e Volk et al. (2006), sementes com conteúdo elevado de óleo são mais suscetíveis a injúrias e danos físicos causados por exposições a baixas temperaturas. Segundo os autores, baixas temperaturas podem cristalizar lipídeos durante a conservação das sementes. Portanto, no momento do congelamento, espera-se que ocorra interação entre o conteúdo de água e de óleo das sementes, quanto à viabilidade, embora as razões dessa interação ainda não sejam conhecidas.

Zonta et al. (2014), avaliando o armazenamento de sementes de pinhão-manso em diferentes embalagens e ambientes, recomendam que a conservação de pinhão-manso por tempo superior a 200 dias seja feita em baixas temperaturas, de preferência em ambientes refrigerados. Goldfarb et al. (2010), estudando o efeito da crioarmazenamento de sementes de pinhão-manso por até 90 dias, verificaram percentagem de germinação de $63 \%$, não havendo diferença estatística entre os tempos de conservação e as temperaturas de armazenamento (-170 e $\left.-196^{\circ} \mathrm{C}\right)$. Entretanto, segundo os autores, a análise por apenas três períodos de crioarmazenamento, sendo o último período de 90 dias, foram insuficientes para avaliações conclusivas sobre o comportamento das sementes. Os mesmos autores sugerem prolongar o período de criopreservação para se ter uma análise mais detalhada sobre a qualidade das sementes nessas condições de armazenamento, pois, diversos trabalhos de conservação de oleaginosas apontam um decréscimo na taxa de germinação com o prolongamento do tempo de armazenamento.

Alguns autores sugerem que sementes de pinhão-manso são ortodoxas (DENG et al., 2008; SILVA et al., 2012). No entanto, outros autores também relataram uma perda de até 50\% de viabilidade das sementes, após armazenamento em baixa temperatura durante 15 meses 
(JOKER e JEPSEN 2003). De acordo com Roberts (1973), sementes ortodoxas se mantém viáveis após a dessecação até um grau de umidade em torno de 5\% e podem ser armazenadas sob baixas temperaturas por um longo período de tempo. Entretanto, nesse trabalho foi possível verificar que sementes de pinhão-manso toleram o armazenamento por 360 dias, mantendo índices de germinação acima de $80 \%$, quando conservadas com umidade de 5,1\% em nitrogênio líquido $\left(-196^{\circ} \mathrm{C}\right)$ e descongeladas rapidamente. Porém, uma queda de mais de $40 \%$ é observada nesses tratamentos quando as sementes são conservadas por 720 dias.

Segundo Ellis (1996) existem sementes que podem ser classificadas como intermediárias, pois apresentam um comportamento de armazenamento intermediário ao ortodoxo e ao recalcitrante. De acordo com Hong e Ellis (1996) esse tipo de sementes toleram a desidratação, mas não toleram baixas temperaturas durante longos período de armazenamento. E, uma característica importante relacionada às sementes intermediárias de origem tropical é a perda da sua longevidade, quando armazenada em temperatura abaixo de $10^{\circ} \mathrm{C}$ (ELLIS et al., 1990; HONG e ELLIS, 1992).

Desta forma, de acordo com os resultados obtidos nesse trabalho, sementes de pinhãomanso deveriam ser classificadas como intermediárias, pois apesar de tolerarem baixos níveis de umidade, demonstram sensibilidade à baixa temperatura de armazenamento quando armazenadas por longos períodos. 


\subsubsection{Teste de condutividade elétrica}

Os resultados do teste de condutividade elétrica para avaliação da qualidade das sementes de pinhão-manso armazenadas com diferentes umidades e em diferentes temperaturas por até 720 dias se encontram na Tabela 4.

Tabela 4: Condutividade elétrica em sementes de pinhão-manso (Jatropha curcas L.) armazenadas com diferentes umidades e em diversas temperaturas por até 720 dias

\begin{tabular}{|c|c|c|c|c|c|c|}
\hline \multicolumn{7}{|c|}{ Condutividade Elétrica $\left(\mu \mathrm{S} . C M^{-1} \cdot \mathrm{G}^{-1}\right)$} \\
\hline \multicolumn{2}{|c|}{ Armazenamento } & \multicolumn{5}{|c|}{ Umidade (\%) } \\
\hline $\begin{array}{c}\text { Período } \\
\text { (dias) }\end{array}$ & $\begin{array}{c}\text { Temperatura } \\
\left({ }^{\circ} \mathrm{C}\right)\end{array}$ & 15,4 & 9,7 & 6,5 & 5,1 & 4,3 \\
\hline Controle & 25 & $350,0 \pm 23,0 \mathrm{dA}$ & $154,0 \pm 15,0 \mathrm{cB}$ & $148,6 \pm 10,0 \mathrm{bB}$ & $189,8 \pm 21,0 \mathrm{bB}$ & $169,0 \pm 25,0 \mathrm{bB}$ \\
\hline \multirow{4}{*}{180} & 25 & $485,2 \pm 24,0 \mathrm{cA}$ & $295,8 \pm 31,0 \mathrm{bB}$ & $203,0 \pm 15,0 \mathrm{bB}$ & $420,0 \pm 46,0 \mathrm{aA}$ & $312,0 \pm 29,0 \mathrm{aB}$ \\
\hline & 6 & $266,8 \pm 31,0 \mathrm{dA}$ & $275,4 \pm 32,0 \mathrm{bA}$ & $258,2 \pm 23,0 \mathrm{bA}$ & $156,0 \pm 8,0 \mathrm{bA}$ & $217,4 \pm 11,0 \mathrm{bA}$ \\
\hline & -20 & $444,8 \pm 229,0 \mathrm{cA}$ & $169,6 \pm 14,0 \mathrm{cB}$ & $203,4 \pm 6,0$ bB & $211,8 \pm 23,0 \mathrm{bB}$ & $232,2 \pm 8,0 \mathrm{bB}$ \\
\hline & NL & $243,4 \pm 12,0 \mathrm{dA}$ & $177,4 \pm 17,0 \mathrm{cA}$ & $234,8 \pm 3,0 \mathrm{bA}$ & $297,4 \pm 48,0 \mathrm{aA}$ & $228,0 \pm 28,0 \mathrm{bA}$ \\
\hline \multirow{4}{*}{360} & 25 & $828,0 \pm 38,0 \mathrm{aA}$ & $330,6 \pm 22,0 \mathrm{bB}$ & $302,0 \pm 15,0 \mathrm{bB}$ & $301,0 \pm 21,0 \mathrm{aB}$ & $284,2 \pm 20,0 \mathrm{aB}$ \\
\hline & 6 & $557,2 \pm 65,0 \mathrm{bA}$ & $231,0 \pm 32,0 \mathrm{bB}$ & $230,6 \pm 14,0 \mathrm{bB}$ & $244,0 \pm 29,0 \mathrm{bB}$ & $196,8 \pm 20,0 \mathrm{bB}$ \\
\hline & -20 & $650,0 \pm 51,0 \mathrm{bA}$ & $285,2 \pm 54,0 \mathrm{bC}$ & $397,8 \pm 47,0 \mathrm{aC}$ & $255,0 \pm 7,0 \mathrm{bC}$ & $479,4 \pm 47,0 \mathrm{aB}$ \\
\hline & NL & $369,8 \pm 40,0 \mathrm{~dB}$ & $246,6 \pm 28,0 \mathrm{bB}$ & $473,0 \pm 96,0 \mathrm{Aa}$ & $311,6 \pm 32,0 \mathrm{aB}$ & $330,8 \pm 47,0 \mathrm{aB}$ \\
\hline \multirow{4}{*}{720} & 25 & $802,6 \pm 45,0$ aA & $741,1 \pm 90,0 \mathrm{aA}$ & $486,6 \pm 61,0 \mathrm{aB}$ & $380 \pm 24,0 \mathrm{aC}$ & $352,8 \pm 63,0 \mathrm{aC}$ \\
\hline & 6 & $667,6 \pm 83,0 \mathrm{bA}$ & $305,2 \pm 108,0 \mathrm{bC}$ & $458,2 \pm 122,0 \mathrm{aB}$ & $269,4 \pm 50,0 \mathrm{bC}$ & $374,8 \pm 89,0 \mathrm{aB}$ \\
\hline & -20 & $667,6 \pm 83,0 \mathrm{bA}$ & $332,4 \pm 32,0 \mathrm{bB}$ & $399,2 \pm 137,0 \mathrm{aB}$ & $346,6 \pm 39,0 \mathrm{aB}$ & $347,6 \pm 81,0 \mathrm{aB}$ \\
\hline & NL & $620,8 \pm 98,0 \mathrm{bA}$ & $317,8 \pm 52,0 \mathrm{bB}$ & $432,4 \pm 35,0 \mathrm{aB}$ & $376,4 \pm 32,0 \mathrm{aB}$ & $378,6 \pm 53,0 \mathrm{aB}$ \\
\hline \multicolumn{2}{|c|}{ Coeficiente de correlação } & \multicolumn{5}{|c|}{$-0,81 *$} \\
\hline
\end{tabular}

No tratamento controle (onde é avaliado apenas o efeito da dessecação) pode-se verificar que apenas as sementes com a maior umidade $(15,4 \%)$ apresentaram diferenças estatísticas entre as demais umidades $(9,7 ; 6,5 ; 5,1$ e 4,3\%), sendo está também a maior média (Tabela 4).

Em análises de condutividade elétrica, quando menor o valor da condutividade elétrica, maior é a estabilidade das membranas e a qualidade das sementes armazenadas (VIEIRA et al., 2002). Assim, pode-se observar que, mesmo sem serem armazenadas, sementes com umidade abaixo de $10 \%$ apresentam médias de condutividade menores e estatisticamente diferentes das sementes com umidades mais elevadas (Tabela 4).

Entretanto, quando foi avaliado o efeito do tempo de conservação em relação as umidades, pôde-se verificar que a partir de 360 dias de armazenamento praticamente todas as umidades apresentaram médias de condutividade elétrica superiores às do controle e também daquelas do período de 180 dias de conservação (Tabela 4). 
Resultados semelhantes foram descritos por Chaves et al. (2012) em sementes de pinhão-manso. Os autores observaram que sementes armazenadas em ambiente natural, comparativamente às armazenadas em câmara refrigerada e câmara climatizada, apresentaram maiores valores de condutividade elétrica em todos os meses de avaliações e que a lixiviação eletrolítica foi crescente ao longo do tempo. Abreu et al. (2011), também descrevem resultados semelhantes na avaliação da condutividade elétrica de sementes de girassol armazenadas sob diferentes temperaturas. Os autores relataram um decréscimo na germinação com o decorrer do período de armazenamento, em todas as temperaturas testadas. Entretanto, o armazenamento em baixa temperatura propiciou a manutenção de melhor qualidade fisiológica das sementes em relação àquelas armazenadas a $25{ }^{\circ} \mathrm{C}$, embora a redução na germinação ocorreu independentemente da temperatura de armazenamento. Pontes et al. (2006) também verificaram que os valores de condutividade elétrica foram constantes em sementes de sibipiruna (Caesalpinia peltophoroides Benth.) armazenadas à $5{ }^{\circ} \mathrm{C}$. Porém, naquelas que permaneceram em ambiente a $20{ }^{\circ} \mathrm{C}$ houve aumento significativo da condutividade elétrica durante o período de armazenamento. Resultados semelhantes obtidos para sementes de soja indicam que a quantidade de íons lixiviados pelas sementes é influenciada pela temperatura de armazenamento (VIEIRA et al., 2001; PANOBIANCO e VIEIRA, 2007).

A relação entre o teste de condutividade elétrica e a taxa de germinação foi calculada por teste de correlação, tendo sido determinado um coeficiente de correlação linear de $-0,81$ (correlação negativa forte) (Tabela 4). Assim, verifica-se que a percentagem de germinação das sementes de pinhão-manso é inversamente proporcional ao resultado da condutividade elétrica. Esse resultado corrobora os dados apresentado nas Tabela 3, onde os tratamentos com menores valores de eletrólitos lixiviados apresentaram maior taxa de germinação.

\subsection{Criopreservação de eixos embrionários de pinhão-manso}

\subsubsection{Determinação da curva de dessecação}

Após 60 minutos de hidratação, os eixos embrionários apresentavam 61,7\% de umidade, A queda da umidade de acordo com o tempo de exposição ao fluxo de ar foi evidente, sendo que após 2 horas de dessecação os eixos embrionários já apresentavam umidade de 41,3\%, caindo para 27,3; 16,8; 9,4 e 7,6\% após 4, 6, 8 e 10 horas de dessecação em fluxo de ar, respectivamente (Figura 2). 
Nos eixos embrionários a dessecação influenciou a germinação, sendo que apenas os tratamentos com 9,4 e 7,6\% de umidade apresentaram médias de germinação acima de 90\%, estatisticamente diferente das demais (Tabela 5)

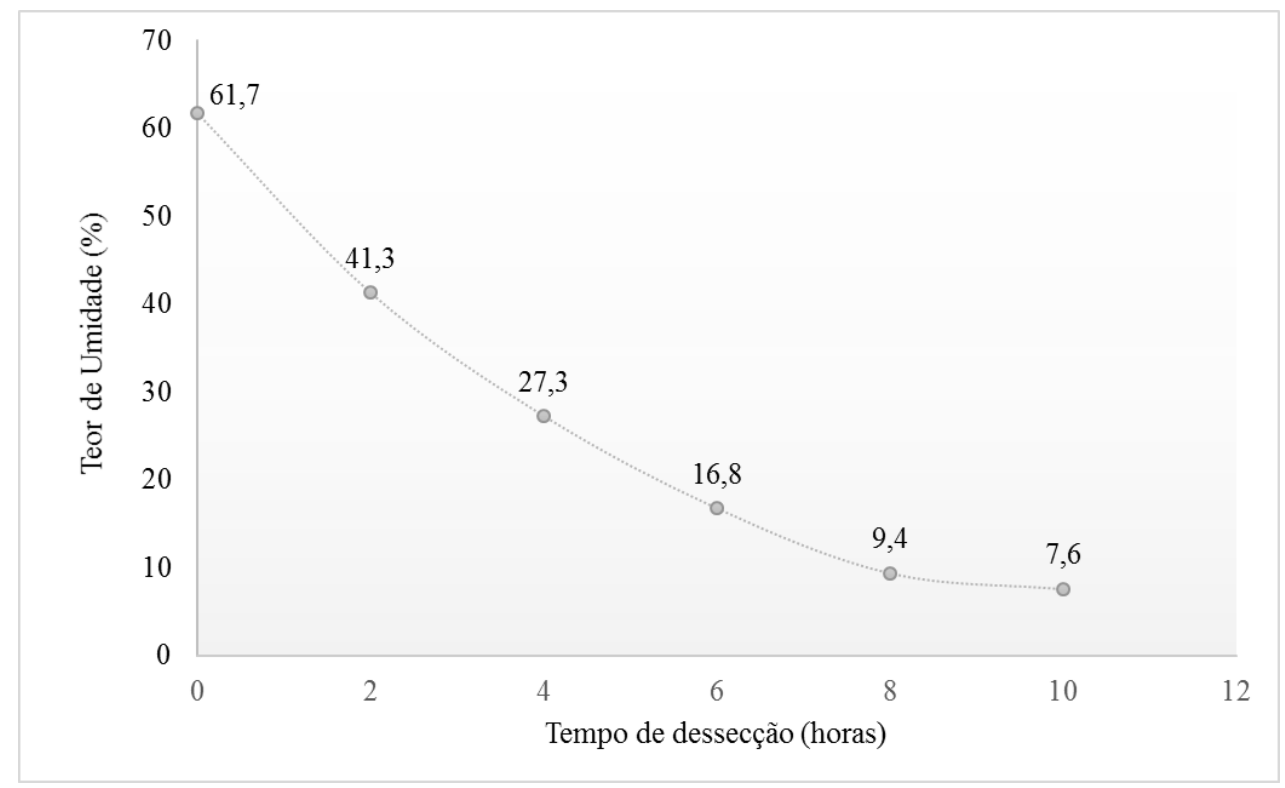

Figura 2. Curva de umidade de eixos embrionários de pinhão-manso (Jatropha curcas L.) em resposta ao tempo de dessecação em câmara de fluxo laminar.

Tabela 5. Germinação de eixos embrionários de pinhão-manso (Jatropha curcas L) em função do teor de umidade $\mathrm{z}$.

\begin{tabular}{cc}
\hline Teor de umidade (\%) & Germinação $(\%)$ \\
\hline 61,7 & $52,0 \pm 6,0 \mathrm{c}$ \\
41,3 & $62,0 \pm 3,0 \mathrm{c}$ \\
27,3 & $50,0 \pm 4,0 \mathrm{c}$ \\
16,8 & $77,7 \pm 5,0 \mathrm{~b}$ \\
9,4 & $92,0 \pm 3,0 \mathrm{a}$ \\
7,6 & $92,0 \pm 5,0 \mathrm{a}$ \\
\hline
\end{tabular}

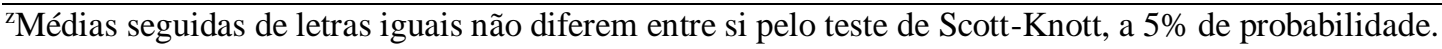

Prada et al. (2015) também avaliaram o efeito da dessecação de eixos embrionários de pinhão-manso, expostos ao fluxo de ar por 0, 30 e 60 minutos. Os autores verificaram que as umidades avaliadas foram de 11,6, 9,7 e 9,4\%, respectivamente, e não houve diferenças estatísticas quanto a germinação, que alcançou $100 \%$.

Quando comparado a umidade dos eixos embrionários com o tempo de criopreservação fica evidente a importância da dessecação do material a ser conservado (Figura 3). Os tratamentos com maiores umidades (61,7 e 41,4 \%) não germinaram, após a exposição ao nitrogênio líquido. Já eixos com 27,3\% de umidade apresentaram cerca de 50\% de germinação, por até 180 dias de criopreservação, enquanto que após 360 dias de exposição ao nitrogênio líquido a taxa de germinação caiu para zero (Figura 3). 
No tratamento onde os eixos apresentavam 16,8\% de umidade, verificou-se taxas de germinação de $77,5 \%$ sem exposição ao nitrogênio líquido. Porém, após 2 dias de criopreservação, a germinação caiu para $50 \%$ e para cerca de $30 \%$ nos demais tempos de armazenamento (Figura 3). Já os tratamentos onde os eixos foram criopreservados com umidades de 9,4 e 7,6\%, índices superiores a 90\% de germinação foram observados, independentemente do tempo de armazenamento, não havendo diferenças estatísticas entre os tratamentos expostos ao nitrogênio líquido e o controle (Figura 3).

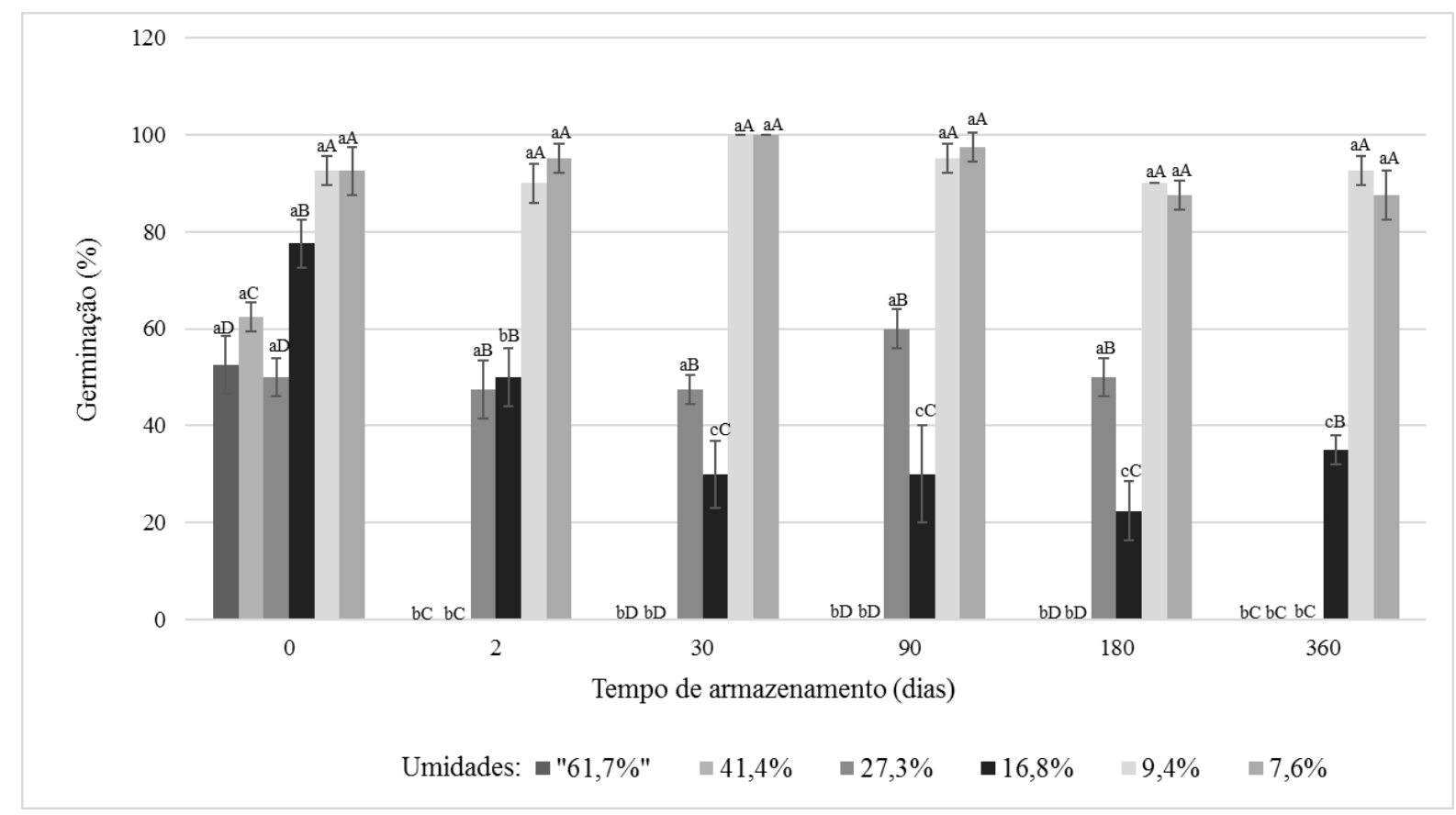

Figura 3: Germinação dos eixos embrionários de pinhão-manso (Jatropha curcas L.) com diferentes umidades durante $\mathrm{o}$ armazenamento por até 360 dias.

${ }^{\mathrm{Z}}$ Médias seguidas pela mesma letra minúscula entre os tempos de armazenamento e maiúsculas as umidades, não diferem pelo teste de Scott-Knott ao nível de 5\% de probabilidade.

Em 1991, Engelmann destacou a importância de desidratação artificial de explantes antes da exposição ao nitrogênio líquido. Segundo o autor, a diminuição da quantidade de água no explante é importante para o protege-lo de possíveis danos causados pela cristalização intracelular de água em gelo durante a regeneração. Os dados observados nesse trabalho corroboram com essa informação, uma vez que eixos embrionários com menos de $10 \%$ de umidade apresentaram mais de $90 \%$ de germinação, após a exposição ao nitrogênio líquido.

Segundo Berjak e Pammenter (2008), a criopreservação de embriões e eixos embrionários excisados têm gerado resultados promissores na conservação de espécies. Segundo estes, o eixo embrionário possui uma menor área em relação a semente, o que permite 
uma rápida perda de água, bem como um congelamento mais rápido quando o material é exposto ao nitrogênio líquido, evitando, assim, a formação de cristais de gelo.

Outra vantagem do uso de eixos embrionários ou embriões zigóticos é que em sementes oleaginosas, como no caso do pinhão-manso, o alto teor de lipídios encontrado na semente, principalmente no endosperma, pode ocasionar uma perda de viabilidade destas quando armazenadas por longos períodos, mesmo em temperaturas sub-zero (NORMAH e MAKEEN, 2008). Segundo Crane et al. (2003 e 2006), assim como a água, ao ser exposto a temperaturas extremamente baixas, como as provocadas pelo nitrogênio líquido, tanto os lipídios livres na célula, quanto aqueles estruturais, podem ser cristalizados e virem a provocar danos estruturais nas membranas celulares, além da liberação de radicais livres e geração de substâncias toxicas as células. Em amendoim (Arachis hypogaea), o problema da perda de viabilidade das sementes durante a criopreservação a longo prazo foi resolvido utilizando a técnica de criopreservação dos eixos embrionários (GAGLIARDI et al., 2003).

No caso da conservação de germoplasma de pinhão-manso, informações sobre a fisiologia e conservação de sementes permanece limitada, com resultados ainda controversos. Para alguns autores (JOKER e JEPSEN, 2003; TORAL et al., 2008), as sementes da espécie não podem ser armazenadas por mais de 15 meses. Já para Verma e Gaur (2009), a alegação é de que estas sementes são ortodoxas e, como tal, podem ser armazenadas com baixo teor de umidade, apesar do seu alto teor de óleo comprometer o armazenamento a longo prazo.

No experimento descrito anteriormente com sementes, foi visto que sementes de pinhãomanso parecem apresentar comportamento intermediário durante a conservação. Sendo assim, a criopreservação de eixos embrionários se torna a opção mais indicada uma vez que estes toleraram a dessecação e mantem as taxas de germinação acima de $90 \%$ quando expostos ao nitrogênio líquido. 


\section{CONCLUSÕES}

Com os resultados obtidos neste trabalho, pode-se concluir que:

- O processo de dessecação das sementes de pinhão-manso em sílica-gel não interfere na viabilidade das sementes não armazenadas;

- As sementes de pinhão-manso toleram a dessecação, se mantendo viáveis com umidade de até $4,3 \%$. Porém, não toleram o armazenamento por até 720 dias em baixas temperaturas $\left(6^{\circ} \mathrm{C}\right)$, temperaturas sub-zer $\left(-20^{\circ} \mathrm{C}\right.$ e nitrogênio líquido) e temperatura ambiente $\left(25^{\circ} \mathrm{C}\right)$,

- Sementes de pinhão-manso se mantem viáveis por até 360 dias apenas quando armazenadas com umidade de 5,1\% e conservadas em nitrogênio líquido;

- O teste de condutividade elétrica se mostra eficaz na avaliação da qualidade das sementes de pinhão-manso conservadas por longos períodos, podendo ser uma medida de correlação para analisar a qualidade das sementes quanto ao potencial de germinação;

- As sementes de pinhão-manso toleraram a dessecação, porém não suportaram a conservação por 720 dias, mesmo em temperaturas sub-zero, sugerindo apresentarem comportamento intermediário e,

- Para a conservação de pinhão-manso, a criopreservação de eixos embrionários é a técnica mais indicada, pois garante a viabilidade dos eixos embrionários em mais de 90\%, após 360 dias de conservação. 


\section{REFERÊNCIAS BIBLIOGRÁFICAS}

ABREU, L.A.S., CARVALHO, M.L.M., PINTO, C.A.G. e KATAOKA, V.Y. Teste de condutividade elétrica na avaliação de sementes de girassol armazenadas sob diferentes temperaturas. Revista Brasileira de Sementes, v. 33, n. 4 p. 635 - 642, 2011.

ALMEIDA, F.A.C., JERÔNIMO, E.S., ALVES, N.M.C., GOMES, J.P e, SILVA, A.S. Estudo de técnicas para o armazenamento de cinco oleaginosas em condições ambientais e criogênicas. Revista Brasileira de Produtos Agroindustriais, Campina Grande, v.12, n.2, p.189-202, 2010.

ALVES, E.U., SILVA, K.B., BRUNO, R.L.A., ALVES, A.U., CARDOSO, E.A., GONÇALVES, E.P.e BRAZ, M.S.S. Comportamento fisiológico de sementes de pitombeira [Talisia esculenta (A. ST. Hil) Radlk] submetidas à desidratação. Revista Brasileira de Fruticultura, Jaboticabal, v. 30, n. 2, 2008.

ARRUDA, F.P., BELTRÃO, N.E. De M., ANDRADE, A.P., PEREIRA, W.E. e SEVERINO, L.S. Cultivo de pinhão-manso (Jatropha curcas L.) como alternativa para o Semi-Árido nordestino. Revista Brasileira de Oleaginosas e Fibrosas, v.8, p. 789-799, 2004.

BELTRÃO, N.E.M. e CARTAXO, W.V. Considerações gerais sobre o pinhão-manso (Jatropha curcas L.) e a necessidade urgente de pesquisas, desenvolvimento e inovações tecnológicas para esta planta nas condições brasileiras. Embrapa Algodão, Campina GrandePB, n. 98, p. 4, 2006.

BENSON, E. E., DUMET, D. J., e HARDING, K. Cryopreservation of plant cells, tissues and organs. Encyclopedia of cell technology, 2000.

BERJAK, P e PAMMENTER N.W. From Avicennia to Zizania: seed recalcitrance in perspective. Annals of Botany, v. 101, p. 213-228, 2008.

BONNER, F.T. Storage of seeds: Potential and limitations for germplasm conservation. Forest Ecology and Management, v.35, p. 35-43, 1990.

BRASIL. Ministério da agricultura, Pecuaria e Abastecimento. Regras para análises de sementes. Secretaria de Defesa Agropecuária. Brasília, 365 p, 2009.

BRASIL. Ministério da Indústria e do Comércio. Secretária de Tecnologia Industrial. Produção de combustíveis líquidos a partir de óleos vegetais. Brasília: STI/CIT, 1985. 364p. (Documentos, 16).

CARELS, N. Jatropha curcas: A Review. Advances in Botanical Research, v. 50, p. 39 - 86, 2009.

CARNIELLI, F. O combustível do futuro. 2003.

CARVALHO, N. M.; NAKAGAWA, J. Germinação de sementes. In: CARVALHO, N.M., NAKAGAWA, J. Sementes: ciência, tecnologia e produção. 4.ed. Jaboticabal: FUNEP, 2000. p. 128-166. 
CHANDEL, K.P.S., CHAUDHURY, R., RADHAMANI, L. e MALIK, K. desiccation and freezing sensitivity in recalcitrant seeds of Tea, Cocoa and Jackfruit. Annuals of Botany, v. 76, p. 443-450, 1995.

CHAUDHURY, R e CHANDEL, K.P.S. Cryopreservation of embryonic axes of almond (Prunus amygdalus Batsch.) seeds. CryoLetters, v.16, p. 51 - 56, 1995.

CHAVES, T.H., RESENDE, O., SIQUEIRA, V.C. e ULLMANN, R. Qualidade fisiológica das sementes de pinhão-manso (Jatropha curcas L.) durante o armazenamento em três ambientes. Semina: Ciências Agrárias, v. 33, n. 5, p. 1653-1662, 2012.

CHIN, H.F. Seed banks: Conservation of the past for the future. Seed Science Technology, v. 22, p. $385-400,1994$.

CHMIELARZ, P. Cryopreservation of dormant orthodox seeds of forest trees: mazzard cherry (Prunus avium L.). Annals of forest science, v. 66, n. 4, p. 1-9, 2009.

CRANE, J., KOVACH, D., GARDNER, C., e WALTERS, C. Triacylglycerol phase and 'intermediate'seed storage physiology: a study of Cuphea carthagenensis. Planta, v. 223, n. 5, p. 1081-1089, 2006.

CRANE, J., MILLER, A.L., VAN ROEKEL, J.W. e WALTERS, C.W. Triacylglycerols determine the unusual storage physiology of Cuphea seed. Planta, v.217, p. 699-708. 2003.

CROWE, J. H., CARPENTER, J. F., CROWE, L. M., e ANCHORDOGUY, T. Are freezing and dehydration similar stress vectors? A comparison of modes of interaction of stabilizing solutes with biomolecules. Cryobiology, v. 27, n. 3, p. 219-231, 1990.

DENG, Z.J., XIANG, Z.Y., CHENG, H.Y., LI, Y.J. e SONG, S.Q. Preliminary Study on Development, Germination and Desiccation Tolerance of Jatropha curcas (Euphorbiaceae). Acta Botanica Yunnanica, v. 30, p. 355-359. 2008.

ELLIS, R. H., HONG, T. D. e ROBERTS, E. H. An intermediate category of seed storage behaviour? I. Coffee. Journal of Experimental Botany, v. 41, n. 9, p. 1167-1174, 1990.

ENGELMANN, F. In vitro conservation of tropical plant germplasm - a review. Euphytica, v. 57, n. 3, p. 227-243, 1991.

ENGELMANN, F. Use of biotechnologies for the conservation of plant biodiversity. In Vitro Cellular e Developmental Biology - Plant, v.47, p. 5-16, 2011.

FONSECA, A.G., MATUDA, J.J., ALMEIDA, J.O., NUNES, U.R. e MACHADO, E.L.M. Qualidade fisiológica de sementes de Pinus elliotti Engelm submetidas a diferentes métodos de armazenamento. Cerne, Lavras, v. 18, n. 3, p. 457-463, 2012.

GAGLIARDI, R.F., PACHECO, G.P., CAMEIRO, L.A., VALLS, J.F.M., VIEIRA, M.L.C. e MANSUR, E. Cryopreservation of Arachis species by vitrification of in vitro grown shoot apices and genetic stability of recovered plants. CryoLetters, v. 24, p, 103 -110, 2003. 
GOLDFARB, M., DUARTE, M.E.M. e MATA, M.E.R.M.C. Armazenamento criogênico de sementes de pinhão-manso (Jatropha curcas L.) Euphorbiaceae. Biotemas, v. 23, p.27-33, 2010.

GOLDFARB, M., MARTINS, M.E.D., CAVALCANTI MATA, M.E.R.M., PIMENTEL, L.W. e SEVERINO, L.S. Teor de água limite para crioconservação das sementes de pinhão-manso (Jatropha curcas L.). Revista Brasileira de Produtos Agroindustriais, v. 10, n. 02, p. 121129, 2008.

HONG, T. D. e ELLIS, R. H. A protocol to determine seed storage behaviour. Bioversity International, 1996.

HORING, C. F., MALAVASI, M. M. e MALAVASI, U. C. Armazenamento não controlado na qualidade de sementes de Jatropha curcas L. Semina: Ciências Agrárias, Londrina, v. 32, n. 2, p. 521-526, 2011.

JØKER, D e J. JEPSEN. Jatropha curcas L. Seed leaflet, n. 83. Danida Forest Seed Centre. Denmark. 2003.

KARTHA, K.K. Meristem culture and germplasm preservation. In: Kartha, K.K. (Ed.) Cryopreservation of plant cells and organs. Boca Raton, Florida, CRC Press, pp. 115-134. 1985.

MARIN, M. L., MAFLA, G., ROCA, W. M., e WITHERS, L. A.Cryopreservation of cassava zygotic embryos and whole seeds in liquid nitrogen. Cryo-letters, v. 11, n. 4, p. 257-264, 1990.

MOTTA, L. B., LOPES, J. C., ZANOTTI, R. F., BERNARDES, P. M., e DA SILVA, J. A. Cryostorage of sunflower seeds. Bioscience Journal, v. 30, n. 2, 2013.

MUKHERJEE, P., VARSHNEY, A., JOHNSON, T.S., e JHA, T.B. Jatropha curcas: A Review on Biotechnological Status and Challenges, Plant Biotechnology Reports. 2011.

MURASHIGE, T. e SKOOG, F. A revised medium for rapid growth and biossays with tobacco tissue cultures. Physiologia Plantarum., 15: 473-497, 1962.

NORMAH, M.N. e MAKEEN, A.M. Cryopreservation of Excised Embryos and Embryonic Axes. . In: Reed, B.M. Plant Cryopreservation: A Practical Guide. Springer Science, 211-240, 2008.

NUNES, C.F., SANTOS, D.N., PASQUAL, M. e VALENTE, T.C.T. Morfologia externa de frutos, sementes e plântulas de pinhão-manso. Pesquisa Agropecuária Brasileira, v. 44, n. 2, P. 207-210, 2009.

OPENSHAW, K. A review of Jatropha curcas: an oil plant of unfulfilled promise. Biomass e Bioenergy, n. 19, p. 1-15, 2000.

PANDEY, V.C., SINGH, K., SINGH, J.S., KUMAR, A., SINGH, B. e SINGH, R.P. Jatropha curcas: a potential biofuel plant for sustainable environmental development. Renewable e Sustainable Energy Reviews, v. 16, n. 15, p. 2870-2883, 2012. 
PANOBIANCO, M. e VIEIRA, R.D. Electrical conductivity and deterioration of soybean seeds exposed to different storage conditions. Revista Brasileira de Sementes, v.29, n.2, p.97-105, 2007.

PENCE, V.C. Cryostorage of embryo axes of several large-seeded temperate tree species. Cryobiology, v. 27, p. 212-218, 1990.

PEREIRA, M.D., DIAS, D.C.F.S., BORGES, EE.L., MARTINS FILHO, S., DIAS, L.A.S. e SORIANO, P.E. Physiological quality of physic nut (Jatropha curcas L.) seeds during storage. Journal of Seed Science, v.35, n.1, p.21-27, 2013.

PINTO JUNIOR, A.S., GUIMARÃES, V.F., DRANSKI, J.A.L., STEINER, F., MALAVASI, M.M. e MALAVASI, U.C. Armazenamento de sementes de pinhão-manso em diferentes embalagens e ambientes. Revista Brasileira de Sementes, v. 34, n.4, p. 636-643. 2012.

PONTES, C.A., CORTE, V.B., BORGES, E.E.L., SILVA, A.G. e BORGES, R.C.G. Influência da temperatura de armazenamento na qualidade das sementes de Caesalpinia peltophoroides Benth. (Sibipiruna). Revista Árvore, Viçosa, v.30, n.1, p.43-48, 2006.

PRADA, J.A., AGUILAR, M.E., ESQUIVEL, A.A. e ENGELMANN, F. Cryopreservation of Seeds and Embryos of Jatropha curcas L. American Journal of Plant Sciences, v. 6, p. 172$180,2015$.

PRITCHARD, H.W e NADARAJAN, J. Cryopreservation of Orthodox (Desiccation Tolerant) Seeds. In: REED, B.M. Plant Cryopreservation: A Practical Guide. Springer Science, p. 485-501, 2008.

ROBERTS H. F. Predicting the viability of seeds. Seed Science Technology, v. 1, p.499-514, 1973.

ROBERTS, E.H. e ELLIS, R.H. Water and seed survival. Annals of Botany, v. 63, p. 39 - 52. 1989.

SANTOS, I.R.I. Criopreservação: potencial e perspectivas para a conservação de germoplasma vegetal. Revista Brasileira de Fisiologia Vegetal, v. 12, p. 70-84, 2000.

SATTLER, S.E., GILLILAND, L.U., MAGALLANES-LUNDBACK, M., POLLARD, M. e DELLAPENNAA, D. Vitamin $\mathrm{E}$ is essential for seed longevity and for preventing lipid peroxidation during germination. The Plant Cell, v. 16, p. 1419 - 1432, 2004.

SATURNINO, H.M.; PACHECO, D.D.; KAKIDA, J.; TOMINAGA, N. e GONÇALVES, N.P. Cultura do pinhão-manso (Jatropha curcas L.). Informe Agropecuário, Belo Horizonte, p. 4474, 2005.

SILVA, F. de A. S. e AZEVEDO, C. A. V. de. Principal Components Analysis in the Software Assistat-Statistical Attendance. In: World congress on computers in agriculture, 7, Reno-NV-USA: American Society of Agricultural and Biological Engineers, 2009. 
SILVA, R.C., CAMILlO, J. e SCHERWINSKI-PEREIRA, J.E. A method for seedling recovery in Jatropha curcas after cryogenic exposure of the seeds. Revista de Biologia Tropical, v. 60, n. 1, p. 473-482, 2012.

SILVA, R.C., CAMILlO, J., LUIS, Z.G. e SCHERWINSKI-PEREIRA, J.E. Potencial germinativo e morfoanatomia foliar de plântulas de pinhão-manso originadas de germoplasma criopreservado. Pesquisa Agropecuária Brasileira. v.46, n. 8, p. 836-845. 2011.

SOUZA, V.C., ANDRADE, LA., CRUZ, F.R.S., FABRICANTE, J.R. e OLIVEIRA, L.S.B. Conservação de sementes de marizeiro Geoffroea spinosa Jacq. utilizando diferentes embalagens e ambientes. Ciência Florestal, Santa Maria, v. 21, n. 1, p. 93-102, 2011.

STYLES, E. D., BURGESS, J. M., MASON, C., e HUBER, B. M. Storage of seed in liquid nitrogen. Cryobiology, v. 19, n. 2, p. 195-199, 1982.

TORAL, O., IGLESIAS, J., OCA, S., SOTOLONGO, J., GARCIA, S. e TORSTI, M. Jatrpha curcas L., a Tree Species with Energetic Potential in Cuba. Pastos y Forrajes, v. 31, p. 191207. 2008.

VÁZQUEZ-YANES, C. e ARÉCHIGA, M.R. Ex situ conservation of tropical rain forest seed: problems and perspectives. Interciencia, v. 21, p. 293-298,1996.

VERMA, K. e GAUR, A. Jatropha curcas L.: Substitute for Conservation Energy. World Journal of Agricultural Sciences, v.5, p. 552-556. 2009.

VIEIRA, R.D., PENARIOL, A.L., PERECIN, D. e PANOBIANCO, M. Condutividade elétrica e teor de água inicial das sementes de soja. Pesquisa agropecuária brasileira, Brasília, v. 37, n. 9 , p. 1333-1338, 2002.

VIEIRA, R.D., TEKRONY, D.M., EGLI, D.B. e RUCKER, M. Electrical conductivity of soybean seeds after storage in several environments. Seed Science and Technology, v.29, p.599-608, 2001.

VILLELA, F.A. e PERES, W,B. Coleta, beneficiamento e armazenamento. In: FERREIRA, G.A e BORGHETTI. Germinação: do básico ao aplicado. Artimed, p. 265-281, 2004.

VOLK, G.M, CRANE, J., CASPERSEN, A.M., HILL, L.M, GARDNER, C. e WALTERS, C. Massive cellular disruption occurs during early imbibition of Cuphea seeds containing crystallized triacylglycerols. Planta, v.224, p. 1415-1426. 2006.

WALTERS, C. Orthodoxy, recalcitrance and in-between: describing variation in seed storage characteristics using threshold responses to water loss. Planta, p. 1-10, 2015.

WITHERS, L.A. e ENGELMANN, F. In vitro conservation of plant genetic resources. In: Altman A (ed) Agricultural Biotechnology (pp 57-88), Marcel Dekker, New York. 1998.

ZONTA, J.B., ARAUJO, E.F., ARAUJO, R.F., ZONTA, J.H., DIAS, L.A.S. e RIBEIRO, P.H. Armazenamento de sementes de pinhão-manso em diferentes embalagens e ambientes. Bioscience Journal, Uberlandia, v. 30, p. 599-608, 2014. 


\section{CAPÍTULO 3}

INDUÇÃO E CARACTERIZAÇÃO MORFOANATÔMICA DE CALOS PARA O DESENVOLVIMENTO DA EMBRIOGÊNESE SOMÁTICA EM PINHÃO-MANSO

(Jatropha curcas L.) 


\section{INDUÇÃO E CARACTERIZAÇÃO MORFOANATÔMICA DE CALOS PARA O DESENVOLVIMENTO DA EMBRIOGÊNESE SOMÁTICA EM PINHÃO-MANSO (Jatropha curcas L.)}

\section{RESUMO}

O objetivo do trabalho foi induzir e caracterizar morfoanatomicamente a calogênese de pinhãomanso, com vistas a desenvolver um protocolo de embriogênese somática para a espécie. Explantes de hipocótilo e folhas cotiledonares de plantas in vitro foram inoculados em meio de MS suplementado com diferentes concentrações de 2,4-D e picloram $(0,50,100,200$ e 400 $\mu \mathrm{M})$ em combinação ou não com $50 \mu \mathrm{M}$ de cinetina e mantidos em condição de luz ou escuro por 30 e 60 dias. Após os tempos de cultivo, a relação entre o número de explantes com calos foi avaliada e as características morfológicas como textura dos calos formados (friável, semicompacto e compacto) e a coloração predominante foram descritas. Análises anatômicas foram realizadas em calos com 60 dias de cultivo. Neste trabalho foi possível verificar que os explantes de pinhão-manso, constituídos por hipocótilo e folhas cotiledonares foram responsivos a indução de calos. O picloram proporcionou as maiores percentagens de explantes contendo calos em todas as condições de cultivo, os quais apresentaram característica semicompacta e friável. Já o 2,4-D foi mais eficiente na formação de calos compactos com aspecto globular. O tratamento contento apenas cinetina promoveu a formação de calos friáveis em folhas cotiledonares e calos friáveis e semi-compactos em explantes de hipocótilo. Calos brancos friáveis, mesmo sem a presença de regulador de crescimento no meio de cultura, foram evidenciados em explantes de hipocótilo. Calos com potencial embriogênico foram evidenciados nas concentrações de 200 e $400 \mu \mathrm{M}$ de picloram e 2,4-D em hipocótilos e folhas cotiledonares quando cultivados, preferencialmente, no escuro.

Palavras-chave: Jatropha cucas, auxinas, calogênese. 
INDUCTION AND MORPHOANATOMICAL CHARACTERIZATION OF CALLUS FOR DEVELOPMENT SOMATIC EMBRYOGENESIS IN PINHÃO-MANSO (Jatropha curcas L.)

\begin{abstract}
The objective was to induce and characterize regards morphology, anatomy calogenesis of pinhão-manso, in order to develop a somatic embryogenesis protocol for the species. Explants of hypocotyl and cotyledon leaves of plants in vitro were inoculated in MS medium supplemented with different concentrations of 2,4-D and Picloram (0, 50, 100, 200 and 400 $\mathrm{mM}$ ) in combination with or without $50 \mathrm{uM}$ kinetin and kept under light or dark condition for 30 to 60 days. After the cultivation time, the relationship between the number of explants and calli was measured as the morphological characteristics of the formed calli texture (crispy, compact and semi-compact), and the predominant staining were described. anatomical analyzes were performed on callus 60 days of cultivation. In this work we found that the pinhão-manso explant consisting of hypocotyl and cotyledons were responsive to callus induction. The picloram provided the greatest percentages explants containing calluses in all growing conditions, which showed semi-compact feature and crumbly. Since 2,4-D was more efficient in the formation of compact callus with a globular appearance. Treatment satisfaction only kinetin promoted the formation of friable callus in cotyledons and friable calluses and semicompact in hypocotyl explants. white friable callus even without the presence of growth regulators in the culture medium, were found in hypocotyl explants. Calli with embryogenic potential was evident at concentrations of 200 and $400 \mathrm{mM}$ of picloram and 2,4-D in hypocotyls and cotyledons when cultured, preferably in the dark.
\end{abstract}

Keywords: Jatropha cucas, auxin, callogenesis 


\section{INTRODUÇÃO}

O pinhão-manso (Jatropha curcas L.), pertencente à família Euphorbiaceae, é uma planta perene, com sementes oleaginosas, capaz de suportar condições semiáridas de cultivo e períodos de deficiência hídrica (HELLER, 1996; WINKLER et al. 1997). Com origem na América Latina, o gênero Jatropha compreende mais de 170 espécies, sendo as espécies $J$. curcas. a mais utilizadas na produção de óleo (SWARUP, 2004). As sementes de Jatropha contém cerca de 30-40\% de óleo, o qual apresenta um padrão de ácidos graxos semelhantes ao dos óleos comestíveis (GUBITZ et al. 1999). Óleo de Jatropha contém ácido linolênico e ácido oleico que, juntos, correspondem por mais de $80 \%$ da composição do óleo. O ácido palmítico e ácido esteárico são outros ácidos graxos presentes (PARAWIRA, 2010)

Tendo em vista o potencial para a produção de óleo, o pinhão-manso tem atraído atenção especial como uma planta de potencial energético, pois o óleo das sementes pode ser usado como biodiesel. De fato, o cultivo de pinhão-manso tem se mostrado importante, pois pode ser uma alternativa para atender a demanda de biodiesel e assegurar um abastecimento contínuo com matérias-primas de qualidade (DEORE et al. 2008).

A espécie é propagada por via seminal e vegetativa (SATURNINO et al. 2005). Entretanto, plantios desuniformes com uso de sementes e a alta demanda de material vegetal (estacas) têm sido apontados como alguns dos principais fatores que limitam a expansão racional da cultura (OPENSHAW et al. 2000).

Assim, pesquisas a respeito de multiplicação in vitro da espécie são imprescindíveis, seja para acelerar programas de melhoramento genético, produzir mudas de genótipos selecionados em escala comercial, ou então, permitir estudos biológicos básicos sobre a espécie (ACHTEN et al. 2010 e MUKHERJEE et al. 2011).

Diversas técnicas de propagação in vitro utilizando-se vários tipos de explantes em $J$. curcas têm sido relatados por autores (WEIDA et al. 2003; SUJATHA et al. 2005; JHA et al. 2007; DEORE et al. 2008; NHUT et al. 2013; SHUKLA et al. 2013; SIANG et al. 2014; CHIANGMAI et al. 2015; YING et al. 2015). Entretanto, apesar dos vários trabalhos encontrados na literatura, ainda não existe um protocolo confiável para a propagação in vitro da espécie, sendo observado geralmente trabalhos não reproduzíveis. Segundo Jha et al. (2007), Attaya et al. (2014) e Chiangmai et al. (2015), qualquer que seja a estratégia a ser utilizada com vistas a reprodução vegetativa de pinhão-manso, seja por cultivo de calos, organogênese e/ou embriogênese somática, os resultados são complexos devido as respostas diferenciais dos genótipos, além da falta de informação e caracterização das etapas envolvidas nesses processos. 
Ainda segundo os autores, até o momento, o que se tem observado na literatura são trabalhos de tentativa e erro que não aprofundam as metodologias utilizadas.

A formação de calos é um processo importante para a obtenção indireta de plantas em protocolos de embriogênese somática (WILLIAMS e MAHESWARAN 1986; ZIMMERMAN, 1993). E, uma vez formados, os calos geralmente contém células ou grupos de células que possuem centros ativos de divisão celular que, sob condições adequadas, podem ser estimulados para a produção de órgãos vegetativos (GEORGE, 1996; IKEUCHI et al. 2013). Ainda em 1958, Steward e colaboradores trabalhando com Daucus carota afirmaram que o calo pode ser produzido a partir de uma única célula diferenciada, e muitas células desse calo podem tornarem-se totipotentes e capazes de regenerar uma planta completa.

Assim, é evidente que para se avançar nos trabalhos com pinhão-manso é importante que, antes mesmo de se obter plantas, primeiramente se domine as diferentes etapas envolvidas no processo da embriogênese somática, a qual se inicia com escolha dos explantes a serem cultivados, bem como com a indução de calos propriamente dita (ZIMMERMAN, 1993 e FRANK et al. 2000; IKEUCHI et al. 2013).

Neste contexto, o principal objetivo do trabalho foi induzir e caracterizar morfoanatomicamente a calogênese de pinhão-manso, com vistas a desenvolver um protocolo de embriogênese somática para a espécie. Mais especificamente, o trabalho avaliou tipos de explantes e combinações de reguladores de crescimento, bem como caracterizou os diferentes tipos de formação obtidos em função do tempo e condições de cultivo. 


\section{MATERIAL E MÉTODOS}

\subsection{Local da realização dos experimentos}

Os estudos foram conduzidos no Laboratório de Cultura de Tecidos II da Embrapa Recursos Genéticos e Biotecnologia, Brasília, DF.

As sementes de pinhão-manso utilizadas nos experimentos foram obtidas de amostras do acesso 115-I-1 do Banco Ativo de Germoplasma de pinhão-manso (BAG-Pinhão-manso), localizado no Campo Experimental da Embrapa Cerrados, em Planaltina - DF.

\subsection{Obtenção de plantas matrizes}

Para obtenção das plantas matriz doadoras de explantes, sementes foram lavadas em água corrente, sendo realizada a remoção do tegumento com o auxílio de alicate. Em seguida, as sementes sem tegumento foram desinfestadas por meio de imersão em álcool (70\%) por 1 minuto e solução de hipoclorito de sódio ( $6 \%$ de cloro ativo) por 30 minutos, em câmara de fluxo laminar. Após, a desinfestação foi completada pela lavagem das sementes por três vezes em água destilada autoclavada, tendo cada lavagem duração de 3 minutos.

As sementes devidamente desinfestadas foram inoculadas em tubos de ensaio ( 15 x 150 $\mathrm{mm}$ ) contendo $10 \mathrm{~mL}$ de meio de MS (MURASHIGE \& SKOOG, 1962), acrescido de $30 \mathrm{~g} / \mathrm{L}$ de sacarose, 2,5 g/L de Phytagel ${ }^{\circledR}$, sendo mantidas por 30 dias em sala de crescimento à temperatura de $25 \pm 2{ }^{\circ} \mathrm{C}$, fotoperíodo de 16 horas e irradiância de $50 \mu \mathrm{mol} \mathrm{m} \mathrm{m}^{-2} \mathrm{~s}^{-1}$, até a completa germinação e expansão das folhas cotiledonares.

\subsection{Indução de calos em explantes de hipocótilo e folhas cotiledonáres de pinhão-manso}

Após 30 dias de cultivo, das plantas germinadas coletaram-se folhas cotiledonares completamente estendidas e os hipocótilos verdes, os quais foram seccionados em explantes de aproximadamente $5 \mathrm{~mm}^{2}$. Para a padronização, utilizaram-se apenas as porções medianas dos referidos explantes, mantendo a nervura central e secundaria das folhas cotiledonares.

Os explantes foram inoculados em placa de petri $(15$ x $90 \mathrm{~mm})$, contendo $25 \mathrm{~mL}$ de meio MS, acrescido de $30 \mathrm{~g} / \mathrm{L}$ de sacarose, 2,5 g/L de Phytagel@ e diferentes concentração de 2,4-diclorofenoxiacético (2,4-D) e picloram $(0,50,100,200$ e $400 \mu \mathrm{M})$, combinadas ou não com cinetina $(0$ e $50 \mu \mathrm{M})$. Adicionalmente, os explantes também foram avaliados quanto a influência do desenvolvimento de calos em condições de luz ou escuro.

Para cada tratamento foram realizadas cinco repetições, sendo cada repetição composta por uma placa de petri com cinco explantes. Para acompanhar as respostas dos tratamentos 
foram realizadas duas avaliações, aos 30 e 60 dias, observando-se: formação de calos (relação entre o número de explantes com calos em relação ao total de inoculado, em percentagem) textura dos calos formados (friável, semi-compacto e compacto), além da coloração predominante. Para melhor caracterizar os explantes nos respectivos tratamentos, também foram realizadas observações quanto a possível oxidação dos explantes em meio de cultura.

\subsection{Caracterização morfológica e anatômica de calos formados em hipocótilos e folhas cotiledonares de pinhão-manso}

Amostras de calos com 30 e 60 dias de cultivo foram fotografadas com o auxílio de estereomicroscópio (EZ4HD, Leica ${ }^{\circledR}$ ) e, posteriormente, descritas quanto as características morfológicas como cor, textura (friável, semi-compacto e compacto), intensidade de formação de calos e oxidação (baixa, moderada ou alta).

Para análise anatômica, calos com 60 dias foram coletados e fixados em Karnovsky (KARNOVSKY, 1965) por 48 horas, sob vácuo, e estocados em tampão Cacodilato $(0,05 \mathrm{~N})$ em geladeira. Posteriormente, as amostras foram desidratadas em série etílica crescente e incluídas em metacrilato (Historesina Technovit 7100, Kulzer, Alemanha). A partir do material incluído em metacrilato foram realizados cortes transversais em micrótomo rotativo (American Optical), utilizando-se navalhas de aço. Os cortes obtidos foram corados com Azul de Toluidina, pH 4,0 (O’BRIEN \& McCULLY, 1981) para caracterização anatômica estrutural, sendo as lâminas permanentes montadas em Bálsamo-do-Canadá.

Todas as lâminas foram examinadas e fotografadas em fotomicroscópio (AX70TRF, Olympus Optical, Japão) e analisadas qualitativamente quando ao tipo de calo formado e presença ou ausência de regiões meristemáticas e embriogênicas.

\subsection{Análises estatísticas}

A percentagem de explantes que formaram calo foi submetida a análise de variância (ANOVA) e as médias comparadas pelo teste Scott-Knott empregando-se o programa ASSISTAT Versão 7.7 beta (2011) da Universidade Federal de Campina Grande (SILVA e AZEVEDO, 2009). 


\section{RESULTADOS E DISCUSSÃO}

\subsection{Indução de calos em hipocótilos e folhas cotiledonáres de pinhão-manso}

O início da formação de calos em folhas cotiledonares e hipocótilos foi observado a partir de aproximadamente uma semana de cultivo, independente do ambiente de luz ou escuro, pelo o intumescimento dos explantes e o início da proliferação celular característica de calogênese.

Já aos 30 dias de cultivos, com algumas exceções, tratamentos com hipocótilos cultivados na luz e no escuro apresentaram taxas de formação de calos que foram superiores a 90\% dos explantes (Tabela 1).

Aos 60 dias de cultivo, apenas o(s) tratamento(s contendo cinetinano meio de cultura é que apresentou (aram) baixas calogênese. No restante dos tratamentos, todos os explantes responderam com praticamente $100 \%$ dos explantes formando calos. (Tabela 1).

Ainda em hipocótilos foi possível observar que aos 30 dias de cultivo, independente da condição de luz ou escuro, todos os tratamentos contendo picloram apresentaram explantes com e formação de calos acima de $96 \%$, não havendo diferenças estatísticas entre os tratamentos. Já nos tratamentos contendo 2,4-D nas concentrações de 50 e $100 \mu \mathrm{M}$, sem a adição de cinetina, apresentaram 100\% de explantes com calos apenas após 60 dias de cultivo (Tabela 1).

Quando se utilizou folhas cotiledonares como explantes maiores variações quanto as taxas de formação de calos foram observadas entre os tratamentos, especialmente nos primeiros 30 dias de avaliação (Tabela 2). Como era de se esperar, os menores valores foram verificados no tratamento controle, o qual era desprovido de reguladores de crescimento. Entretanto, quando em tratamentos com reguladores de crescimento, com ou sem a presença de cinetina e sob condições de escuro, os explantes formados por folhas cotiledonares apresentaram índices de formação de calos que variaram entre $88,2 \%$ a $100 \%$ aos 30 dias de cultivo, sendo os menores valores observados em tratamentos com 2,4-D em sua maior concentração. Já aos 60 dias de cultivo, a formação de calos alcançou 100\% dos explantes cultivados em meio de cultura no escuro, independentemente da combinação de reguladores de crescimento utilizada. E, assim como verificado aos 30 dias, os menores valores para formação de calos foram observados nos tratamentos desprovidos de reguladores de crescimento (tratamento controle) (Tabela 2). 
Tabela 1: " Percentagem de hipocótilos de pinhão-manso (Jatropha curcas L.) com formação de calos quando cultivados em meio de MS, suplementado com 2,4-D ou picloram em associação com cinetina, em condições de luz e escuro, após 30 e 60 dias

\section{HIPOCÓTILO}

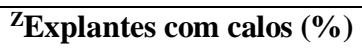

\begin{tabular}{|c|c|c|c|c|c|c|}
\hline \multirow[b]{2}{*}{ Auxinas } & \multirow[b]{2}{*}{$\begin{array}{c}\text { Concentração } \\
(\mu \mathrm{M})\end{array}$} & \multirow[b]{2}{*}{$\begin{array}{l}\text { Cinetina } \\
(50 \mu \mathrm{M})\end{array}$} & \multicolumn{2}{|c|}{30 Dias } & \multicolumn{2}{|c|}{60 Dias } \\
\hline & & & Luz & Escuro & Luz & Escuro \\
\hline Controle & $\mathbf{0}$ & - & $100 \pm 0,0 \mathrm{Aa}$ & $100 \pm 0,0 \mathrm{aA}$ & $100 \pm 0,0 \mathrm{aA}$ & $100 \pm 0,0 \mathrm{aA}$ \\
\hline \multirow{4}{*}{ 2,4-D } & 50 & - & $90,2 \pm 2,1 \mathrm{Ba}$ & $55,5 \pm 5,3 \mathrm{bB}$ & $100 \pm 0,0 \mathrm{aA}$ & $100 \pm 0,0 \mathrm{aA}$ \\
\hline & 100 & - & $80,1 \pm 9,4 \mathrm{Ca}$ & $45,4 \pm 5,2 \mathrm{cB}$ & $100 \pm 0,0 \mathrm{aA}$ & $100 \pm 0,0 \mathrm{aA}$ \\
\hline & 200 & - & $96,5 \pm 4,4 \mathrm{Aa}$ & $100 \pm 0,0 \mathrm{aA}$ & $100 \pm 0,0 \mathrm{aA}$ & $100 \pm 0,0 \mathrm{aA}$ \\
\hline & 400 & - & $100 \pm 0,0 \mathrm{Aa}$ & $92,1 \pm 4,9 \mathrm{aA}$ & $100 \pm 0,0 \mathrm{aA}$ & $100 \pm 0,0 \mathrm{aA}$ \\
\hline \multirow{4}{*}{ Picloram } & 50 & - & $100 \pm 0,0 \mathrm{Aa}$ & $100 \pm 0,0 \mathrm{aA}$ & $100 \pm 0,0 \mathrm{aA}$ & $100 \pm 0,0 \mathrm{aA}$ \\
\hline & 100 & - & $96,3 \pm 4,1 \mathrm{Ab}$ & $100 \pm 0,0 \mathrm{aA}$ & $96,5 \pm 4,1 \mathrm{aB}$ & $100 \pm 0,0 \mathrm{aA}$ \\
\hline & 200 & - & $100 \pm 0,0 \mathrm{Aa}$ & $100 \pm 0,0 \mathrm{aA}$ & $100 \pm 0,0 \mathrm{aA}$ & $100 \pm 0,0 \mathrm{aA}$ \\
\hline & 400 & - & $100 \pm 0,0 \mathrm{Aa}$ & $100 \pm 0,0 \mathrm{aA}$ & $100 \pm 0,0 \mathrm{aA}$ & $100 \pm 0,0 \mathrm{aA}$ \\
\hline Controle & $\mathbf{0}$ & + & $100 \pm 0,0 \mathrm{Aa}$ & $100 \pm 0,0 \mathrm{aA}$ & $100 \pm 0,0 \mathrm{aA}$ & $100 \pm 0,0 \mathrm{aA}$ \\
\hline \multirow{4}{*}{ 2,4-D } & 50 & + & $100 \pm 0,0 \mathrm{Aa}$ & $100 \pm 0,0 \mathrm{aA}$ & $100 \pm 0,0 \mathrm{aA}$ & $100 \pm 0,0 \mathrm{aA}$ \\
\hline & 100 & + & $92,2 \pm 2,2 \mathrm{Bb}$ & $96,3 \pm 4,2 \mathrm{aA}$ & $100 \pm 0,0 \mathrm{aA}$ & $100 \pm 0,0 \mathrm{aA}$ \\
\hline & 200 & + & $100 \pm 0,0 \mathrm{Aa}$ & $100 \pm 0,0 \mathrm{aA}$ & $100 \pm 0,0 \mathrm{aA}$ & $100 \pm 0,0 \mathrm{aA}$ \\
\hline & 400 & + & $100 \pm 0,0 \mathrm{Aa}$ & $96,1 \pm 4,4 \mathrm{aA}$ & $100 \pm 0,0 \mathrm{aA}$ & $100 \pm 0,0 \mathrm{aA}$ \\
\hline \multirow{4}{*}{ Picloram } & 50 & + & $100 \pm 0,0 \mathrm{Aa}$ & $100 \pm 0,0 \mathrm{aA}$ & $100 \pm 0,0 \mathrm{aA}$ & $100 \pm 0,0 \mathrm{aA}$ \\
\hline & 100 & + & $100 \pm 0,0 \mathrm{Aa}$ & $100 \pm 0,0 \mathrm{aA}$ & $100 \pm 0,0 \mathrm{aA}$ & $100 \pm 0,0 \mathrm{aA}$ \\
\hline & 200 & + & $100 \pm 0,0 \mathrm{Aa}$ & $100 \pm 0,0 \mathrm{aA}$ & $100 \pm 0,0 \mathrm{aA}$ & $100 \pm 0,0 \mathrm{aA}$ \\
\hline & 400 & + & $100 \pm 0,0 \mathrm{Aa}$ & $100 \pm 0,0 \mathrm{aA}$ & $100 \pm 0,0 \mathrm{aA}$ & $100 \pm 0,0 \mathrm{aA}$ \\
\hline
\end{tabular}

${ }^{\mathrm{Z}}$ Médias seguidas pela mesma letra minúscula na coluna e maiúscula na linha não diferem entre sí pelo teste de Scott-knott ao nível de 5\% de probabilidade. (-): ausência de cinetina; (+): presença de cinetina no meio de cultura.

Soomro e Memon (2007) também obtiveram sucesso na formação de calos provenientes de hipocótilos e cotilédones de pinhão-manso retirados de sementes germinadas in vitro com 4 dias de idade. Os hipocótilos apresentaram crescimento rápido de calos, visível após 7 dias de incubação. Os cotilédones levaram mais tempo, formando os calos após 15 a 20 dias de incubação. De acordo com descrição dos autores, o início dos calos ocorreu nas bordas de corte para os dois tipos de explante.

Siang et al. (2014) também investigaram a influência de diferentes auxinas na formação de calos a partir de explantes cotiledonares de pinhão-manso e, segundo os autores, a maior 
intensidade de calos foi observada nos tratamentos com Dicamba, 2,4-D e picloram respectivamente, sendo que calos obtidos em meio com Dicamba apresentaram características embriogênicas.

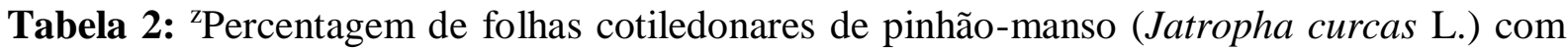
formação de calos quando cultivados em meio de MS, suplementado com 2,4-D ou picloram em associação com cinetina, em cultivos na luz e no escuro, após 30 e 60 dias

\section{FOLHAS COTILÉDONARES}

\begin{tabular}{|c|c|c|c|c|c|c|}
\hline \multirow[b]{3}{*}{ Auxinas } & \multirow[b]{3}{*}{$\begin{array}{c}\text { Concentração } \\
(\mu \mathrm{M})\end{array}$} & \multirow[b]{3}{*}{$\begin{array}{l}\text { Cinetina } \\
(50 \mu \mathrm{M})\end{array}$} & \multicolumn{4}{|c|}{ Explantes com calos (\%) } \\
\hline & & & \multicolumn{2}{|c|}{30 Dias } & \multicolumn{2}{|c|}{60 Dias } \\
\hline & & & $\mathbf{L u z}$ & Escuro & $\mathbf{L u z}$ & Escuro \\
\hline Controle & $\mathbf{0}$ & - & $32,3 \pm 8,1$ eA & $8,8 \pm 4,9 \mathrm{cB}$ & $40,2 \pm 10,9 \mathrm{dA}$ & $10,4 \pm 4,7 \mathrm{cB}$ \\
\hline \multirow{4}{*}{ 2,4-D } & 50 & - & $80,1 \pm 8,9 \mathrm{bB}$ & $100 \pm 0,0 \mathrm{aA}$ & $96,4 \pm 3,2 \mathrm{aA}$ & $100 \pm 0,0 \mathrm{aA}$ \\
\hline & 100 & - & $96,5 \pm 3,9 \mathrm{aA}$ & $100 \pm 0,0 \mathrm{aA}$ & $100 \pm 0,0 \mathrm{aA}$ & $100 \pm 0,0 \mathrm{aA}$ \\
\hline & 200 & - & $68,7 \pm 4,4 \mathrm{cB}$ & $96,5 \pm 2,2 \mathrm{aA}$ & $100 \pm 0,0 \mathrm{aA}$ & $100 \pm 0,0 \mathrm{aA}$ \\
\hline & 400 & - & $60,1 \pm 6,3 \mathrm{cB}$ & $88,2 \pm 4,2 \mathrm{bA}$ & $100 \pm 2,1 \mathrm{aA}$ & $100 \pm 0,0 \mathrm{aA}$ \\
\hline \multirow{4}{*}{ Picloram } & 50 & - & $76,2 \pm 4,7 \mathrm{bB}$ & $100 \pm 0,0 \mathrm{aA}$ & $80,4 \pm 2,3 \mathrm{bB}$ & $100 \pm 0,0 \mathrm{aA}$ \\
\hline & 100 & - & $88,1 \pm 4,2 \mathrm{aA}$ & $92,3 \pm 5,1 \mathrm{bA}$ & $92,3 \pm 2,2 \mathrm{aA}$ & $100 \pm 0,0 \mathrm{aA}$ \\
\hline & 200 & - & $100 \pm 0,0 \mathrm{aA}$ & $100 \pm 0,0 \mathrm{aA}$ & $100 \pm 0,0 \mathrm{aA}$ & $100 \pm 0,0 \mathrm{aA}$ \\
\hline & 400 & - & $96,5 \pm 4,2 \mathrm{aA}$ & $88,2 \pm 8,2 \mathrm{bB}$ & $100 \pm 0,0 \mathrm{aA}$ & $100 \pm 0,0 \mathrm{aA}$ \\
\hline Controle & $\mathbf{0}$ & + & $12,3 \pm 9,8 \mathrm{fB}$ & $8,8 \pm 5,1 \mathrm{cB}$ & $80,2 \pm 6,3 \mathrm{bA}$ & $80,2 \pm 4,8 \mathrm{bA}$ \\
\hline \multirow{4}{*}{ 2,4-D } & 50 & + & $64,7 \pm 4,1 \mathrm{cB}$ & $100 \pm 0,0 \mathrm{aA}$ & $68,1 \pm 4,8 \mathrm{cB}$ & $100 \pm 0,0 \mathrm{aA}$ \\
\hline & 100 & + & $80,2 \pm 4,9 \mathrm{bB}$ & $100 \pm 0,0 \mathrm{aA}$ & $100 \pm 0,0 \mathrm{aA}$ & $100 \pm 0,0 \mathrm{aA}$ \\
\hline & 200 & + & $72,1 \pm 4,9 \mathrm{bB}$ & $100 \pm 0,0 \mathrm{aA}$ & $72,1 \pm 4,8 \mathrm{cB}$ & $100 \pm 0,0 \mathrm{aA}$ \\
\hline & 400 & + & $48,3 \pm 8,9 \mathrm{~dB}$ & $88,2 \pm 4,3 \mathrm{bA}$ & $100 \pm 0,0 \mathrm{aA}$ & $100 \pm 0,0 \mathrm{aA}$ \\
\hline \multirow{4}{*}{ Picloram } & 50 & + & $92,1 \pm 5,2 \mathrm{aA}$ & $100 \pm 0,0 \mathrm{aA}$ & $100 \pm 0,0 \mathrm{aA}$ & $100 \pm 0,0 \mathrm{aA}$ \\
\hline & 100 & + & $100 \pm 0,0 \mathrm{aA}$ & $100 \pm 0,0 \mathrm{aA}$ & $100 \pm 0,0 \mathrm{aA}$ & $100 \pm 0,0 \mathrm{aA}$ \\
\hline & 200 & + & $92,3 \pm 5,1 \mathrm{aA}$ & $100 \pm 0,0 \mathrm{aA}$ & $100 \pm 0,0 \mathrm{aA}$ & $100 \pm 0,0 \mathrm{aA}$ \\
\hline & 400 & + & $100 \pm 0,0 \mathrm{aA}$ & $100 \pm 0,0 \mathrm{aA}$ & $100 \pm 0,0 \mathrm{aA}$ & $100 \pm 0,0 \mathrm{aA}$ \\
\hline
\end{tabular}

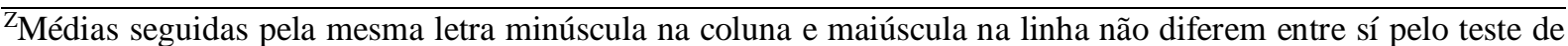
Scott-knott ao nível de 5\% de probabilidade. (-): ausência de cinetina; (+): presença de cinetina no meio de cultura.

Já Nhut et al. (2013) relataram grande proliferação de calos em explantes foliares cultivados com 2,4-D em combinação com cinetina. Segundo os autores a combinação de $1 \mathrm{mg}$ de cinetina e 2,4-D promoveram a maior formação de calos, embora as combinações de $1 \mathrm{mg}$ 
de cinetina com 0,5 e 0,1 mg de 2,4-D e até mesmo sem a presença da auxina promoveram as maiores percentagens de calos embriogênicos.

Solís-Ramos et al. (2013) observaram que no cultivo de folhas e hipocótilos de pinhãomanso com 2,4-D a cinética de crescimento dos calos se mostrou continua com o tempo de cultivo, apresentado uma variação da formação dos calos com incremento de massa fresca e seca, bem como na variação morfológica que foi classificada como friável a compacto. Estes resultados corroboram com os observados nesse trabalho, principalmente quando os explantes utilizados foram de folhas cotiledonares cultivadas em meio contendo 2,4-D como auxina.

Já para Attaya et al. (2012), o pinhão-manso responde positivamente a altas concentrações de auxina e citocinina e, em termos de número de calos e atividade dos reguladores de crescimento, explantes como epicótilo, hipocótilo e embriões zigóticos são os materiais mais adequados como explantes para a indução de calos.

\subsection{Caracterização morfológica e anatômica de calos formados em hipocótilos e folhas cotiledonares de pinhão-manso}

A análise morfoanatômica de folhas cotiledonares e de hipocótilos cultivados na luz e no escuro, sem regulador de crescimento (tratamento controle) estão apresentados na Figura 1. Mesmo sem reguladores de crescimento no meio de cultura, quando cultivados na luz por 30 dias, os hipocótilos apresentaram início de formação calos friáveis, de coloração esbranquiçada (Figura 1B). Porém, aos 60 dias houve um aumento na intensidade dos calos formados, passando a ser considerada moderada, com a oxidação permanecendo baixa, mas morfologicamente não apresentaram aspecto embriogênico (Figura 1 B e F). Anatomicamente, esses calos apresentaram células com parede celular fina e com muitos espaços entre as células, característica típica de calos friáveis (Figura 1J).

As folhas cotiledonares cultivadas na luz apresentaram baixa intensidade de calejamento, os quais se formaram nas extreminades dos explantes e na região da nervura (Figura 1 A e E). Esses calos apresentaram um aspecto mais compacto e anatomicamente foi observado uma proliferação de células mais justapostas, com paredes mais delgadas e tipicamente parenquimáticas (Figura $1 \mathrm{I}$ ).

No escuro, além dos hipocótilos (Figura 1 D), também ocorreu a formação de calos visíveis em explantes de folhas cotiledonares cultivados por 30 dias (Figura 1C), principalmente nas extremidades e nas regiões das nervuras (baixa intersidade de calejamento). Porém, aos 60 dias os calos praticamente desapareceram em função da aparente senescência do explante que 
apresentava alta oxidação (Figura 1G). Os aspectos anatômicos desses calos sugerem uma formação de calos não embriogênicos, composto por células mais compactas e de citoplasma mais denso (Figura 1L). Já em hipocótilos, foi visualizado apenas células parenquimáticas na composição dos calos as células dos calos (Figura $1 \mathrm{M}$ ).

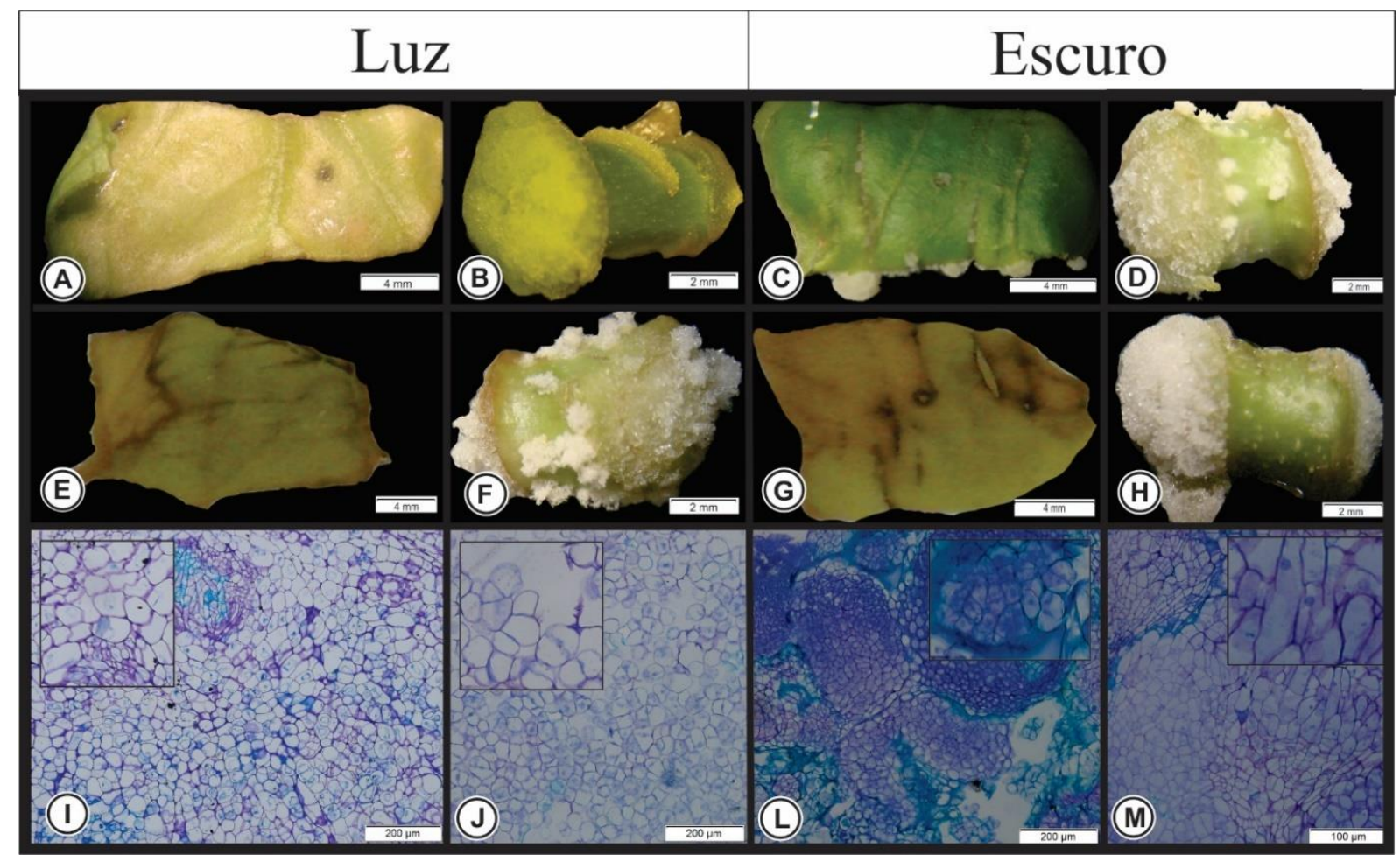

Figura 1: Análise morfológica e anatômica de calos de pinhão-manso (Jatropha curcas L.) obtidos a partir de folhas cotiledonares e hipocótilos cultivados na luz ou no escuro em meio de MS, sem a presença de reguladores de crescimento (tratamento controle). A - D: explantes cultivados por 30 dias. E-H: explantes cultivados por 60 dias. I e L: Anatomia de calos de folhas cotiledonares. J e M: Anatomia de calos de hipocótilos.

De acordo com Narayanaswamy (1977), o calo corresponde a uma massa de células desorganizadas e parcialmente indiferenciadas que variam quanto ao tipo, tamanho, conteúdo celular e espessura da parede. Relatos de formação de calos em explantes cultivados em meio sem regulador de crescimento foram feitos por Santos et al. (2013) e Reis et al. (2007) em diferentes explantes de Castanheira-do-brasil e Ingá. E segundo os autores essa formação de calos pode correr em respostas as injúrias físicas provocadas nos explantes durante a inoculação e ao conteúdo endógeno de auxinas e citocinina de cada explante. Essa afirmação, de certa forma, explicaria a formação dos calos principalmente nas extremidades lesadas pelo bisturi.

Nos tratamentos contendo somente $50 \mu \mathrm{M}$ de cinetina, folhas cotiledonares praticamente não formaram calos aos 30 dias, tanto quando cultivadas na luz ou no escuro, enquanto os hipocótilos apresentaram calos semi-compactos de coloração verde-amarelada 
nestas condições (Figura 2 A- e B). Já aos 60 dias de cultivo, explantes cultivados na luz apresentaram aumento na quantidade de calos formados em ambos os propágulos, os quais caracterizavam-se por apresentar textura semi-compacta e friável, de coloração esbranquiçada (Figura 2 E e F). Já no escuro, os calos nas folhas cotiledonares foram de tipos compactos a friáveis, a maioria deles em formas globulares, variando de uma coloração bege a esbranquiçada (Figura 2 C e G), enquanto nos hipocótilos houve formação de calos semi-compactos e friáveis esbranquiçados (Figura $2 \mathrm{D}$ e H).

A análise anatômica desse tratamento não revelou indícios de tratar-se de uma formação embriogênica, mesmo em folhas cultivadas no escuro que, morfologicamente apresentaram estruturas globulares (Figura 2 G). Nesse caso, a formação pareceu ser de células pouco agregadas, de um calo friável ou semi-compacto, com acúmulo de algum tipo de conteúdo (Figura 2 L). Já as células constituintes dos calos formados em hipocótilos no escuro aparecem mais justapostas, caracterizando um calo mais compacto com uma pequena região de células com citoplasma mais denso e núcleo evidente, indicando, em princípio, tratar-se de uma região meristemática (Figura $2 \mathrm{M}$ ). Os calos de explantes cultivados na luz também não apresentaram formações embriogênicas. Nas folhas cotiledonares, grandes espaços intercelulares foram observados, evidenciado a textura friável do calo (Firgura 2 I), enquanto nos hipocótilos apenas se observou uma divisão celular desordenada (Figura $2 \mathrm{~J}$ ).

Balasubramanya et al. (2012) também observaram a formação de calos verdes, brancos e marrons, com características nodulares em folhas de Plectranthus barbatus cultivas em meio contendo apenas cinetina. Nhut et al. (2013) relataram a formação de calos em explantes foliares de pinhão-manso cultivados em meio contendo apenas cinetina. Entretanto, segundo esses autores, o meio de cultura contendo apenas essa citocinina foi interessante somente quando os calos oriundos de cultura anterior contendo cinetina e 2,4-D foram transferidos para o meio com $1 \mathrm{mg} / \mathrm{L}$ de cinetina, onde ocorreu a indução de mais de 70\% de calos embriogênicos. Jha et al. (2007) também obtiveram calos friáveis amarelados, nodulares creme e compactos castanho-esverdeados e marrom em folhas de pinhão-manso cultivadas em meio contendo apenas cinetina. 


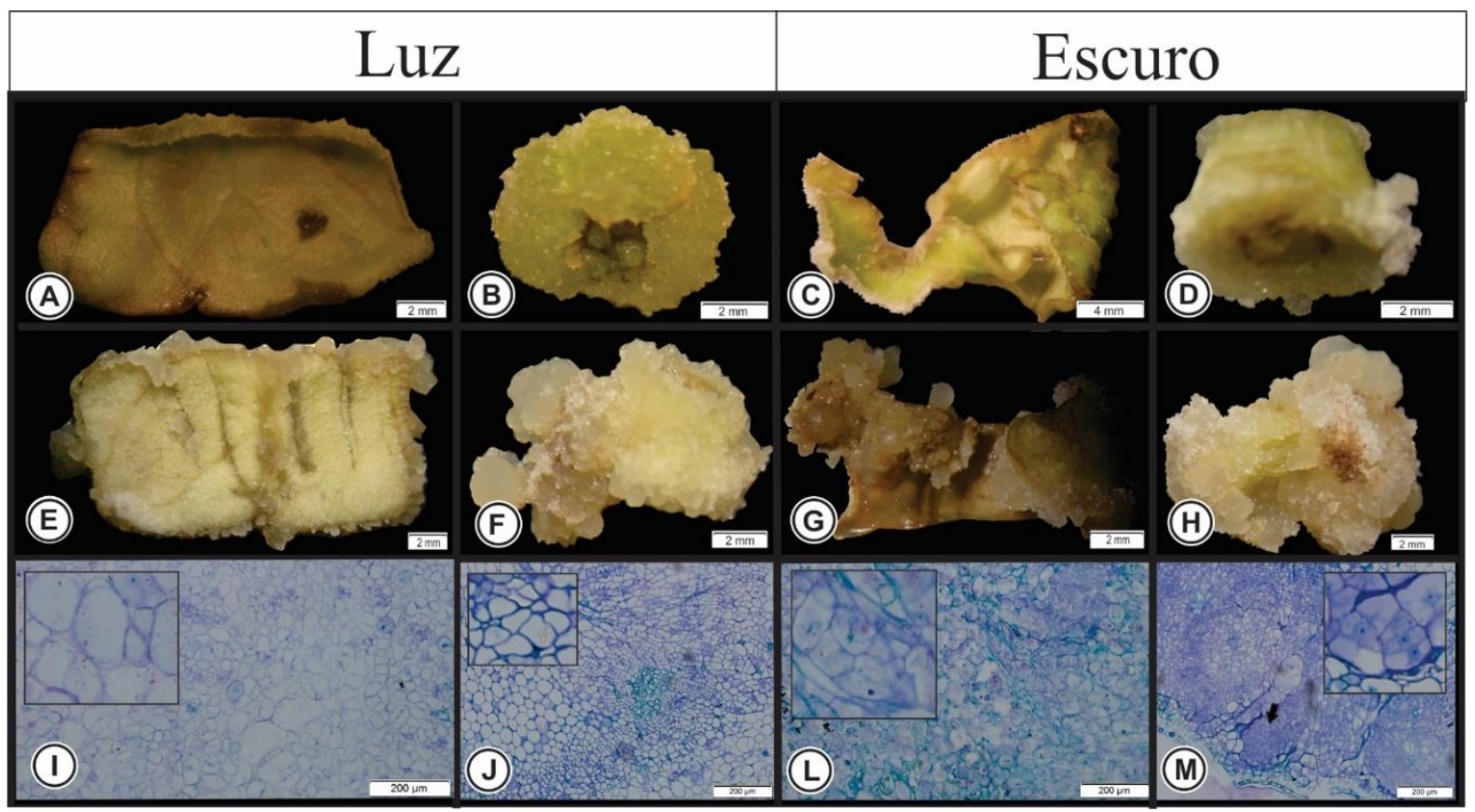

Figura 2: Análise morfológica e anatômica de calos de pinhão-manso (Jatropha curcas L.) obtidos a partir de folhas cotiledonares e hipocótilos cultivados na luz ou no escuro, em meio de MS suplementado com $50 \mu \mathrm{M}$ de cinetina. A - D: explantes cultivados por 30 dias. E-H: explantes cultivados por 60 dias. I e L: Anatomia de calos de folhas cotiledonares. J e M: Anatomia de calos de hipocótilos.

Nos tratamentos com $50 \mu \mathrm{M}$ de 2,4-D verificou-se a indução de calos em ambos os tipos de explantes (Figura 3). De maneira geral, tanto em condições de luz como no escuro, ocorreu à formação de calos semi-compactos a friáveis de coloração verde a verde-esbranquiçada, em ambos os explantes. Já aos 60 dias de cultivo, observou-se a perda da coloração esverdeada, predominando a coloração esbranquiçada para os calos formados. A análise anatômica revelou apenas proliferações celulares sem organização aparente. Apenas nos calos de folhas cultivadas na luz foram observadas pequenas regiões com células meristemáticas, mas sem uma típica organização embriogênica (Figura 3 I). 


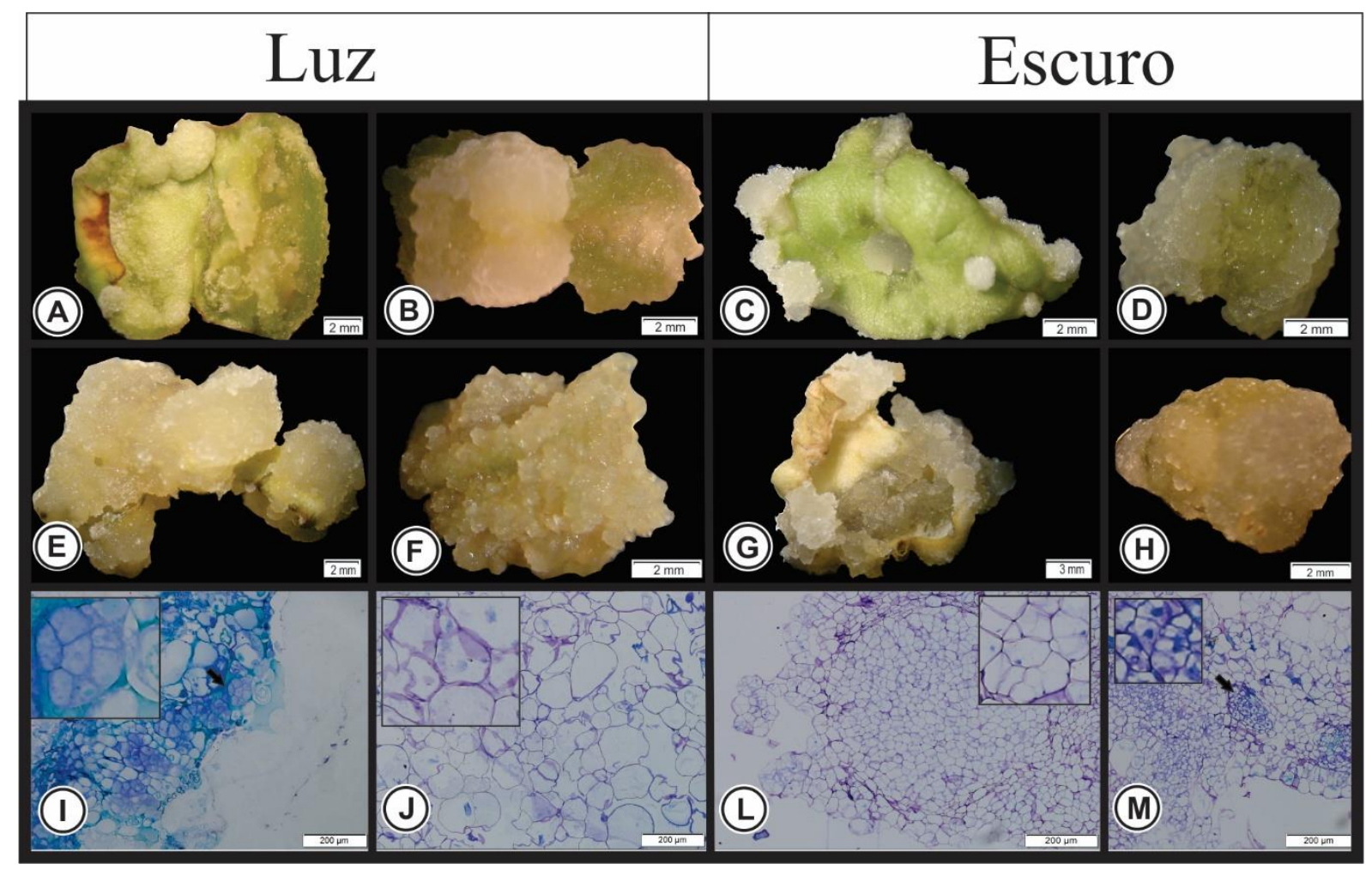

Figura 3: Análise morfológica e anatômica de calos de pinhão-manso (Jatropha curcas L.) obtidos a partir de folhas cotiledonares e hipocótilos cultivados na luz ou no escuro, em meio de MS suplementado com $50 \mu \mathrm{M}$ de 2,4-D. A - D: explantes cultivados por 30 dias. E-H: explantes cultivados por 60 dias. I e L: Anatomia de calos de folhas cotiledonares. J e M: Anatomia de calos de hipocótilos.

Com $50 \mu \mathrm{M}$ de picloram, explantes cultivados por 30 dias formaram calos semicompactos a friáveis, com aspectos da coloração que variaram de transparentes a verdeesbranquiçados, bastante semelhantes no aspecto morfológico quando cultivados na luz ou escuro (Figura 4). Aos 60 dias de cultivo, o início de clorose e oxidação dos explantes foram evidentes. Nestas condições, os calos já aparentavam aspecto semi-compacto e compacto de coloração mais amarelada, a qual variou de bege a creme. Na análise anatômica não foi observado regiões características com células de aspecto meristemático, invocando que esse tratamento apenas induziu calos não embriogênicos. 


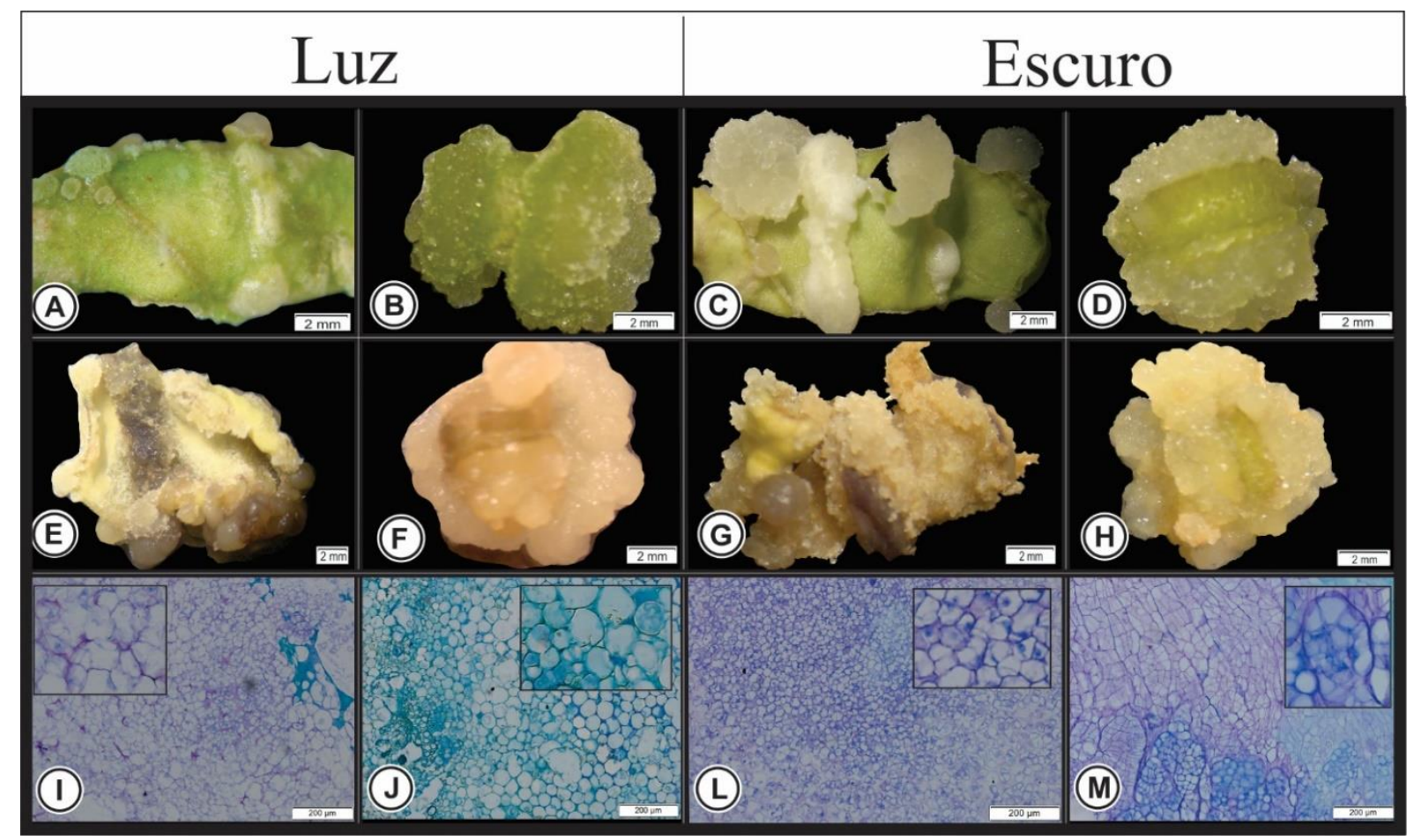

Figura 4: Análise morfológica e anatômica de calos de pinhão-manso (Jatropha curcas L.) obtidos a partir de folhas cotiledonares e hipocótilos cultivados na luz ou no escuro em meio de MS, suplementado com $50 \mu \mathrm{M}$ de picloram. A - D: explantes cultivados por 30 dias. E-H: explantes cultivados por 60 dias. I e L: Anatomia de calos de folhas cotiledonares. J e M: Anatomia de calos de hipocótilos.

Nos tratamentos onde se combinou 2,4-D e cinetina nas concentrações de $50 \mu \mathrm{M}$ se observou que explantes originários de folhas cotiledonares cultivados por 30 dias na luz apresentavam calos compactos de coloração esverdeado, diferentemente do hipocótilo que se encontrava com calos amarelados friáveis (Figura 5 A e B). Neste período, ambos os explantes cultivados no escuro permaceram verdes com calos compactos, mas principalmente com formações de calos transparentes semi-compactos (Figura $5 \mathrm{C}$ e D). Aos 60 dias, as folhas cotiledonares e os hipocótilos, cultivados respectivamente na luz e escuro, se apresentam mais cloróticos, com calos compactos de cor predominantemente creme (Figura 5 E e H). Já quando hipocótilos foram cultivados na luz e folhas cotiledonares no escuro, verificaram-se calos compactos a semi-compactos de coloração variando de esbranquiçada a bege (Figura 5 E e G). A análise anatômica desses tratamentos evidenciou o início e formação de células meristemáticas características, especialmente nos calos originários de hipocótilos cultivados por 60 dias em condições de luz (Figura 5 J). Já nos demais tratamentos, calos semi-compactos promoveram apenas a proliferação celular, aparentemente frouxa e com grandes espeços intracelulas. 


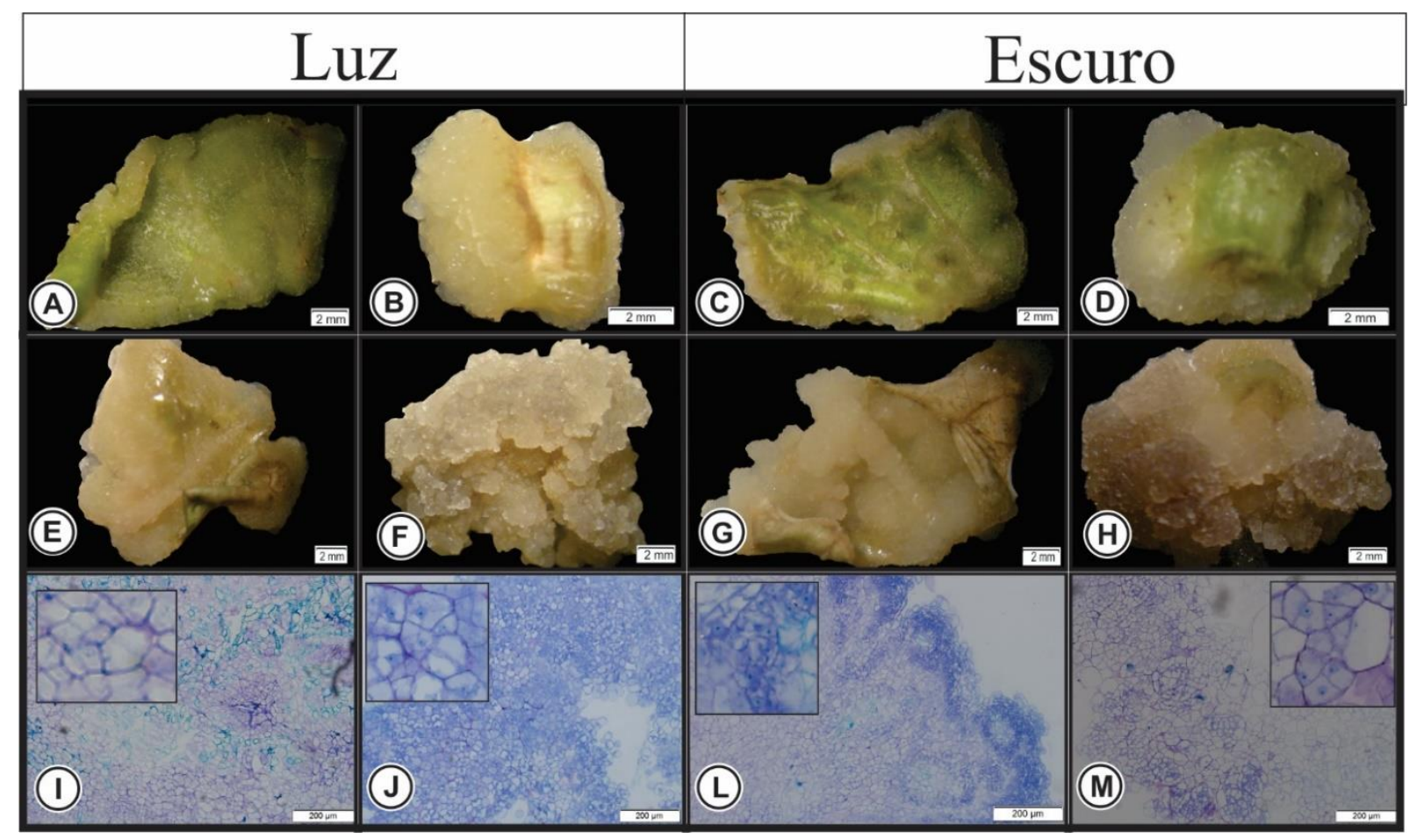

Figura 5: Análise morfológica e anatômica de calos de pinhão-manso (Jatropha curcas L.) obtidos a partir de folhas cotiledonares e hipocótilos cultivados na luz ou no escuro em meio de MS, suplementado com $50 \mu \mathrm{M}$ de 2,4-D e $50 \mu \mathrm{M}$ de cinetina. A - D: explantes cultivados por 30 dias. E-H: explantes cultivados por 60 dias. I e L: Anatomia de calos de folhas cotiledonares. J e M: Anatomia de calos de hipocótilos.

Nos tratamentos utilizando-se picloram e cinetina na concentração de $50 \mu \mathrm{M}$ verificouse a formação de calos friáveis a semi-compactos, de coloração esbranquiçada a verde amarelado, na grande maioria dos explantes cultivados por 30 dias, independentemente deles terem sido cultivados na luz ou escuro (Figura 6). Já com 60 dias de cultivo, verificou-se um aumento da massa dos calos em todos os explantes, agora de coloração um pouco mais amarelada. Nesses tratamentos foram observados especialmente a formação de calos com aspecto mais esponjoso, aparentemente sem características morfogênicas ou embriogênicas. Anatomicamente, os calos desses tratamentos não formaram regiões características com células meristemáticas, com exceção de algumas regiões dos hipocótilos cultivados no escuro e por 60 dias, tendo sido observado, na grande maioria dos materiais analisados, apenas proliferação celular, de células aparentando pouco conteúdo interno, paredes celulares finas, de várias formas, que variaram de arredondadas, mais achatadas até alongadas. 


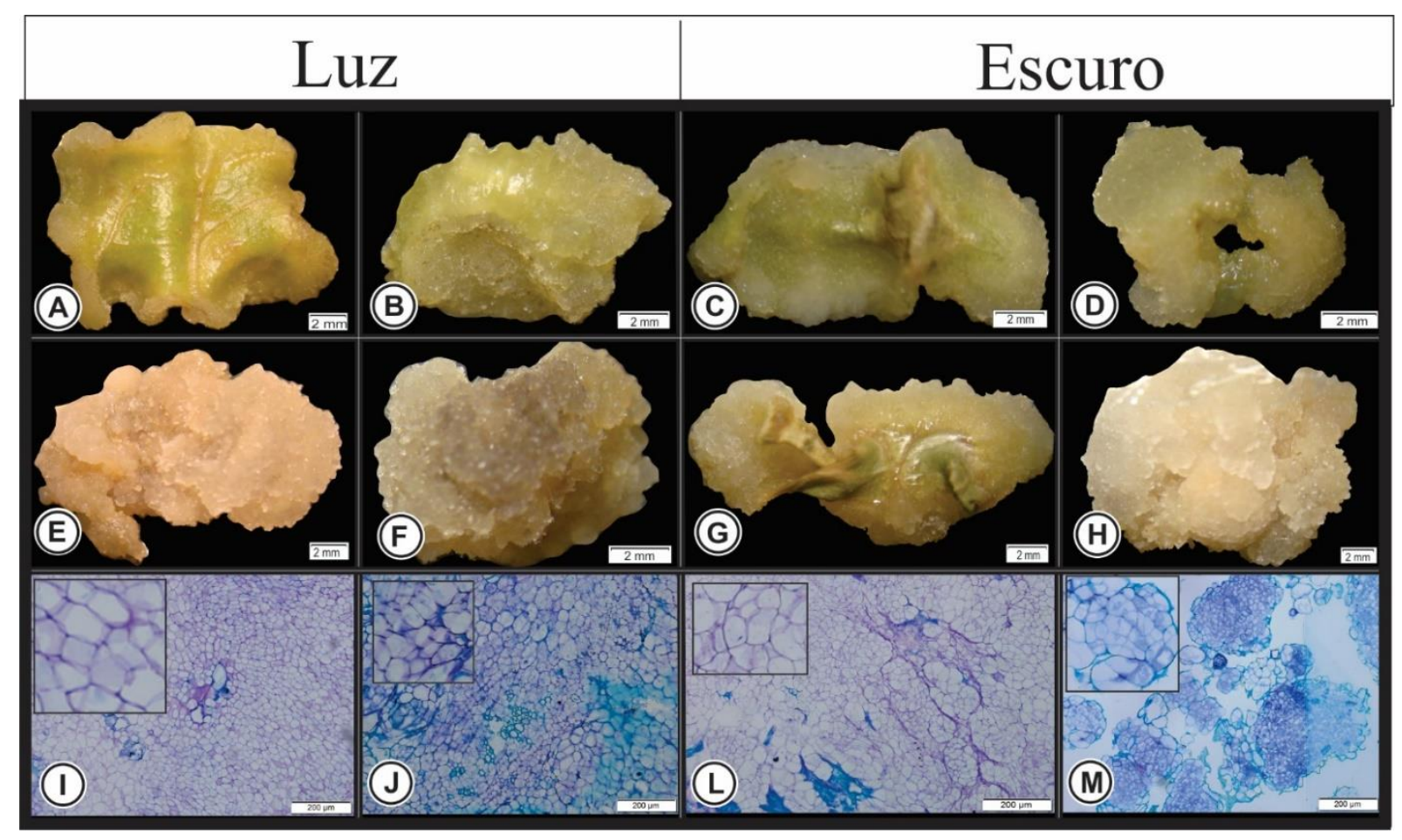

Figura 6: Análise morfológica e anatômica de calos de pinhão-manso (Jatropha curcas L.) obtidos a partir de folhas cotiledonares e hipocótilos cultivados na luz ou no escuro em meio de MS, suplementado com $50 \mu \mathrm{M}$ de picloram e $50 \mu \mathrm{M}$ de cinetina. A - D: explantes cultivados por 30 dias. E-H: explantes cultivados por 60dias. I e L: Anatomia de calos de folhas cotiledonares. J e M: Anatomia de calos de hipocótilos.

Em meio de cultura com $100 \mu \mathrm{M}$ de 2,4-D os explantes se apresentaram sem ou com baixa oxidação, com a formação de calos que variaram de compacto a friável, incluindo semicompacto, e variando em colaração do esbranquiçado ao verde e translúcido, nos primeiros 30 dias de cultivo (Figura 7 A-D). Já aos 60 dias foi observado início de clorose nos explantes formados folhas cotiledonares, com a formação de calos compactos, semi-compractos e friáveis de coloração especialmente esbranquiçada neste tipo de explante (Figura 7 E e G). Nos hipocótilos houve a formação de calos compactos, com regiões globulares de coloração bege, especialmente sob condições de luz, uma vez que no escuro os calos apresentaram coloração mais clara e homogênea (Figura $7 \mathrm{~F}$ e H). As características anatômicas dos calos desse tratamento foram semelhantes àquelas do tratamento anterior, embora os calos de hipocótilos na luz, aos 60 dias, tenham apresentado características importantes quanto ao aspecto morfogênico que, anatomicamente, não foram detectados com os cortes efetuados. 


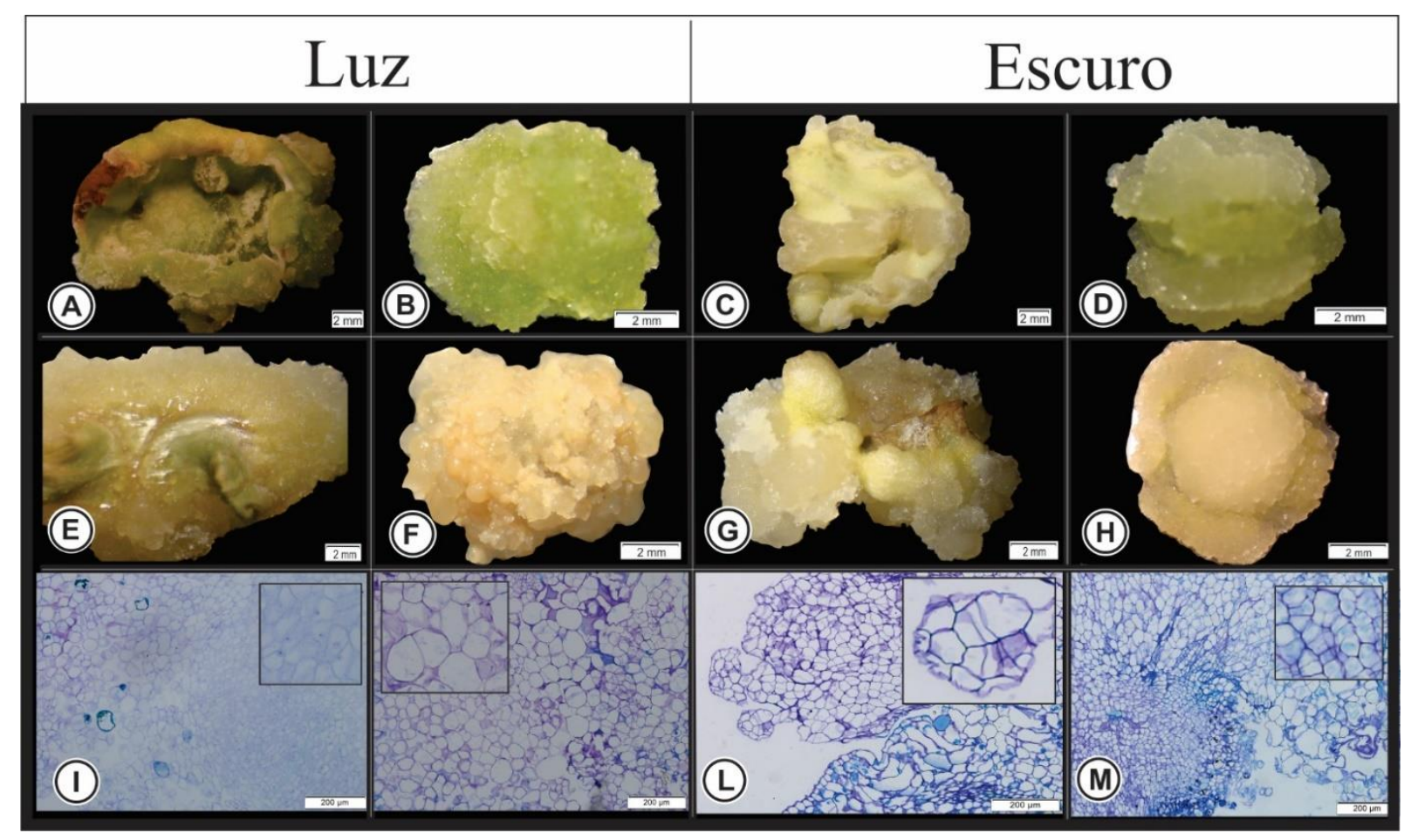

Figura 7: Análise morfológica e anatômica de calos de pinhão-manso (Jatropha curcas L.) obtidos a partir de folhas cotiledonares e hipocótilos cultivados na luz ou no escuro em meio de MS, suplementado com $100 \mu \mathrm{M}$ de 2,4-D. A - D: explantes cultivados por 30 dias. E-H: explantes cultivados por 60 dias. I e L: Anatomia de calos de folhas cotiledonares. J e M: Anatomia de calos de hipocótilos.

A utilização de picloram na concentração de $100 \mu \mathrm{M}$ induziu a formação de calos aparentemente friáveis, de coloração verde clara em folhas cotiledonares, e calos semicompactos a friáveis, de coloração verde-amarelada a esbranquiçados, no hipocótilo cultivados por 30 dias na luz (Figura 8 A-B). Aos 60 dias, esses calos apresentavam uma coloração bege ou creme e um aspecto compacto a semi-compacto, em ambos os explantes testados (Figura 8 E e F). No escuro, além de calos semi-compactos e friáveis esbranquiçados e translúcidos observados em folhas com 30 dias de cultivo, no hipocótilo foi possível obervar também a formação de calos mais compactos e granulares, de coloração bege, especilamente aos 60 dias (Figura 8 D e H). Anatomicamente, verificou-se formação menos compacta e não meristemática em calos cultivados na luz, principalmente em hipocótilos. Já nos explantes cultivados nos escuro, observou-se a formação de algumas regiões com células de citoplasma mais denso. Essa característica meristemática foi especialmente bem visível nas celulas mais periféricas dos calos dos hipocótilos. 


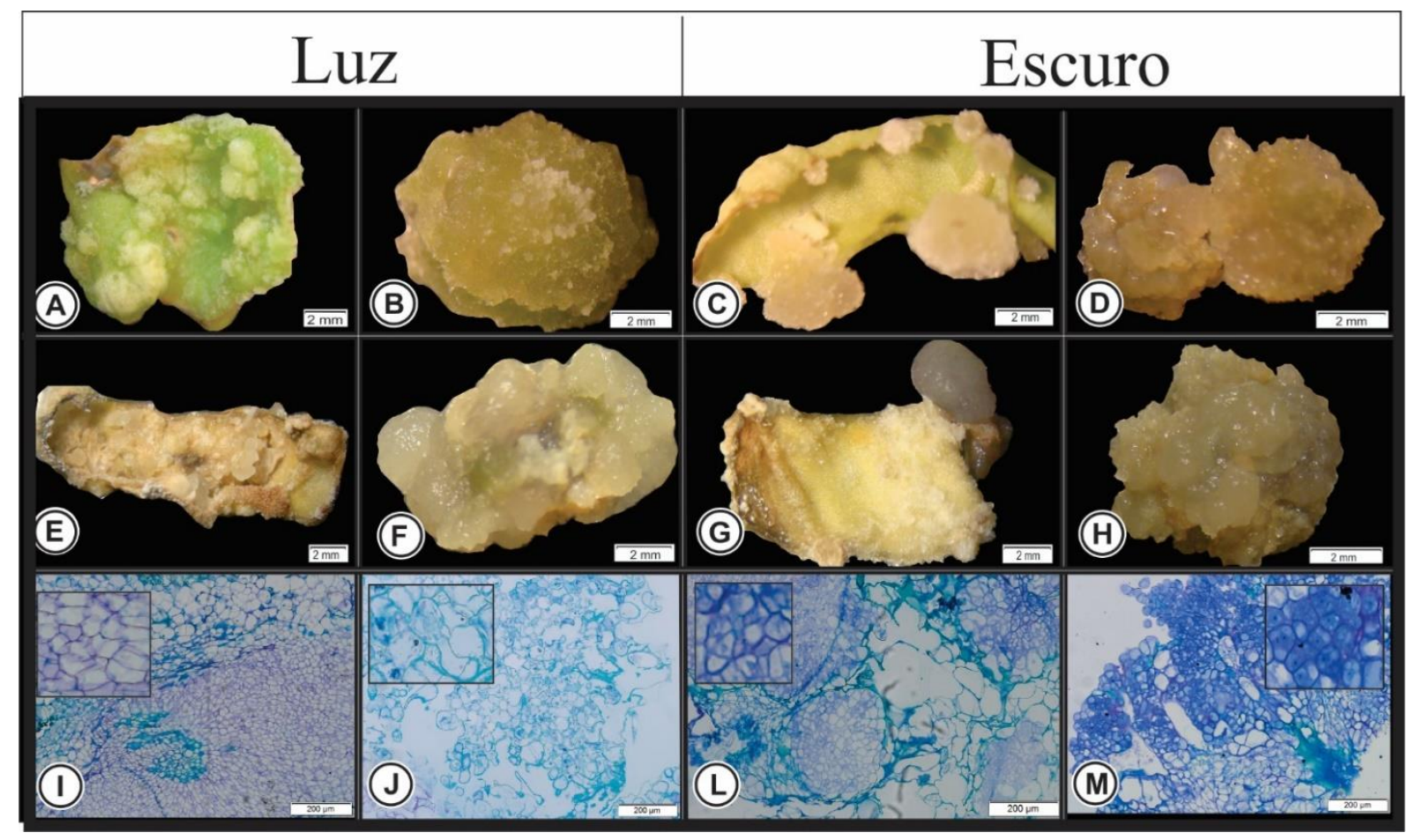

Figura 8: Análise morfológica e anatômica de calos de pinhão-manso (Jatropha curcas L.) obtidos a partir de folhas cotiledonares e hipocótilos cultivados na luz ou no escuro em meio de MS, suplementado com $100 \mu \mathrm{M}$ de picloram. A - D: explantes cultivados por 30 dias. E-H: explantes cultivados por 60 dias. I e L: Anatomia de calos de folhas cotiledonares. J e M: Anatomia de calos de hipocótilos.

Ao se fazer a combinação de $100 \mu \mathrm{M}$ de 2,4-D com $50 \mu \mathrm{M}$ de cinetina, obtiveram-se calos compactos e semi-compactos, de coloração esbranquiçada a esverdeada, em ambos os explantes aos 30 dias de cultivo na luz, que foram bastante semelhantes aqueles formados no escuro (Figura 9 A-D). Já com 60 dias, a maior formação de calos na luz foi de compactos e semi-compactos de coloração especialmente bege, sendo que nos hipocótilos, houve grande formação de estruturas globulares, de diversos tamanhos, as quais também foram observados em hipocótilos cultivados por 60 dias no escuro, mas levemente mais claras e de menor tamanho (Figura $9 \mathrm{E}-\mathrm{H}$ ). $\mathrm{Na}$ análise anatômica de calos obtidos de folhas cotiledonares não foram observadas formações embriogênicos (Figura 9 I e L). Entretanto, células meristemáticas foram observadas em regiões dos calos de hipocótilos aos 60 dias, tanto quando cultivados na luz como no escuro (Figura $9 \mathrm{~J}$ e $\mathrm{M}$ ). 


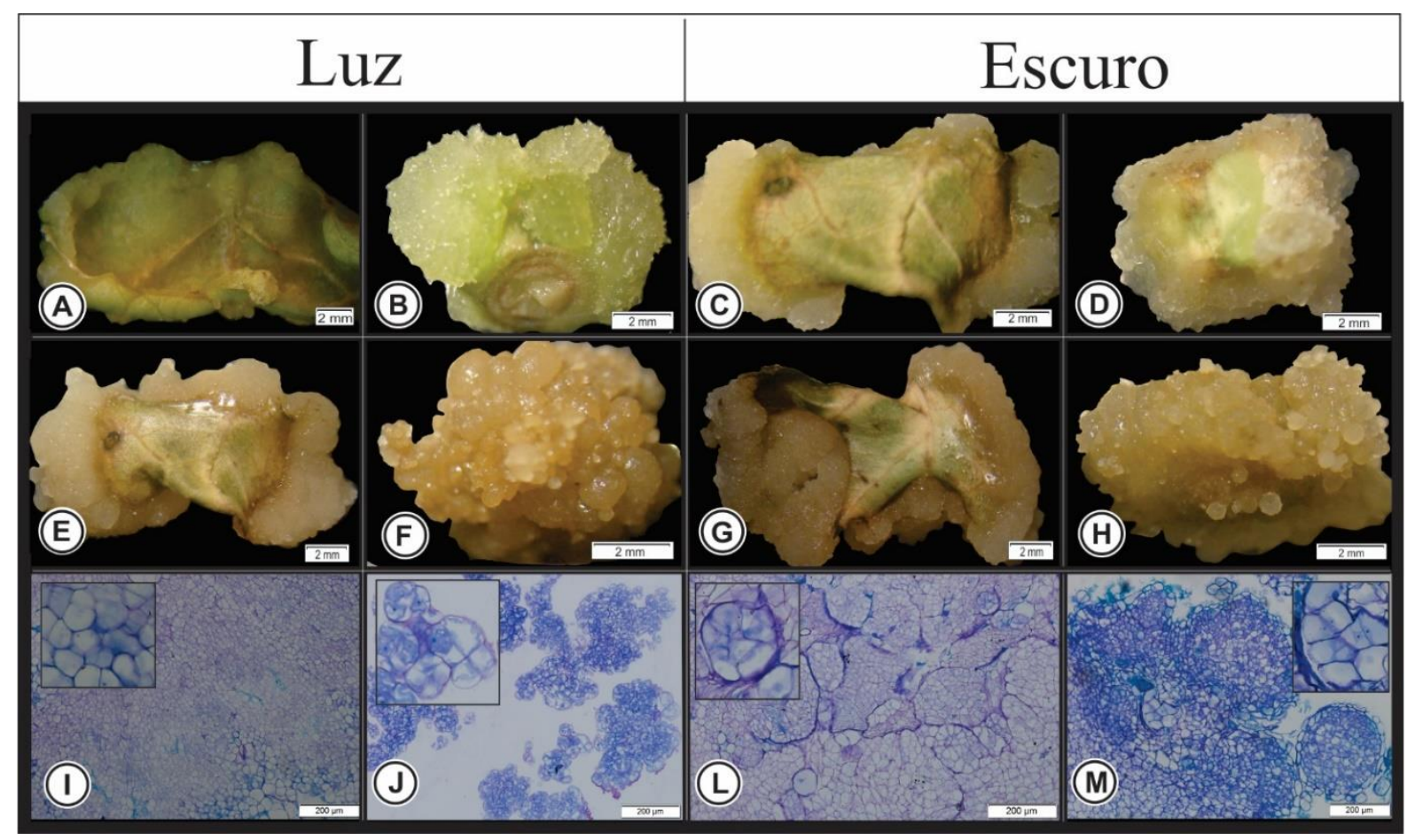

Figura 9: Análise morfológica e anatômica de calos de pinhão-manso (Jatropha curcas L.) obtidos a partir de folhas cotiledonares e hipocótilos cultivados na luz ou no escuro em meio de MS, suplementado com $100 \mu \mathrm{M}$ de 2,4-D e $50 \mu \mathrm{M}$ de cinetina. A - D: explantes cultivados por 30 dias. E-H: explantes cultivados por 60 dias. I e L: Anatomia de calos de folhas cotiledonares. J e M: Anatomia de calos de hipocótilos.

A combinação de $100 \mu \mathrm{M}$ de picloram com $50 \mu \mathrm{M}$ de cinetina proporcionou a formação de calos com aspecto semi-compactos e friáveis de coloração esbranquiçada, em praticamente todos os tratamentos, com exceção dos hipocótilos cultivados no escuro por 60 dias (Figura 10). Neste último, os calos foram de aparência semi-compacta, com estruturas multigranulares bem características (Figura 10 H). A análise anatômica confirmou características não embriogênicas para a grande maioria dos calos (Figura $10 \mathrm{I}-\mathrm{M})$. 


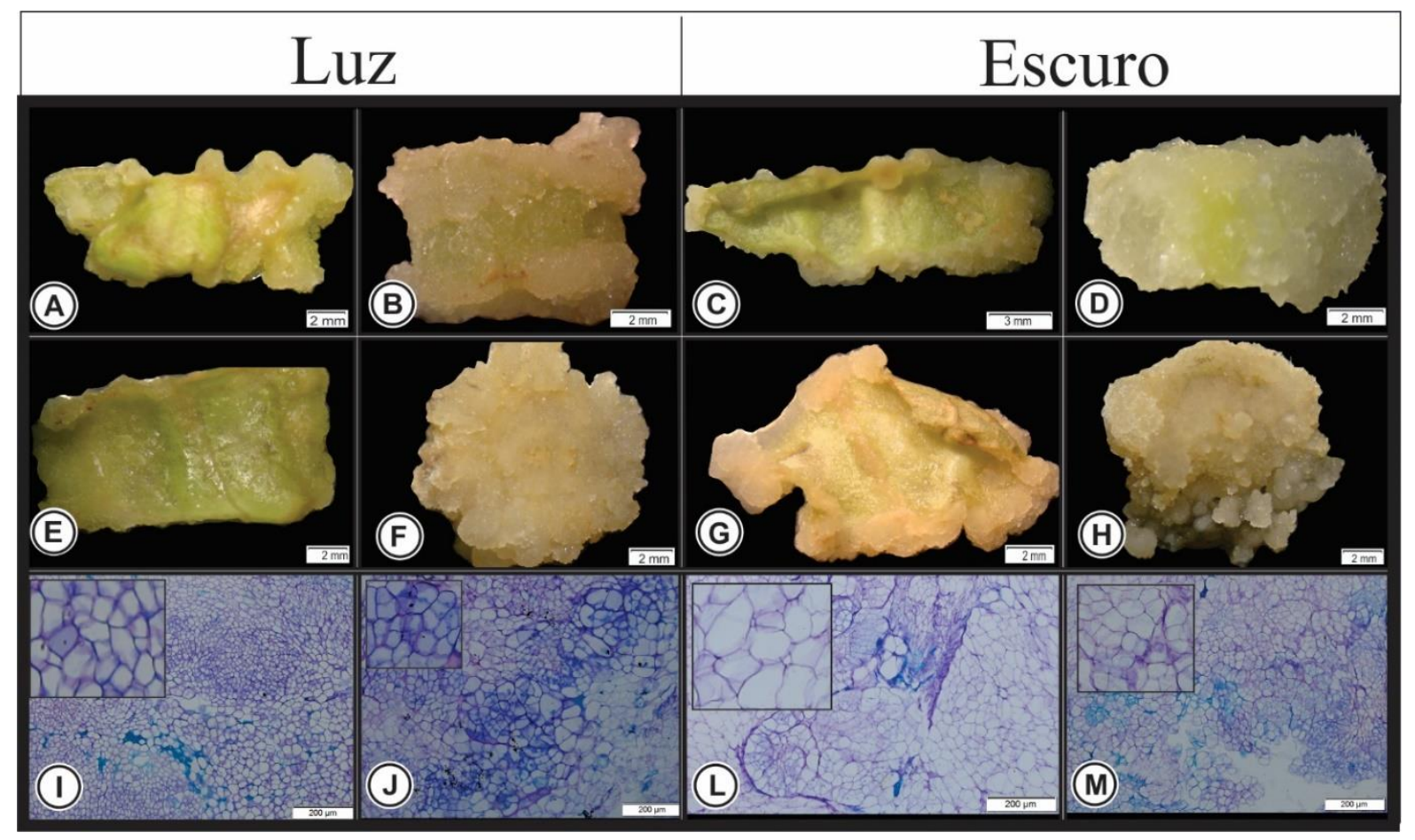

Figura 10: Análise morfológica e anatômica de calos de pinhão-manso (Jatropha curcas L.) obtidos a partir de folhas cotiledonares e hipocótilos cultivados na luz ou no escuro em meio de MS, suplementado com $100 \mu \mathrm{M}$ de Picloram e $50 \mu \mathrm{M}$ de cinetina. A - D: explantes cultivados por 30 dias. E-H: explantes cultivados por 60 dias. I e L: Anatomia de calos de folhas cotiledonares. J e M: Anatomia de calos de hipocótilos.

Nos tratamentos com apenas $200 \mu \mathrm{M}$ de 2,4 D calos semi-compactos e friáveis de coloração transparente, esverdeada e esbranquiçada foram observados de maneira geral na luz e escuro, independentemente do explante utilizado (Figura 11). Já no escuro aos 60 dias, verificou-se a formação de calos compactos e semi-compactos de cor bege para as folhas cotiledonares do escuro e esverdeados nos hipocótilos cultivados na luz, nos quais foi possível observar regiões com formações meristemáticas com alguma organização e possíveis formações embriogênicas características do início da formação de embriões somáticos (Figura $11 \mathrm{~J})$. 


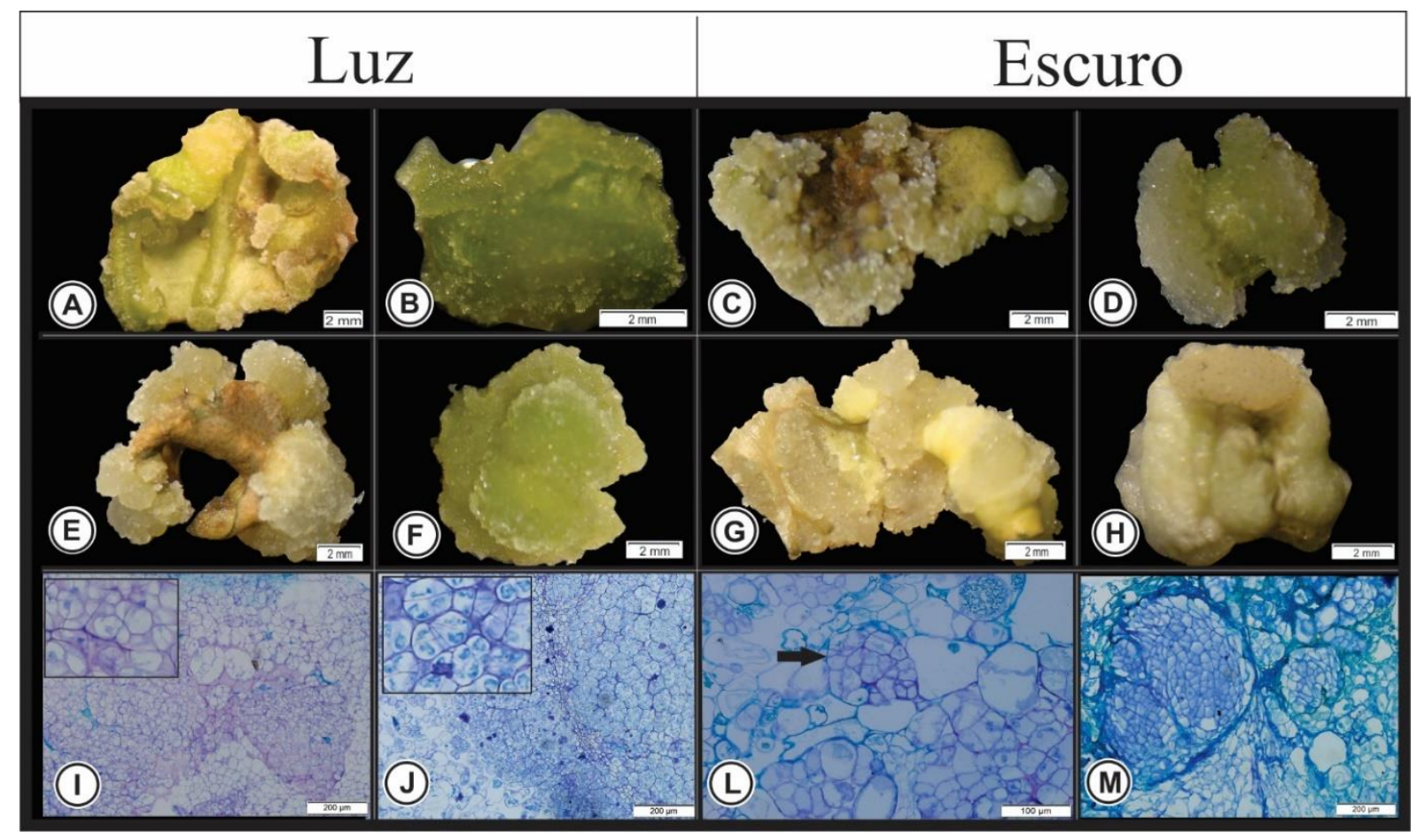

Figura 11: Análise morfológica e anatômica de calos de pinhão-manso (Jatropha curcas L.) obtidos a partir de folhas cotiledonares e hipocótilos cultivados na luz ou no escuro em meio de MS, suplementado com $200 \mu \mathrm{M}$ de 2,4-D. A - D: explantes cultivados por 30 dias. E-H: explantes cultivados por 60 dias. I e L: Anatomia de calos de folhas cotiledonares. J e M: Anatomia de calos de hipocótilos.

Com $200 \mu \mathrm{M}$ de picloram apenas os explantes com 60 dias de cultivo é que apresentaram calos de coloração amarelada e creme, inclusive com formações multigranulares, características de formações embriogênicas (Figura 12). De fato, a possibilidade de formação de porções embriogênicas foi evidenciada em calos originados de hipocótilos cultivados no claro e, especialmente, no escuro (Figura $12 \mathrm{M}$ ). A presença de células quadradas e em fileira, lado a lado, com aparente organização, especialmente nos calos dos hipocótilos, reforçam a ideia de tratar-se de possíveis regiões embriogênicas em estádios iniciais de desenvolvimento. 


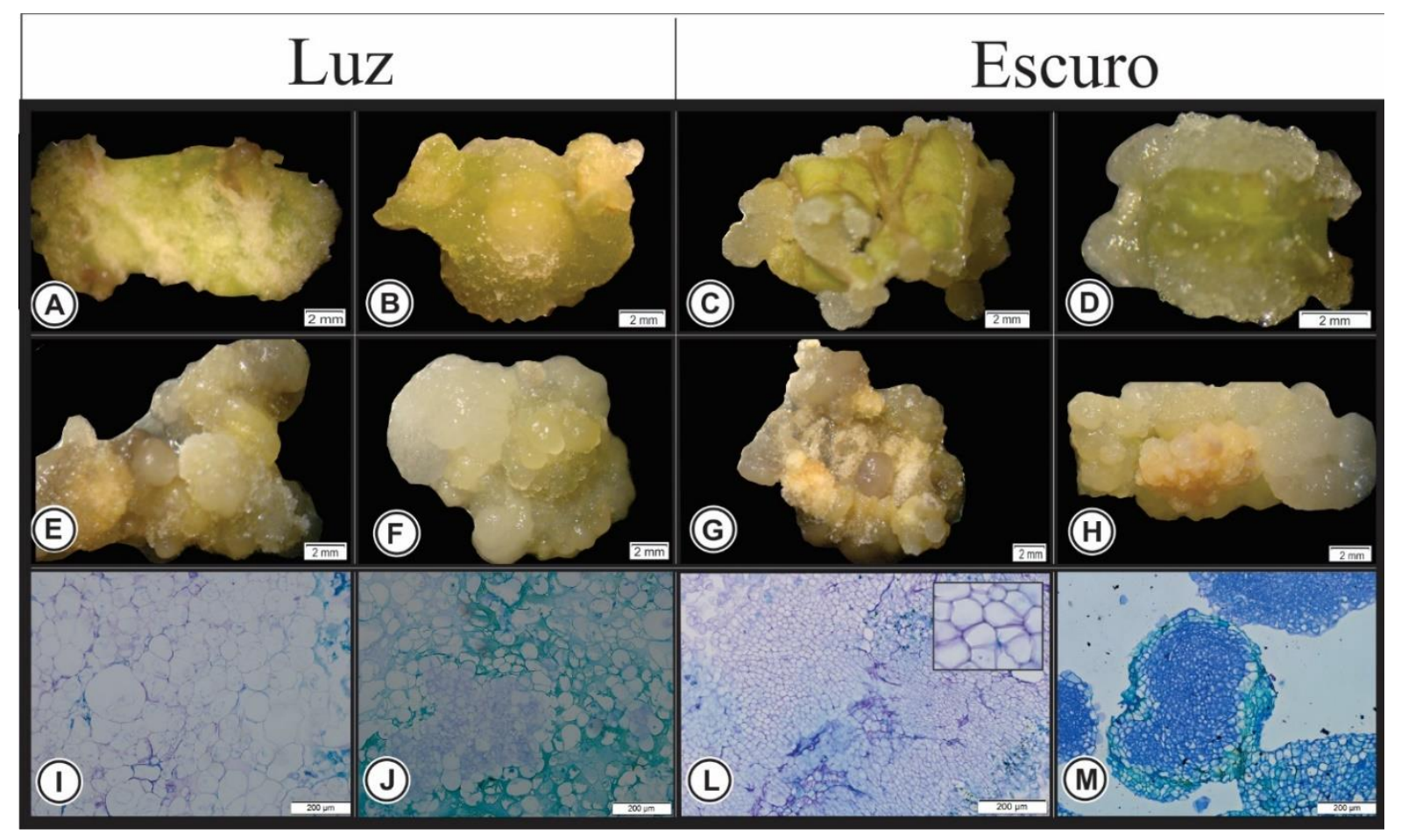

Figura 12: Análise morfológica e anatômica de calos de pinhão-manso (Jatropha curcas L.) obtidos a partir de folhas cotiledonares e hipocótilos cultivados na luz ou no escuro em meio de MS, suplementado com $200 \mu \mathrm{M}$ de picloram. A - D: explantes cultivados por 30 dias. E-H: explantes cultivados por 60 dias. I e L: Anatomia de calos de folhas cotiledonares. J e M: Anatomia de calos de hipocótilos.

Quando a combinação entre os reguladores 2,4-D e cinetina $(200 \mu \mathrm{M}$ e $50 \mu \mathrm{m}$, respectivamente) foi avaliada, verificou-se a formação de calos compactos, semi-compactos e friáveis de coloração que variou de verde-clara a translúcida, especialmente naqueles cultivados por 30 dias, independentemente da condição de luz ou escuro (Figura 13 A-D). Já aos 60 dias, calos compactos, incluindo os com formações multigranulares e globulares, de cor creme foram observados, especialmente de calos do hipocótilo, em ambas as condições de cultivo, embora em folhas cotiledonares cultivadas no escuro essas estruturas, em menor ocorrência, também tenham sido observadas (Figura $13 \mathrm{E}-\mathrm{H}$ ). Nesse tratamento foram observadas diversas formações do tipo embriogênicas, incluindo estruturas semelhantes a pró-embriões tardios, especialmente nas regiões periféricas dos calos do hipocótilo formados sob condições de luminosidade (Figura 13 I-M). 


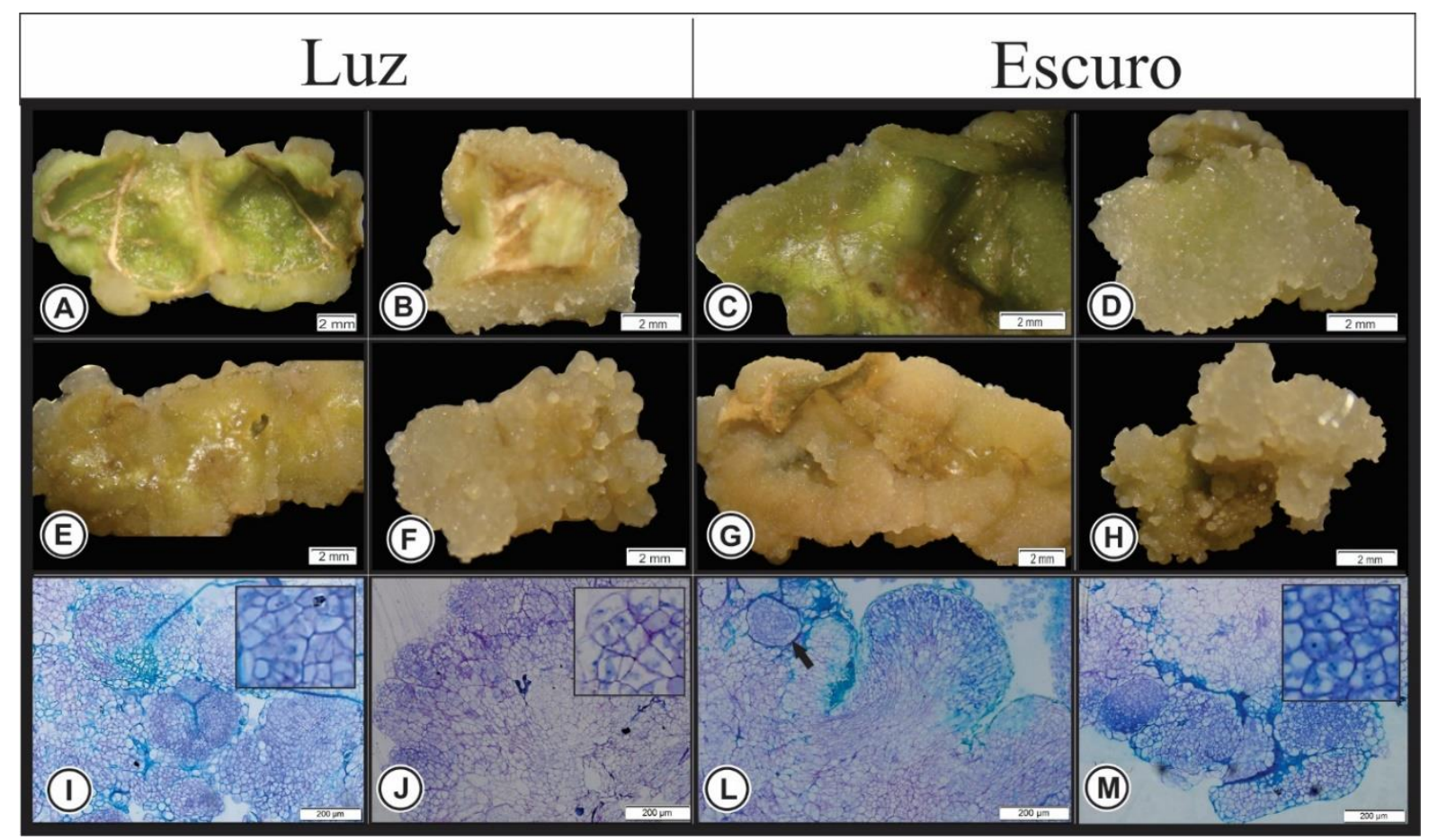

Figura 13: Análise morfológica e anatômica de calos de pinhão-manso (Jatropha curcas L.) obtidos a partir de folhas cotiledonares e hipocótilos cultivados na luz ou no escuro em meio de MS, suplementado com $200 \mu \mathrm{M}$ de 2,4-D e $50 \mu \mathrm{M}$ de cinetina. A - D: explantes cultivados por 30 dias. E-H: explantes cultivados por 60 dias. I e L: Anatomia de calos de folhas cotiledonares. J e M: Anatomia de calos de hipocótilos.

A embriogênese somática pode ser descrita como o processo pelo qual células somáticas desenvolvem estruturas semelhantes a embriões zigóticos, por meio de uma sequência ordenada de estádios embriogênicos característicos, sem ocorrência de fusão dos gametas (ZIMMERMAN, 1993, GUERRA et al., 1999; JIMÉNEZ, 2001). Esse processo in vitro apresenta dois padrões básicos de desenvolvimento de embriões: a embriogênese somática direta, na qual os embriões somáticos originam-se diretamente de tecidos matrizes, sem a formação de estádios intermediários de calos, e a embriogênese indireta, na qual os embriões se formam a partir de um calo. Em ambos os padrões, o embrião somático segue a mesma sequência de desenvolvimento do zigótico, ou seja, a passagem pelos estádios globular, cordiforme, torpedo e cotiledonar (WILLIAMS e MAHESWARAN, 1986; VON ARNOLD et al., 2002).

Para a identificação de embriogênese somática pode-se usar aspectos morfogênicos dos calos. Em modelos diretos, a primeira expressão morfogênica é o surgimento de estruturas globulares brancas e/ou translúcidas, que correspondem a embriões somáticos em estádio globular. Já em modelos indiretos, inicialmente há a diferenciação de calos e o surgimento neste de setores geralmente friáveis, normalmente brancos e/ou translúcidos, convencionalmente 
designados de massas ou complexos celulares pró-embriogênicos, os quais se dividem para formar pré-embriões somáticos. Esses aglomerados celulares capazes de produzir embriões somáticos possuem células de tamanho reduzido e citoplasma denso como principal característica (FEHÉR et al., 2003; XU e HUANG, 2008).

As auxinas 2,4-D e picloram têm sido investigadas com frequência como indutoras de embriogênese somática. A formação direta de embriões somáticos em Paspalum scrobiculatum ocorreu com a utilização de altos níveis de picloram, isoladamente ou em combinação com cinetina (KAUR e KOTHARI, 2004). Essa auxina também foi efetiva na obtenção de embriogênese somática repetitiva em Arachis hypogaea (LITTLE et al., 2000). O 2,4-D, considerado como a principal auxina de indução da embriogênese somática, também pode ser requerida em altas concentrações e/ou por longos períodos para iniciar a sequência de eventos que desencadeiam a embriogênese somática (FEHER et al., 2003). Em pinhão-manso, Nhut et al. (2013) também obtiveram sucesso na indução de calos a partir de folhas utilizando o 2,4-D.

Nos tratamentos onde se utilizou $200 \mu \mathrm{M}$ de picloram e $50 \mu \mathrm{M}$ de cinetina verificou-se apenas a formação de calos tipicamente esponjosos, de textura friável a semi-compactos, sem nenhum aspecto aparente e nem anatômico de se tratarem de formações embriogênicas (Figura $14 \mathrm{~A}-\mathrm{M})$.

Na maior concentração de auxina $(400 \mu \mathrm{M})$, explantes cultivados em presença de 2,4D apresentaram, de maneira geral, após 30 dias, calos que variaram do semi-compactos até os friáveis, de coloração esbranquiçadas e translúcida, incluindo os esverdeados, em ambos os tipos de propágulos utilizados, tanto na luz como no escuro (Figura 15 A-D). Já aos 60 dias, calos originários de hipocótilos apresentaram-se do tipo compacto e semi-compacto, inclusive com formações granulares, os quais foram preferencialmente de coloração creme, tanto quando cultivados na luz como no escuro. Nestas condições calos de folhas cotiledonares seguiram praticamente o mesmo padrão daqueles calos formados aos 30 dias, embora com maior volume aparente de calos formados (Figura $15 \mathrm{E}-\mathrm{H}$ ). Anatomicamente, os calos das folhas cotiledonares cultivados na luz apresentaram-se constituídos preferencialmente por células parenquimáticas e sem uma organização aparente. Já em calos de hipocótilos cultivados na luz foi possível observar células aparentemente maiores, com citoplasma mais denso e paredes celulares mais finas, indicando possíveis regiões de células meristemáticas (Figura 15 I e J). 


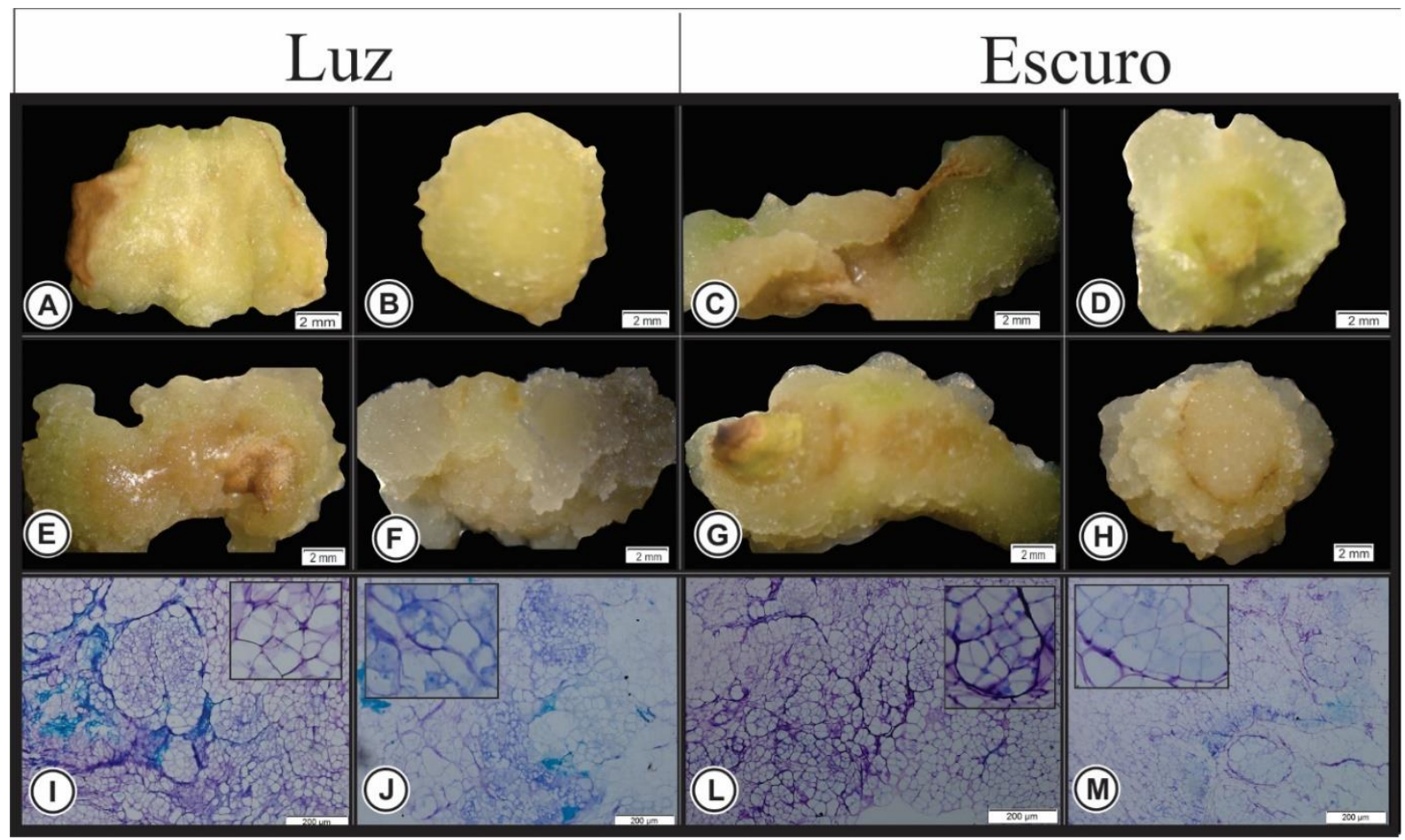

Figura 14: Análise morfológica e anatômica de calos de pinhão-manso (Jatropha curcas L.) obtidos a partir de folhas cotiledonares e hipocótilos cultivados na luz ou no escuro em meio de MS, suplementado com $200 \mu \mathrm{M}$ de picloram e $50 \mu \mathrm{M}$ de cinetina. A - D: explantes cultivados por 30 dias. E-H: explantes cultivados por 60 dias. I e L: Anatomia de calos de folhas cotiledonares. J e M: Anatomia de calos de hipocótilos.

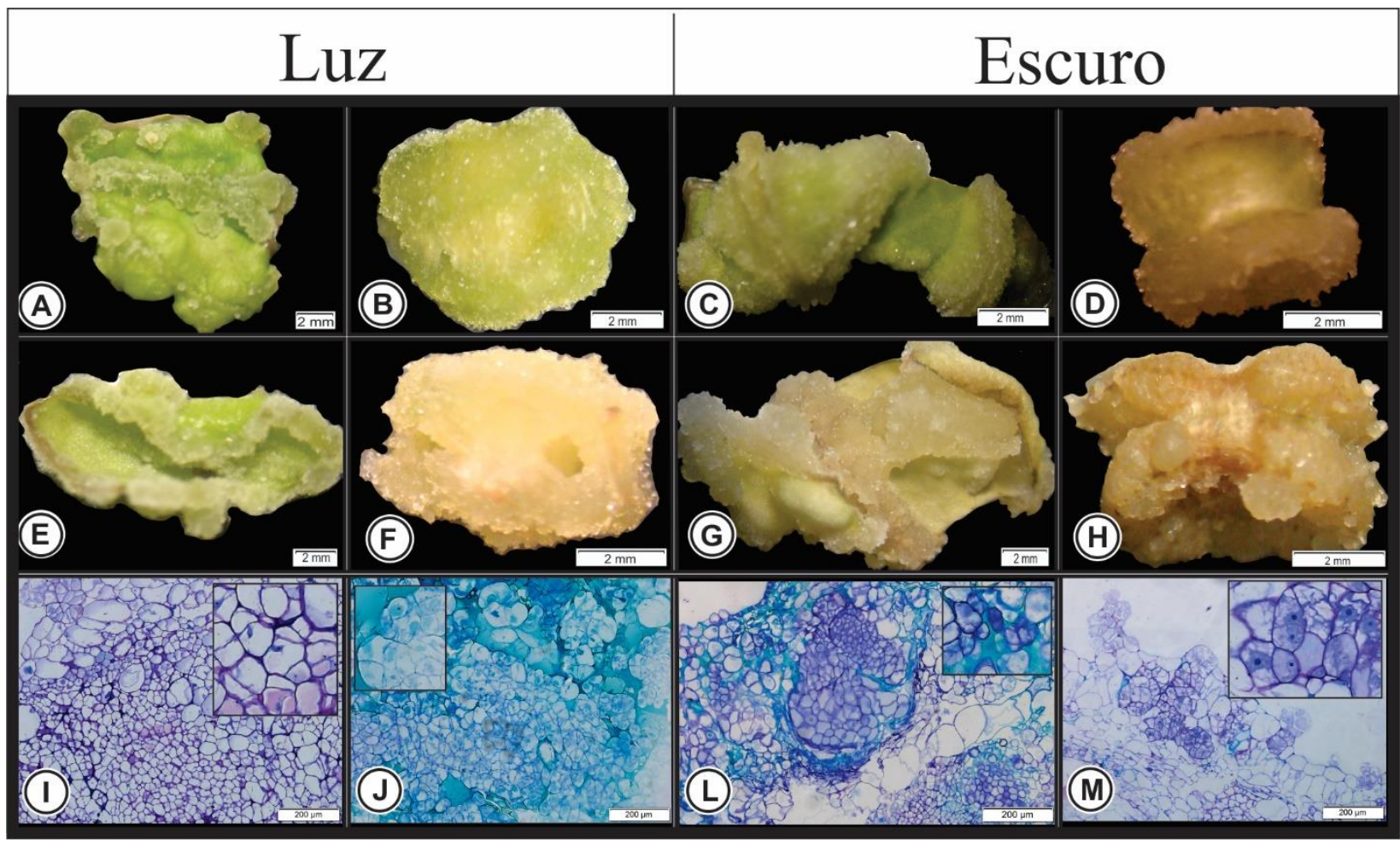

Figura 15: Análise morfológica e anatômica de calos de pinhão-manso (Jatropha curcas L.) obtidos a partir de folhas cotiledonares e hipocótilos cultivados na luz ou no escuro em meio de MS, suplementado com $400 \mu \mathrm{M}$ de 2,4-D. A - D: explantes cultivados por 30 dias. E-H: explantes cultivados por 60 dias. I e L: Anatomia de calos de folhas cotiledonares. J e M: Anatomia de calos de hipocótilos. 
Já nos calos dos explantes de folhas cotiledonares cultivadas no escuro, entre células parenquimáticas de diversos tamanhos e sem uma organização aparente foi possível observar uma grande região de células com citoplasma denso, núcleo evidente, indicando uma área meristemática com potencial embriogênico, ocorrência também evidenciada em calos formados a partir do hipocótilo (Figura 15 L e M).

Nos tratamentos com $400 \mu \mathrm{M}$ de picloram verificaram-se estruturas aparentemente interessantes apenas em calos de hipocótilos, especialmente os obtidos do cultivo no escuro (Figura 16). Na análise anatômica destes calos, classificados como sendo de consistência compacta e semi-compacta, de coloração creme, observou-se pequenas regiões de células meristemáticas organizadas de forma globular, dando indícios de se tratarem de regiões com proembriões, sendo que nas demais formações, não foram observadas estruturas embriogênicas (Figura $16 \mathrm{I}-\mathrm{M})$.

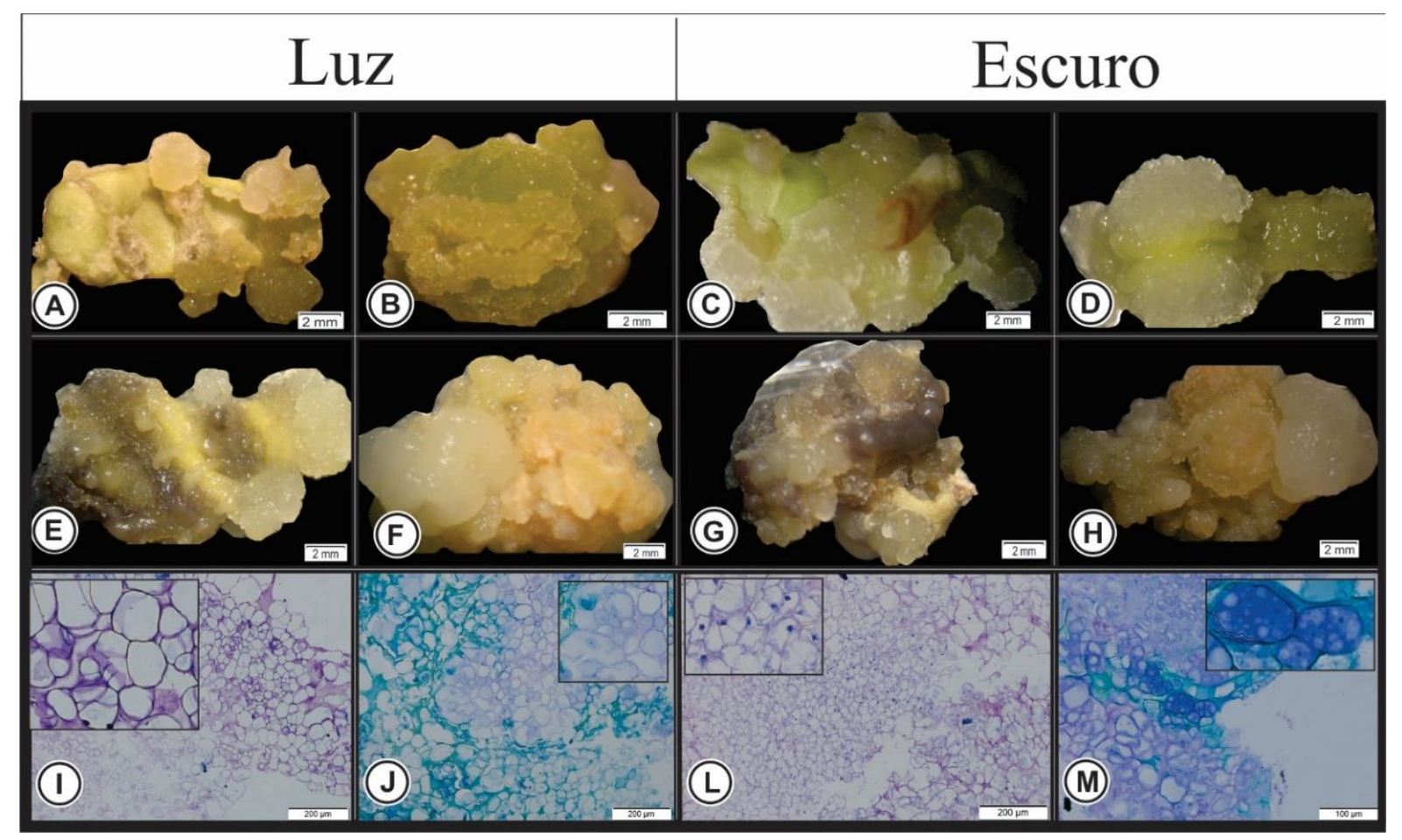

Figura 16: Análise morfológica e anatômica de calos de pinhão-manso (Jatropha curcas L.) obtidos a partir de folhas cotiledonares e hipocótilos cultivados na luz ou no escuro em meio de MS, suplementado com $400 \mu \mathrm{M}$ de picloram. A - D: explantes cultivados por 30 dias. E-H: explantes cultivados por 60 dias. I e L: Anatomia de calos de folhas cotiledonares. J e M: Anatomia de calos de hipocótilos.

Os tratamentos onde se utilizaram meios com $400 \mu \mathrm{M}$ de $2,4-\mathrm{D}$ e $50 \mu \mathrm{M}$ de cinetina podem ser observados na Figura 17. De maneira geral, calos compactos e semi-compactos, de coloração esbranquiçada, esverdeada e translúcida, após 30 dias foram observados. Já aos 60 dias de cultivo, a coloração observada nos calos foi predominantemente creme, com calos do 
hipocótilo apresentando formações multigranulares, algumas com características globulares, aparentes por praticamente toda a superfície do explante. Anatomicamente, calos formados a partir desse tratamento, a partir de folhas cotiledonares, apresentaram uma formação de calos parenquimáticos de aspectos não embriogênico. Entretanto, nos calos formados a partir de hipocótilos cultivados no escuro foi possível observar calos com pequenas regiões de células com citoplasma denso, independentes do calo principal, com formatos de estruturas globulares e, aparente conjunto de células de suspensor, sugerindo tratar-se de possíveis embriões globulares sendo formados (Figura $17 \mathrm{~J}$ e M).

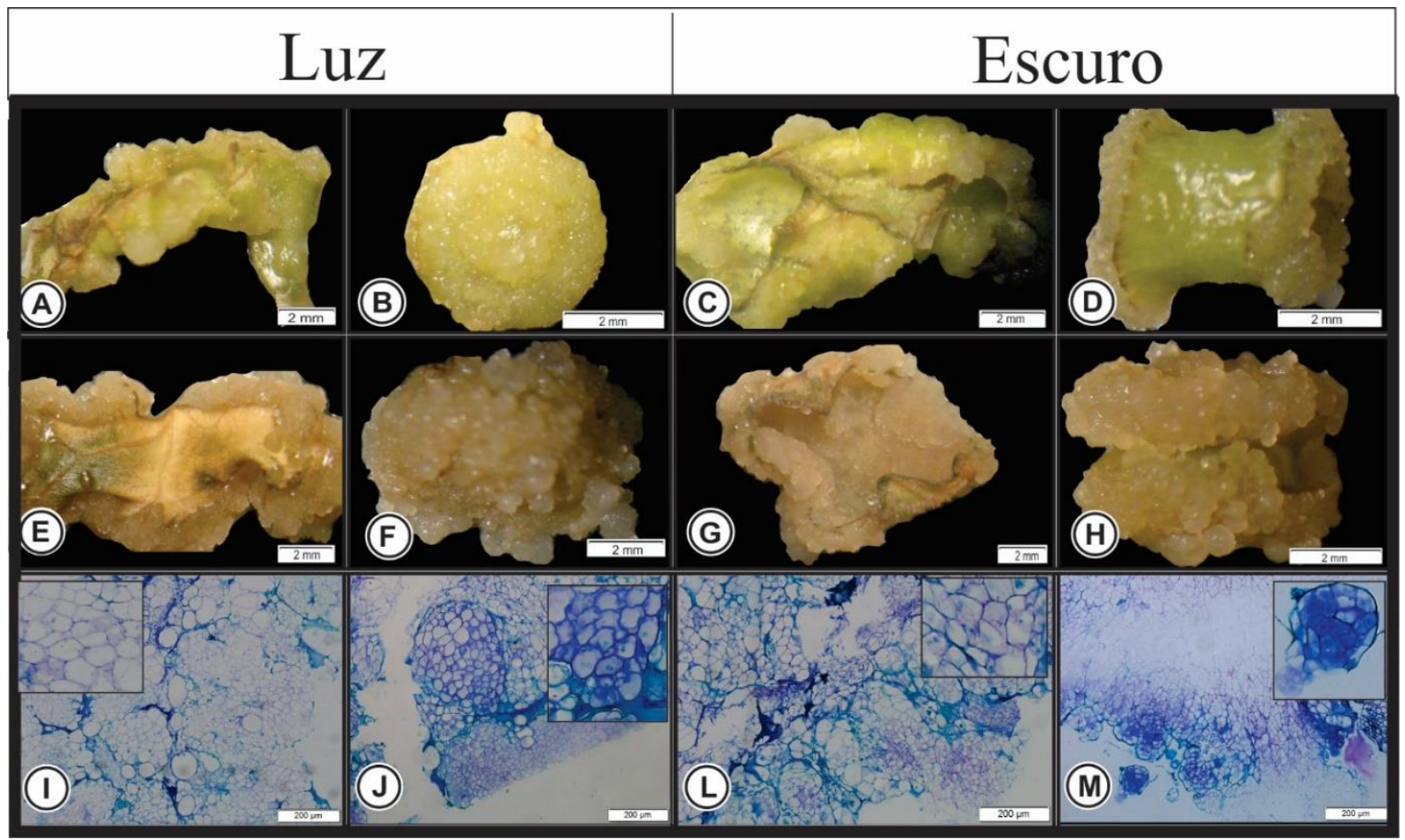

Figura 17: Análise morfológica e anatômica de calos de pinhão-manso (Jatropha curcas L.) obtidos a partir de folhas cotiledonares e hipocótilos cultivados na luz ou no escuro em meio de MS, suplementado com $400 \mu \mathrm{M}$ de 2,4-D e $50 \mu \mathrm{M}$ de cinetina. A - D: explantes cultivados por 30 dias. E-H: explantes cultivados por 60 dias. I e L: Anatomia de calos de folhas cotiledonares. J e M: Anatomia de calos de hipocótilos.

Já os tratamentos com $400 \mu \mathrm{M}$ de picloram combinado com $50 \mu \mathrm{M}$ de cinetina também mostraram a formação de diversas regiões com células meristemáticas em organização semelhantes a proembriões, principalmente em explantes de hipocótilos cultivadas na luz e escuro, e em folhas cotiledonares cultivadas no escuro (Figura 18). A textura geral dos calos foi de compacta a semi-compacta, com coloração que variou do transparente ao claroamarelado 


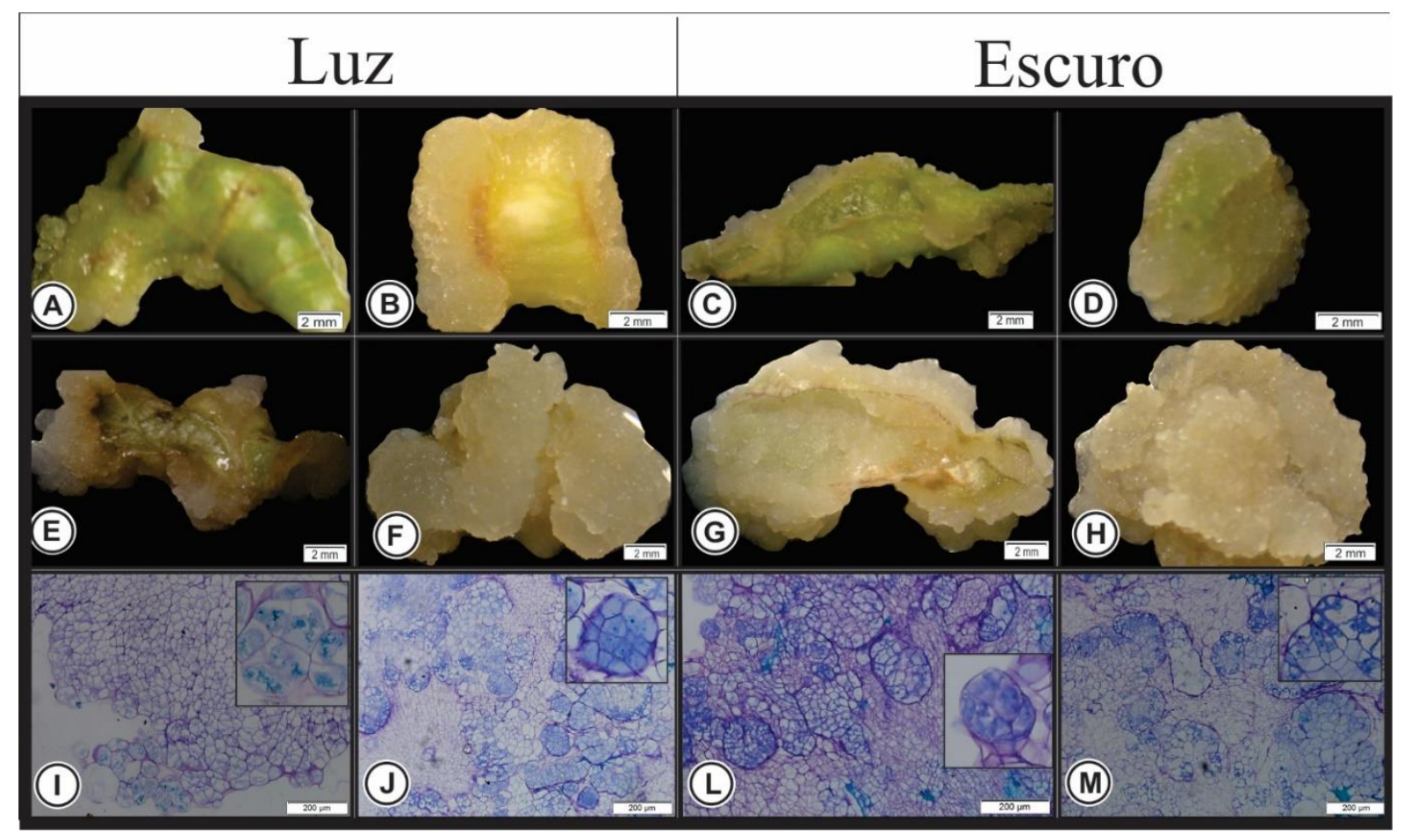

Figura 18: Análise morfológica e anatômica de calos de pinhão-manso (Jatropha curcas L.) obtidos a partir de folhas cotiledonares e hipocótilos cultivados na luz ou no escuro em meio de MS, suplementado com $400 \mu \mathrm{M}$ de picloram e $50 \mu \mathrm{M}$ de cinetina. A - D: explantes cultivados por 30 dias. E-H: explantes cultivados por 30 dias. I e L: Anatomia de calos de folhas cotiledonares. J e M: Anatomia de calos de hipocótilos. 


\section{CONCLUSÕES}

Nas condições que o experimento foi desenvolvido, é possível concluir que:

- Explantes de pinhão-manso, constituídos por hipocótilo e folhas cotiledonares de plantas jovens cultivadas in vitro são responsivos a indução de calos;

- Explantes de hipocótilo apresentam a formação de calos brancos friáveis, mesmo sem a presença de regulador de crescimento no meio de cultura;

- As auxinas 2,4-D e o picloram se mostram eficientes na indução de calos em explantes provenientes de hipocótilos e folhas cotiledonares;

- O picloram apresenta as maiores percentagens de explantes contendo calos nas condições de cultivo de luz e escuro e nos tempos de 30 e 60 dias, tanto em hipocótilo quanto de folhas cotilédones.

- O tratamento contento apenas cinetina promove a formação de calos friáveis em folhas cotiledonares e calos friáveis e semi-compactos em explantes de hipocótilo;

- O 2,4-D é mais eficiente na formação de calos compactos com aspecto globular, enquanto o picloram na indução de calos semi-compactos e friáveis e de grande volume;

- As concentrações de 200 e $400 \mu \mathrm{M}$ de picloram e 2,4-D são eficientes na indução de calos com características embriogênicas em hipocótilos e folhas cotiledonares cultivados, preferencialmente, no escuro, e;

- O cultivo de explantes formados por hipocótilos e folhas cotiledonares de pinhãomanso no escuro promove a indução de calos com características embriogênicas do que em condições de luz. 


\section{REFERÊNCIAS BIBLIOGRÁFICAS}

ACHTEN, W. M., MAES, W., AERTS, R., VERCHOT, L., TRABUCCO, A., MATHIJS, E MUYS, B. Jatropha: from global hype to local opportunity. Journal of Arid Environments, v. 74 , n. 1 , p. $164-165,2010$

ATTAYA, A.S., D. GEELEN \& A.E.H. BELAL. Progress in Jatropha curcas tissue culture. American-Eurasian Journal of Sustainable Agriculture. v. 6, p. 6-13. 2012.

BALASUBRAMANYA, S., RAJANNA, L. E ANURADHA, M. Effect of plant growth regulators on morphogenesis and forskolin production in Plectranthus barbatus Andrews. In Vitro Cellular \& Developmental Biology - Plant, v.48, p.208-215, 2012.

CHIANGMAI, P.N., POOTAENG-ON, Y., MEETUM, P., KAMKAJON, K., YUIAM, W., RUNGPHAN, N., NINKAEW, P. Regeneration of Adventitious Shoots from Callus and Leaf Explants in Jatropha curcas L. 'Phetchaburi'. Silpakorn University Science and Technology Journal, n. 9, v. 1, p. 28-39, 2015.

DEORE, A.C., JOHNSON, T. S. High-frequency plant regeneration from leaf-disc cultures of Jatropha curcas L.: an important biodiesel plant. Plant Biotechnology Reports, n. 2, p. 7 11, 2008.

EVERT, R.F. Meristemas e diferenciação. In: Anatomia das Plantas de Esau. Blucher: $3^{\mathrm{a}}$ Ed. 2013.

FEHER, A., PASTERNAK, T. P. e DUDITS, D. Transition of somatic plant cells to an embryogenic state. Plant Cell, Tissue and Organ Culture, v. 74, n. 3, p. 201-228, 2003.

FRANK, M., GUIVARC'H, A., KRUPKOVA, E., LORENZ-MEYER, I., CHRIQUI, D., e SCHMÜLLING, T. TUMOROUS SHOOT DEVELOPMENT (TSD) genes are required for coordinated plant shoot development. The Plant Journal, v. 29, n. 1, p. 73-85, 2002.

GEORGE, E.F. Plant Propagation by Tissue Culture. 2. Ed., Edington: Exegetics, 1361 p. Part 2: In Practice. 1996.

GUBITZ GM, MITTELBACH M, TRABI M. Exploitation of the tropical oil seed plant Jatropha curcas L. Bioresour Technol 67:73-82. 1999.

GUERRA, M. P.; TORRES, A. C.; TEIXEIRA, J. B. Embriogênese somática e sementes sintéticas. In: TORRES, A. C.; CALDAS, L. S.; BUSO, J. A. (Ed.). Cultura de tecidos e transformação genética de plantas. Brasília: Embrapa-SPI/Embrapa-CNPH, v. 2. p. 533-568. 1999.

HELLER, J. Physic nut, Jatropha curcas L. In Promoting the conservation and use of underutilized and neglected crops. No 1, pp 66. Rome: International Plant Genetics Resource Institute. 1996.

IKEUCHI, M., SUGIMOTO, K., E IWASE, A. Plant callus: mechanisms of induction and repression. The Plant Cell, v. 25, n.1, p.3159-3173, 2013. 
JHA TB, MUKHERJEE P, DATTA MM. Somatic embryogenesis in Jatropha curcas L., an important biofuel plant. Plant Biotechnology Reports, v.1, p.135-140, 2007.

JIMÉNEZ, V. M. Regulation of in vitro somatic embryogenesis with emphasis on the role of endogenous hormones. Revista Brasileira de Fisiologia Vegetal, v.13, n.2, p.196-223, 2001.

KARNOVSKY, M. J. A formaldehyde-glutaraldehyde fixative of high osmolality for use in eletron microscopy. Journal of Cell Biology, New York, v. 27, n. 15, p. 137- 138, 1965.

KAUR, P.; KOTHARI, S. L. In vitro culture of kodo millet: influence of 2,4-D and picloram in combination with Kinetin on callus initiation and regeneration. Plant Cell, Tissue and Organ Culture, v.77, p.73-79, 2004.

LITTLE, E. L.; MAGBANUA, Z. V.; PARROTT, W. A. A protocol for repetitive somatic embryogenesis from mature peanut epicotyls. Plant Cell Reports, v.19, p.351-357, 2000.

MUKHERJEE, P., VARSHNEY, A., JOHNSON, T.S., e JHA, T.B. Jatropha curcas: A Review on Biotechnological Status and Challenges, Plant Biotechnology Reports. 2011.

MURASHIGE, T. \& SKOOG, F. A revised medium for rapid growth and biossays with tobacco tissue cultures. Physiol. Plant., 15: 473-497, 1962.

NARAYANASWAMY, S. Regeneration of plants from tissue cultures. In: Applied and fundamental aspects of plant cell, tissue and organ culture. (Ed.): Y.P.S. Bajaj, Springer-Verlag Berlin, Heidelberg, New York, pp.179-248. 1977.

NHUT, D.T., GIAP, D.D., VINH, B.V.T., LOAN, N.T.K., HUY, N.P., HAI, N.T., CHIEN, H.X., TUAN, T.T. E DU, T.X. Thin cell layer technology in micropropagation of Jatropha curcas L. Biotechnology of Neglected and Underutilized Crops, p. 33 - 42, 2013.

O`BRIEN, T. P. \& MCCULLY, M. E. The study of plant structure principles and selected methods. Melbourne, Termarcarphi Pty Ltd., 1981.

OPENSHAW, K. A review of Jatropha curcas: an oil plant of unfulfilled promise. Biomass e Bioenergy, n. 19, p. 1-15, 2000.

PARAWIRA, W. Biodiesel production from Jatropha curcas: A review. Scientific Research and Essays, v. 5, n. 14, p. 1796-1808, 2010.

REIS, I.N.R.S., LAMEIRA, O.A., CORDEIRO, I.M.C.C. Efeito do 2,4-D na indução de calos in vitro de Paricá (Schizolobium parahyba var. amazonicum (Huber ex Ducke) Barneby). Revista Brasileira de Biociências, Porto Alegre, v. 5, supl. 2, p. 498-500, 2007.

SANTOS, D.N., NUNES, C.F., SOARES, J.D.R., VALENTE, T.C.T., ALVES, E., LABORY, C.R.G. E PASQUAL, M. Cytological characterization of Jatropha curcas callus in different periods of cultivation. Crop Breeding and Applied Biotechnology, v. 13, p. 228-233, 2013.

SANTOS, M.R.A., FERREIRA, M.G.R., CARVALHO, S.M.S. Callus induction in Bertholletia excelsa immature seeds. Journal of Biotechnology and Biodiversity. v.4, n.4,p. 283-289, 2013. 
SATURNINO, H.M.; PACHECO, D.D.; KAKIDA, J.; TOMINAGA, N. e GONÇALVES, N.P. Cultura do pinhão-manso (Jatropha curcas L.). Informe Agropecuário, Belo Horizonte, p. 44$74,2005$.

SHUKLA, P., MAKWANA, V., BHATT, D., ROBIN, P. Efficient method for direct and indirect organogenesis in biofuel crop Jatropha curcas. International Journal of Pharma and Bio Sciences. v. 4, n. 1, p. 673 - 682. 2013.

SIANG, T. C., SOONG, S. T., E YIEN, A. T. S. Plant regeneration studies of Jatropha curcas using induced embryogenic callus from cotyledon explants. African Journal of Biotechnology, v. 11, n. 31, 2014.

SILVA, F. de A. S. e; AZEVEDO, C. A. V. de. Principal Components Analysis in the Software Assistat-Statistical Attendance. In: World congress on computers in agriculture, 7, Reno-NVUSA: American Society of Agricultural and Biological Engineers, 2009.

SOLÍS-RAMOS, L.Y., CARBALLO, L.M. E VALDEZ-MELARA, M. Establishment of cell suspension cultures of two Costa Rican Jatropha species (Euphorbiaceae). Revista de

Biologia Tropical Journals collection, v. 61, n. 3, p. 1095-1107, 2013.

SOOMRO, R. e MEMON, R.A. Establishment of callus and suspension culture in Jatropha curcas. Pakistan Journal of Botany., v.39, n. 7, p. 2431-2441, 2007.

STEWARD, F.C., MAPES, M.O. e MEARS, K. Growth and organized development of cultured cells. II. Organization in cultures grown from freely suspended cells. American Journal of Botany, p. 705-708, 1958.

SUJATHA, M. e DHINGRA, M. Rapid plant regeneration from various explants of Jatropha integerrima. Plant Cell Tissue Organ Cult. n. 35, p.293-296. 1993.

SUJATHA, M., MAKKAR, H.P.S., BECKER, K. Shoot bud proliferation from axillary nodes and leaf sections of non-toxic Jatropha curcas L. Plant Growth Regulation, n. 47, p.83-90, 2005.

SUJATHA, M., MUKTA, N. Morphogenesis and plant regeneration from tissue cultures of Jatropha curcas. Plant Cell, Tissue and Organ Culture (Historical Archive) v. 44, p. 135141. 1996.

SWARUP R. Biotechnological interventions to improve Jatropha seeds and oil quality. SAARC Oils \& Fats Today, August, p. 39-41 Tsugawa H. 2004.

VARSHNEY A, JOHNSON TS. Efficient plant regeneration from immature embryo cultures of Jatropha curcas, a biodiesel plant. Plant Biotechnology Reports, v. 4, p. 139-148, 2010.

VON ARNOLD, S. Developmental pathways of somatic embryogenesis. Plant Cell, Tissue and Organ Culture, v. 69, n. 3, p. 233-249, 2002.

WEI, Q., LU, W.-D. LIAO, Y., PAN, S. L. XU, Y., TANG, L., AND CHEN, F. Plant regeneration from epicotyl explant of Jatropha curcas. Journal of Plant Physiology and Molecular Biology. v. 30, p. 475-478. 2004. 
WEIDA, L., QIM, W., LIN TANG, FANG Y, FANG C. Induction of callus from Jatropha curcas and its rapid propagation. Ying Yong Yu Huan Jing Sheng Wu Xue Bao, n. 9, p. 127$130,2003$.

WILLIAMS, E. G. e MAHESWARAN, G. Somatic embryogenesis: factors influencing coordinated behaviour of cells as an embryogenic group. Annals of Botany, v. 57, n. 4, p. 443$462,1986$.

WINKLER, E., GÜBITZ, G. M., FOIDL, N., STAUBMANN, R., AND STEINER, W. Use of enzymes for oil extraction from Jatropha curcas seeds. In Proceeding "Jatropha curcas" (Gübitz, G. M., Mittelbach, M., and Trabi, M. eds.) Managua, Nicaragua. 1997.

XU, C.; HUANG, B. Root proteomic responses to heat stress in two Agrostis grass species contrasting in heat tolerance. Journal of Experimental Botany, New Brunswick, v.59, n. 15, p. 4248-4294, 2008.

YING LIU, XIN TONG, WENKAI HUI, TONG LIU, XIAOYANG CHEN, JING LI, CHUXIONG ZHUANG, YUESHENG YANG, ZHENLAN LIU. Efficient culture protocol for plant regeneration from petiole explants of physiologically mature trees of Jatropha curcas L. Biotechnology \& Biotechnological Equipment, v. 29, n. 5, p. 479-488, 2015.

ZIMMERMAN, J. L. Somatic embryogenesis: a model for early development in higher plants. The Plant Cell, v. 5, n. 10, p. 1411, 1993. 